UNIVERSIDADE DE SÃO PAULO

FACULDADE DE FILOSOFIA, LETRAS E CIÊNCIAS HUMANAS

DEPARTAMENTO DE FILOSOFIA

PROGRAMA DE PÓS-GRADUAÇÃO EM FILOSOFIA

\title{
A AMPLIAÇÃO DO ESPAÇO DA MORAL NO \\ UTILITARISMO DE JOHN STUART MILL: UMA \\ COMPARAÇÃO COM A MORAL DO UTILITARISMO DE BENTHAM
}

Maria Cristina Longo Cardoso Dias 
Maria Cristina Longo Cardoso Dias

\author{
A AMPLIAÇÃO DO ESPAÇO DA MORAL NO \\ UTILITARISMO DE JOHN STUART MILL: UMA \\ COMPARAÇÃO COM A MORAL DO UTILITARISMO DE \\ BENTHAM
}

Versão corrigida da tese apresentada ao Programa de Pós-Graduação da Faculdade de Filosofia, Letras e Ciências Humanas da Universidade de São Paulo, para a obtenção de título de Doutor em Filosofia.

De Acordo,

São Paulo 
Aos meus pais Daguzan e Wanda e à minha avó

Emília, in memoriam. 


\section{AGRADECIMENTOS}

Ao meu orientador professor Dr. José Raymundo Novaes Chiappin pelos ensinamentos filosóficos, metodológicos e de ética utilitarista efetuados ao longo deste trabalho.

Ao meu orientador no exterior, John Maria Skorupski, por conduzir minha pesquisa e indicação bibliográfica sobre a filosofia de John Stuart Mill e de seu utilitarismo, durante minha visita à Universidade de St Andrews.

Aos professores Marco Antônio de Ávila Zingano e Maria das Graças de Souza pelos cursos de Ética, pelos ensinamentos sobre o rigor filosófico, pela maneira inteligente e clara de conduzir suas interpretações filosóficas.

A todos os amigos do Grupo das Luzes Britânicas.

Aos professores Carlos Alberto de Moura, José Carlos Estêvão e Franklin Leopoldo e Silva pelos cursos rigorosos de filosofia que fizeram parte da minha formação.

Ao professor Caetano Ernesto Plastino pelos cursos de filosofia e por acompanhar-me, ainda que indiretamente, desde a minha entrada no curso de filosofia. 
Ao Departamento de Filosofia da FFLCH/USP pelo rigor acadêmico que mantém na maneira como ensina filosofia e aos amigos que lá fiz.

Às queridas Geni, Luciana, Maria Helena, Marie e Verônica.

Ao professor Iram Jácome Rodrigues por seus brilhantes cursos de Introdução às Ciências Sociais oferecidos na FEA.

À professora Leda Maria Paulanni por apresentar-me à filosofia, na FEA, através da leitura do Capital.

À professora Silvia Maria Schor, por despertar-me para o interesse de entender os fundamentos do utilitarismo.

Aos meus pais pelo apoio em tudo que realizei na minha vida.

Aos meus queridos amigos Daniela Mello, Guilherme e Rafael Versolato pelo apoio direto no decorrer de todo este trabalho.

A todos os meus queridos amigos dos Cadernos de Ética e Filosofia Política, em especial a Frederico Diehl, Thana Mara de Souza, Cecília Almeida, Patrícia Aranovitch, Thomaz Kawauche, Marcos Balieiro e tantos outros membros recentes dos cadernos. 
À minha imensa família paulistana e do cerrado, sempre pronta a apoiar qualquer contingência eventual.

Aos meus irmãos Fernando e Carlos.

Aos queridos amigos que fiz no Reino Unido: Scott Brooks, Martin Sticker, Gil Sagi, Colin Caret, Michael De, Emma Duckworth, André Grahle e Fiona Howe.

Ao CNPQ que me forneceu condições materiais para a minha dedicação exclusiva à esta tese. 


\section{RESUMO}

Dias, C.L.C.M. A Ampliação do Espaço da Moral no Utilitarismo de John Stuart Mill: uma Comparação com a moral do Utilitarismo de Bentham, $318 \mathrm{f}$. Tese (Doutorado) - Faculdade de Filosofia, Letras, e Ciências Humanas. Departamento de Filosofia. São Paulo: Universidade de São Paulo, 2011.

Este trabalho tem por objetivo provar que há mais espaço para elaboração de regras morais no utilitarismo de Mill quando comparado ao utilitarismo de Bentham. Para que esta tese seja provada é necessário comprovar que a concepção de natureza humana do indivíduo teórico de Mill é mais complexa do que a concepção de natureza humana de Bentham, pois é a ciência da natureza humana que constitui o fundamento das prescrições da moralidade.

Esta tese provará que a natureza humana do indivíduo teórico de Bentham resume-se a uma natureza humana dotada, principalmente, de uma razão capaz de formular cálculos complexos entre prazer e dor (que inclui a intensidade, proximidade, longinquidade, etc) para decidir sobre a melhor ação (aquela que aponta para o prazer, no cômputo geral do balanço). Em outras palavras, um apelo ao primeiro princípio, ao princípio de utilidade é efetuado a cada ação, questionando as regras do costume e reduzindo o espaço da moral a apenas ao princípio de utilidade. Para Mill, ao contrário, a natureza humana é mais complexa. Ela é composta, de leis da mente ou leis psicológicas, da tese hedonista (que significa que os indivíduos buscam prazer e evitam a dor, assim como para Bentham) e subteses da tese hedonista, como o fato de que os indivíduos, por natureza, agem por hábito, possuem faculdades elevadas das quais derivam prazeres de qualidade superior e possuem a capacidade de se transformar ao longo do tempo. Essas características da natureza humana do indivíduo teórico de Mill permitem converter um princípio de utilidade mais complexo que prescreve que é correto buscar o prazer e fugir da dor como característica central, mas que ressalta que mais elementos precisam ser aventados para que se compreenda a busca do prazer ou a busca da felicidade. É precisamente quando a formulação do princípio de utilidade de Mill abre espaço para que mais elementos precisem ser expostos para que se entenda a busca do prazer ou a maximização da felicidade, que surge a possibilidade de elaboração de regras morais, preceitos ou princípios secundários que permitem que o agente guie-se no mundo prático. Em outras palavras, a natureza mais complexa do indivíduo teórico de Mill admite a 
elaboração de um princípio de utilidade mais complexo que dá margem à elaboração de uma moralidade também mais complexa, com mais regras morais (ainda que inicialmente embasadas em um cálculo de prazer) relativamente à moral de Bentham.

\section{PALAVRAS-CHAVE (6)}

Utilitarismo, Bentham, John Stuart Mill, Moral, Ética, Racionalidade. 


\begin{abstract}
Dias, C.L.C.M. The Ampliation of Morality Place on John Stuart Mill's Utilitarianism: A Comparison with Bentham's Utilitarian Morality, 318 f. Thesis (Doctoral) - Faculdade de Filosofia, Letras e Ciências Humanas. Departamento de Filosofia. Universidade de São Paulo, 2011.
\end{abstract}

This work aims to prove that there is more place for the elaboration of moral rules in Mill's utilitarianism when compared to Bentham's utilitarianism. To prove this thesis it is necessary that Mill's conception of human nature be more complex than Bentham's conception of human nature, given the fact that it is science of human nature which holds the foundation of morality.

This thesis will prove that human nature of Bentham's individuals is resumed to a human nature which main feature is an instrumental reason, able to formulate complex calculations between pleasure and pain (which includes intensity, proximity, duration, etc of the pleasures and pains) to decide about the best action (the one which decides for pleasure, once made the balance). In other words, an appeal to the first principle, to the principle of utility is done in each action, questioning customary rules and reducing morality to the principle of utility. For Mill, on the contrary, human nature is more complex. It consists of laws of mind or psychological laws, of hedonistic thesis (which means that individuals look for pleasure and avoid pain in the same sense as Bentham's individuals) and sub-thesis of hedonistic thesis, such as the fact that individuals act by habit, they have elevated faculties which derive pleasures of higher qualities and they hold the capacity of transforming themselves through time. Those human nature features of Mill's individuals permits to formulate a more complex principle of utility which determines that it is right to look for pleasure and right to avoid pain as the main feature, but many more elements need to be sustained in order to achieve a better understanding of happiness. It is precisely when the formulation of Mill's principle of utility opens room for more elements to explain the search of pleasure and the avoidance of pain or the maximization of happiness, that the possibility of formulation of moral rules becomes plausible. Secondary principles are necessary in Mill's system to be formulated, so the agent can guide himself in the practical world without an appeal to the first principle in each action. In other words, Mill's more complex individuals nature permits the elaboration of a more complex principle of utility which opens place for the elaboration 
of a more complex morality with more moral rules (even if, initially, those moral rules are grounded on a calculation between pleasure and pain) when compared to Bentham's morality.

\section{KEY-WORDS (6)}

Utilitarianism, Bentham, John Stuart Mill, Ethics, Morality, Rationality. 


\section{$\underline{\text { Índice }}$}

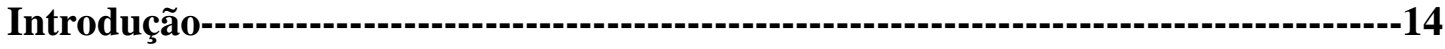

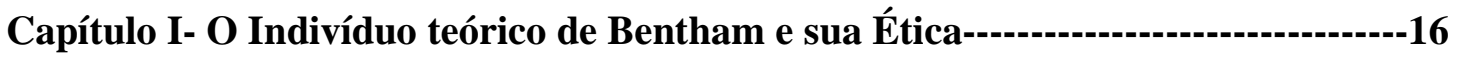

1 Uma visão geral do indivíduo e da ética de Bentham-----------------------------------16

2 Casos em que não cabe punir ---

3 A fronteira entre ética e legislação-------

\section{Capítulo II- Os Autores que mais influenciaram Mill no que diz respeito à Ética}

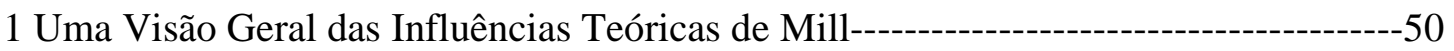

2 A concepção de Bentham: a rejeição parcial do utilitarismo de Bentham em relação ao

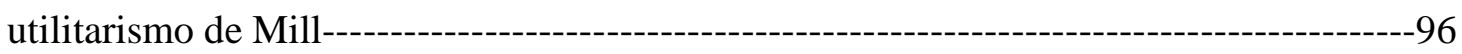

Capítulo III - O Modelo de Indivíduo teórico de Mill (outra natureza humana, novas características, novo princípio de utilidade, novo método que embasa a

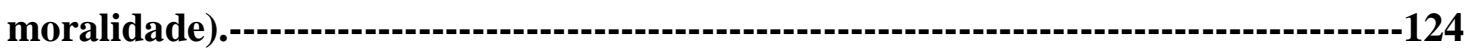

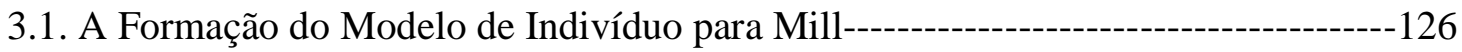

3.2. Que Existe uma Natureza Humana e que Ela Possui Certas Leis---------------------131

3.3 Um Componente da Natureza Humana: as Leis da Mente-------------------------134

3.4 Outro componente da natureza humana: a formação do caráter como dependente das

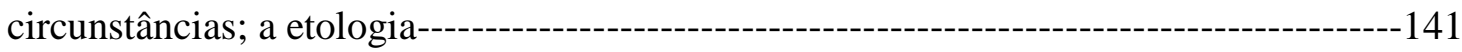

3.5 O método químico ou método experimental em Ciência Social-----------------------162

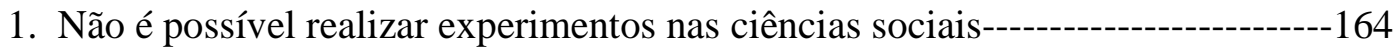

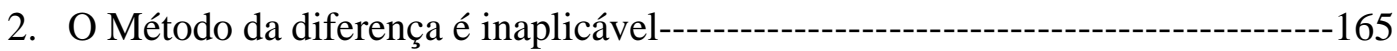

3. O método de acordo e de variações concomitantes são ditos inconclusivos, na

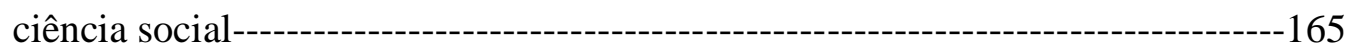

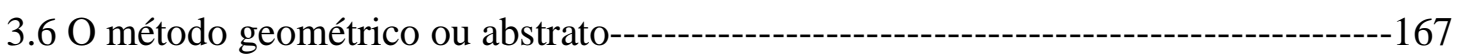

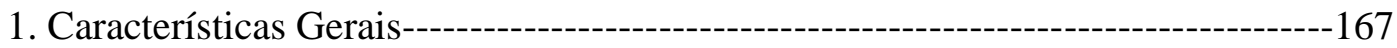

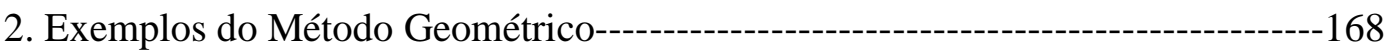

3.7 Método físico ou concreto dedutivo que Mill chama de método adequado dedutivo às Ciências Sociais- 


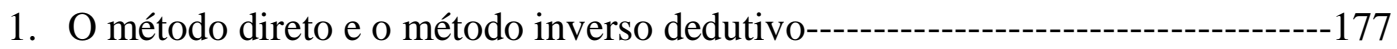

2. Dificuldades do Método Dedutivo Direto em Ciência Social---------------------180

3. A Economia Política como ciência social pode ser estudada a parte-------------183

4. Etologia Política ou a ciência do caráter nacional--------------------------------186

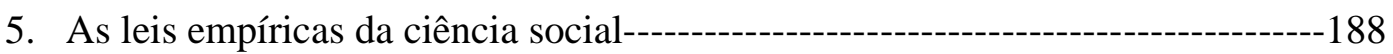

6. A maneira de verificar uma certa causa social em meio a um grande número de

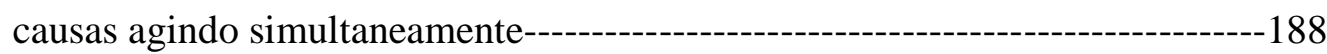

3.8 A seguir descreve-se o método dedutivo inverso ou o método histórico. Ou aquele que considera primeiro a experiência para depois comparar com as leis da natureza humana.

1. Distinção entre a ciência geral da sociedade e especiais pesquisas sociológicas 189

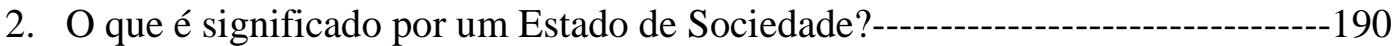

3. O progresso do homem e da sociedade $-190$

4. As leis da sucessão dos estados da sociedade só podem ser determinadas pelo

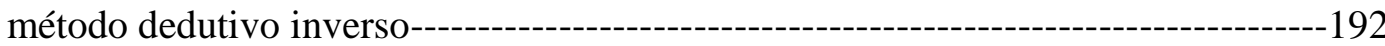

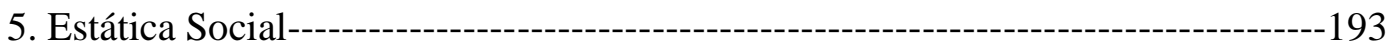

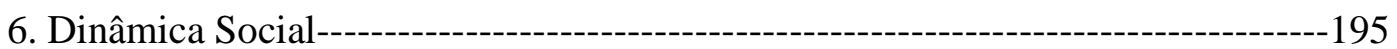

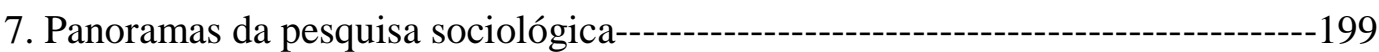

8. Afirma-se que a sujeição dos fatos históricos a leis uniformes é verificada ao rigor estatístico---------------------------------------------------------------------------------------201

9. A Sujeição dos fatos históricos a leis uniformes não implica a insignificância das causas morais------------------------------------------------------------------------------203

10. A sujeição dos fatos históricos a leis uniformes não implica a ineficácia do caráter dos indivíduos e dos atos do governo-------------------------------------------205

11.A importância histórica dos homens eminentes e da ação política dos governos esclarecidos $-206$

3.9 A Moralidade é uma arte que deve ser embasada em uma ciência---------207

1. A Moralidade não é uma ciência, mas uma Arte (dita preceitos)-----------------207 


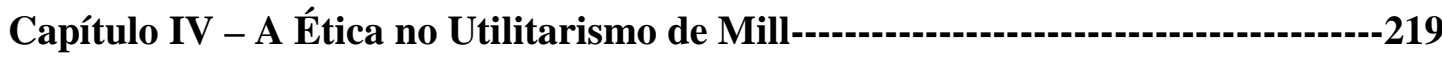

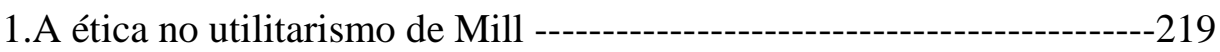

2 O Utilitarismo de Regra versus o Utilitarismo de Ato--------------------234

Capítulo V - A Ampliação do Espaço da Moral no Utilitarismo de Mill: uma

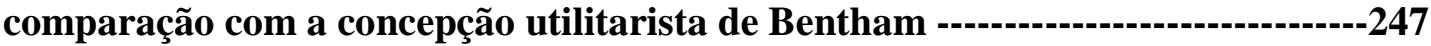

1 Bentham e sua Ética--------------------------------------------------------------247

2 Casos em que não cabe punir legalmente no sistema de Bentham---------259

3 O estabelecimento da fronteira entre a ética e a legislação, para Bentham, e uma Introdução à Ética de Mill-------------------------------------------------264

4 A Ética de Mill e uma comparação com a Ética e o indivíduo teórico de Bentham 274

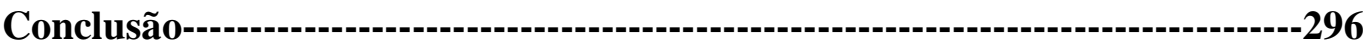

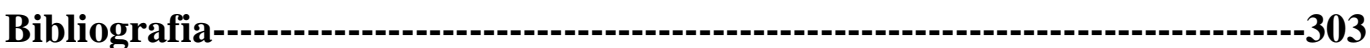




\section{$\underline{\text { Introdução }}$}

Este trabalho tem por objetivo provar uma tese, mas para além disso reconhece-se que a história de vida de um autor nunca vem separada de seu projeto intelectual e que esta história pode influenciar de maneira determinante a obra de um escritor, ainda mais quando se trata de um escritor filósofo que defende uma filosofia associacionista, empirista, como é o caso de John Stuart Mill. Em outras palavras, a história de vida do filósofo é fundamental para que se compreenda sua filosofia. Ademais, tem-se por objetivo, além de estimular a razão humana, neste trabalho, projeto de todos os trabalhos filosóficos, atingir a finalidade de tocar outros sentidos humanos, pois reconhece-se que um escrito torna-se mais completo quando atinge tal escopo, ainda que se entenda que este possa parecer um projeto um pouco ambicioso ${ }^{1}$.

No que concerne a uma leitura mais estrutural do texto, esta tese tem por objetivo efetuar uma comparação entre a concepção moral do utilitarismo de John Stuart Mill e a de Jeremy Bentham. Pretende-se mostrar que há mais espaço para a elaboração de regras morais no utilitarismo de John Stuart Mill quando comparado ao utilitarismo de Jeremy Bentham, uma vez que se sustentará que o utilitarismo de Bentham é um utilitarismo negativo no sentido moral, dado que a racionalidade do indivíduo teórico de Bentham é uma racionalidade calculadora de maximização de prazer e minimização de dor que revisa as regras morais estabelecidas baseadas no princípio da utilidade, conforme o indivíduo realiza a ação, ao passo que o indivíduo teórico de Mill é um indivíduo mais complexo, ele não efetua apenas um balanço entre prazer e dor no momento de sua ação, porque ele possui novas características, quando comparado ao indivíduo de Jeremy Bentham. Isto faz com que no momento da ação ele não, necessariamente, revise as regras morais, não agindo a partir de um cálculo, mas sim, agindo de acordo com regras morais pertencentes a uma moralidade definida a partir deste novo indivíduo, com esta nova natureza, defendida por John Stuart Mill, e porque

\footnotetext{
${ }^{1}$ Note-se que Mill define os sentimentos como fruto de estados mentais, então torna-se difícil estabelecer esta linha divisória de onde finaliza a razão e começa os sentimentos, tudo que se sabe é que ambos são provocados por estados da mente, pois os estados da mente consistem em pensamentos, emoções, volições e sensações [Mill, 1843, Sistema de Lógica, Livro VI, Cap IV. P. 53].
} 
não dizer um novo indivíduo que age de acordo com um novo princípio de utilidade ${ }^{2}$, uma vez que o princípio de utilidade nada mais é do que a decorrência da natureza humana assim definida pelo autor.

\footnotetext{
${ }^{2}$ Será mostrado nesta tese que o princípio de utilidade elaborado por Mill preservará a tese hedonista formulada por Bentham a qual ressalta que as ações são corretas na medida em que tendem a promover a felicidade e erradas conforme tendam a produzir o contrário da felicidade e que todos os outros elementos buscados derivam seu valor do prazer ou felicidade causada, mas que muito é preciso ser dito para que se saiba o que está incluído nas idéias de dor e prazer (a subtese deste trabalho que afirma que Mill também segue a teoria hedonista, apesar de ser partidário de uma teoria hedonista mais complexa, pois o ser humano descrito por ele possui uma natureza humana mais complexa é de certa forma afirmada no segundo parágrafo do segundo capítulo do Utilitarismo, mais conhecido por 2.2 [Mill, 1861, p. 187].
} 


\title{
Capítulo I- O Indivíduo teórico de Bentham e sua Ética
}

1. Uma visão geral do indivíduo e da ética de Bentham

De acordo com o que foi defendido em minha dissertação de mestrado ${ }^{3}$ Uma Reconstrução Racional da Concepção Utilitarista de Bentham: Os Limites entre a Ética e a Legislação considerou-se como tese epistemológica do autor a afirmação de que o conhecimento é possível a partir da experiência, sem o auxílio de princípios transcendentais a priori. Ou seja, Bentham utiliza a tese epistemológica, denominada tese empirista, de que todo conhecimento provém da experiência:

\begin{abstract}
"Não estamos aqui diante de uma teoria nova e pouco segura, ou inútil. Com efeito, tudo quanto acabamos de expor representa um dado com o qual concorda plena $e$ perfeitamente a experiência ${ }^{4}$ do gênero humano, onde quer que os homens possuam uma visão clara acerca dos seus próprios interesses [...]"..[Bentham, 1789 p. 24]
\end{abstract}

A partir desta tese epistemológica, pode-se afirmar que o autor elaborou um recurso metodológico capaz de tornar operacional sua epistemologia. De acordo com este recurso, foi mostrado em minha dissertação de mestrado, que os indivíduos conhecem a partir de duas classes de entidades: a) a perceptiva e b) a inferencial, a partir das quais ele se relaciona com ele mesmo, com os outros e com o mundo. Tais entidades podem ser tanto reais quanto fictícias ${ }^{5}$. Entidades reais são aquelas que possuem existência na realidade das coisas (incluem substâncias corpóreas, coisas materiais e impressões sensoriais como prazer e dor).

As entidades fictícias são nomes cuja existência não lhes pode ser atribuída na realidade. Elas são expressões da linguagem que não podem ser reduzidas gramaticalmente a nomes reais, tais como os substantivos direito, dever, obrigação, lei e

\footnotetext{
${ }^{3}$ Ver Dias, 2007, p. 29

${ }^{4}$ Grifo nosso.

${ }^{5}$ Bentham, 1814, em The Theory of Fictions p. 7: “[...] Entities may be distinguished into perceptible and inferential. An entity, whether perceptible or inferential, is either real or fictitious [...]”.
} 
ética. Direitos e obrigações são ditos existir, mas não se descreve sua existência na realidade das coisas, como se faz com entidades reais.

Apesar desta separação entre nomes reais e ficcionais, pode-se dizer que há uma conexão entre ambos os tipos de nomes, pois quando diz-se que há uma obrigação a ser cumprida ela é verdadeira e real de certa forma. Além disso, todo termo ficcional possui uma relação com um termo real, uma vez que pode gerar conseqüências que se explicam em termos de nomes reais, como a geração de prazer ou dor. Assim, uma concepção surge a partir desta relação que passa a exprimir o termo ficcional.

Desta forma, Bentham organizou um novo método de exposição ou análise de termos ficcionais denominado paráfrase. Este método consiste em um tipo de exposição de termos cuja unidade do significado está em frases ou proposições. Neste método uma frase é empregada para expor uma outra frase inteira que contenha a palavra que se quer explicar. Nisto consiste a diferença para o método de exposição de termos a partir da definição, pois nesta apenas uma frase é empregada para explanar uma palavra ${ }^{6}$.

Tal método, denominado paráfrase, consiste, resumidamente, em: encontrar uma sentença que contenha o termo ficcional como sujeito, um predicado que designe uma propriedade do sujeito e um termo de ligação entre eles, denominado copula ${ }^{7}$, achar uma tradução para tal sentença em uma ou mais sentenças em que o termo ficcional que se deseja explicar não apareça e que contenha uma concepção de relação com um termo real e construir uma imagem a partir de um arquétipo que exprima o termo ficcional, em termos de sensações que se traduzam, especialmente, em prazer e dor ${ }^{8}$.

Ou seja, o objetivo desta forma de explicar termos ficcionais é sempre ter em vista sua relação com termos reais como prazer e dor, pois sem esta relação torna-se impossível estabelecer uma real compreensão destes termos. Em outras palavras, só faz

\footnotetext{
${ }^{6}$ Bentham, 1814, Bentham's Theory of Fictions p. 139: “[... In a definition, a phrase is employed for the exposition of a single word: in a paraphrases, a phrase is employed for the exposition of an entire phrase, of which the word, proposed to be expounded, is made to constitute the principal or characteristic word (...)”.

${ }^{7}$ Bentham, 1814, Bentham's Theory of Fictions p. 86-87: “[...] In every proposition by which a property or affection of any kind, real or fictitious, three parts or members are necessarily either expressly or virtually included, viz. (I) A subject, being the name of the real or fictitious entity in question: (2) A predicate by which is designated the property or affection attributed or ascribed to that subject: and (3) The copula, or sign of the act of the mind by which the attribution or ascription is performed [...]".

${ }^{8}$ Bentham, 1814, Bentham's Theory of Fictions p. 87: “[...] This image may be termed the archetype, emblem, or archetypal image appertaining to the fictitious proposition of which the name of the characteristic fictitious entity constitutes a part [...]".
} 
sentido falar de entidades fictícias quando associadas às entidades reais como prazer e dor:

"[...] Of any such fictitious entity, or fictitious entities, the real entity with which the import of their respective appellatives is connected, and on the import of which their import depends, may be termed the real source, efficient cause, or connecting principle [...]". [Bentham, 1814 p.86]

Um exemplo pode ser mostrado através da explicação do termo ficcional obrigação ${ }^{9}$. Tal exemplo serviu de ilustração para mostrar como ocorre a tradução de termos ficcionais para reais em minha Dissertação de Mestrado defendida em 2007. Inicialmente constrói-se uma proposição com a palavra obrigação como sujeito: "A obrigação é incumbente em um homem". Após a construção desta frase, elabora-se outra em que o termo obrigação não apareça, relacionando-o com um termo real, como no exemplo: a incumbência traz consequiências dolorosas a um homem. Por fím constrói-se uma imagem, por meio de um arquétipo que poderia ser a figura de um homem deitado com um peso sobre ele ${ }^{10}$.

A partir desta forma de explicação (paráfrase), que torna possível manter uma relação de termos ficcionais com termos reais (no caso dor), é possível entender o significado de obrigação. Ou seja, a explicação dos termos ficcionais deve, em todos os casos, manter uma relação com os termos reais, para que as consequiências dos primeiros termos possam ser traduzidas pelas conseqüências dos segundos.

Assim, tendo em vista a tese epistemológica de Bentham, a partir da qual o conhecimento provém da experiência e seu recurso metodológico para operacionalizá-la (que divide as entidades entre reais e ficcionais), conclui-se que termos como legislação, ética, obrigação, dever, direito e outros não são entes misteriosos ou naturais, mas sim construções humanas que podem e devem ser alteradas sempre com vistas a suscitar mais prazer do que dor para indivíduos.

\footnotetext{
${ }^{9}$ Bentham, 1814, Bentham's Theory of Fictions p. 89: “[...] The fictitious entities which compose this group have all of them, for their real source, one and the same sort of real entity, viz sensation: the word being taken in that sense in which it is significative not merely of perception but of perception considered as productive of pain alone of pleasure alone, or of both [...]".

${ }^{10}$ Bentham, 1814, Bentham's Theory of Fictions p. 90: "[...] the emblematical, or archetypal image, is that of a man lying down, with a heavy body pressing upon him [...]".
} 
Da epistemologia do autor depreende-se ${ }^{11}$ a tese ontológica que identifica prazer, dor e o indivíduo com entidades reais, ou seja, para análise política o que existe é o indivíduo capaz de experimentar duas sensações também reais, a saber: prazer e dor. Assim, os princípios da moral e da legislação de Bentham são construídos a partir de considerações a respeito do indivíduo ${ }^{12}$. Segue-se desta proposição ontológica uma série de consequiências metodológicas, entre elas, a de que a sociedade ou comunidade, para Bentham, nada mais é do que a soma dos indivíduos que a integram, ou em suas palavras, um corpo fictício ${ }^{13}$.

De acordo com o que defendi em minha dissertação de mestrado ${ }^{14}$ Uma Reconstrução Racional da Concepção Utilitarista de Bentham: Os Limites entre a Ética e a Legislação, o modelo de indivíduo que se pode deduzir a partir do sistema teórico de Bentham é algo que se aproxima do seguinte: a) o indivíduo dotado da capacidade de experimentar duas sensações reais (prazer e dor) é a entidade ontológica fundamental, para análise política, pois é o único que possui existência na realidade, b) este indivíduo busca o prazer e foge da dor, ou seja, é auto-interessado ${ }^{15} \mathrm{e}$ c) o indivíduo possui a faculdade intelectual de uma razão que calcula, ele é capaz de fazer cálculos intertemporais, inclusive no que diz respeito às conseqüências das ações.

Na Dissertação de Mestrado defendida em 2007 justificou-se essas três afirmações sobre o modelo de indivíduo teórico de Bentham da seguinte forma:

A primeira afirmação, daquele trabalho, sobre o modelo de indivíduo, referente à tese de que ele é a entidade ontológica fundamental para análise política, remete ao recurso epistemológico criado pelo autor, acima descrito. Ou seja, a divisão

\footnotetext{
${ }^{11}$ Faz-se, aqui, a pressuposição de que a epistemologia determina ou implica elementos ontológicos.

${ }^{12}$ Bentham, 1789, em Uma Introdução aos Princípios da Moral e da Legislação p. 10: "[...] É inútil falar do interesse da comunidade, se não se compreender qual é o interesse do indivíduo. Diz-se que uma coisa promove o interesse de um indivíduo, quando tende a aumentar a soma total de seus prazeres, ou então, o que vale afirmar o mesmo, quando tende a diminuir a soma total das suas dores [...]".

${ }^{13}$ Bentham, 1789, em An Introduction to the Principles of Morals and Legislation p. 10: “[...] The community is a fictitious body, composed of the individual persons who are considered as constituting as it were its members. The interest of the community then is, what? - the sum of the interests of the several members who compose it [...]".

${ }^{14}$ Ver DIAS 2007, p. 33.

${ }^{15}$ Bentham, 1817, em A Table of Springs of Actions p. 211-212: “[...] In regard to interest, in the most extended, - which is the original and only strictly proper sense, -of the word disinterested, no human act ever has been, or ever can be, disinterested. For there exists not ever any voluntary action which is not the result of the operation of some motive, which has not for its accompaniment a corresponding interest, real or imagined [...]".
} 
dos termos entre reais e ficcionais, resultantes deste recurso metodológico de sua epistemologia, induz à conclusão de que para fins de análise política, o único elemento que possui existência ontológica é o indivíduo ${ }^{16}$ dotado de duas entidades, também reais, prazer e dor. Os outros termos políticos como comunidade, sociedade, direito, dever, obrigação, lei, constituem termos ficcionais, sem existência na realidade das coisas. Alguma existência lhes pode ser atribuída, apenas quando relacionados a termos reais, conforme descrito acima.

A segunda afirmação daquele trabalho referente ao fato do indivíduo ser auto-interessado, é efetuada, pois é possível verificar um maior número de passagens que sugerem que o indivíduo realiza todos seus esforços, sempre, no sentido de maximizar seu prazer e fugir da dor. Em outras palavras este indivíduo age, em todos os casos, com o intuito de realizar seus próprios interesses. A terceira afirmação sobre o modelo de indivíduo que diz respeito à sua racionalidade é chamada, por Bentham, de faculdade intelectual. A principal característica desta faculdade intelectual refere-se à capacidade que ela possui de efetuar cálculos, previsões e antecipações das consequiências das ações, com base em experiências passadas e levando em conta a imaginação. Esta razão calcula, prevê, compara e estima os valores de prazeres e dores que acompanham as ações ${ }^{17}$. Os homens são, assim, diferenciados dos animais, especialmente, por possuírem uma razão capaz de efetuar cálculos intertemporais que antecipa e faz previsões sobre as consequiências de ações ${ }^{18}$. O exercício da razão humana constitui o principal instrumento de condução dos homens à felicidade.

\footnotetext{
${ }^{16}$ Bentham 1789, em An Introduction to the Principles of Morals and Legislation p. 2: "[...] It is in vain to talk of the interest of the interest of the community, without understanding what is the interest of the individual [...]".

${ }^{17}$ Bentham, 1834, em Déontologie ou Science de la Morale p.144: “[...] La raison fait servir les événements de l'un à l'instruction de l'autre: elle appelle à son aide non seulement l'expérience, mais encore l'imagination. Le domaine de son influence est sans limite comme la pensée : elle recherche les conséquences, et les présente aux regards de l'investigateur: elle dégage les peines et les plaisirs de l'alliage qui les accompagne : elle analyse leur valeur en les divisant dans leurs parties constitutives, ou les réunit en un tout afin de s'assurer de leur somme totale: elle les compare l'un avec l'autre quand ils sont classés chacun dans sa division respective, et de ces éléments réunis elle généralise et déduit le résultat définitif [...]”.

${ }^{18}$ Bentham, 1834, em Déontologie ou Science de la Morale p.144: “[...] La plupart des animaux inférieurs ne sont arrêtés dans leur recherche du plaisir par aucune anticipation de peine à venir. Nulle appréhension des conséquences ne peut les engager à s'abstenir d'une jouissance actuelle. Si l'on en excepte quelques uns des plus intelligents, toutes les leçons sont perdues pour eux, même celles de l'expérience : peut-être aussi cette perte de l'expérience est-elle attribuable à l'imperfection de leur mémoire [...]".
} 
Por meio destas considerações sobre o modelo de indivíduo teórico de Bentham, é possível depreender que as ações humanas são guiadas pelos sentimentos de prazer e dor. São eles que apontam o que se deve fazer, bem como o que de fato os indivíduos fazem. Bentham ressalta que estes são os dois senhores soberanos das ações e pensamentos dos agentes. Aos prazeres e dores estão vinculadas: a) a norma que distingue o que é certo do que é errado e b) a cadeia de causas e efeitos de uma ação ${ }^{19}$.

Tendo em vista os sentimentos de prazer e dor como aquilo que governa ${ }^{20}$ as ações humanas, o autor descreve o princípio da utilidade como aquele que reconhece a sujeição do indivíduo a estes sentimentos e tem o objetivo de colocá-los como fundamento para a construção de um corpo teórico que vise a melhor sociedade possível $^{21}$.

Dentro deste contexto a explicação do princípio é formulada, por Bentham, da seguinte maneira:

"[...] Por princípio da utilidade entende-se aquele princípio que aprova ou desaprova qualquer ação, segundo a tendência que tem a aumentar ou a diminuir a felicidade da pessoa ${ }^{22}$ cujo interesse está em jogo, ou, o que é a mesma coisa em outros termos, segundo a tendência a promover ou a comprometer a referida felicidade. Digo qualquer ação, com o que tenciono dizer que isto vale não somente para qualquer ação de um indivíduo particular, mas também de qualquer ato ou medida de governo [...]”. Ou, em outros termos, o princípio da utilidade é explicado da seguinte forma: "[...] O princípio que estabelece a maior felicidade de todos aqueles cujo interesse está em jogo, como sendo a justa e adequada finalidade da ação humana, e até a única finalidade justa, adequada e universalmente desejável: da

\footnotetext{
${ }^{19}$ Bentham, 1789 em Uma Introdução aos Princípios da Moral e da Legislação p. 10: “[...] A natureza colocou o gênero humano sob o domínio de dois senhores soberanos: a dor e o prazer. Somente a eles compete apontar o que na realidade faremos. Ao trono desses dois senhores está vinculada a norma que distingue o que é reto do que é errado, e por outra, a cadeia das causas e dos efeitos [...]".

${ }^{20}$ Bentham, 1789, em Uma Introdução aos Princípios da Moral e da Legislação p. 9: “[...] Os dois senhores de que falamos nos governam em tudo o que fazemos, em tudo o que dizemos, em tudo o que pensamos, sendo que qualquer tentativa que façamos para sacudir este senhorio outra coisa não faz senão demonstra-lo e confirmá-lo [...]".

${ }^{21}$ Bentham, 1789, em Uma Introdução aos Princípios da Moral e da Legislação p. 9: “[...] O princípio da utilidade reconhece esta sujeição e a coloca como fundamento desse sistema, cujo objetivo consiste em construir o edifício da felicidade através da razão e da lei [...]".

${ }^{22}$ Nesta passagem, a tradução da palavra party por pessoa é equivocada, pois em inglês este termo possui um significado coletivo.
} 
ação humana, digo, em qualquer situação ou estado de vida, sobretudo na condição de um funcionário ou grupo de funcionários que exercem os poderes do governo [...]".(BENTHAM, 1789, p.10).

Reconhecida, pelo princípio da utilidade, a sujeição do gênero humano aos sentimentos de prazer (felicidade) e dor (infelicidade), este passa a ser a norma para julgamento do que é certo e errado. Ou seja, o princípio de utilidade é aquele que reconhece a justeza de uma ação de acordo com suas conseqüências. Ele representa uma regra metodológica que aponta que aquilo que deve ser levado em conta (avaliado), em todas as circunstâncias, são as consequiências das ações. Em outras palavras, este princípio considera uma ação justa pela capacidade que tem de gerar mais prazer do que dor e injusta por ocasionar mais dor do que prazer.

O princípio de utilidade é ele mesmo uma regra que enuncia que aquilo que importa são as conseqüências das ações. Em outras palavras, exatamente porque o princípio de utilidade reconhece que o gênero humano está sob a sujeição dos sentimentos de prazer e dor é que ele prescreve que a forma justa de avaliar ações dá-se pela pelo exame da produção destes sentimentos, através das conseqüências das ações.

Segundo foi afirmado em minha Dissertação em 2007, existem quatro fontes distintas que ocasionam prazer e dor: a) física, b) política, c) moral e d) religiosa ${ }^{23}$. Se o prazer ou a dor se espera na vida presente e no curso ordinário da natureza, então, o prazer é denominado sanção física. Se for esperado de uma pessoa ou de um grupo da comunidade, sob nome de juiz, pode-se dizer que é derivado da sanção política. Caso o poder de gerar prazer ou dor estiver nas mãos de pessoas que por acaso ocupam um lugar de destaque na comunidade, segundo disposição espontânea, pode-se dizer que o prazer e a dor derivam da sanção moral. Se dependerem de ser superior invisível, quer na vida presente, ou na vida futura, então é derivado de sanção religiosa ${ }^{24}$.

\footnotetext{
${ }^{23}$ Bentham, 1789, Uma Introdução aos Princípios da Moral e da Legislação p. 19: “[...] Existem quatro fontes distintas, das quais costumam derivar o prazer e a dor: consideradas em separado, podemos designa-las como fontes física, fonte política, fonte moral e fonte religiosa. Na medida em que os prazeres $e$ as dores pertencentes a cada uma delas são capazes de emprestar a qualquer lei ou regra de conduta uma força obrigatória, todas elas podem ser denominadas sanções [...]”.

${ }^{24}$ Bentham acrescenta a sanção religiosa como forma de dialogar com o público de sua época.
} 
$\mathrm{O}$ autor ressalta que os indivíduos apenas ocupam-se dos prazeres da vida presente, além disso, acrescenta que os prazeres pertencentes a cada sanção são iguais, uma vez que são sentidos fisicamente ${ }^{25}$. A única diferença encontra-se nas circunstâncias que acompanham a sua produção (por exemplo: a circunstância ou fonte política é diferente da circunstância ou fonte moral $)^{26}$.

Disto, é possível depreender que a sanção física é o fundamento da sanção política, moral e religiosa. Nenhuma destas fontes pode operar senão por meio das forças da natureza, por meio do prazer ou dor física ${ }^{27}$. Por este motivo, torna-se possível comparar, metodologicamente, os prazeres e dores de cada pessoa, diferenciado-os por sua quantidade (mais prazer, mais dor, menos prazer, menos dor).

O autor, inclusive, desenvolve um método para mensurar a tendência de uma ação a produzir o bem (prazer) ou o mal (dor).

A mensuração do prazer e da dor inicia-se com considerações sobre os indivíduos afetados pela ação em questão. Não poderia ocorrer de outra maneira, dado que é sustentada, neste trabalho, a tese ontológica que identifica o indivíduo como aquele que possui existência para análise política.

Assim, para um indivíduo considerado em si mesmo, o valor de um prazer ou de uma dor será maior ou menor segundo as quatro circunstâncias ou propriedades: 1) intensidade, 2) duração, 3) certeza ou incerteza, 4) proximidade ou longinquidade ${ }^{28}$. Com relação à tendência geral do ato (consequiências das ações), leva-se em conta duas outras circunstâncias ou propriedades, quais sejam: 5) fecundidade (probabilidade que o prazer ou a dor tem de serem seguidos por sensações de mesma espécie) e 6) pureza

\footnotetext{
${ }^{25}$ Bentham chama os prazeres de "pathological". Aqueles que não são desta espécie, como os prazeres da mente, são denominados inertes. Sobre isto cito BENTHAM, 1817, em a Table of Springs of Actions p. 206:" [...] For pathological might here have been put the more ordinary adjunct physical, were it not that, in the case, those pleasures and pains, the seat of which is not in the body but only in the mind, might be regarded as excluded [...]".

${ }^{26}$ Bentham, 1789, em Uma Introdução aos Princípios da Moral e da Legislação p. 20: “[...] No que respeita, portanto, aos prazeres e às dores da vida presente [...] podemos afirmar o seguinte: aqueles que pertencem a qualquer uma dessas sanções, em última análise, não diferem especificamente daqueles que pertencem a qualquer uma das outras três: a única diferença existente entre eles reside nas circunstâncias que acompanham a sua produção [...]".

${ }^{27}$ Bentham, 1789, em Uma Introdução aos Princípios da Moral e da Legislação p. 21: “[...] das quatro sanções de que tratamos até aqui, podemos observar que a física é o fundamento da política e da moral, o mesmo acontecendo em relação a religiosa, na medida em que se relaciona com a vida presente [...]”.

${ }^{28}$ Estes recursos utilizados para avaliar as propriedades do prazer ou dor, descritos pelo autor, reforçam o modelo de indivíduo que diz que o agente é capaz de efetuar cálculos intertemporais sobre prazeres e dores.
} 
(probabilidade que o prazer e a dor possuem de não serem seguidos por sensações

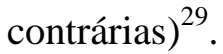

Em seguida verifica-se a extensão ou o número de indivíduos afetados pela ação avaliada. Considerando estes elementos, o valor do prazer e da dor será maior ou menor conforme as sete circunstâncias: 1) intensidade, 2) duração, 3) certeza ou incerteza, 4) proximidade ou longinquidade, 5) fecundidade, 6) pureza, e 7) extensão (número de pessoas as quais se estende o respectivo prazer ou dor ${ }^{30}$ ).

Assim, para realizar-se a avaliação exata da tendência geral de qualquer ato que afeta os interesses de uma coletividade, procede-se começando por qualquer pessoa cujos interesses pareçam ser mais imediatamente afetados pelo ato e apreciam-se os seguintes elementos: 1) o valor de cada prazer distinto que se manifesta como produzido pelo ato em primeira instância (variará segundo a intensidade, duração, proximidade ou longinquidade, certeza ou incerteza), 2) faz-se o mesmo para a dor, 3) o valor de cada prazer produzido pelo ato após o primeiro prazer, que é a fecundidade do primeiro prazer (e a impureza da primeira dor), 4) procede-se o mesmo para a dor, 5) somam-se todos os valores dos prazeres de um lado e os valores de todas as dores do outro. $\mathrm{O}$ balanço, se for favorável ao prazer, indicará a tendência boa do ato para o primeiro indivíduo. Se for favorável à dor, indicará a tendência má do ato para este mesmo agente, 6) faz-se uma avaliação do número de pessoas cujos interesses aparecem em jogo e repete-se o procedimento acima em relação a cada um dos indivíduos, 7) a seguir, aplica-se, então, o princípio de agregação das consequiências da ação: soma-se ${ }^{31}$ o número de graus de tendência boa com relação a cada um dos indivíduos, 8) faz-se o mesmo com respeito a cada indivíduo cuja tendência do ato é má, em seu conjunto e 9) feito isto, procede-se ao balanço. Este se for favorável ao prazer assinalará a tendência boa geral do ato. Se o balanço pesar para a dor, ter-se-á a tendência má geral do ato ${ }^{32}$.

\footnotetext{
${ }^{29}$ Ambas as circunstâncias não são propriedades do prazer ou da dor. Portanto, só devem ser consideradas na avaliação da tendência do ato.

${ }^{30}$ Note-se que a soma dos prazeres e dores de indivíduos só é possível porque os prazeres sentidos por cada um são iguais, diferindo apenas com relação às sete circunstâncias mencionadas .

${ }^{31}$ Note que é possível somar as tendências boas e más dos atos, porque qualitativamente e quantitativamente os prazeres, sentidos por cada indivíduo, são ditos [tirei: "são comparáveis"] "pathological” ou denominados com outros termos físicos.

${ }^{32}$ Apesar de insistir na adoção deste método, o autor diz que "[...] Não se pode esperar que o referido método possa ser seguido a rigor antes de qualquer julgamento moral, ou antes de qualquer ação legislativa ou judicial. Todavia o método como tal pode ser sempre mantido diante dos olhos: e, na medida
} 
Apesar de Bentham ressaltar que o legislador ou quem estiver considerando o balanço entre prazeres e dores deve mantê-lo sempre em vista, com a finalidade de evitar injustiças no julgamento das ações, não é possível exigir que este balanço seja observado com uma exatidão total.

Entretanto, esta breve descrição do modelo de indivíduo teórico de Bentham e deste método de mensuração da tendência geral de um ato são boas amostras das considerações acerca da natureza do indivíduo que o autor realiza. $O$ indivíduo governado pela capacidade de experimentar prazer e dor, ou seja, governando por seu auto-interesse, realiza cálculos em todas as ações para maximizar seu prazer e minimizar suas dores. Esta é a natureza do indivíduo teórico de Bentham, este é seu indivíduo racional, e todas as considerações políticas e morais do autor levarão em conta este modelo de indivíduo. A democracia, por exemplo, será o regime político escolhido para que os agentes possam expressar de forma mais clara seus interesses individuais e para que melhor possam vigiar e punir os homens de poder político que tentarem se apropriar privadamente de um aparato que é público. As formulações morais e éticas de Bentham também levarão em conta esta concepção de indivíduo.

Considerando estas breves explicações acerca da natureza do indivíduo teórico de Bentham, prossegue-se para verificar quais as implicações no que concerne à concepção ética do sistema do autor.

O significado de ética, em sentido amplo, para Bentham, é um princípio norteador das regras de conduta do agir moral para a produção de mais prazer do que dor, ou seja, é um princípio construído pelos homens visando o maior benefício de todos: ”(...) Ética em geral pode ser definida como a arte de dirigir as ações humanas na produção da maior quantidade possível de felicidade da parte cujo interesse está em jogo (...)”[Bentham, 1789, p. 69]. É possível depreender desta compreensão de ética que seu sentido coincide com o próprio significado do princípio de utilidade

Assim, tendo em vista que o princípio ético de ação coincide com o princípio da utilidade, questiona-se qual o conteúdo que deve constar nas normas do agir moral. Segundo Bentham estas regras não são nem mais nem menos do que as regras

em que o processo atualmente seguido nessas ocasiões se aproximar dele, na mesma medida tal processo se aproximará da exatidão [...]". Citação de uma Introdução aos Princípios da Moral e da Legislação, 1789, p. 24. 
condizentes com o princípio de utilidade, pois uma ação só pode ser dita correta caso gere mais prazer do que dor e só pode ser condenada caso gere mais dor do que prazer, no cômputo geral do balanço das conseqüências das ações.

Desta forma, os costumes que fazem parte das regras morais devem, também, passar pelo crivo do princípio de utilidade, pois, ressalta o autor, existem milhares de sentimentos que levam os indivíduos a crer que algo é certo ou errado, contudo, estes sentimentos só podem ser instrumentos válidos para condenar a ação de alguém caso este alguém aja no sentido de gerar dor.

Destas afirmações sobre a ética, depreende-se que não há ações boas ou más em si mesmas, motivos de ações bons ou maus em si mesmos, ou costumes bons ou maus em si. O que existe e deve ser levado em conta são as consequiências das ações. Só estas podem ser julgadas, pois só elas possuem a capacidade de gerar prazer ou dor em um indivíduo ${ }^{33}$. Inclusive, os vícios e virtudes só podem ser assim nomeados de acordo com as consequiências produzidas por determinada ação, ou conforme a potencialidade que tenham de ocasionar prazer ou dor.

Portanto, o bem moral, para Bentham, é dito existir quando a vontade humana é considerada como um instrumento na produção de um bem físico (prazer) ou na abstenção de uma dor ${ }^{34}$.

Baseando-se no que foi explicitado a respeito das ações concernentes às interações entre agentes, é possível levantar as seguintes questões: Quais motivos independentes daqueles que possam oferecer a legislação e a religião, pode uma pessoa ter para salvaguardar (probidade) ou promover (beneficência) a felicidade de outra? Em virtude de que motivos, em virtude de que deveres pode uma pessoa ser obrigada a obedecer aos ditames da probidade ou benquerença?

A resposta dada pelo autor concorda com o modelo de indivíduo traçado na minha Dissertação em 2007, pois os únicos interesses para praticar a salvaguarda de outros que uma pessoa possa encontrar como motivos adequados são seus próprios

\footnotetext{
${ }^{33}$ A respeito disto cito Bentham em An Introduction to the Principles of Moral and Legislation p. 69: “(...) The tendency of an act is mischievous when the consequences of it are mischievous; that is to say, either the certain consequences or probable (...)".

${ }^{34} \mathrm{~A}$ respeito disto cito Bentham em A Table of Springs of Actions p. 206: “(...) Moral good, is as above, pathological good, in so far as human will is considered as instrumental in the production of it: in so far as any thing else is made of it, either the word is without meaning, or the thing without value. And so in regard to evil (...)".
} 
interesses $^{35}$. Não obstante, não existe nenhuma ocasião em que uma pessoa não tenha alguns motivos para promover a felicidade de uma outra. Seja por: a) motivos sociais (simpatia e benevolência, que dependem da sensibilidade do agente), b) motivos semisociais (amor à amizade ou à reputação, que depende da variedade de circunstâncias, sobretudo conforme a força das faculdades intelectuais do agente, seu quantum de sensibilidade moral e os tipos de pessoas com as quais tenha que tratar).

Disto depreende-se que não existem, para Bentham, obrigações morais com força coercitiva, tal como a força que impõe a legislação, contudo, age mais de acordo com o princípio da utilidade aquele que leva em conta, em seus próprios interesses, os interesses de outros. Isto porque gera mais prazer, no cômputo geral, aquele que pratica a probidade ou a beneficência para com os outros indivíduos.

Além deste motivo que os indivíduos têm para agir no sentido de não causar injúrias a outros, bem como tentar levar em conta o aumento do cômputo geral de prazer em suas ações, há a reprovação ou sanção moral que membros da comunidade podem efetuar às ações consideradas perniciosas à sociedade.

Em outros termos, é possível afirmar que apesar de não possuir força coercitiva como as leis, a ética, para Bentham, também possui um instrumento capaz de constranger as ações dos indivíduos, a partir da geração de dor e prazer. Este instrumento é a sanção moral que é entendida por Bentham como uma fonte de prazer ou dor, que se encontra nas mãos de pessoas que por acaso ocupam um lugar de destaque na comunidade. Portanto, há no agir moral, regras informais não legais, com algum poder de coação, capazes de produzir prazer ou dor em indivíduos, conforme suas ações estejam ou não de acordo com o princípio de utilidade.

No que diz respeito aos pontos de convergência entre a ética e a legislação é possível afirmar que a ética tem por objetivo a felicidade, sendo este também o da legislação, ou seja, ambas apresentam pontos em comum: a) dizem respeito à felicidade e ações de cada um e b) as pessoas cuja felicidade devem ter em vista, bem como os indivíduos cuja conduta devem ocupar-se, são os mesmos. Isto foi afirmado em minha Dissertação de Mestrado de 2007.

\footnotetext{
${ }^{35}$ Sobre isto cito Bentham em Uma Introdução aos Princípios da Moral e da Legislação p. 71: “(...) Em resposta a tal interrogativo, é imperioso admitir que os únicos interesses para cuja salvaguarda uma pessoa possa encontrar, com certeza e sempre, motivos adequados são os seus próprios interesses (...)”.
} 
Tendo em vista, as três formas possíveis de agir do ser humano: a) ação com ausência de interações (prudência quando maximiza prazer), b) interações positivas (beneficência quando maximiza prazer) e c) interações negativas (probidade quando não se gera dor), depreende-se que a legislação tem como objetivo assegurar a probidade, ou a ausência do cometimento de injúrias, enquanto o raio de ação da ética é garantir a prudência e a beneficência.

Considerando adiantadamente, de maneira sucinta, a solução que será delineada na parte final deste capítulo, tem-se que: a ética tangenciará o ramo em que os indivíduos podem ocasionar injúrias uns aos outros, somente nos casos em que não for benéfica a aplicação de leis, em outros termos, apenas quando mais dor do que prazer for ocasionado a partir da formulação de normas formais. É interessante notar que aquilo que separa as normas da ética das normas da legislação é sempre uma aplicação direta do primeiro princípio ou preceito moral, a saber; uma aplicação do princípio direta do princípio de utilidade.

A legislação, contudo, não deve interferir nos casos relativos à prudência (eventos em que não há interação entre indivíduos), por uma questão de eficiência, também por uma questão de aplicação do princípio de utilidade, porque o balanço entre prazer e dor aponta para a não interferência da legislação, nestes casos, pois: a) o legislador não pode criar leis sobre este tema, uma vez que não pode conhecer mais sobre o indivíduo do que ele próprio e b) a ação coercitiva do governo, neste caso, pode instaurar um sentimento de perseguição aos costumes sociais, reduzindo os motivos sociais (por exemplo, diminuição da benevolência e amor à amizade) nos indivíduos. No que concerne à maneira de poder gerar o bem, recomenda-se que a área legal intervenha, somente, em casos específicos, como o salvamento de alguém, sem prejuízo do próprio indivíduo que salva ${ }^{36}$. Em outros eventos em que os indivíduos agem para gerar o bem a aplicação da legislação é desnecessária, pois descaracteriza a natureza do ato beneficente que concerne a uma disposição livre do agir de forma a ocasionar $\operatorname{prazer}^{37}$ :

Ao final deste cpítulo será concluída de forma detalhada a separação entre o raio de ação da ética e da legislação, no que diz respeito aos três tipos de ações acima

\footnotetext{
${ }^{36}$ Ver Dias, 2007.

${ }^{37}$ Bentham, 1789, em An Introduction to the Principles of Moral and Legislation p.148: "[...] In many cases the beneficial quality of the act depends essentially upon the disposition of the agent [...]”.
} 
descritas (sem interação, com interação que ocasiona o bem e com interação que pode gerar o mal). O que se deve ter claro é que, em todos os casos, quando se faz a análise dos três tipos de ações, o guia desta separação da atuação de ambos os temas (ética e legislação) é o princípio de utilidade através de um balanço entre prazer e dor das conseqüências das ações, não havendo diferença de natureza entre o conteúdo da regras que constam na moral e na legislação, ou seja, a diferença está em um cálculo de custo benefício. Deve-se ter claro que o agente de Bentham nunca age por meio de princípios secundários, mas sempre por meio de um apelo ao princípio de utilidade.

Da sucinta explicação dada acima sobre as distinções entre a ética e a legislação, para que se delimite o espaço ou raio de atuação da ética, depreende-se que ambas apresentam as seguintes diferenças: a) não existe diferença de natureza entre as ações da ética e da legislação, contudo os atos com que ambas se ocuparão serão diferentes, pois é o balanço entre prazer e dor que determinará onde cada regra permanecerá (se no raio de atuação da ética ou da legislação) b) quanto à legislação há casos em que o legislador não deve intervir na conduta dos membros da comunidade, também por uma questão de eficiência (eventos relativos à prudência, beneficência e parte dos casos de probidade). Conforme mencionado, as diferenças entre a ética e a legislação ocorrem, pois o princípio de utilidade prescreve, a partir de um cálculo de custo benefício para a sociedade, o raio de atuação de ambas.

Segundo tem-se mostrado a prudência e beneficência ficam sob o escopo da ética, por ser mais benéfico à sociedade, enquanto que a probidade permanece sob o raio de ação da legislação, pela mesma razão, embora não completamente. Também tem-se insistido no fato de que isto é o mesmo que dizer que o princípio da utilidade estabelece, por meio de um cálculo de custo benefício, o raio de atuação de ambos os temas ${ }^{38}$.

No que diz respeito ao agir negativo (abster-se ou não de gerar dor) argumentou-se que o legislador não pode evitar todos os atos prejudiciais (ofensas) praticados por uma pessoa contra a comunidade, pois o mal em tentar evitar tais atos pode ser maior do que os benefícios auferidos.

Desta forma, além das áreas que são próprias da ética, como prudência e beneficência, cabe analisar quais são os eventos de interferência da ética que seriam

${ }^{38}$ Ver Dias, 2007. 
próprios do setor legal. Em outros termos, cabe verificar quais casos não se deve punir, quando um mal é gerado, mas apenas e tão somente deixar o mal sob intervenção das regras da ética.

Contudo, antes de analisar estes casos, uma indagação torna-se pertinente: qual o princípio ou qual pressuposto que estará por traz do argumento de que um caso próprio da legislação não deve estar sob sua área de atuação, mas sob a intervenção da ética ${ }^{39}$ ?

Do mesmo modo que o princípio da utilidade, através de uma prescrição embasada em cálculo de custo benefício, determina que a prudência e beneficência devem ser matéria da ética e que a probidade deve ser assunto da legislação, é possível sustentar a afirmação de que será o princípio da utilidade (balanço entre prazer e dor ou custos e benefícios da punição, aplicada à sociedade) que delimitará os limites dentro dos quais o setor penal, legislativo pode atuar. Portanto, os tipos de atos prejudiciais que não podem ser abrangidos pela lei, por aplicação do próprio princípio de utilidade, constituem a resposta que faltava para a delimitação do campo da ética para com a legislação.

Considerando estes elementos, segue-se a resposta sobre a delimitação das normas que ficam restritas entre a ética e a legislação, no que concerne aos casos em que não cabe punir.

${ }^{39}$ Ibid. 
2 Casos em que não cabe punir

Segundo tem-se reiterado a legislação tem por objetivo excluir o mal da sociedade, tem o objetivo de salvaguardar a felicidade da comunidade. Contudo, ao mesmo tempo em que a legislação tem por objetivo impedir um mal, ela produz outro mal através da punição. De acordo com o princípio da utilidade, um mal é admitido somente para impedir ou excluir um mal ainda maior. Uma vez mais, resta claro que o agente de Bentham faz um apelo direto ao primeiro princípio, para decidir se a punição deve ou não ser aplicada.

Tendo em vista que a punição é um mal, torna-se necessário verificar quais casos (em que um mal é gerado) não são passíveis de punição, para que estejam de acordo com o princípio da utilidade (balanço favorável ao prazer).

Todo esforço da legislação penal deve ser feito para impedir ou minimizar os crimes, tendo, sempre, em vista que a própria punição causa dor. Desta forma, o critério de punição, de Bentham, afasta-se, totalmente, da noção de vingança, aproximando-se da idéia de proporcionalidade entre crime e punição. Em outras palavras, a dor gerada pela punição deve ser, em todos os casos, a menor possível, suficiente apenas para desestimular crimes, quando houver vantagem para a sociedade (quando valer a pena formular normas legais). Quando não for benéfico, quando o balanço entre prazer e dor apontar para a não formulação de regras da legislação, estas não devem ser formuladas e as normas permanecerão no escopo da ética.

Depreende-se, portanto, que alguns casos não devem ser tocados pela lei ou pela punição e é precisamente nestes casos que reside a resposta para o campo de atuação da ética de Bentham, além dos campos de atuação que são próprios dela, como a área da prudência e beneficência. Em outros termos, indaga-se: quais casos não devem ser abrangidos pela lei? Dentre os casos que não devem ser tocados pela lei, quais são matéria da ética?

Levando em conta estas questões, apresenta-se, abaixo, a análise dos casos que supostamente deveriam ficar sob a área da legislação, pois supostamente ocasionariam um mal, mas entende-se que a punição legal não deve ser aplicada, por uma 
decisão de aplicação do princípio da utilidade (balanço favorável ao prazer ou à minimização de dor $)^{40}$ :

a) Quando a aplicação da pena é infundada: não há mal a ser evitado

b) Quando a punição é ineficaz, em outros termos, quando nenhuma punição pode evitar o mal a ser causado.

c) Quando a aplicação da pena não é proveitosa (unprofitable), ou muito custosa, ou seja, quando o mal causado pela punição seria maior do que o mal causado pelo crime, em termos financeiros.

d) Quando a punição é desnecessária: nos casos em que o mal pode ser impedido ou cessar por si só, sem a punição. Isto consiste em dizer que o mal pode cessar a uma taxa mais barata.

a) Casos nos quais a aplicação da pena é infundada ${ }^{41}$

São eventos em que nunca houve um mal, quando nenhum mal foi produzido a algum indivíduo pelo ato em questão. Em algumas ocasiões, tal ato foi considerado pernicioso, mas a pessoa afetada pelo ato deu seu consentimento para a ocorrência dele. De acordo com Bentham, ninguém pode ser melhor juiz do que é ou não prazeroso do que o próprio homem afetado por um ato. Em outras palavras, se existe consentimento o legislador não deve intervir, pois é o próprio indivíduo que deve decidir aquilo que lhe é mais prazeroso. ${ }^{42}$

A aplicação da pena também é considerada infundada quando o mal causado pela ação é superado por um prazer. Ou seja, embora um mal tenha sido produzido por um ato, este se fazia necessário para a geração de um benefício de maior valor. Este é o

\footnotetext{
${ }^{40}$ Bentham, 1789, em An Introduction to the Principles of Moral and Legislation p. 83: "[...] But all punishment is mischief: all punishment in itself is evil. Upon the principle of utility, if it ought at all to be admitted, it ought only to be admitted in as far as it promises to exclude some greater evil [...]".

${ }^{41}$ Bentham, 1789, em An Introduction to the Principles of Moral and Legislation p. 83: "[...] Where it is groundless: where there is no mischief for it to prevent: the act not being mischievous upon the whole $[\ldots] "$.

${ }^{42}$ Bentham, 1789 em An Introduction to the Principles of Moral and Legislation p. 84: “[...] This consent, provided it be free, and fairly obtained, is the best proof that can be produced, that, to the person who gives it, no mischief, upon the whole, is done. For no men can be so good a judge as the man himself, what it is gives him pleasure or displeasure [...]".
} 
caso do exercício de vários tipos de poderes necessários a serem estabelecidos em todas as comunidades, a saber: judicial, militar e supremo ${ }^{43}$. Eles são considerados males necessários, pois são extremamente onerosos à comunidade. Em outras palavras, para implementação destes poderes custos ou males são impostos, sendo, contudo, superados por prazeres ou benefícios gerados.

Ademais, as penas serão infundadas caso haja a certeza de uma compensação adequada. Esta compensação pressupõe dois aspectos: 1) a ofensa é tal que admite adequada compensação e 2) tal compensação certamente virá em um futuro próximo $^{44}$.

b) Casos em que a punição é ineficaz ${ }^{45}$

Os casos ineficazes referem-se às ofensas praticadas antes que constassem na legislação. De acordo com o autor, um juiz não pode, de acordo com a sua vontade, condenar um ato, antes que conste na legislação. Outro caso em que a punição é considerada ineficaz refere-se às situações em que a provisão penal, então estabelecida, não é conduzida ao conhecimento da pessoa à qual pretende-se aplicar a pena.

Outros casos em que a punição é considerada ineficaz referem-se a eventos em que a provisão penal foi conduzida ao conhecimento do indivíduo ao qual se pretende aplicar a pena, contudo, com certeza, não surtirá efeito algum sobre ele, no que diz respeito a demovê-lo de efetuar o ato que se quer impedir. Seguem alguns exemplos: 1) a infância constitui um caso em que a legislação não é capaz de influenciar a conduta dos agentes, 2) no caso de insanidade, 3) no caso em que o agente aja contrariamente à sua vontade como nos eventos relacionados à intoxicação, como uso de drogas ${ }^{46}$.

Adicionalmente às situações acima descritas, a punição é também considerada ineficaz quando o indivíduo não sabe que o ato que ele está prestes a praticar

\footnotetext{
${ }^{43}$ Bentham, 1789, em An Introduction to the Principles of Moral and Legislation p. 84: "[...] This may be the case with any thing that is done in the way of precaution against instant calamity, as also with any thing that is done in the exercise of the several sorts of powers necessary to be established in every community, to wit, domestic, judicial, military, and supreme [...]".

${ }^{44}$ Bentham admite que esta última suposição não pode ser verificada de fato, mas apenas vislumbrada.

${ }^{45}$ Bentham, 1789, em An Introduction to the Principles of Moral and Legislation p. 83: "[...] Where it must be inefficacious: where is cannot act so as to prevent the mischief [...]".

${ }^{46}$ Ver Dias, 2007.
} 
se relaciona às penas previstas. Exemplos: 1) no caso da não intencionalidade, em que o indivíduo não pretende realizar o ato pernicioso, mas o fará sem intenção, 2) no caso da inconsciência, quando o indivíduo sabe que cometerá o ato, porém não sabe que as circunstâncias materiais que envolvem o ato transformarão o ato em pernicioso, tornando a tendência de produzir mal oculta para ele e 3) no caso em que o indivíduo acredita que seu ato não produzirá mal ou gerará um bem maior do que o mal que possa ocasionar. Em outras palavras, o indivíduo faz suposições errôneas, a partir de certas circunstâncias levadas em conta.

Nos casos em que alguma outra causa determinante obrigue o agente a praticar tal ato, a punição também torna-se ineficaz, mesmo que haja uma influência da lei sobre o agente. Por exemplo, nos casos em que os males aos quais o indivíduo tenha que tentar resistir sejam extremamente grandes. Isto pode ocorrer: 1) nos eventos de danos causados por poderes da natureza e 2) no caso de um mal ameaçador causado por outro homem (como a partir da sanção moral e religiosa podendo ser maior do que qualquer pena que o legislador possa imprimir).

Finalmente, a pena é considerada ineficaz, quando por suas faculdades físicas o agente é impedido de agir de acordo com sua vontade, mesmo que a cláusula penal exerça uma influência completa sobre sua vontade. Em outras palavras, as condições de ação do agente são totalmente involuntárias.

c) Casos em que a punição é não proveitosa (ou não lucrativa) ${ }^{47}$

Quando o mal resultante da punição é maior do que o bem que se deseja auferir dela, a punição é dita ser não proveitosa ou excessivamente custosa. Por influência de algumas circunstâncias, o mal da punição, neste caso, é maior do que o mal da ofensa, somando-se a ela, sem que um benefício suficiente seja auferido. Por exemplo: a) nos casos em que os serviços penais se tornam extremamente onerosos, privando a comunidade de se beneficiar de outros serviços estatais, b) nos casos em que a

\footnotetext{
${ }^{47}$ Bentham, 1789, em An Introduction to the Principles of Moral and Legislation p. 83: "[...] Where it is unprofitable, or too expensive: where the mischief it would produce would be greater than what it would prevent $[\ldots] "$.
} 
comunidade não deseja punir determinada ofensa ou determinado ofensor, em uma dada circunstância, da maneira corrente ${ }^{48}$.

d) Casos em que a punição não se faz necessária ${ }^{49}$.

Esses são os eventos em que é possível colocar um fim a uma determinada ação a uma taxa mais barata, de alguma outra forma, do que utilizando a punição legal, como, por exemplo, através da instrução, informando o entendimento ou pela influência direta na vontade. Estes casos parecem ser aqueles em que alguns disseminam idéias perniciosas para a sociedade. Para estancar tais idéias o autor ressalta ser melhor agir com a caneta e não com punição ${ }^{50}$. A intervenção do governo através do uso de palavras não impedirá que muitos autores escrevam teorias com conseqüências maléficas à sociedade, mas evitará que tais teorias sejam tomadas como verdadeiras.

Indaga-se onde se encontra a linha divisória (entre a legislação e a ética), no que concerne aos casos de interação negativa entre indivíduos (abstenção ou não de gerar dor), considerando os casos em que não cabe aplicação da legislação. A resposta até este momento tem sido conduzida com base no critério do balanço entre prazer e dor, com base em um apelo direto ao primeiro princípio. Este mesmo critério apontará em quais destes casos a legislação não deve atuar, mas apenas as regras da ética ${ }^{51}$.

\footnotetext{
${ }^{48}$ Ver Dias, 2007.

${ }^{49}$ Bentham, 1789, em An Introduction to the Principles of Moral and Legislation p. 84: "[...] Where it is needless: where the mischief may be prevented, or cease of itself, without it, that is, at a cheaper rate (...)".

${ }^{50}$ Bentham, 1789, em An Introduction to the Principles of Moral and Legislation p. 83: "[...] But if the sovereign must needs take a part in the controversy, the pen is the proper weapon to combat error with, not the sword [...]".

${ }^{51}$ Bentham, 1789, em Uma Introdução aos Princípios da Moral e da Legislação p. 144 item IX: “[...] Where, then, is the line to be drawn? We shall not have far to seek for it. The business is to given an idea of the cases in which ethics ought, and in which legislation ought not (in a direct manner at least) to interfere [...]".
} 


\section{A fronteira entre ética e legislação ${ }^{52}$}

Segundo mencionado, a maneira como a legislação deve interferir na vida das pessoas é através da punição (ou por meio de recompensas em casos mais raros) ${ }^{53}$. Os eventos em que a legislação não necessita ser aplicada foram discutidos no item anterior (quando a punição é infundada, quando a punição é ineficaz, quando a punição é não proveitosa e quando não há necessidade de punição). Entretanto, pode-se observar que a ética necessita ser aplicada, em alguns dos eventos em que a legislação não deve interferir.

Será verificado neste trabalho, se há espaço para a interferência da ética nos casos quando não há nenhum espaço para a interferência da legislação. Nos episódios em que a punição é infundada (casos em que nenhum mal foi cometido) é patente que a interferência restritiva da ética também não é necessária. Isto ocorre porque não há nenhum mal no ato, ou nenhuma ofensa foi cometida ${ }^{54}$.

Há casos em que a punição se configura como ineficaz, tais casos devem ser divididos em duas classes: a primeira não diz respeito à natureza do ato, ela refere-se a uma distorção no que concerne ao momento da punição, ou seja, tal pena deveria ser aplicada em outro momento que não o da denúncia, pois é uma sentença judiciária não abrangida pela lei, no momento da acusação. Tais atos devem tanto estar sob a cobertura da legislação quanto sob a abrangência da ética através da sanção moral. No que concerne ao segundo tipo de atos aos quais a punição torna-se ineficaz, pode-se dizer que tal classe, também, não diz respeito à natureza do ato, mas sim à estranheza das circunstâncias que o acompanham. Como tais circunstâncias são incontroláveis deixam pouco ou nenhum espaço para a interferência tanto da ética quanto da legislação. Estes casos são cometidos por crianças, loucos ou bêbados ou eventos de não intencionalidade, de inconsciência, de suposições errôneas ou de impedimento físico ao exercício da

\footnotetext{
52 Vide Dias, 2007.

${ }^{53}$ Bentham, 1789, em An Introduction to the Principles of Moral and Legislation p. 144 nota I: “[...] I say nothing in this place of reward: because it is only in a few extraordinary cases that it can be applied, and because even where it is applied, it may be doubted, perhaps, whether the application of it can, properly speaking, be termed an act of legislation (...)”.

${ }^{54}$ Bentham, 1789, em An Introduction to the Principles of Moral and Legislation p. 144: "[...] In these cases it is evident, that the restrictive interference of ethics would be groundless too [...]".
} 
punição. Nestas circunstâncias, nem as normas de legislação nem as regras da ética são capazes de impedir a ocorrência destes atos ${ }^{55}$.

Os casos em que as punições são não proveitosas, não lucrativas (ou, em outras palavras, extremamente custosas) constituem o grande campo de interferência da ética, no que concerne ao agir negativo ${ }^{56}$. Quando uma punição é muito onerosa é porque o mal da punição excede o benefício auferido. $\mathrm{O}$ mal da punição se distingue em quatro campos: a) o mal da coerção, b) o mal da apreensão, c) o mal do sofrimento e d) os males derivados que atingem pessoas que estão em conexão com indivíduos que sofrem as penas acima descritas. No que concerne ao mal da coerção, apreensão e sofrimento, é possível dividir os indivíduos em dois conjuntos: a) pessoas que realmente cometeram ou estiveram prontas a cometer o mal e necessitam ser impedidas de realizar tal ato e b) indivíduos que, por apresentarem medo de ser envolvidos nos atos efetuados pelo primeiro conjunto, podem ter agido ou ter estado prontos a efetuar outros atos perniciosos.

De acordo com Bentham, somente o primeiro conjunto, pessoas que cometeram ou estiveram prontas a cometer o mal é pernicioso, e, portanto, deve ser objeto de interferência da ética (regras de ação que estejam de acordo com o princípio da utilidade). O último conjunto sendo por suposição inofensivo não deve ser objeto da ética, nem tão pouco da legislação.

A punição, então, quando aplicada ao primeiro conjunto de indivíduos, pode ser dita não proveitosa em dois sentidos: a) pela despesa que pode causar e b) pelo perigo de envolver inocentes na condenação designada ao culpado ${ }^{57}$.

O primeiro é o evento em que, dada a natureza de uma determinada ofensa, a magnitude da punição supera os ganhos auferidos por ela. Em outros termos, estas são situações em que a punição deve ser impedida. Note-se que é sempre um cálculo entre

\footnotetext{
${ }^{55}$ Bentham, 1789, em An Introduction to the Principles of Moral and Legislation p. 145: "[...] It is evident, that in these cases, if the thunders of the law prove impotent, the whispers of simple morality can have but little influence [...]".

${ }^{56}$ Vide Dias, 2007.

${ }^{57}$ Bentham, 1789, em An Introduction to the Principles of Moral and Legislation p. 145: "[...] Punishment, then, as applied to delinquency, may be unprofitable in both or either of two ways: 1. By the expense it would amount to, even supposing the application of it to be confined altogether to delinquency: 2. By the danger there may be of its involving the innocent in the fate designed only for the guilty [...]".
} 
prazer e dor, custo benefício da ação, um apelo ao primeiro princípio que determina se uma determinada punição deve ser aplicada e se as regras da ética devem interferir.

Ainda no que concerne aos eventos em que o mal causado pela punição supera o benefício gerado por ela, existem situações particulares em que a punição parece incerta ao infrator, a saber: 1) quando não há suficiente promulgação da lei, 2) devido a circunstâncias particulares em que atuam motivos sedutores e 3) pelo fato das circunstâncias poderem influenciar a sensibilidade dos indivíduos expostos à ação criminosa $^{58}$.

Quando os motivos sedutores são fortes e o agente é exposto a eles e sua sensibilidade alterada, dependendo das circunstâncias, o mal ou ofensa será cometida não importando qual a taxa da pena. A infração poderá ser punida, contudo a punição não terá utilidade para propósitos de exemplificação aos demais membros da comunidade, uma vez que a utilidade de uma punição depende da diminuição futura dos casos de delinquiência. Portanto, se esta futura punição depender de detecção que não pareça ameaçadora ou provável, especialmente, aos olhos daquele que é arrebatado pelos motivos sedutores, ela não se faz útil (constitui um custo desnecessário ao Estado). Mais uma vez é necessário ressaltar que é o cálculo de custo benefício, um apelo à utilidade instrumental do indivíduo que decide se a infração deve gerar uma norma legal.

No caso em que penas fossem aplicadas a estes eventos, haveria, então, dois males ocorrendo ao mesmo tempo, um ao lado do outro, quais sejam: o mal da ofensa e o mal da punição não havendo nenhum proveito em efetuar a pena ${ }^{59}$.

Existem casos em que a punição é considerada não proveitosa ou não lucrativa em virtude de um inocente ser envolvido ${ }^{60}$, pelo fato de haver uma dificuldade em imputar a culpa a quem é devida. Tal problema pode ocorrer devido a dois fatores: o primeiro diz respeito à má qualidade dos homens que são colocados no governo para julgar o caso e a segunda refere-se à natureza da ação. No que diz respeito à dificuldade dos governantes em imputar a culpa, esta será tanto maior, quanto maior for sua dificuldade em lidar com a linguagem. Isto ocorre porque os atos que dificultam a

\footnotetext{
${ }^{58}$ Vide Dias, 2007.

${ }^{59}$ Bentham, 1789, em An Introduction to the Principles of Moral and Legislation p. 146: "[...] Here then, will be two opposite evils running on at the same time, yet neither of them reducing the quantum of the other: the evil of the disease and the evil of painful and inefficacious remedy [...]".

${ }^{60}$ Vide Dias, 2007.
} 
imputação de culpa são difíceis de serem levados para o âmbito da legislação, sem uma complicação que dê margem a interpretações errôneas da lei ${ }^{61}$.

Considerando o exposto, em quase todas as variantes do caso em que a punição não é proveitosa (com exceção do conjunto de indivíduos que podem cometer um crime devido ao conjunto de indivíduos criminosos, conjunto b, citado), um cálculo entre custo benefício aponta para a aplicação da ética, entendida como conjunto de regras de ação capaz de zelar pela felicidade da comunidade. Em outros termos, a partir do estímulo de motivos sociais ou a partir da força da sanção moral deve ser estimulado, na comunidade, uma negação destes tipos de atos (que geram mal, mas não podem ser punidos legalmente), fazendo com que os membros de uma sociedade levem em conta o bem estar geral dela, como sendo seu próprio interesse.

Isto, em outras palavras, é o mesmo que dizer que a ética será aplicada nos casos da interação negativa entre indivíduos, apenas quando o princípio de utilidade não permitir o emprego da legislação. Ou seja, é o princípio de utilidade, através de um balanço de prazer e dor, ou custo benefício, que delimita a fronteira entre a ética e a legislação neste campo (relativo à probidade) ${ }^{62}$.

Desta forma, após a análise dos casos em que não cabe punir, mas apenas aplicar a ética, volta-se aos tipos de ações que os indivíduos podem realizar, para que a fronteira entre a ética e a legislação seja delimitada.

Conforme mencionado, os possíveis tipos de ação dos indivíduos são os seguintes: a) ação de um indivíduo que não envolve interação (denominada prudência quando gera mais prazer do que dor), b) ação de um indivíduo que envolve interações positivas (chamada beneficência ou benquerença quando ocasiona mais prazer do que dor) e c) interação entre indivíduos de forma negativa ou abstenção de geração de dor para outros (probidade quando gera mais prazer do que dor).

O grau em que a ética privada possui necessidade de intervenção da legislação é diferente no que concerne a estes três ramos, devido a um cálculo de prazer e

\footnotetext{
${ }^{61}$ Conforme mencionado ao longo deste trabalho, Bentham insiste que os legisladores ou homens públicos tomem muito cuidado com a linguagem, pois esta constitui um importante instrumento através do qual muita dor pode ser gerada, quando mal aplicado.

${ }^{62}$ Vide Dias, 2007.
} 
dor (custo benefício) das conseqüências de se colocar o aparato legislativo em funcionamento ${ }^{63}$.

De acordo com Bentham as regras que não necessitam de intervenção da legislação são as regras da prudência. O autor ressalta que só pode ser por um defeito do entendimento que um indivíduo se descuidará das regras que conduzem o próprio indivíduo à felicidade e não envolvem interações. Caso o agente cometa estes erros, isto será devido, apenas, a ele próprio e não envolverá outros indivíduos, por isso não será responsável perante a sociedade. Poder-se-ia argumentar que os homens sabem pouco sobre si mesmos e que, por este motivo, necessitam da intervenção do estado em suas vidas. O comentário de Bentham a esta questão alega que os legisladores não possuem formas eficientes de saber mais sobre os interesses dos indivíduos do que eles próprios, no que concerne a cuidados individuais tomados por estes agentes (regras da prudência), uma vez que ninguém conhece mais sobre si do que o próprio indivíduo que age ${ }^{64}$.

É apenas no que diz respeito à conduta dos indivíduos que envolve interações com outros indivíduos e que há a possibilidade de geração de dor que a legislação é capaz de intervir ${ }^{65}$. Mesmo assim, em muitas dessas ocasiões, a interferência da legislação poderá figurar objeto de disputa, conforme mostrado acima. Em diversas das situações descritas, tudo que o Estado tem a fazer é aumentar a eficácia da ética privada dando força e direção à sanção moral, que esteja de acordo com a felicidade da maioria $^{66}$, com o princípio de utilidade. Bentham argumenta com o exemplo do alcoolismo e ressalta que o estado com nenhuma chance de sucesso conseguiria extirpar o alcoolismo através da punição legal. $\mathrm{O}$ autor mostra que nem todas as torturas que a engenhosidade humana pudesse criar seriam capazes de impedir este vício ${ }^{67}$. Em diversos

\footnotetext{
${ }^{63}$ Vide Dias, 2007.

${ }^{64}$ Vide Dias, 2007.

${ }^{65}$ Bentham, 1789, em An Introduction to the Principles of Moral and Legislation p. 146: "[...] It is only with respect to those broad lines of conduct in which all persons, or very large and permanent descriptions of persons, may be in a way to engage, that he can have any pretence for interfering: and even here the propriety of his interference will, in most instances, lie very open to dispute [...] “.

${ }^{66}$ Bentham, 1789, em An Introduction to the Principles of Moral and Legislation p. 146: "[...] All he can hope to do, is to increase the efficacy of private ethics, by giving strength and direction to the influence of the moral sanction [...]".

${ }^{67}$ Bentham, 1789, em An Introduction to the Principles of Moral and Legislation p. 147: "[...] With what chance of success, for example, would a legislator go about, to extirpate drunkenness an fornication, by dint of legal punishment? Not all the tortures which ingenuity could invent would compass it: and, before
} 
dos casos mencionados, anteriormente, o Estado não deve esperar submissão à sua punição, porque antes que algum progresso fosse feito neste sentido, uma massa muito superior de males seria criada pelo exercício da punição ${ }^{68}$.

A decisão sobre manter tais casos sobre a jurisdição da legislação ou da ética passa por um cálculo de custo benefício, pela aplicação do princípio de utilidade. Toda dificuldade em tornar aplicável às normas da lei a estes casos residiria na dificuldade em determinar-se a ofensa, sem espalhar desânimo pelos motivos sociais ou motivos que unem as pessoas e as famílias.

Tudo que o governo pode fazer contra ofensas relativas a questões de prudência, questões que não envolvem interações entre indivíduos, é estimular que a sanção moral (instrumento de coação da ética) cubra os indivíduos que cometam atos contra o decoro, com uma fina censura ou com uma certa sombra de má reputação.

Bentham queria excluir a demasiada interferência dos legisladores neste ramo do agir, no escopo das ações que só dizem respeito aos próprios indivíduos, sem interações $^{69}$. A grande dificuldade, então, seria persuadir os governantes a ficarem limitados a um raio de ação em que a lei é eficiente ${ }^{70}$, para que paixões e preconceitos não façam com que os homens políticos estreitem a liberdade do sujeito, imprimindo custos à sociedade, muito superiores ao benefício que podem ser auferidos ${ }^{71}$.

De acordo com Bentham, os governantes têm o poder de transformar a vida de seus governados em um tormento, e o faziam uma vez que interferiam demasiadamente no ramo do agir que dizia respeito, apenas, aos indivíduos que não envolvem interações entre agentes, que não há a possibilidade de causar danos entre os homens. Segundo o autor, por uma questão de cálculo entre custo benefício, a

he had made any progress worth regarding, such a mass of evil would be produced by the punishment, as would exceed, a thousand-fold, the utmost possible mischief of the offense [...]".

${ }^{68}$ Vide Dias, 2007.

${ }^{69}$ Bentham, 1789, em An Introduction to the Principles of Moral and Legislation p. 147: “[...] It may be observed, that with regard to this branch of duty, legislators have, in general, been disposed to carry their interference full as far as is expedient. The great difficulty here is, to persuade them to confine themselves within bounds [...]".

${ }^{70}$ Bentham, 1789, em Uma Introdução aos Princípios da Moral e da Legislação p. 72-73: “[...] Centenas de pequenas paixões e preconceitos têm-nos conduzido a limitar a liberdade do indivíduo nesta linha, em casos em que ou não se pode esperar proveito algum da punição, ou a vantagem colhida não compensa o dispêndio feito [...]".

${ }^{71}$ Vide Dias, 2007. 
intervenção estatal não deve agir nestes casos, mas apenas regras, normas formuladas pela ética que estejam de acordo com o princípio da utilidade.

As regras que dizem respeito a interações entre indivíduos que podem ocasionar mal entre eles (probidade quando há abstenção quando não há geração do mal) são as regras que devem estar sob os cuidados da legislação. Há poucos casos em que não se pode punir alguém por cometer injúrias a alguém, mas há poucos casos em que se pode punir alguém por se auto-ferir.

No sistema de Bentham ressalta-se que a ética depende da legislação, pois primeiro estabelece-se quais ações serão cobertas pela legislação e quase todas aquelas ações que não estiverem sob o escopo da legislação pertencerão às regras da ética. Uma vez que, no que tange à probidade é necessário que se saiba quais as regras restarão sob o raio de ação da legislação para depois entender quais destas regras poderão ficar sob a determinação da ética. No que concerne ao agir que abrange interações entre indivíduos e pode ocasionar mal, é necessário um exame da legislação, para que os casos possam ser nomeados como não cabíveis às regras da legislação e então as regras da ética possam ser aplicadas.

Desta forma, com respeito à probidade, pode-se afirmar que a legislação abrange a ética privada, no sentido que dá espaço para ela existir quando não compensa ser aplicada ${ }^{72}$. É um apelo à razão calculadora que indica se determinadas ofensas devem gerar regras legais ou morais.

Do que tem sido exposto depreende-se que, no sistema de Bentham, é o princípio de utilidade que embasa a criação fictícia da legislação e a partir dos casos em que a legislação não pode existir, devido aos ditames da utilidade, há espaço para a aplicação da ética, através da sanção moral, nos casos de ofensas.

Entretanto, a legislação existe como uma maneira de garantir, coercitivamente (quando eficiente), as ações de indivíduos que concorrem com interesses da comunidade, que cometem injúrias.

Expresso de outra forma, o princípio da utilidade, explicitado como o grande princípio da moral é aplicado, diretamente, sem o auxílio de princípios secundários (o que seria diferente no caso do indivíduo teórico de Mill, pois este

\footnotetext{
${ }^{72}$ Vide Dias, 2007.
} 
recorreria a princípios secundários) para a construção de uma legislação, quando há geração de ofensas, que apenas deixará espaço para ética quando os custos punição forem maiores do que os benefícios auferidos por ela (principalmente nos casos em que a punição é dita não proveitosa $)^{73}$

Nos casos das regras de beneficências, a qualidade benéfica dos atos dependerá, principalmente, da livre disposição do agente, não constrangido por nenhuma obrigação. Desta forma, as regras de beneficência, diversamente das regras de probidade, devem ser deixadas sob escopo da ética privada, também por uma questão de eficiência. Isto ocorre porque se o Estado passar a obrigar os indivíduos a praticarem atos de bondade, podem restringir os motivos sociais da simpatia ou amor à amizade.

Os indivíduos apenas estariam moralmente ${ }^{74}$ e legalmente obrigados a salvar outro, caso uma determinada situação não ofereça riscos a ele. Em outras palavras, ações relacionadas à benevolência são aquelas efetuadas de acordo com a livre vontade do indivíduo, não constrangido pelo governo. Entretanto, a legislação pode ser estendida a este escopo, particularmente, nos casos em que uma pessoa encontra-se em perigo e os agentes podem salvá-la, sem riscos para eles.

De tudo que foi descrito, é possível concluir que a ética privada ensina como cada homem persegue sua própria felicidade, pelos motivos que oferecem a si mesmos, afetando ou não outros indivíduos. Nos eventos em que afetam outros indivíduos, ou quando há interações com outros indivíduos, é possível afirmar que a ética atuará ou não sozinha, dependendo daquilo que o princípio da utilidade prescreve, em cada situação ${ }^{75}$. A legislação, de outra parte, ensina, nos casos em que o princípio da utilidade admite sua interferência, como um grande número de homens, compondo uma comunidade, podem estar dispostos a perseguir o curso da felicidade de todos, por meio de motivos a serem aplicados pelo legislador, principalmente, no que diz respeito a impedir que os indivíduos causem mal uns aos outros.

Portanto, o campo de aplicação da ética ou do agir moral estará restrito, pela própria aplicação do princípio de utilidade (balanço de prazer e dor) às ações que não

\footnotetext{
${ }^{73}$ Vide Dias, 2007.

${ }^{74}$ É relevante entender que esta obrigação moral não possui a força coercitiva da lei. Entretanto, deve-se ter em vista que a sanção moral também é um importante instrumento de coação, para fazer com que as ações dos indivíduos concordem com o princípio de utilidade.

${ }^{75}$ Vide Dias, 2007.
} 
envolvem interações entre indivíduos (prudência), ao agir com o outro a fim de proporcionar prazer (beneficência) e para salvaguardar a felicidade dos indivíduos (probidade) nos casos em que o balanço de prazer e dor indica a não intervenção da lei ou a não punição ${ }^{76}$.

A partir da análise feita a respeito das regras que constam na ética e na legislação é possível concluir que não há diferença de natureza no conteúdo de ambas as regras. É a análise de custo-benefício (prazer e dor), um apelo ao princípio de utilidade que prescreve as normas que devem constar na ética ou na legislação, que separa os raios de ação de uma e de outra, sem que critérios adicionais (ou princípio secundários) ao princípio de utilidade precisem ser criados pelo autor, para que os limites entre a ética e a legislação sejam estabelecidos ${ }^{77}$.

De todo o exposto conclui-se que, há no utilitarismo de Bentham, um cálculo que efetua um balanço entre prazeres e dores com a finalidade de apontar, em primeiro lugar se as normas pertencerão à ética ou à legislação. Em segundo lugar, quando fica decido, pelo uso da razão calculadora que as regras devem pertencer ao campo da moral, o indivíduo continuará a efetuar um cálculo a cada ação uma vez que o indivíduo teórico de Bentham age dotado de apenas um princípio, a saber: o princípio de utilidade.

Toda a moralidade dos costumes será sempre questionada e avaliada a cada ação conforme um balanço entre prazer e dor formulado pelo indivíduo que age. Desta maneira de agir inerente ao indivíduo teórico de Bentham, derivada do apelo constante ao primeiro princípio, deduzido da natureza humana instrumental do indivíduo teórico de Bentham, tem-se que o espaço para regras morais fica reduzido, uma vez que este indivíduo, no momento da ação, sempre efetuará um balanço entre prazer e dor, ainda que este cálculo leve em conta toda a complexidade da racionalidade exposta anteriormente do balanço entre prazer e dor (que acompanha sete circunstâncias como intensidade, proximidade, longinquidade do prazer e da dor, etc). Será mostrado no capítulo terceiro, como o indivíduo moral de Mill será mais complexo do que o de Bentham e, no campo da ética, a natureza deste novo indivíduo dará origem a um

\footnotetext{
${ }^{76}$ Vide Dias, 2007.

${ }^{77}$ Ibid.
} 
princípio da utilidade também mais complexo e como decorrência a uma mais complexa ética utilitarista que permitirá que este indivíduo aja de acordo com princípios secundários e, portanto, não precise fazer um apelo ao princípio de utilidade a cada ação como se fosse um homem parecido a uma máquina de fazer cálculos (metáfora para razão calculadora).

Em outras palavras, a natureza mais complexa do indivíduo teórico de Mill dá origem a um princípio de utilidade mais complexo que permite a elaboração de um maior número de regras morais ou de uma moralidade positiva propriamente, com regras secundárias, embasadas no preceito que é correto buscar o prazer e que é correto fugir da dor, mas que o indivíduo possa agir no campo da prática dotado de uma moralidade costumeira como não matar, não roubar, não mentir, etc. Em outras palavras, a mais complexa natureza humana do indivíduo teórico de Mill propicia a elaboração de um maior número de regras morais quando comparado ao utilitarismo de Bentham.

Ora, da natureza humana do indivíduo teórico de Bentham foi possível depreender uma racionalidade calculadora que conduz o indivíduo para o mundo prático, o leva a agir dotado apenas do princípio de utilidade (que é correto buscar o prazer e errôneo buscar a dor) e questiona todas as demais regras morais no momento da ação, não deixando nenhum espaço para uma moralidade positiva, com outros componentes ou regras para além do princípio da utilidade.

Tendo em vista este contraste entre ambas as moralidades de ambos os autores, prossegue-se à elaboração do modelo de indivíduo teórico de Mill, ou da natureza humana do indivíduo teórico de Mill, do princípio de utilidade deste autor e a possibilidade de elaboração de um maior número de regras morais quando comparado ao utilitarismo de Bentham. Ou em outros termos, a possibilidade da ampliação do espaço da moral no utilitarismo de Mill quando comparado ao utilitarismo de Bentham. 


\section{Capítulo II- Os Autores que mais influenciaram Mill no que diz respeito à Ética}

Este capítulo tem por objetivo mostrar quais foram as principais influências nos escritos de John Stuart Mill, no que concerne aos seus escritos sobre Ética, bem como contar um pouco como foi sua impressão subjetiva retratada na Autobiografia no que concerne à rígida educação intelectual que recebeu e à pouca presença de afeto dada pela principal pessoa que o acompanhava; seu pai (James Stuart Mill). Estes elementos são de fundamental importância a serem aqui tratados, pois no que se refere às influências intelectuais pode-se afirmar que constituirão a fonte de onde ele formará sua maneira de pensar e elaborar raciocínios; quanto ao modo como foi educado e sua decorrente crise mental ressalta-se que são constituintes importantes de sua história de vida que o fizeram repensar, profundamente, o significado de quais eram os constituintes da natureza humana, bem como aquilo que os homens perseguiam para serem felizes ${ }^{78}$. No que concerne ao seu pensamento é fundamental efetuar a leitura de vida deste autor, pois trata-se de um psicologista, associacionista. Sua segunda lei da mente que diz respeito às leis de associação elencam que idéias similares tendem a se provocar umas às outras. De acordo com a segunda dessas leis, quando duas impressões foram freqüentemente experimentadas (ou mesmo pensadas), simultaneamente ou em sucessão imediata, então, sempre que uma dessas impressões, ou a idéia correspondente, retorna, a idéia da outra tende a ser provocada. Isto significa que tanto as leituras que fez como algumas experiências fundamentais em sua vida (como sua crise mental) resultarão em seus escritos, no que ele se tornou e produziu como filósofo, sendo que disto extrai-se a construção de seu modelo de indivíduo e como decorrência sua moralidade.

Em outras palavras, as causas que levaram Mill a formar seu modelo de indivíduo e tornar mais complexo o modelo de indivíduo teórico de Bentham foram; seu maior aprofundamento no que diz respeito ao conhecimento da história da filosofia,

\footnotetext{
${ }^{78}$ Será mostrado adiante que Mill, em uma primeira leitura de Bentham, acolherá o princípio de utilidade descrito por Bentham, derivado de uma natureza humana simples, calculadora que busca o prazer e foge da dor, após sua crise mental, se afastará do modelo de homem de Bentham de uma maneira radical em seu ensaio de 1838 e voltará a reconciliar-se com o seu princípio de utilidade, mas acrescentando diversos elementos à natureza humana ressaltada por Bentham e tornando a maximização da felicidade um conceito mais preenchido do que para Bentham, utilizando-se, por exemplo, de mais regras morais no âmbito da moralidade, possibilidade apenas plausível, porque o indivíduo teórico de Mill é mais complexo.
} 
relativamente à Bentham, bem como sua crise mental que o fez questionar que os componentes da natureza humana não poderiam ser apenas uma racionalidade calculadora fria, calculadora que efetuaria sempre um cálculo entre o prazer e a dor. Essas foram as motivações de Mill a primeiro aceitar o utilitarismo quando leu o Traité de Legislatión de Bentham e depois quando repensou o sistema teórico de Bentham e criou um novo modelo de indivíduo dotado das leis da mente (especialmente a lei de associação), principalmente, da tese hedonista de busca do prazer e fuga da dor, mas também dotado de subteses subordinadas à tese hedonista, como o princípio da natureza humana do hábito, faculdades mais elevadas que uma vez ativadas não se satizfazem com prazeres de qualidade inferiores e a capacidade de melhorar ao longo do tempo.

Em outras palavras, as motivações de Mill para que ele se tornasse um utilitarista mais complexo em relação a Bentham podem ser explicadas tanto do ponto de vista de uma leitura genética, através do auxílio do livro Atutobiografia, com o subsídio de elementos marcantes que ocorreram em sua vida como o estudo e a exposição a uma ampla e diversificada história da filosofia, bem como ao fator relativo à escassez de afeto, um dos elementos que levaram a sua crise mental. Por estas causas genéticas, aliada ao seu método de realizar ciência social é possível entender porque Mill motivou-se a cogitar possíveis novos elementos à natureza humana do indivíduo e o sistema teórico, ancorado em toda tradição filosófica que havia lido, confirmou a percepção que sua crise mental deixara de que o modelo de indivíduo, assim compreendido por este autor, de fato seria mais complexo do que o modelo de indivíduo teórico de Bentham.

O modelo de indivíduo teórico de Mill que enuncia como tese principal a tese hedonista de que o homem busca o prazer e foge da dor agora terá outros elementos anexados a esta tese como a questão do hábito (ou seja, em sua origem o indivíduo escolhe uma determinada ação porque é prazerosa, mas com o passar do tempo, o indivíduo assimila o fato da ação ser prazerosa, benéfica e passa a agir por hábito), outro aspecto está relacionado ao indivíduo possuir faculdades mais elevadas que apenas satisfazem-se com prazeres mais elevados, uma vez ativadas estas faculdades o indivíduo não troca os prazeres mais elevados por prazeres menos elevados, por prazeres iguais aos de animais inferiores, um terceiro elemento da natureza humana está relacionado ao fato do indivíduo possuir uma capacidade de melhorar ao longo do tempo, em outras palavras, 
o modelo de indivíduo é dinâmico e não estático, o indivíduo aprende e desenvolve-se com o tempo, incluindo suas ações e regras morais, conforme a experiência demonstra ser benéfico (por isto esta regra também é subordinada ao princípio de utilidade, pois a capacidade de melhorar ao longo do tempo tem a ver com trazer benefícios ao longo do tempo para o indivíduo). Além disso, o indivíduo ainda possui leis complexas da mente, como a lei de associação acima elencada; que querem dizer que idéias similares tendem a provocarem-se umas às outras.

Todas essas conclusões sobre o modelo de homem de Mill, sobre seu modelo de natureza humana, que serão demonstradas ao longo deste trabalho podem ser utilizadas para entender porque o próprio Mill construiu este modelo de homem, dado que Mill é um homem.

Considerando que Mill é um homem ele possui as características que ele mesmo detalha em seu modelo de homem, a saber: que ele busca a felicidade (o prazer e foge da dor), que ele possui faculdades mais elevadas que de fato foram ativadas pela leitura de inúmeras obras históricas, filosóficas, entre outras (e que ele não trocaria esta vida por nenhum tipo de vida inferior, como a vida de prazeres de animais com capacidade racional inferior), que ele possui a capacidade de se aprimorar ao longo do tempo e de, inclusive, modificar de opiniões conforme o tempo transcorre; sendo que, de fato isto pode ser observado, uma vez que ao ler Bentham pela primeira vez tornou-se um utilitarista sem críticas e após sua crise mental, no ensaio de 1838 tornou-se um ferrenho crítico de Bentham a respeito de sua visão sobre a natureza humana. Após esse período reconcilia-se, parcialmente (acrescentando elementos a esta natureza), com a visão utilitarista de Bentham, sendo esta, mais uma demonstração da natureza humana de que o indivíduo pode modificar-se, aprimorar-se ao longo do tempo. Além disso, Mill também agia por hábito, a Autobiografia é um excelente registro para demonstrar que Mill agia por hábito, disciplina do estudo, inclusive no que diz respeito às suas ações morais, não parecia ser do tipo que realiza cálculos a todo instante para, então, ver o que lhe aprazia, desta forma, parecia mais ter rígidos princípios secundários morais (derivados do princípio primeiro, princípio de utilidade) que regiam sua conduta. Ademais, leis da mente como a associação de idéias; "que idéias similares tendem a provocarem-se umas às outras" parecem ser uma constante em seu trabalho, uma vez que diversas idéias que 
formulava a partir de impressões através de leitura das mais variadas bibliografias geravam idéias semelhantes que acrescentava em seus próprios escritos, como o fato de que adicionou da física o método para explicar o comportamento do ser humano como uma complexidade de causas (composição de causas) que pode ser inclusive conflitante assim como o é o cálculo da gravitação (um exemplo disto é que ao mesmo tempo em que Mill nutria afeto por seu pai ele não gostava das limitações que seu pai possuía para lhe fornecer afeto e mesmo para compreender um ser humano afetivo ${ }^{79}$ e isto não constitui uma contradição lógica, mas antes uma complexidade de causas que devem ser utilizadas para compreender os sentimentos de Mill relativamente a seu pai).

Portanto, dadas as motivações de uma leitura genética para entender porque Mill tornou-se um utilitarista mais complexo relativamente a Bentham, como sua maior imersão na história da filosofia, bem como com sua crise mental que o fez estudar poesia e perceber que o ser humano talvez não fosse apenas composto de uma razão calculadora, assim como a construção de seu modelo de homem que uma vez formulado por ele, pode ser utilizado para entender qualquer homem, incluindo o próprio John Mill, dado que John Mill era homem. Das características universais de todo homem, a saber: leis da mente como a lei de associação de idéias, a tese central hedonista: busca do prazer e dor, subteses acopladas à tese hedonista como: agir por hábito, capacidade de melhorar ao longo do tempo e faculdades mais elevadas ativadas por prazeres mais elevados. É possível entender o caminho que Mill trilhou para formular sua teoria moral, mais especificamente, para provar a tese que se quer sustentar aqui, a saber: que é possível haver a ampliação do espaço da moral no seu utilitarismo, quando comparado à moral do utilitarismo de Bentham.

Tendo em vista o exposto apresenta-se a temática deste capítulo.

No que diz respeito ao mote deste capítulo, será possível verificar que as influências nos escritos de Mill foram inúmeras, entretanto, dar-se-á ênfase aos autores sobre os quais parecem ter sido pontos de inflexão para formação da teoria moral de John Stuart Mill. É fato que seu pai e sua esposa foram influências constantes e de valores inestimáveis para a formação de toda a sua obra, assim como ele relata em sua Autobiografia, entretanto, pretende-se aqui tratar da influência de autores em que o

\footnotetext{
${ }^{79}$ Lembrando que sentimentos são descritos por Mill como sendo estados mentais.
} 
alcance para a formação de sua filosofia moral foi constatado a partir dos seus escritos. Como é o caso de seus escritos sobre Bentham e Comte, por exemplo. Defende-se ainda que houve uma forte influência de autores antigos (como Aristóteles) sobre os escritos de John Stuart Mill, conforme o próprio autor relata (quando menciona o impacto da Retórica para a formação de sua teoria moral), tornando-se importante fonte de formação de sua teoria moral, entretanto, assume-se que toda tese de doutorado tem limites circunscritos por uma problemática. Esta tese não pretende tratar das influências dos autores antigos nos escritos de Mill, dado que se considera que a busca de evidências para corroborar as conexões dos escritos de Mill com autores antigos seria tema para uma tese de doutorado adicional.

Tendo em vista estas considerações gerais sobre o capítulo, dividir-se-á o mesmo em duas seções: a) a primeira constituirá uma Visão Geral das Influências Teóricas de Mill e um breve relato sobre sua vida e b) a segunda será a respeito da mudança de visão de Mill relativamente à filosofia de Bentham, devido a sua experiência pessoal e suas influências teóricas retratadas no tópico primeiro.

\section{Uma Visão Geral das Influências Teóricas de Mill}

Muitos autores influenciaram John Stuart Mill, dado que ele foi educado em uma disciplina intelectual rígida conduzida por seu pai James Stuart Mill. Em outras palavras, quase toda sua educação, os livros que lhe eram entregues eram escolhidos e doados por seu pai até que ele atingisse a idade adulta. Com a idade de três anos ele começou a aprender grego e o autor descreve em seu livro Autobiografia que ele quase não podia lembrar-se do primeiro livro que leu, uma vez que leu em uma idade bastante precoce $^{80}$. O livro foi as Fábulas de Esopo ${ }^{81}$, o segundo foi Anabase de Xenofonte. Com a idade de oito anos John Stuart Mill havia lido um amplo número de autores Gregos, em prosa, dentre os quais estão Xenofonte e Heródoto, mas desta vez com os livros a

\footnotetext{
${ }^{80}$ Mill, 1873, p. 28.

${ }^{81}$ Esopo viveu no século VI a.c., foi um dos fundadores da prosa como meio de criação artística; tal feito repercutiu na literatura romana e em toda literatura ocidental. Esopo escreveu um grupo de fábulas (358) que se denominam Fábulas de Esopo. São textos de moral popular cujos personagens são animais que conversam como homens. Representam fundamental importância para entender a vida cotidiana dos gregos.
} 
${ }^{82}$ Ciropédia e As Memórias de Sócrates, leu também algumas Vidas de Filósofos ${ }^{83}$ de Diógenes Laércio, parte de Luciano e o Discurso a Demonico e o Discurso a Nícocles, ambos de Isócrates e parte de Tucidídes. Em 1813, Mill ${ }^{84}$ leu os primeiros seis diálogos de Platão, na ordem costumeira ${ }^{85}$, de $\hat{\text { Eutifron }}{ }^{86}$ há Teeteto $^{87}$, mas o autor ressalta que este último poderia ser omitido, uma vez que naquele momento, era simplesmente impossível ser entendido.

Em sua infância e primeira educação John Stuart Mill leu obras históricas de Robertson $^{88}$, leu Hume ${ }^{89}$ e Gibbon $^{90}$, mas o seu maior prazer era ler obras de Watson ${ }^{91}$ sobre os reinados de Felipe II e Felipe III. Mill descreve que a heróica defesa dos cavaleiros de Malta contra os turcos e a revolta dos Países Baixos contra a Espanha despertou no autor um interesse intenso e duradouro ${ }^{92}$. Depois de Watson, sua leitura favorita era a História de Roma, de Hooke ${ }^{93}$. Ainda no que diz respeito aos livros de história, Mill leu os últimos dois ou três volumes da tradução da História Antiga de

\footnotetext{
${ }^{82}$ A Ciropédia é um romance político que descreve a educação de um líder educado para reinar como uma espécie de déspota benevolente (ao menos no livro 8).

${ }^{83}$ Obra composta de dez livros contêm relevantes informações sobre a divulgação das diversas escolas de pensamento da filosofia grega

${ }^{84}$ Sempre que eu utilizar a palavra Mill estarei referindo-me ao filho (John Stuart Mill e não ao pai James Stuart Mill)

${ }^{85}$ Outros comentadores classificam os diálogos de Platão em outra ordem, mas Mill os classificou assim em sua Autobiografia.

${ }^{86}$ Diálogo cujo tema principal era a piedade e impiedade, Mill muito precocemente já estava sendo introduzido em questões de âmbito moral

${ }^{87}$ O principal tema deste Diálogo refere-se à teoria do conhecimento.

${ }^{88}$ William Robertson foi um historiador que escreveu a História da América em dois volumes nos quais ele narra fatos sobre a descoberta do novo mundo. Para tanto, ele partiu de fatos relatados por outros historiadores e acrescentou novos fatos a estes.

${ }^{89}$ Influência fundamental para que Mill formasse as leis da mente da natureza humana de seu indivíduo, será tratado mais à frente.

${ }^{90}$ Historiador inglês escreveu sua principal obra; A História do Declínio e Queda do Império Romano. Notável obra pelas informações contidas, talvez seja a única a resistir após o século XIX, depois das descobertas arqueológicas e documentais realizadas. Gibbon trata a decadência do império como um processo contínuo. A primeira parte de sua obra retrata um período de 460 anos (por volta de 180 a 641d.C) e a segunda cobre o período até a queda de Constantinopla. Uma crítica que alguns historiadores fazem a ele, refere-se ao fato de que Gibbon não faz muitas referências ao contexto econômico para explicar a queda do império, contudo, este tipo de referência não era comum em obras de historiadores de seu período.

${ }^{91}$ Robert Watson escreveu A História do Rei Felipe II e ao que parece escreveu outros livros aos quais não tive acesso.

${ }^{92}$ Mill, 1873, p. 29.

${ }^{93}$ Penso que Mill está referindo-se a Hook N. que escreveu The Roman History from the building of Rome to the Ruin of the Commowealth.
} 
Rollin $^{94}$ que começava com Felipe da Macedônia. No que diz respeito à história inglesa posterior ao período tratado por Hume, o autor relata haver lido a História de nosso tempo, de Burnet ${ }^{95}$, embora admita que pouco se tenha interessado por este livro. Além disso, ele teve contato, em uma idade bastante precoce, com obras como a Visão histórica do governo inglês de Millar ${ }^{96}$, a História Eclesiástica, de Mosheim ${ }^{97}$, a Vida de John Knox ${ }^{98}$, de M'Crie e até a História dos Quakers, de Sewell e Rutty. O pai de John Mill, James Stuart Mill, tinha um certo apreço por colocar nas mãos de Mill, livros que apresentavam homens de energia que fossem capazes de enfrentar circunstâncias extraordinárias, de lutar contra as dificuldades e superá-las ${ }^{99}$ [MILL, 1873, p. 30]. De trabalhos deste tipo o autor recorda-se das Memórias Africanas, de Beaver ${ }^{100}$, e do relato de Collins a respeito dos primeiros colonos de New South Wales. Raramente, Mill tinha acesso a livros infantis, exceto quando ocorria de ser presenteado com tal tipo de livro, entre tais exemplos destes livros, ele teve Robison Crusoé ${ }^{101}$. De acordo com Mill, não foi parte do sistema de educação de seu pai excluir livros de diversão, embora ele os permitisse, muito raramente. De tais livros seu pai pediu vários emprestados como: As

\footnotetext{
${ }^{94}$ Charles Rollin foi historiador francês que rendeu importantes serviços, entre outros, ao estudo da história grega.

${ }_{95}$ Autor escocês iniciou sua obra History of my Own Time em 1683, cobrindo a guerra civil inglesa entre parlamentares e partidários da coroa (entre 1642-46, segunda 1648-49, terceira 1649-51) apoiada pelo Rei Charles I e depois por Charles II contra os partidários do parlamento inglês, relatando também o Commonwealth da Inglaterra e o tratado de Utrecht de 1713.

${ }^{96} \mathrm{John}$ Millar escreve sobre uma visão histórica do governo inglês deste a chegada do estabelecimento dos saxões na Inglaterra até a Revolução de 1688.

${ }^{97}$ De acordo com Mosheim A História Eclesiástica abrange o período que vai do nascimento de cristo até o século XVIII, abarca o nascimento, variações e o progresso da igreja, consideradas em conexão com o estado do conhecimento da filosofia e da história política da Europa durante aquele período.

${ }^{98}$ John Knox foi um clérigo escocês e líder da reforma protestante, foi educado na Universidade de St Andrews. Juntou-se ao movimento de reforma na igreja escocesa.

${ }^{99}$ Além disso, James Mill apresentava a John Mill as próprias circunstâncias extraordinárias através dos livros de história, conforme mostrou-se acima.

${ }^{100}$ Era um capitão que escreveu o livro African Memoranda relativo à colonização da costa oeste da África no ano de 1792, relatando as tribos que lá estavam, a produção do solo, a facilidade de colonização daquela parte da África no que concerne ao cultivo da terra e à introdução da religião aos seus habitantes, bem como, meios de introduzir gradualmente a abolição da escravidão.

${ }^{101} \mathrm{O}$ famoso romance de Daniel Defoe é inspirado na história verídica de um marinheiro escocês Alexander Selkirk, abandonado, a seu pedido, numa ilha onde viveu apenas de 1704 a 1709. Robison Crusoé toma desta história verídica o mito da solidão, na medida em que, depois de um naufrágio de que é o único sobrevivente, vive sozinho, durante cinco anos até encontrar a personagem sexta-feira. $\mathrm{O}$ romance simboliza a luta de um homem solitário contra a natureza, a tentativa de reconstituição de rudimentos da civilização humana, dependente apenas de sua força.
} 
mil e uma noites ${ }^{102}$, os Contos árabes, de Cazotte ${ }^{103}$, Dom Quixote ${ }^{104}$, Os Contos populares, de Miss Edgeworth ${ }^{105}$.

De seus oito anos aos seus doze ${ }^{106}$, os livros em latim que Mill lembra ter lido foram as Bucólicas ${ }^{107}$ de Virgílio e os seis primeiros livros da Eneida ${ }^{108}$, toda a obra Horácio, exceto os Epodos, as Fábulas de Fedro ${ }^{109}$; todo Salústio ${ }^{110}$, uma parte considerável das Metamorfoses ${ }^{111}$, de Ovídio, algumas peças de Terêncio, dois ou três livros de Lucrécio ${ }^{112}$, vários discursos de Cícero, de seus escritos sobre oratória. Em grego, Mill leu a Ilíada ${ }^{113}$ e a Odisséia ${ }^{114}$ inteiras, uma ou duas peças de Sófocles ${ }^{115}$, Eurípides ${ }^{116}$ e Aristófanes ${ }^{117}$, ainda que admita ter aproveitado pouco delas, lera aos oito

\footnotetext{
${ }^{102}$ É de amplo conhecimento que As Mil e uma Noites é uma coleção de histórias e contos populares originárias do Oriente Médio e do Sul da Ásia, passando a ser amplamente conhecida a partir da tradução para o francês. A história inclui o folclore indiano, persa e árabe. O que é invariável na obra é que nas distintas versões os contos estão organizados como uma série de histórias narradas por Xerazade, esposa do rei Xariar. Este rei, louco por haver sido traído por sua primeira esposa, desposa uma noiva diferente a cada noite, mandando-as matar no dia seguinte. Xerazade consegue escapar a este destino, por contar histórias maravilhosas sobre diversos temas que captam a curiosidade do rei.

${ }^{103}$ Autor francês escreveu um grande número de estórias orientais tais como Mille et une fadaises, Contes a dorme debout (1742).

${ }^{104}$ Dom Quixote de La Mancha, do escritor Miguel de Cervantes. O livro parodiou romances de cavalaria. O protagonista, já em certa idade, entrega-se à leitura desses romances e perde o juízo, acreditando que tenham sido historicamente verdadeiros e decide tornar-se um cavaleiro andante. Parte mundo afora, acompanhado de Sancho pança no seu burrico, vivendo seu próprio romance de cavalaria. Por meio de Dom Quixote, Cervantes narra e satiriza os preceitos que regiam as histórias fantasiosas dos heróis de cavalaria.

${ }^{105}$ Maria Edgeworth, escritora de Oxfordshire escreve contos sobre, por exemplo, relações de afeto familiares camponeses.

${ }^{106}$ Mill, 1873, p.32.

${ }^{107}$ A primeira frase da advertência das Bucólicas de Virgílio é a de que ele escreverá um poema que tem por objeto celebrar os amores, os prazeres e as disputas dos pastores; ou seja a imitação da vida pastoril, representada com todos os seus encantos. Ressalta que não disputará se realmente tais pastores foram felizes como se pinta

${ }^{108}$ De uma forma muito resumida coloca-se que a Eneida é um poema épico em latim que canta a glória e o poder de Roma, através da saga de Enéias cujo destino era ser o ancestral de todos os romanos.

${ }^{109}$ Fedro enriqueceu estilisticamente muitas fábulas de Esopo, sendo introdutor da fábula na literatura latina, redigia suas fábulas, normalmente, sérias ou satíricas tratando das injustiças, dos males sociais e políticos, expressando atitudes dos fortes e oprimidos.

${ }^{110}$ Escritor e poeta da literatura latina. Possui alguns escritos, inclusive sobre vícios e virtudes.

${ }^{111}$ Poema inconcluso, há comentadores que defendem a tese de que mostra o mundo em constante mutação.

${ }^{112}$ Poeta e filósofo latino acreditava que o epicurismo poderia garantir a felicidade humana.

${ }^{113} \mathrm{O}$ poema narra os acontecimentos e mitos que compõem o período final da guerra de Tróia.

${ }^{114}$ A Odisséia é um poema que de certa forma é uma continuação da Ilíada.O poema narra a longa viagem do herói grego Odisseu para casa (Ítaca), após a queda de Tróia.

${ }^{115}$ Dramaturgo grego, escritor de tragédia, dentre elas está Antígona (discute questões de justiça), Édipo Rei (clássico que foi trazido para a psicanálise contemporânea) e Édipo em Colono.

${ }^{116}$ Considerado o último dos grandes autores trágicos de Atenas Clássica, foi também dramaturgo grego.

${ }^{117}$ Dramaturgo grego, redator de comédias, entre outras, escreveu a peça na qual satiriza os filósofos, entitulada: “As Nuvens”.
} 
anos todo Tucídides ${ }^{118}$, as Helênicas, de Xenofonte, Demóstenes ${ }^{119}$, Esquines e Lísias (ambos os últimos também eram oradores gregos), Teócrito ${ }^{120}$ e Anacreonte. Mill relata ter lido também vários livros de Políbio ${ }^{121} \mathrm{e}$, finalmente, ressalta haver estudado a Retórica de Aristóteles que parece ter sido um ponto de inflexão para ele nos seus estudos referentes à filosofia moral, uma vez que este livro teria sido o primeiro tratado expressamente científico em qualquer assunto moral ou psicológico que ele havia tido contado.

\begin{abstract}
"[...] a retórica de Aristóteles ${ }^{122}$ que por ser o primeiro tratado expressamente científico que eu lia sobre assuntos morais e psicológicos e por conter muitas das melhores observações dos antigos sobre a natureza humana e sobre a vida, meu pai me fez estudar com cuidado especial, pedindome para resumir a matéria em quadros sinóticos[...]" [Mill, 1873, p. 32].
\end{abstract}

Durante estes mesmos anos, Mill descreve em sua Autobiografia ${ }^{123}$ que aprendeu a fundo Geometria elementar e Álgebra, embora a história continuasse sendo o assunto preferido do autor, sobretudo a história antiga. Outro autor de história que Mill lia continuamente era Mitford ${ }^{124}$ e o título era História da Grécia, embora Mill ressalte

\footnotetext{
${ }^{118}$ Historiador da Grécia antiga, escreveu sobre a História da Guerra do Peloponeso, em que em oito volumes conta a guerra entre Esparta e Atenas.

${ }^{119}$ Importante orador e político grego, sua oratória representa importante expressão intelectual da Atenas antiga. A vida como orador e político foi dedicada à defesa de Atenas que se via ameaçada por Felipe II da Macedônia. Contra o líder da Macedônia, Demóstenes escreveu inúmeros discursos para arregimentar cidadão atenienses contra a Macedônia, tais discursos ficaram conhecidos como Filípicas.

${ }^{120}$ Escritor grego escreveu principalmente poemas bucólicos e contos gregos.

${ }^{121}$ Foi um geógrafo e historiador do mundo mediterrâneo. É dito ser um dos primeiros historiadores a tratar a história como uma sequiência lógica de causas e efeitos. Sua obra baseia-se numa vivacidade crítica das fontes existentes e da tradição descrevendo com intensidade os acontecimentos e as causas que ele, inclusive, presenciou.

${ }^{122}$ A Retórica de Aristóteles, segundo descrito na introdução de João Volquim, não é prática, ou seja, não influi no comportamento geral da vida; nem é teorética, isto é, não tem por objeto a essência. É poética, visto que formula as regras de criação. Enfim, sua finalidade não é tanto persuadir quanto descobrir o que há de persuasivo em cada caso. A Arte da Retórica de Aristóteles compreende três livros, sendo que o segundo livro dos capítulos I a XVII compreendem as provas morais da retórica. É, provavelmente a estes ensinamentos morais a que Mill está referindo-se quando leu a retórica.

${ }^{123}$ Mill, 1873, pp. 32-33.

${ }^{124}$ Historiador inglês, nasceu no século XVIII e morreu no século XIX.
} 
que seu pai o alertava para o fato de que este autor deveria ser lido com certo cuidado, uma vez que deturpava fatos para restabelecer déspotas e caluniar as instituições populares. Alertando Mill sobre estas questões, seu pai conseguiu fazer com que as opiniões de Mill fossem sempre contrárias às do autor. Entretanto, Mill argumenta que continuava tendo imenso prazer ao ler o livro. A história romana também constituía interesse de Mill, tanto na versão de Hooke, como na versão de Ferguson ${ }^{125}$. Um exercício voluntário ao qual Mill muito se afeiçoou durante toda sua infância, consistia em escrever histórias, o autor compôs sucessivamente uma história romana, extraída de Hooke e uma história da Holanda, baseada em um de seus favoritos, a saber: Watson. Dos onze aos doze anos passou a escrever histórias que dizia serem mais sérias; uma história do governo romano, compilada (com a ajuda de Hooke) e de Tito Lívio ${ }^{126}$. Era um relato das lutas entre patrícios e plebeus, assunto que absorvia seu interesse; o autor defendia as Leis Agrárias, guiado pelas explicações de seu pai e baseando-se no testemunho de Tito Lívio. Alguns anos depois, desprezando seus esforços infantis, o autor destruiu todas as suas histórias, sem perceber que mais tardiamente poderia desejar relê-las ${ }^{127}$. Até então Mill relata haver lido pouca poesia que não fosse clássica, o autor havia lido - Shakespeare -, sobretudo, por se tratar de dramas históricos, passando subseqüentemente, a outras peças. Seu pai interessava-se pouco por poetas ingleses, salvo Milton $^{128}$, por quem tinha grande admiração, e também não tinha muito apreço pela poesia do século XIX, exceto pelos romances em verso de Walter $\operatorname{Scott}^{129}$ que leu com narrativas animadas. Os Poemas de Dryden estavam entre os livros de seu pai, entretanto, Mill relata que nunca se interessou por nenhum deles, exceto a Festa de Alexandre que

\footnotetext{
${ }^{125}$ Este último penso ser Adam Ferguson (também nasceu no XVIII e faleceu no XIX), foi filósofo, cientista e historiador. Escreveu Um Ensaio sobre a História da Sociedade Civil. Este ensaio parte de uma explicação das características gerais da natureza humana, para então descrever como os indivíduos relacionam-se no estado de natureza, mostra o princípio de auto-preservação dos indivíduos e como decorre o princípio de união entre eles, fala do princípio de guerra entre os indivíduos, dos poderes intelectuais, dos sentimentos morais e por fim aborda o tema da felicidade. É possível afirmar que este autor segue um modelo geométrico de explicação da sociedade. Será visto mais adiante que tanto o modelo geométrico de raciocínio, quanto noções como estado de natureza não compõem, respectivamente, o método e o modelo de explicação da sociedade de Mill.

${ }^{126}$ Historiador que narra a história de Roma desde o momento tradicional de sua fundação até o início do século I.

${ }^{127}$ Mill, 1873, p. 34

${ }^{128}$ John Milton foi um poeta inglês, mais conhecido pelo seu poema épico denominado Paradise Lost.

${ }^{129}$ Romancista e poeta escocês do século XVIII-XIX.
} 
como várias baladas de Walter Scott, Mill relata que costumava cantar interiormente com sua própria música.

De Dryden: Alexander's Feast; or the Power of Music

A song in Honour of St.Cecilia`s Day, 1697.

T'was at the royal feast for Persia won

By Philip's warlike son:

A loft in awful state

The godlike hero sate

On his impartial throne;

His valiant peers were placed around;

Their brows with roses and with myrtles bound:

(So should desert in arms be crowed).

The lovely Thais, by his side,

Sate like a booming Eastern bride,

In flower of youth and beauty's pride.

Happy, happy, happy pair!

None but the brave,

None but the brave,

None but the brave deserves the fair.

Chorus

Happy, happy, happy pair!

None but the brave,

None but the brave,

None but the brave deserves the fair

Adicionalmente a estes poemas descritos por Mill, o autor leu os breves poemas de Cowper ${ }^{130}$, entretanto, o autor descreve, em seu livro Autobiografia que nunca avançou muito nos poemas mais longos e nada o interessou tanto nos dois volumes como na narração em prosa. Quando Mill tinha treze anos leu os Poemas de Campbell, entre os quais Lochiel, Hohenlinden, $O$ exilado de Erin [Exile of Erin] ${ }^{131}$ e alguns outros que

\footnotetext{
${ }^{130}$ Cowper foi um poeta inglês que descreveu cenas da vida rotineira e do interior da Inglaterra em seus poemas.

${ }^{131}$ Exile of Erin: "There came to the beach a poor Exile of Erin,

The dew on thin robe was heavy and chill:

For this country he sigh'd, when at twilight repairing

To wander alone by the wind-beaten hill.

By the day-star attracted his eye's sad devotion,

For it rose o'er his own native isle of the ocean,

Where once, in the fire of his youthful emotion,

He sang the bold anthem of Erin go bragh.
} 
deram a ele sensações que ele nunca havia experimentado antes, conforme descreve na Autobiografia [Mill, 1873, p.36].

Mill descreve em seu livro Autobografia que não extraía muito dos poemas mais longos, exceto pela leitura do poema Gertrude de Wyoming ${ }^{132}$, que manteve um lugar em seus sentimentos como a perfeição do pathos $^{133}$. É importante notar que a partir da leitura de poemas Mill começava a descobrir a relevância de se estimular os sentimentos e não apenas uma mente analítica.

Outra atividade que perdurou durante boa parte de sua infância foi a ciência experimental, não a partir da elaboração de experimentos, mas meramente lendo a respeito deles. Mill descreve que raras vezes esteve tão absorvido como nos Diálogos Científicos de Joyce ${ }^{134}$ e o autor manteve-se resistente às críticas de seu pai em relação ao livro quando dizia que o livro sustentava uma pobreza de raciocínio sobre os primeiros princípios da Física que predominariam na primeira parte desta obra. Mill teria lido, também, tratados de Química ${ }^{135}$, especialmente do Doutor Thomson, anos antes de assistir a uma conferência ou presenciar um experimento ${ }^{136}$.

\footnotetext{
Sad is my fate! Said the heart-broken stranger,

The wild deer and wolf to a covert can flee;

But I have no refuge from famine and danger,

A home and a country remain not to me.

Never again, in the green sunny bowers,

Where my forefathers liv'd, shall I spend the sweet hours,

Or cover my harp with the wild-woven flowers,

And strike to the numbers of Erin o Bragh!

Erin my country! Though sad and forsaken,

In dreams I revisit thy sea-beaten shore; (...)"
}

\footnotetext{
${ }^{132}$ A maioria das histórias populares da Inglaterra, bem como da guerra americana traçam uma impressão a respeito da desolação do vale de Wyoming. Os viajantes descrevem a colônia inglesa como uma das mais felizes da existência humana, por sua hospitalidade e inocentes modos que os habitantes possuíam. A beleza do país e a fertilidade do solo também eram características do local. O paraíso terrestre é, entretanto, convertido em horror, quando um massacre de revolucionários americanos se dá pelas mãos de legalistas. Sobre este contexto, o poema é escrito.

${ }^{133}$ Mill, 1873, p. 53 (Edição Liberty Fund).

${ }^{134}$ Este tratado define os fluídos e suas partículas, pesos e pressões sobre fluídos, descreve experimentos sobre isso. Trata da hidroestática e o peso sobre a água pura. A pressão exercida sobre os fluidos e a pressão que os fluidos exercem. O movimento dos fluidos. O tratado também descreve a gravitação de corpos na água (porque alguns corpos afundam e outros flutuam), as invenções de Arquimedes entre outros assuntos.

${ }^{135} \mathrm{O}$ tratado de Química de Dr. Thomson se divide em três livros. O primeiro livro, trata de substâncias chamadas simples por ele, ou elementos que podem ser mantidos juntos, como oxigênio (que pode misturar-se a outro elemento) e metais que podem ser mantidos juntos a outros corpos. A segunda divisão do primeiro livro descreve elementos que não podem ser mantidos juntos como a luz e o calor. No livro
} 
Com a idade de doze anos Mill entrou em outro e mais avançado estágio de seu curso de instrução, no qual o principal objeto era com a ajuda e aplicação do pensamento a temas diversos, debruçar-se sobre os próprios pensamentos. Ele começou com a Lógica, na qual o autor se iniciou diretamente com Organon ${ }^{137}$, lendo-o até os Analíticos. Ao mesmo tempo em que foi introduzido ao Organon, seu pai o fez ler tratados latinos de lógica escolástica, alguns inteiros, outros em parte. É relato da Autobiografia que todos os dias em seus passeios, Mill fazia uma minuciosa descrição do que havia lido, respondendo às suas várias e profundas perguntas. Depois destes livros, Mill leu o Computatio sive Logica de Hobbes, um trabalho de mais elevado pensamento do que os escolásticos, na opinião do autor. Era um costume de seu pai, não importavam quais fossem os estudos que exigisse de Mill, o fazer compreender e sentir a utilidade deles. Isto the pareceu especialmente adequado no caso da lógica silogística, cuja utilidade havia sido contestada por muitos escritores de autoridade. Durante um passeio, através de perguntas, seu pai o fez pensar sobre o tema, pedindo-lhe que formasse idéias sobre o que constituía a utilidade da lógica silogística e quando percebeu que Mill era incapaz de formular explicações, decidiu fazê-lo entender o assunto mediante explicações. Essas explicações permaneceram como um núcleo sobre o qual se cristalizaram suas observações e reflexões. Assim, sua própria reflexão e experiência o levaram a dar o mesmo valor que seu pai dava à lógica escolástica. Portanto, Mill diz que, em sua educação, reflexões sobre a lógica o auxiliaram muito em sua capacidade de pensar. $\mathrm{O}$ autor ressalta que:

"[...] A primeira operação intelectual na qual consegui alguma destreza foi a de analisar um mau argumento, encontrando em que parte residia sua falácia. [...]” [Mill, 1873, p. 37].

segundo trata de elemento que estão combinados como óxido de carbono, por exemplo. O terceiro livro trata de um exame químico da natureza, da atmosfera, da água.

${ }^{136}$ Mill, 1873, p. 36

${ }^{137}$ Neste livro Aristóteles apresenta as leis do raciocínio. 
Portanto, formava-se a mente analítica de $\mathrm{Mill}^{138}$, a partir dos sólidos estudos de livros de lógica, ciência, química e matemática e também devido ao método rigoroso de educação ensinado por seu pai. Durante este período, o autor não deixou de ler autores gregos e latinos que Mill descrevia serem importantes não apenas pela linguagem, mas também pelos pensamentos. Estes incluíam muitas obras de oradores, conforme explicitado, especialmente de Demóstenes, cujos principais discursos leu várias vezes, escrevendo, como exercício, uma análise completa de alguns. Neste período, Mill também leu integralmente Juvenal ${ }^{139}$ e Quintiliano ${ }^{140}$. Este último, de acordo com Mill, devido a seu estilo obscuro e aos detalhes escolásticos que compõem grande parte de seu tratado, é um autor pouco lido e raras vezes adequadamente avaliado. Seu livro poderia ser considerado uma espécie de enciclopédia do pensamento antigo no campo da educação e da cultura. Foi nesta época, também, que Mill leu, pela primeira vez, alguns dos mais importantes diálogos de Platão, em particular Górgias, Protágoras e a República. De acordo com Mill, o método socrático do qual são compostos os diálogos de Platão constitui insuperável método para corrigir os erros que decorrem de uma mente abandonada a si mesma. A maneira como era formulada a indagação, por parte de Sócrates, assim descrita nos Diálogos de Platão, pela qual o homem que estabelece afirmações vagas é obrigado a expressar o que ele quer dizer em termos definidos ou a confessar que não sabe do que está falando ${ }^{141}$, todos estes recursos, de acordo com o autor, são fundamentais para ensinar a racionar de maneira exata. Essas conclusões, derivadas do conhecimento da lógica, especialmente antiga e medieval, apesar da idade que o autor tinha, passou a formar parte de sua mente. Desde então, sempre pensou que o epíteto platônico pertence mais àqueles que se esforçaram por praticar o modo de investigação usado por Platão do que àqueles que só se distinguem pela adoção de certas conclusões dogmáticas.

Outro livro que contribuiu amplamente para a educação de Mill foi o livro de seu pai a História da Índia, publicado em 1818. O número de novas idéias que ele recebeu deste livro, o impulso e estímulo, bem como o guia dado aos seus pensamentos

\footnotetext{
${ }^{138}$ Apesar da leitura de poetas, o que parece ter prevalecido até então foram suas leituras mais analíticas, salvo alguns momentos, conforme descrito, pelos relatos de Mill.

${ }_{139}^{139}$ Juvenal foi poeta grego.

${ }^{140}$ Foi um retórico romano, amplamente citado nas escolas medievais de retórica.

${ }^{141}$ Mill, 1873, p. 39.
} 
pela crítica e pesquisa a respeito da sociedade e civilização Hindu, no que concerne às instituições e atos do governo inglês, tornaram sua precoce familiaridade com essa obra algo muito útil para seu desenvolvimento posterior.

Em Economia Política, o autor leu um livro publicado por Ricardo, denominado On the Principles of Political Economy and Taxation. Outro importante autor de economia política era Adam Smith, sendo objetivo principal de seu pai, fazer Mill acreditar que as doutrinas de Smith eram mais superficiais do que as de Ricardo e descobrir o que havia de falacioso nos argumentos de Smith ou errôneo em suas conclusões $^{142}$.

Mill ressalta que seu pai jamais permitiu que o seu aprendizado fosse degenerado em um mero exercício de memória, esforçando-se para que a compreensão acompanhasse tudo aquilo que ele fosse aprendendo. O autor ainda ressalta que a solução dos problemas que ele poderia resolver pensando sozinho nunca the foi dada de maneira antecipada, antes dele haver esgotado todos os meios de poder descobri-la por si mesmo.

É possível afirmar, a partir do até aqui exposto, que Mill teve educação intelectual prematura sólida, entretanto, o autor relata que o oposto ocorria quando um trabalho exigia destreza manual, como na passagem abaixo citada. De acordo com Mill:

"Minha mente - assim como minhas mãos - funcionava muito mal quando era aplicada, ou deveria ser aplicada, aos detalhes práticos, que constituem o principal interesse da vida da maioria dos homens e que, assim, são também as coisas em que se manifesta a capacidade mental deles, qualquer que esta seja.” [Mill, 1873, p. 50].

Mill relata que cresceu com uma grande incapacidade para tratar de assuntos cotidianos. Descreve que demorou mais tempo do que as outras crianças para conseguir colocar suas próprias roupas. Não sabe quantos anos passaram até que pudesse fazer um nó. Sua articulação foi por muito tempo imperfeita; só conseguiu pronunciar a letra $r$ quando tinha dezesseis anos de idade, descreve que nunca conseguiu, e mesmo no

\footnotetext{
${ }^{142}$ Não é tema desta tese tentar entender porque o pai de Mill acreditava que o pensamento Ricardiano era superior ao de Smith, nem o autor explica tal afirmação na Autobiografia. O importante é entender que Mill estava sendo exposto a argumentos econômicos de Ricardo e Smith (ambos desenvolveram a teoria do valor trabalho).
} 
momento em que escreveu a Autobiografia não pôde fazer algo que exigisse habilidade manual e nunca exercitou o entendimento em questões práticas ${ }^{143}$.

Ressaltada esta dificuldade que Mill relatava apresentar em relação a trabalhos que não se referiam a tarefas intelectuais, pode-se dizer que as leituras expostas até este momento do texto (com idade de doze anos) foram as principais em sua educação, seguindo o relato do autor em sua Autobiografia.

Entretanto, antes de continuar a descrever a educação de Mill, conforme transcorre sua idade, é interessante destacar que um ponto importante de seu aprendizado estava baseado no fato de que sua educação foi totalmente esvaziada de conteúdo religioso. Mill sustentava que a respeito da origem das coisas nada poderia ser conhecido. Esta era a única correta afirmação, pois considerava o ateísmo dogmático, um absurdo de igual medida ${ }^{144}$. Esta questão particular é importante, pois mostra que a rejeição de seu pai de tudo que é chamado de crença religiosa não era, como muitos podem supor, uma questão de lógica e evidência, era antes uma questão moral, mais do que uma questão intelectual. Seu pai considerava impossível acreditar em um mundo repleto de maldade como sendo a obra de autor que combinava infinito poder com perfeita bondade e retidão. Seu intelecto rejeitava as lendas pelas quais os homens tentavam tornar-se cegos a esta contradição aberta $^{145}$.

As convicções do pai de Mill, James Stuart Mill, eram formadas totalmente à parte de religião. Conforme mencionado anteriormente, a leitura precoce de autores que retratavam o método socrático produziu em Mill um profundo respeito pelo caráter de Sócrates que, conforme já descrito, deixou em sua mente um modelo de excelência ideal de pensamento.

Como é possível depreender a partir desta rígida disciplina intelectual, James Stuart Mill, o pai de John Mill, julgava os prazeres derivados de fontes intelectuais superiores aos demais prazeres. Tal idéia constituiu importante elemento para formação dos conceitos morais do próprio John Mill, representando fundamental noção para a

\footnotetext{
${ }^{143}$ Nota 13 Mill, 1873 , p. 51.

${ }^{144}$ Não obstante Mill realizar esta afirmação na Autobiografia, a não necessidade da existência de Deus está plenamente de acordo com seu sistema, uma vez que para a formulação de leis científicas, ao menos em ciências sociais, necessita-se de leis empíricas, mais leis etológicas, mais leis da mente, em última instância o conhecimento do mundo social tem um componente psicológico e não necessita da existência de nenhuma Divindade para ser assegurado.

${ }^{145}$ Mill, 1873, p. 143 (Edição Liberty Fund).
} 
formação de seu novo conceito de indivíduo relativamente ao de Bentham, pois as faculdades mais elevadas que se satisfazem com prazeres de qualidade mais elevada serão um novo componente da natureza humana do conceito de indivíduo teórico de Mill, como se verá adiante. Sobre seu pai considerar os gozos intelectuais como superiores a todos os outros, segue passagem da Autobiografia de Mill comprovando tal afirmação:

"Dizia por vezes que se a vida fosse o que ela poderia ser, guiada pelo bom governo e a boa educação, valeria a pena vivê-la, mas, nem diante de tal possibilidade, falava com entusiasmo. Nunca deixou de julgar os gozos intelectuais superiores a todos os outros inclusive em seu valor como prazeres [...]" [Mill, 1873, p.51].

Outra importante influência de John Stuart Mill foi Condillac, através do Tratado das Sensações ${ }^{146}$, bem como os volumes de lógica e a metafísica que formavam seu Cours d'etudes. Durante o inverno de 1821-1822, John Austin, a quem James Mill havia conhecido quando John Stuart Mill estava na França, permitiu que John Mill estudasse Direito Romano em sua companhia. Apesar do aborrecimento de James Mill com o direito inglês, considerou que esta seria a menos inadequada profissão para Mill. As leituras com Austin eram uma valiosa preparação aos estudos jurídicos e uma importante parte da educação geral de Mill. Com Austin, Mill leu direito romano, parte das Pandectas ${ }^{147}$, aos quais acrescentou uma parte considerável de Blackstone ${ }^{148}$. Foi no começo desses estudos, que James Mill presenteou Mill com as principais considerações de Bentham, tal como eram interpretadas para o continente, por Dumont, em seu Traité de législation. A leitura de Bentham parece configurar um outro ponto de inflexão na formação do pensamento de Mill, conforme narrado por ele: A leitura deste livro marcou

\footnotetext{
${ }^{146}$ Condillac é considerado um empirista radical, faz uma crítica radical à teoria racionalista das idéias inatas, acolhendo amplamente a tese de que todas as nossas idéias se originam a partir da experiência. Essa tese filosófica tinha sua exemplificação mais acabada naquilo que foi a maior glória científica de seu tempo, a saber: a síntese newtoniana. A obra de Newton fornecia como o conhecimento se constiu e seus limites, a partir da experiência. Newton reduziu o mundo físico a um único, ao princípio da gravitação. [Condillac, 1754, p. 8]

${ }^{147}$ Compilação de fragmentos jurídicos clássicos.

${ }^{148}$ Mill, 1873, p. 72. Blackstone foi jurista da época de Bentham com o qual Bentham não simpatizava, pelo fato de acusar Blackstone de não possuir um princípio de justiça positivo para guiar seus pensamentos jurídicos.
} 
uma época de minha vida e foi um ponto decisivo em minha história mental [Mill, 1873, p. 72].

Mill descreve que, em certo sentido, sua educação prévia já havia sido um curso de benthamismo. Relata na Autobiografia que aprendeu sempre a aplicar o critério da "maior felicidade", de Bentham, e diz que estava até mesmo familiarizado com uma discussão abstrata deste princípio, escrita por seu pai, segundo o modelo platônico.

O que mais chamou a atenção de Mill foi o capítulo ${ }^{149}$ em que Bentham criticava os modos habituais de pensar as questões da moral e da legislação, em que aparecem certas expressões como "lei da natureza", "razão certa", "sentido moral", "retidão natural" e outras semelhantes, caracterizando-os como um dogmatismo disfarçado que tenta apenas impor determinados sentimentos aos demais, ocultando-os sob expressões que não fornecem razões para os sentimentos, mas tornam os sentimentos em razão de si mesmos ${ }^{150}$. O princípio de Bentham punha um fim a tudo isso, os moralistas anteriores haviam sido superados, e para o autor, começava uma nova era de pensamento. Esta impressão foi fortalecida pela maneira com que Bentham aplicava o princípio da felicidade à moralidade das ações. E algo que muito impressionou Mill, foi também a classificação dos delitos no utilitarismo de Bentham que é muito mais clara, concisa e imponente na redação de Dumont, do que na obra de Bentham, de acordo com Mill. A lógica e a dialética de Platão ocuparam parte considerável de sua preparação anterior. Este gosto foi fortalecido e iluminado pelo estudo da Botânica, uma vez que o método natural de classificação científica podia ser aplicado ao vasto e complexo assunto relativo aos atos suscetíveis de punição. Os atos concernentes à punição seriam guiados pelo princípio ético das conseqüências prazerosas e dolorosas. Mill descreve em seu livro Autobiografia que se sentiu elevado a uma distância em que poderia enxergar resultados intelectuais insuspeitados até então. $\mathrm{O}$ autor ressalta que é certo que não era alheio às visões gerais de Bentham acerca da construção de um corpo de leis, pois podia entender de que maneira o princípio da utilidade poderia ser aplicado à legislação ${ }^{151}$. O autor

\footnotetext{
${ }^{149}$ Capítulo III da obra editada e traduzida para o francês por Dumont (1802). Na versão inglesa, $A n$ Introduction to the Principles of Morals and Legislation, capítulo II e XVII.

${ }^{150}$ Mill, 1873, p. 73.

${ }^{151}$ Faz sentido Mill dizer que o tema de Bentham era a legislação, pois a moral fica bastante reduzida no utilitarismo de Bentham, uma vez que o indivíduo derivado do utilitarismo de Bentham, auto-interessado, reavalia as regras da moral, a cada ação.
} 
descreve que a cada página parecia se aclarar uma concepção a respeito do que deveriam ser as opiniões e as instituições humanas, de como estas poderiam chegar a ser o que deveriam ser e de como estavam distantes disto ${ }^{152}$. Quando Mill terminou o último volume do Traité, de acordo com sua descrição na Autobiografia, havia se tornado um ser diferente ${ }^{153}$. O princípio de utilidade, entendido como Bentham o entendia e aplicado como Bentham o havia aplicado ao longo dos três volumes do Traité de Législation, unia todos os elementos fragmentados dos conhecimentos e crenças do autor, conforme descrito por Mill [1873, p. 74]:

"Dava unidade às minhas concepções das coisas. Eu passava a ter assim opiniões, um credo, uma doutrina, uma filosofia e, em um dos melhores sentidos da palavra, uma religião cuja propagação e difusão podia constituir a principal finalidade de uma vida. Tinha diante de mim uma grande concepção das mudanças que poderiam ser efetuadas na condição da humanidade mediante aquela doutrina."

O Traité de Législation condensava o que Mill descrevia ser a mais impressionante imagem do que poderia vir a ser a vida humana caso fosse regida pelas opiniões e leis recomendadas no livro. As doutrinas de Bentham haviam produzido em Mill algo que aumentava e muito sua impressão em relação ao poder intelectual de Bentham. Sendo que, conforme o autor descreve: [Mill, 1873, p. 75] “[...] E as perspectivas de aperfeiçoamento que Bentham abria eram suficientemente amplas $e$ brilhantes para iluminar a minha vida e dar uma forma definida às minhas aspirações”. Depois disso, o autor relata que passou a ler esporadicamente as mais importantes das outras obras de Bentham, seja segundo ele mesmo escreveu, seja segundo Dumont as editou. Estas eram suas leituras privadas, entretanto, sob a direção de seu pai, começou a estudar os ramos superiores da psicologia analítica. Conforme relatado na Autobiografia leu o Ensaio acerca do Entendimento ${ }^{154}$ de Locke e escreveu um comentário que consistia em um detalhado resumo de cada capítulo com as observações que o ocorriam.

\footnotetext{
${ }^{152}$ Mill, 1873, p. 74.

${ }^{153}$ Mill, 1873, p. 74.

${ }^{154}$ Assim como o Tratado das Sensações de Condillac o Ensaio de Locke refuta o inatismo. A primeira afirmação do Ensaio de Locke é que não há princípios inatos na mente.
} 
Mill descreve ter seguido o mesmo procedimento com De L'esprit de Helvetius ${ }^{155}$. Depois de Helvetius, seu pai o fez estudar o que ele considerava a obra mestra na filosofia da mente, as Observações sobre o homem ${ }^{156}$, de Hartley. Este livro embora não o tenha impactado, assim como o Traité de législation, causou em Mill uma impressão similar no que diz respeito ao tema de que tratava. O autor argumenta, que apesar de incompleta em muitos pontos, a explicação que Hartley propunha para os mais complexos fenômenos mentais, servia-se, para isso, da lei de associação ${ }^{157}$, apresentavase a Mill como uma verdadeira análise e o fez perceber, a insuficiência das generalizações meramente verbais de Condillac. Foi nesta mesma época que seu pai começou a escrever sua Análise da Mente, que, pela percepção do autor, o levava a uma dimensão mais extensa e profunda de explicação do pensamento quando comparado ao modo pelo qual Hartley havia elucidado os fenômenos mentais. Os outros principais escritores britânicos de filosofia da mente que Mill leu, segundo descreve, foram, sobretudo, Berkeley, Hume ${ }^{158}$, Reid ${ }^{159}$, Dugald Stewart ${ }^{160}$ e Brown ${ }^{161}$.

Outras obras lidas durante este mesmo ano de 1822 e que contribuíram de maneira significativa para a formação de Mill foram um livro escrito a partir de alguns manuscritos de Bentham e publicado sob o pseudônimo de Philip Beuchamp ${ }^{162}$ intitulado Análise da influência da religião natural na felicidade temporal da humanidade. Este livro constituía-se, não da verdade, mas da utilidade da crença religiosa, considerada esta em um sentido amplo e com independência das peculiaridades de tal ou qual revelação

\footnotetext{
${ }^{155}$ Também da corrente empirista Helvetius, nesta obra, prova que a sensibilidade é a principal causa produtora das idéias.

${ }^{156}$ Do prefácio de Hartley, 1834, é possível perceber o quanto este autor influenciou Mill: “About eighteen years ago I was informed, that Ver. Mr. Gay, then living, asserted the possibility of deducing all our intellectual pleasures and pains from association. [...] From inquiring into the power of association, I was led to examine both its consequences, in respect of morality and religion, and its physical cause.

${ }^{157}$ Sobre as leis de associação cito Hume em Investigações Sobre o Entendimento Humano, Seção III-Da Associação de Idéias, 19: "Quanto a mim, creio existirem apenas três princípios de conexão entre as idéias, a saber: a semelhança, a contiguidade de tempo ou lugar, e a causa e efeito.

${ }^{158}$ Vide leis de associação acima elencadas.

${ }^{159}$ Reid, 1861, também escreve a respeito de como a mente opera segundo fica explícito no exemplo a seguir: "The second and most common way, in which men form their opinions concerning the mind and its operations, we may call the way of analogy".

${ }^{160}$ Dugald Stewart afirma que todos os primeiros princípios das ciências pertencem à mente humana. John Mill será amplamente influenciado por Dugald Stewart, pois como está explícito no quarto parágrafo de seu texto On the Definition of Political Economy, Mill reafirma a afirmação de Stewart.

${ }^{161}$ Investigações sobre a relação de causa e efeito (1818), de Thomas Brown.

${ }^{162} \mathrm{O}$ autor foi George Grote.
} 
específica. De todas as partes que se referem ao tema da religião, Mill considerava aquela a mais importante de seu tempo, pois se a verdadeira crença em qualquer doutrina religiosa era débil e precária, aceitava-se, entretanto, quase universalmente, sua necessidade para lograr os propósitos da natureza moral e social, e era disto que este autor trata no livro Análise da influência da religião natural na felicidade temporal da humanidade.

Estes foram os principais autores que tiveram um peso considerável na educação de John Stuart Mil, sendo que, a partir de então, o autor passou a cultivar as próprias idéias, escrevendo. É importante ressaltar que de todas essas influências algumas se configuraram como pontos de inflexão em sua educação, no que concerne, especialmente, à formação de suas idéias morais. Até aqui pode-se verificar dois pontos de inflexão bastante marcados, a saber: a) quando o autor leu a Retórica de Aristóteles ${ }^{163}$ e principalmente b) quando o autor leu o Traité de Legislatión de Bentham.

Especialmente após ler Bentham, logo após o verão de 1821, Mill descreve que tinha um objetivo em sua vida; ser um reformador do mundo. A concepção de sua própria felicidade estava identificada com este objetivo. A melhora do mundo era a idéia na qual Mill engajou-se juntamente com outros lutando para promovê-la. Tal idéia parecia ser uma noção suficientemente interessante para animar sua existência, assim como Mill descreve em sua Autobiografia:

\footnotetext{
"E assim eu me parabenizava pela certeza de haver encontrado um modo feliz de viver, ao situar minha felicidade em algo durável e distante, em algo que sempre admitia a realização de novos progressos, mas que jamais poderia ser esgotado pela consumação definitiva”. [Mill, 1873, p. 124]
}

Entretanto, o tempo passou e Mill acordou deste momento como de um sonho. Mill relata que foi no outono de 1826. O autor descreve que se encontrava em um estado de indiferença, ao qual todos estão, eventualmente, sujeitos. Mill estava insensível aos estímulos da felicidade, um estado de ânimo em que nada pode tornar-se agradável, mesmo aquilo que no passado constituía objeto de prazer. Neste estado de espírito Mill

${ }^{163}$ Mill, 1873, p.32. 
indagou-se: "suponha que todas as suas metas na vida fossem realizadas, que todas as transformações perseguidas nas instituições e opiniões pudessem ser efetuadas neste instante mesmo: seria isto motivo de grande alegria e felicidade para ti?" consciência, sem poder reprimir-se, respondeu: “Não!”. Mill relata, então haver se abatido: todo o conhecimento e certezas sólidas sobre as quais ele havia erigido sua própria vida encontravam-se em ruínas. Sua felicidade, seu prazer até então, consistia na constante procura das transformações das instituições, sendo que tal finalidade já não era mais objeto de seu desejo. A falta de vontade em atingir esses objetos, postos por seu desejo antes de sua crise mental, o levava a não ter nenhuma motivação em buscar meios para realizar tais finalidades, como a transformação de instituições vigentes. $\mathrm{O}$ autor descreve que: "Parecia, então, que não restava mais nada para o quê viver" [Mill, 1873, p. 124].

De início Mill pensou que a tristeza apagar-se-ia sozinha, entretanto não foi assim que os fatos sucederam-se. Uma noite de sono, soberano remédio para os pequenos desgostos da vida, não produziu efeito neste caso [Mill, 1873, p.124]. O autor trazia a tristeza consigo, quando estava na companhia dos outros e quando se ocupava em qualquer trabalho. Dificilmente algo tinha o poder de fazer esquecer esta nuvem cinzenta (um arquétipo para descrever o que sentia), ainda que fosse por minutos...

Por alguns meses a nuvem pareceu tornar-se cada vez mais pesada, para o autor. Os versos do poema de Coleridge intitulado "Abatimento" ["Dejection”] - até então desconhecidos para Mill, naquele momento, descrevem, com precisão, o seu caso [Mill, 1873, p. 124]:

"A grief without a pang, void, dark and drear,

A drowsy, stifled, unimpassioned grief,

Which finds no natural outlet or relief

In word, or sigh, or tear." 165

164Mill, 1873, p. 124.

165 Coleridge, "Work without Hope," in Poetical Works, 3 vols. (London: Pickering,

1828), Vol. II, p. 81. "Uma grande tristeza sem uma emoção aguda, inaceitável,escura, sem interesse, Um impassível, irrespirável, desapaixonado sentimento. Que não acha uma forma de ser expresso ou de ser aliviado Em palavra, ou respiro, ou lágrima. 
De nada adiantou Mill buscar ajuda em suas obras prediletas, das obras históricas, de personagens que serviam de exemplo de força a ele. $\mathrm{O}$ autor relata que após esse abatimento, lia esses autores e obras sem nenhum tipo de excitação ou emoção. A impressão de Mill era a de que não possuía mais amor pelo gênero humano, nem pelas metas de melhoria das instituições que havia se proposto. Além disso, sentia que não possuía ninguém que amasse o suficiente para partilhar o que se passava com ele. Sua conclusão era a de que: se amasse alguém o suficiente para chegar a confidenciar-lhe suas aflições, talvez não haveria chegado à situação em que estava [Mill, 1873, p. 25]. Sentia, além disso, que seu pesar não era nem interessante nem respeitável. Os dizeres de Macbeth ao médico lhe ocorriam repetidas vezes ${ }^{166}$. Contudo, o autor tinha a impressão de que não havia ninguém de quem esperar socorro no que dizia respeito a sua dor. O pai de Mill poderia, hipoteticamente, constituir uma saída ou um alento para ajudar no momento emocional, difícil, pelo qual Mill passava e poderia parecer até mesmo natural que Mill recorresse a ele, dado a proximidade de ambos, entretanto, Mill pensava ser esta a última pessoa a quem deveria recorrer, pois o autor acreditava que seu pai não conhecia o estado mental de que ele padecia. Mill havia sido educado por seu pai desde a infância sem que seu pai contasse com o fato de que este autor pudesse vir a ter uma crise mental, sendo que o autor não gostaria de fazer seu pai acreditar que seus esforços haviam fracassado, pois estava certo de que James Mill não poderia fornecer a cura para sua dor. Mill também não identificava nenhum amigo que pudesse compreender seu estado. Entretanto, ele compreendia perfeitamente seu estado e quanto mais se demorava nele, mais desesperado ficava ${ }^{167}$.

A maneira como foram conduzidos os estudos de Mill fizeram com que o autor acreditasse que os sentimentos e qualidades morais e mentais bons ou maus eram derivados da associação ${ }^{168}$; devido ao resultado da educação e de experiências prazerosa o indivíduo passa a amar ou a odiar determinadas coisas, como resultado da associação de idéias que provém da experiência (pois de acordo com a primeira lei da mente, constituinte de nossa natureza humana: toda impressão mental tem sua idéia). Como

\footnotetext{
${ }^{166}$ Canst thou troubles of the brain to a mind diseased, /Pluck from the memory a rooted sorrow, /Raze out the written troubles of the brain,/ And with some sweet oblivious antidote/ Cleanse the stuff'd bosom of that perilous stuff/Which weights upon the heart? (Macbeth, V, III), Shakespeare, 1607.

${ }^{167}$ Mill, 1873 , p. 126.

${ }^{168}$ Mill, 1873, p. 126
} 
decorrência deste pensamento de Mill, o papel da formação de qualidades morais e mentais era ocasionar os melhores tipos de associações possíveis, ou seja, a partir da experiência da educação moral ou mental, o objetivo seria associar a sensação de prazer a tais experiências. Esta doutrina aparentava ser a correta, mas, em meio a sua crise mental, o autor considerava que seus mestres não se ocupavam o suficiente de manter esta associação entre qualidades morais e mentais e prazer. As associações das quais seus mestres ocuparam-se eram baseadas, sobretudo, na questão da recompensa e castigo, meios pelos quais as associações de prazeres e dores, principalmente, de dores eram criados em relação à formação moral do agente. Contudo, Mill ressalta que tais associações eram artificiais, pois eram estimuladas depois de ensinado o método habitual da análise. Portanto, para Mill o fortalecimento das associações da sensação de prazer com idéias formadas por qualidades mentais e morais devia ocorrer antes que o hábito da análise tomasse conta da mente. Uma vez que Mill percebia que o hábito de análise tem uma tendência a corroer os sentimentos quando não se cultiva outro hábito mental ${ }^{169}$.

De acordo com Mill:

[...] pois devemos à análise o conhecimento mais seguro que possuímos a respeito das seqüências permanentes da natureza, das conexões reais entre as coisas, que independem de nossa vontade e de nossos sentimentos, e das leis naturais em virtude das quais uma coisa é, em muitos casos, de fato inseparável de outra [...]. [MILL, 1873,p.127].

Assim, os hábitos analíticos podem inclusive fortalecer as associações entre causas e efeitos entre meios e fins, mas tendem a debilitar todos aqueles que são para empregar linguagem comum, mera questão de sentimento ${ }^{170}$. De acordo com Mill, os hábitos analíticos eram fundamentais para cultivar a clarividência, mas funcionariam como que um verme que destruiria pela raiz todas as paixões e virtudes, minando de maneira quase que definitiva os prazeres resultantes da associação com outros hábitos quando não realizados anteriormente à análise. Neste ponto poder-se-ia introduzir uma crítica ao homem calculador de Bentham, um homem que busca maximizar prazer e

${ }^{169}$ Ibid, p. 127.

${ }^{170}$ Mill, 1873, p. 127. 
minimizar dor a todo instante, esta, sem sombra de dúvida, poderia ser considerada uma mente analítica por Mill, onde aqui sobraria espaço para a associação do prazer com o cultivo de qualidades morais, por exemplo? uma pergunta como esta pretende-se responder ao longo deste trabalho.

$\mathrm{O}$ autor ressalta que o cultivo de uma mente analítica, antes de haver instalado-se o hábito de associação do prazer com qualidades morais e mentais nele, constituía um forte motivo que o havia levado ao presente estado de crise mental, forte tristeza. Tanto Mill quanto muitos autores que admirava estavam convencidos que simpatizar com demais humanos era uma das maiores fontes de felicidade, entretanto, saber e reconhecer esta verdade não resultava este sentimento em Mill. Segundo o autor, o hábito precoce da análise havia penetrado seu espírito antes que fosse exposto à associação de prazer com qualidades mentais e morais, talvez definitivamente, conforme descreve:

"[...]Estava, pois, - como eu dizia a mim mesmo - encalhado no começo de minha viagem: equipado com um bom barco e um bom leme, mas sem vela, sem um verdadeiro desejo de alcançar os fins para os quais eu havia sido cuidadosamente preparado para alcançar. Não me comprazia nem na virtude, nem no bem geral, nem tampouco em nenhuma outra coisa[...]"[MILL,1873, p. 128.]

Além disso, outras fontes que poderiam servir de estímulo para que Mill alcançasse seus fins, como a vaidade, não serviam a ele, pois ele havia alcançado algum reconhecimento em uma idade bastante precoce.

Durante sua crise nada aprazia John Stuart Mill. O autor relata na Autobiografia que não parecia haver nada na natureza capaz de modificar seu caráter irremediavelmente analítico e convertê-lo em alguém capaz de formar novas associações prazerosas com qualidades morais e mentais, estes eram os pensamentos que derivavam do pesado abatimento de seu dito melancólico inverno de $1826-1827^{171}$. O autor descreve que só pôde continuar realizando suas tarefas cotidianas devido à força do hábito (um dos componentes da natureza humana).

${ }^{171}$ Mill, 1873, p. 128. 
O único autor que era capaz de descrever seus sentimentos, naquele momento, era Coleridge ${ }^{172}$, este autor vinha com freqüência a seu pensamento ${ }^{173}$, em um período posterior, porém ainda quando se encontrava doente:

Work without hope draws nectar in a sieve, And hope without an object cannot live ${ }^{174}$.

O autor não pensava que seu caso fosse único, porém as peculiaridades de sua educação o faziam pensar que seu sofrimento não seria passageiro como talvez o fosse o sofrimento de outra pessoa com um tipo de educação menos rara. Portanto, muitas vezes pensava se passaria a vida toda naquele estado, mas a resposta era sofrida, dolorida; que não agüentaria passar mais de um ano naquela situação. Contudo, quando não havia passado metade de um ano, o autor sentiu alguma emoção, isto ocorreu quando o autor estava lendo as Memórias de Marmotel $^{175}$; a passagem que o comoveu relatava a morte do pai de um jovem. Esse jovem, então, passaria a constituir tudo para a família. A partir da leitura dessa passagem e vívida representação da cena, no pensamento de Mill, o autor comoveu-se e expressou emoção, novamente, através do choro. Deste momento em diante, o autor descreve que seu fardo se tornou mais leve ${ }^{176}$. A expressão de emoção de Mill através do choro parece ter sido de enorme importância, porque o autor relata que já não parecia mais que seus sentimentos estavam mortos que ainda possuía o material com o qual seria possível formar caracteres valiosos e a partir deles auferir a felicidade. Com o conforto da descoberta do fato de que não mais estava preso a uma desgraça irremediável da qual não mais poderia sair, a saber: sua apatia em relação a todos os fins aos quais havia se proposto, sentiu, então, que poderia encontrar prazer suficiente em diversas fontes como: na luz do sol, na apreciação do céu, na leitura dos livros, nas conversas e nos assuntos públicos. Em suas palavras:

\footnotetext{
${ }^{172}$ Foi poeta e filósofo inglês, juntamente com Wordsworth, foi fundador do movimento romântico na Inglaterra.

${ }^{173}$ Ibid, p. 129.

${ }^{174}$ Mill, 1873, p. 129. Trabalhar sem esperança é lançar o néctar em uma peneira.

${ }^{175}$ Escritor francês do século XVIII. E a esperança sem objeto não pode viver.

${ }^{176}$ Mill, 1873, p. 129.
} 
"Eu voltava a sentir emoção, embora moderada, ao trabalhar por minhas idéias e pelo bem público. Assim, a nuvem foi se desvanecendo pouco a pouco e de novo pude desfrutar da vida. Apesar de sofrer várias recaídas, algumas das quais duraram muitos meses, nunca voltei a ser tão infeliz como havia sido”. [Mill, 1873, p. 130]

As experiências desse período produziram dois efeitos marcantes nas opiniões e no caráter de Mill. Afirma-se isto neste trabalho, o próprio autor afirma isto em sua Autobiografia ${ }^{177}$ e Donner ${ }^{178}$ afirma isto em seu livro. É certo que jamais foi abalada a convicção de Mill de que a felicidade é o critério de todas as regras de conduta e o fim que se persegue na vida, ou seja, Mill continuava sendo um utilitarista, mas de tipo diferente de Bentham, pois após Mill ter passado por esta crise mental, entre outros pensamentos, o autor considerava que este fim só poderia ser alcançado não fazendo dele o objetivo imediato. Ou seja, Mill pensava que o prazer sem qualquer qualificação já não fazia mais sentido de ser perseguido. Nas palavras do autor ${ }^{179}$ :

"Só são felizes (eu pensava) os que têm a mente fixada em algum objeto que não seja a sua própria felicidade: na felicidade de outros, na melhora da humanidade, ou, inclusive, em alguma arte ou projeto que não se busque como um meio, mas como uma meta em si mesma ideal. Assim, apontando para outra coisa, encontra-se casualmente a felicidade”. [Mill, 1873, p. 130].

Seria possível, segundo a nova teoria utilitarista de Mill $^{180}$, obter as satisfações da vida, sem fazer delas o único objetivo. Em outras palavras, apontando para outro objetivo tais satisfações ou benefícios seriam conquistados. Assim não a felicidade, mas algum outro fim externo a ela, como algum propósito da vida, que sem dúvida (é afirmação desse trabalho) tem seu fundamento na busca da felicidade ou prazer ${ }^{181}$, mas

\footnotetext{
${ }^{177}$ Mill, 1873, p. 130.

${ }^{178}$ Ver Donner W. 1991, Introdução.

${ }^{179}$ Mais adiante ficará claro que será possível perseguir a felicidade sem pensar nela porque o indivíduo teórico de Mill apresentará um novo componente em sua natureza denominado hábito.

${ }^{180}$ O próprio Mill ressalta que teria, após sua crise mental, uma nova teoria, embora continuasse sendo um utilitarista.

${ }^{181}$ Mill 1873, p. 131.
} 
uma vez provado seu mérito a partir da associação com o prazer, passa a ser uma ação habitual $^{182}$.

\begin{abstract}
"Faze com que tuas reflexões, teu escrutínio, tua introspecção se esgotem nisso. E se tiveres a fortuna de vêlos rodeados por outras circunstâncias favoráveis, inalarás felicidade com o ar que respiras, sem deter-se a pensar nela, sem deixar que ocupe tua imaginação e sem afugentá-la com interrogações fatais. Essa teoria se converteu no fundamento de minha filosofia de vida”. [Mill, 1873 p. 131].
\end{abstract}

Mill havia extraído outra importante opinião após sua crise mental que decorria do fato de que tanto as capacidades ativas (de agir e realizar tarefas) e passivas (como de sentir) deveriam ter igual atenção na educação de uma pessoa. Mill não renegou a cultura intelectual nem por um instante, nem tão pouco menosprezou a importância da prática do poder de análise como uma condição essencial do avanço social e individual. Entretanto ${ }^{183}$, passou a considerar como de fundamental importância o concomitante cultivo das sensibilidades passivas, ou o estímulo da associação de prazer com qualidades morais (como de simpatia pelos outros).

"A manutenção de um equilíbrio entre as faculdades pareciame agora de primeira importância. $O$ cultivo dos sentimentos se converteu em um dos pontos primordiais de meu credo ético e filosófico”. [Mill, 1873, p. 131]

Após sua crise mental o autor passou a entender e mesmo sentir qual era o sentido de tudo aquilo que havia lido e ouvido dizer sobre poesia e arte para a formação da cultura humana ${ }^{184}$. Na Autobiografia o autor ressalta que a única arte que lhe chamou a atenção, desde criança, foi a música, e continuava achando que era a mais importante das artes para causar entusiasmo e excitar os sentimentos de ordem superior já existentes

\footnotetext{
${ }^{182}$ É importante notar que o hábito constituirá característica fundamental da formação dessa nova natureza humana do indivíduo teórico de Mill.

${ }^{183}$ Já ressaltei que Mill define os sentimentos como fruto de estados mentais, então torna-se difícil estabelecer esta linha divisória de onde finaliza a razão e começam os sentimentos, tudo que se sabe é que ambos são provocados por estados da mente, pois os estados da mente consistem em pensamentos, emoções, volições e sensações [Mill, 1843, Sistema de Lógica, Livro VI, Cap IV. P. 53].

${ }^{184}$ Mill, 1873, p. 132.
} 
nos seres humanos. Mill relata ${ }^{185}$ que havia experimentado os prazeres da música, assim como outros prazeres que não mais conseguira obter durante o período de crise que o abatera. Quando o autor passou a recuperar-se, a partir da leitura de Memórias de Marmotel, Mill ressalta que a música tornou-se um dos seus prazeres, especialmente no momento em que conheceu a ópera Oberon de Weber; as belas melodias da ópera, segundo retrata ${ }^{186}$, fizeram muito bem a ele, retomando sua sensibilidade. Contudo, o bem causado pela redescoberta da música, deste prazer de qualidade superior que havia descoberto anteriormente à sua crise mental, esquecido durante este período de sofrimento e redescoberto novamente, causava angústia à Mill, pois este autor pensava que as combinações musicais poderiam esgotar-se. Em suas palavras:

"A oitava consiste apenas em cinco tons e dois semitons, que só podem ser combinados em um número limitado de formas, das quais poucas são belas. A maioria dessas, pensava eu, já deviam estar descobertas, e não poderia haver assim uma longa sucessão de Mozarts e Webers capazes de encontrar, como estes fizeram, filóes inteiramente novos e ainda mais ricos de beleza musical”. [Mill, 1873, p. 132].

De acordo com o autor, esta preocupação provinha da melhor parte de seu caráter, pois a questão principal era saber se os prazeres da vida continuariam a ser prazeres no momento em que as instituições fossem reformadas e ideais até então inatingíveis fossem atingidos. Se não encontrasse uma saída para esta indagação sua melancolia continuaria. Caso percebesse uma saída para esta questão associaria o mundo, então, com prazer, novamente, contentando-se com uma justa participação no quinhão geral $^{187}$.

Assume-se, portanto, a conclusão de que Mill estava criticando a maneira analítica de pensar quando descolada de associações que devem estar vinculadas às idéias de prazer por certas coisas antes que uma mente analítica fosse criada. De acordo com Mill, um indivíduo passa a amar certas coisas e odiar outras, a se comprazer com ações e contemplações de um tipo e sofrer com outras de outro tipo diversos, a associar objetos e

\footnotetext{
${ }^{185}$ Mill, 1873, p. 132.

${ }^{186}$ Mill, 1873, p. 132.

${ }^{187}$ Mill, 1873, p. 133.
} 
ações às paixões e depois aprende as operações analíticas. A maneira sozinha de raciocinar ou de educar uma pessoa no método da análise, antes daquelas associações poderia suprimir as emoções. Levando em consideração que as novas emoções que Mill começou a sentir após sua crise mental fizeram com que ele revisasse o modelo de homem de Bentham, torna-se relevante levar em consideração as principais influências após sua crise mental para entender como continuará conformando-se o novo modelo de homem do autor, relativamente ao de Bentham. Tais autores citados a seguir também parecem terem tornado-se pontos de inflexão, para Mill.

Wordsworth $^{188}$ foi um importante poeta lido por Mill naquele momento de sua vida (no outono de 1828). Na Autobiografia ${ }^{189}$, Mill descreve que lançou mão da coletânea de poemas de Wordsworth, sem esperar que este autor pudesse efetuar grandes mudanças em seu estado de espírito, entretanto, acabou por se surpreender positivamente. Mill não esperava grandes resultados da leitura de Wordsworth, pois já havia buscado alento na leitura de Byron, quando o que havia conseguido da leitura deste último fora uma piora de seu estado de espírito, decorrente da semelhante dor, que, provavelmente, Byron estava acometido. O lamento de Byron parecia ser o de um homem que havia exaurido todos os prazeres, que acreditava que a vida era algo sem interesse, precisamente aquilo que Mill havia descoberto, em seu período de crise. Seus personagens Harold e Manfred carregavam o mesmo peso que Mill e seu estado de ânimo, não permitindo ao autor obter nenhum alívio. Entretanto, conforme mencionado acima, se Byron em nada ajudava a melhora do estado de espírito de Mill, Wordsworth surpreendia positivamente o autor ou em suas palavras: Wordsworth era justamente o que eu precisava ${ }^{190}$. Mill descobriu os prazeres da leitura de Wordsworth através de sua leitura em poemas compilados em uma edição em dois volumes publicada em $1815^{191}$.

Esses poemas afetavam uma de suas sensibilidades mais prazerosas, a saber: o amor pelas coisas rurais e pela paisagem natural. Tanto a beleza rural quanto as paisagens naturais exerciam um poder bastante forte sobre Mill e eram associados aos prazeres que obtivera quando, anteriormente, fizera sua excursão pelos Pirineus.

\footnotetext{
${ }^{188}$ Poeta romântico inglês.

${ }^{189}$ Mill, 1873, p. 133.

${ }^{190}$ Mill, 1873, p. 134.

${ }^{191}$ Embora de fundamental valor para que o autor pudesse sair de sua crise mental, o autor ressalta que tal miscelânea de poemas acrescentou pouco valor em etapas posteriores de sua vida.
} 
Entretanto, não foi apenas o apelo às paisagens naturais e rurais que despertaram emoção em Mill e o fez sair de seu estado apático de ânimo, pois se assim fosse Mill ressalta que Scott, outro poeta que descreve paisagens poderia ter feito o mesmo, ou mesmo algum paisagista de segunda linha. A diferença de Wordsworth para Scott e alguém que retratasse apenas paisagens estaria no fato de que Wordsworth não expressava apenas beleza exterior, mas também estados de sentimentos e estados mentais misturados a sentimentos, sob o estímulo da beleza retratada nas paisagens naturais e rurais [Mill, 1873, p. 135]. Os prazeres proporcionados pela leitura de tais poemas pareciam ser uma própria fonte de alegria interior, uma espécie de prazer criador que poderia ser compartilhado por todos os seres humanos. O prazer causado através de tal leitura não parecia possuir relação com esforço ou imperfeição, mas poderia enriquecer-se por meio de qualquer aperfeiçoamento na condição social da humanidade ${ }^{192}$. Lendo os poemas de Wordsworth, Mill sentiu-se mais feliz. O autor acreditava que houve em seu tempo poetas superiores a Wordsworth, entretanto, outro tipo de poesia não teria feito o que seus poemas fizeram por ele. Nas palavras do autor:

"Eu precisava de algo que me fizesse sentir que havia uma felicidade real e permanente na contemplação serena" [Mill, 1873 , p. 135,]

O prazer associado à cultura deste tipo de leitura estava, enfim, seguramente estabelecido e não haveria mais nada a temer, no que diz respeito ao cultivo do hábito da análise, pois associações a objetos constantes de prazer estavam firmemente estabelecidas e uma mente analítica só viria a somar, no que diz respeito à busca do conhecimento, não representando risco para os sentimentos. Ao final da coletânea de poemas, Mill descobriu que Wordsworth também havia sido acometido pelo mesmo tipo de mal do qual ele havia sido vítima e, da mesma forma, ele havia buscado refúgio na poesia. A partir do estímulo de seus sentimentos ${ }^{193}$, que se iniciou com a leitura das Memórias de Marmotel e teve prosseguimento com a leitura de poetas como Wordsworth, Mill conseguiu, de forma gradual, superar seu abatimento, sua crise, até o ponto em que nunca mais retornou ao

\footnotetext{
192 Mill, 1873, p. 135.

${ }^{193}$ É importante notar que a linha divisória entre sentimentos e estados mentais para Mill é sempre bastante tênue, dada sua definição apresentada logo no início desta tese (nota 1). Sentimentos são um estado mental.
} 
estágio em que se encontrara. Mill superou sua crise completamente, tendo denominado Wordsworth de o poeta de espíritos prosaicos que possuem gostos serenos e contemplativos. Para Mill era exatamente este tipo de poeta que precisava de cultivo poético $^{194}$.

A leitura de Wordsworth havia convencido Mill quanto à transformação que aquele tipo de arte poderia gerar no caráter de indivíduos e isto lhe servia de pretexto para pronunciar-se publicamente quanto às modificações em seu novo modo de pensar. Ao mesmo tempo se afastava dos antigos companheiros intelectuais, pois estes não haviam sido expostos a tais modificações.

Tais modificações no modo de pensar de Mill ainda eram acompanhadas de uma rejeição pela obra de Byron, tanto pela qualidade deste como poeta como pela influência que exercia no caráter $^{195}$ dos indivíduos. Roebuck, um amigo de Mill, ao contrário, possuía forte admiração por Byron, pois segundo este autor, a poesia de Byron era a poesia sobre a vida humana, enquanto a poesia de Wordsworth era a poesia das flores e das borboletas ${ }^{196}$. Mill, então, decidiu confrontar, por duas tardes, suas opiniões com as do amigo na Debating Society, a fim de ponderar os méritos de Byron e Wordsworth a partir da defesa de teorias acerca da poesia, ilustrando-as com longas declamações. O amigo de Mill tinha amplo gosto pela pintura, música e teatro, sendo ele mesmo capaz de pintar com facilidade. "Mas nunca foi possível fazê-lo perceber que essas coisas possuem algum valor para a formação do caráter”. [Mill, 1873, p. 137].

Roebuck, amigo de Mill, era um benthamista. Como se poderia supor do modelo de indivíduo teórico de Bentham, Roebuck poderia ser um homem frio, sem sentimentos, no entanto, conforme Mill descreve Na Autobiografia, seu amigo era dotado de intensos sentimentos, mas assim como a maioria dos ingleses, tentava suprimir esses sentimentos, sendo muito mais suscetível a simpatizar com a dor do que com o prazer. Uma vez que de acordo com Mill, Roebuck era um inglês típico, que buscava a felicidade por outros meios que não através das simpatias e cultivo dos sentimentos, sendo incapaz de valorizar as emoções ativas das simpatias, pois segundo o autor:

\footnotetext{
${ }^{194}$ Mill, 1873, p. 136.

195 Ibid.

${ }^{196}$ Ibid.
} 
"O caráter inglês e as condições sociais inglesas tornam tão difícil obter a felicidade pela prática das simpatias, que não é de admirar que estas contem pouco no modo de vida de um inglês. Na maioria dos outros países a importância suprema das simpatias, como elemento da felicidade individual é um axioma que se dá por suposto e que não necessita de nenhuma exposição formal.

De acordo com Mill ${ }^{198}$ a maioria dos pensadores ingleses considerava os sentimentos como males necessários para que fossem auferidos os benefícios da benevolência e compaixão. Roebuck não era um inglês diferente, pois não via nenhum bem no cultivo dos sentimentos (além dos acima citados), ainda mais se estes sentimentos fossem acompanhados de elementos imaginativos, que segundo o amigo de Mill só serviam para formar ilusões. Mill tentou convencer seu amigo, sem nenhum sucesso, de que a emoção imaginativa que uma idéia excita nos seres humanos quando formada de maneira vívida, não é uma ilusão, mas um fato tão real quanto qualquer outra qualidade de outro objeto e não é, também, um fato contraditório ou excludente em relação ao conhecimento mais preciso ou exato. [Mill, 1873, p.138].

Considerando uma nuvem, seria possível ser sensível à beleza do sol nascendo e iluminando-a e ao mesmo tempo considerar que a nuvem é constituída por vapor de água e que, portanto, está sujeita a todas as leis dos vapores em estado de suspensão. Não haveria nenhuma contradição em admirar a nuvem quanto à sua feiúra ou beleza e, desta forma, acionar a imaginação e ao mesmo tempo aceitar as leis dos vapores em estado de suspensão.

Devido a essas e outras divergências teóricas Mill teve sua amizade diminuída com Roebuck, ao mesmo tempo em que estreitava laços com coleridgeanos como Frederick Maurice e John Sterling. Destes dois amigos, Maurice era o pensador, e Sterling o orador apaixonado expositor das idéias que eram formuladas por Maurice.

Entretanto, Mill ressalta que o poder intelectual de Maurice não foi utilizado para realizar o progresso do conhecimento, mas antes para construir provas a fim de tentar estabelecer que a Igreja Anglicana conhecia tudo desde sempre, e que todos os

${ }^{197}$ Mill, 1873, p. 137.

${ }^{198}$ Mill, 1873, pp. 137-138. 
ataques dirigidos à Igreja Católica não eram apenas consistentes com os Trinta e nove $\operatorname{artigos}^{199}$, mas eram ainda melhor descritos nesses artigos do que por alguém que os recusasse.

Outros autores de maior envergadura que influenciaram Mill de maneira diferente da forma analítica de pensar, ou até de modos distintos a um modo utilitarista de compreender questões filosóficas foram Coleridge ${ }^{200}$ e Goethe:

"Embora minhas conversas com Maurice fossem quase sempre discussões, extraí delas muitas coisas que me ajudaram a construir um novo edifício de pensamento, da mesma forma que extraí muito de Coleridge e das obras de Goethe e de outros alemães" [Mill 1873, p. 139].

Mill ressalta que as influências do modo de pensar europeu, do pensamento continental, e especialmente aquelas que representavam a reação do século XIX contra o XVIII, tornavam-se marcantes sobre ele. De acordo com o autor elas vinham de vários lados, como por exemplo: “dos escritos de Coleridge que ele havia começado a ler [...]”; [Mill,1873, p. 144], dos primeiros escritos de Carlyle na Edinburgh e na Foreign Review.

Uma vez entendida como deu-se a superação da crise mental de Mill, a saber: aos poucos a partir, da valorização, excitação dos sentimentos, da leitura de poetas como Wordsworth e Goethe e do contato com novas idéias como as de Coleridge, o autor sentiu que suas velhas idéias estavam cedendo em muitos pontos. Em suas palavras:

"Descobri que o edifício de minhas velhas opiniões recebidas estava cedendo em muitos pontos, mas nunca deixei que ele se desfizesse em pedaços, ocupando-me incessantemente em reconstruí-lo com novos materiais" [Mill, 1873, p.141]

\footnotetext{
${ }^{199}$ The Thirty-niny articles. Aprovados em 1571, condensam o credo da Igreja Anglicana.

${ }^{200}$ Filósofo e poeta inglês, influenciou Mill no que diz respeito aos dois aspectos (poesia e filosofia, embora tenha muitos pontos de sua filosofia que ele discorde). Isto é provado não apenas porque consta de sua Autobiografia, mas também porque Mill escreveu um ensaio sobre Coleridge.
} 
$\mathrm{O}$ autor ressalta que durante todo esse período contentou-se em permanecer confuso e vascilante, sempre que tinha uma nova idéia pretendia conformá-la ao corpo de suas idéias antigas, tendo em vista a maneira como essa nova idéia alteraria o todo delas.

Como exemplo de nova idéia de Mill, tem-se o método em ciências morais que o autor desenvolveu. O desenvolvimento de tal método foi estimulado pela defesa que teve que formular no que diz respeito ao conflito sobre a doutrina do governo de seu pai e de Bentham expostas nos escritos de ambos, pois tanto a familiaridade com métodos dos dois autores quanto o conhecimento de outros métodos de fazer política e ciência o fazia pensar que a política não podia ser uma ciência da experiência específica, nem tão pouco uma ciência de verdades a priori e que as críticas feitas contra a teoria de Bentham, acusando-o de proceder a priori mediante raciocínios gerais e não por meio de experimentações baconianas ${ }^{201}$, mostraram uma certa ignorância dos princípios de Bacon e das condições necessárias para aplicação da investigação experimental [Mill, 1873, p.142]. Ao mesmo tempo em que Mill ponderava qual era o correto método de realizar ciência política, social, Macaulay escreveu na Edinburgh Review um famoso ataque contra o Ensaio sobre o governo de James Stuart Mill, contra o método empírico de tratar os fenômenos políticos, sendo que nem uma boa noção do método empírico ele possuía, pois apesar de conhecer Kepler, excluía Newton e Laplace. Embora Mill reconhecesse que o artigo estivesse incorreto em suas críticas, havia nele verdade em várias críticas e isto estimulou Mill a pesquisar qual seria o método mais adequado às ciências sociais.

Para encontrar um método adequado para as ciências morais Mill revisou o método da física, dinâmica e química. Na dinâmica ele pôde encontrar a composição de forças como o mais completo exemplo de processo lógico que ele investigou. Quando examinou o que a mente faz quando aplica o método da composição de forças ele entendeu que a mente efetua um simples ato de adição. A mente humana adiciona e separa o efeito de uma força ao efeito de outra força e coloca como efeito resultante a soma destes efeitos separados. Este método é passível de ser utilizado na dinâmica e em outros ramos da física matemática, mas na química não. A diferença entre fenômenos químicos e físicos estava logo na introdução de seu livro preferido de química da adolescência, O Sistema de Química, de Thomson. Esta distinção permitiu que Mill

${ }^{201}$ Mill, 1873, p. 141-142. 
entendesse o que o deixava sem compreensão quanto ao método das ciências políticas, sociais . Do método químico e dinâmico o autor chegou à conclusão de que uma ciência ou é experimental ou dedutiva, desta forma, tanto Macaulay quanto seu pai estavam errados. Macaulay porque afirmava que uma ciência política era experimental e isto significava que não admitia deduções, mas apenas experimentos com seres humanos (o que mais tarde Mill provará ser impossível controlar experimentos com os seres humanos) e James Mill porque apesar de ter escolhido o método correto, a saber: o método dedutivo, havia cometido o erro de selecionar um em especial; o método da Geometria pura ${ }^{202}$, ciência que quando se pensa em axiomas não admite adição ou composição de efeitos. Sob esta exclusão dos métodos químicos e geométricos como base para as ciências sociais e aceitação do método de composição de forças presente na dinâmica, uma base sólida se formou para os principais capítulos que publicou em seguida sobre o nome de a Lógica das Ciências Sociais.

Portanto, durante o período de sua crise mental Mill chegou a muitas importantes conclusões no que concerne à sua filosofia moral ${ }^{203}$. Além da compreensão que a arte, como a poesia (especialmente de Wordsworth) e a música eram de fundamental importância para a formação do caráter de um indivíduo. As influências do pensamento continental europeu e especialmente aqueles pensamentos que representavam uma reação do século XIX contra o século XVIII, conforme mencionado acima, exerciam uma presença marcante nas considerações filosóficas do autor. Conforme mencionado anteriormente, estas influências vinham dos escritos de Coleridge que Mill havia começado a ler antes mesmo de sua mudança de opiniões; dos coleridgianos com quem o autor mantinha relações pessoais, daquilo que havia lido de Goethe, dos artigos de Carlyle, além do conhecimento de obras francesas dessa época. Dessa última, o autor derivou a idéia de que a mente humana possui uma certa ordem de progresso humano possível, e que qualquer filosofia ou teoria geral da política supõe esta teoria prévia do progresso humano ou o que é o mesmo em outras palavras; uma filosofia da história, isto significa dizer que algumas coisas precedem outras. Tendo em vista que é possível realizar uma filosofia da história ou uma teoria geral da política é possível concluir que

\footnotetext{
${ }^{202}$ Vide Livro VI do Sistema de Lógica de Mill. Isto será trabalhado no próximo capítulo, o método das ciências sociais, o método dedutivo inverso que embasa a moralidade (uma arte de dar preceitos).

${ }^{203}$ Mill, 1873, p. 144.
} 
os diferentes estágios do progresso humano requererão diferentes instituições, embora em um mesmo estágio do desenvolvimento humano, as mudanças possam ocorrer, mas não de forma ilimitada [Mill, 183, p. 145]. Entretanto, para pressupor uma filosofia da história é necessário pressupor que o indivíduo está apto a progredir ao longo do tempo, em outras palavras, isto é o mesmo que dizer que o individuo não está trancado em um modelo estático (analogia com equilíbrio da física), mas ele pode aprender e melhorar ao longo do tempo (modelo dinâmico - analogia com movimento da física). Desta forma, a história muda, assim como os indivíduos também possuem um modelo que lhes permite uma mudança (dinâmica).

Os autores que influenciaram Mill neste modo de pensar, quanto a uma filosofia da história que permitiria o progresso (entendido como mudança nas instituições sociais), bem como estabelecer um modelo de indivíduo que fosse dinâmico, que o indivíduo pudesse melhorar, transformar-se com o tempo, pertenciam, principalmente, à escola sansimoniana, da França. Mill conheceu os primeiros escritos dos sansimonianos em 1829 e 1830, quando estavam apenas contestando a propriedade hereditária sem elaborar seu projeto socialista de fato. Nas palavras de Mill:

"Eu não estava, de forma alguma, preparado para acompanhá-los tão longe, mas fiquei muito impressionado com a visão que propunham, e que era apresentada a mim pela primeira vez, a respeito da ordem natural do progresso humano e, especialmente, com a divisão da história em períodos orgânicos e períodos críticos". [Mill, 1873, p. 146]

Quando os homens encontram-se sob os períodos orgânicos aceitam com convicção algum credo positivo que serve para julgar seus atos. Os períodos orgânicos, com suas crenças positivas, influenciam os homens e estes progridem de modo compatível com estas crenças até que cheguem a superá-las. Após este período, há um período de crítica e negação das crenças passadas (período crítico), sem que a humanidade tenha adquirido novas crenças que tenham um caráter de generalidade ou normatividade, exceto a convicção de que as crenças antigas são falsas. Por exemplo, o período do politeísmo grego e romano foi um período orgânico (com firmes crenças normativas estabelecidas), sucedido pelo período crítico ou cético, como Mill o 
denomina $^{204}$, dos filósofos gregos (com negação das crenças passadas, sem ter uma única crença ou conjunto de crenças para substitui-lo). O cristianismo constituiu outro período orgânico (com um conjunto estabelecido de crenças), sendo que seu período crítico correspondente foi a Reforma, e naquele momento, Mill relatava que as pessoas ainda estavam vivendo a reforma, período que não cessaria enquanto não fosse substituído por outro período orgânico de credo mais avançado, pois nesta substituição pressupõe-se a noção de progresso. O autor relata que essas idéias eram de toda a Europa, embora cabia aos sansimonianos o mérito da sistematização, do maior rigor, da distinção do período orgânico para o crítico.

No que se refere às publicações dos sansimonianos houve uma que pareceu a Mill muito superior às demais e em que a tese central havia mostrado-se superior às demais. Tratava-se da obra de Auguste Comte.

"Mas eu pensei que os sansimonianos formulavam, de forma mais serena e filosófica, tudo o que havia de verdade nessas denúncias. Entres suas publicações houve uma que me pareceu muito superior às demais e em que a idéia geral havia se desenvolvido em algo muito mais definido $e$ instrutivo. Tratava-se de uma obra inicial de Auguste Comte $^{205 ",}$

Mill tomou contato pela primeira vez com a doutrina da sucessão natural de três estados em todas as ordens do conhecimento, incluindo a ordem social, através da leitura de seu Système de Politique Positive. Os estados sociais seriam: primeiro o teológico, depois o metafísico e, por fim, o estado positivo. Efetuando uma análise histórica seria possível afirmar que com o fim do estado feudal (cristão) teria ocorrido o fim do estado teológico, com a Reforma e Revolução Francesa teria ocorrido o fim do estado teológico e início do estado metafísico, sendo que Mill ressaltava que, em seu período histórico, o estado positivo ainda estaria por vir. A doutrina da transição de opiniões seja de períodos orgânicos para períodos críticos, seja conforme Comte teoriza, de um período teológico, para um período metafísico, para um período positivo veio de encontro com a metodologia que Mill tinha em vista para tratar as ciências sociais,

\footnotetext{
${ }^{204}$ Mill, 1873, p. 146.

${ }^{205}$ Curso de Filosofia Política (1824).
} 
metodologia esta que seria extraída da ciência física, tanto por admitir a adição de várias causas para explicar um mesmo fenômeno, quanto pela noção de mobilidade histórica (e mesmo do indivíduo, como é tese deste trabalho, o indivíduo apresenta um modelo dinâmico), conforme será visto no capítulo terceiro desta tese. Entretanto, Mill não se contentou com a teoria exposta e pensou ser possível aliar as melhores qualidades dos períodos orgânicos com os períodos críticos ${ }^{206}$, quais sejam: uma firme convicção do que é certo e errado, do útil e pernicioso, convicções estas gravadas por associações de ações com sentimentos de prazer (quando correta) ou de dor (quando errônea) na primeira educação, além de fundamentados na razão de tal forma que não mais precisassem ser substituídos por outros credos, nem por credos de natureza religiosa; as melhores qualidades deste período orgânico seriam misturadas às melhores qualidades do período crítico que seria; plena liberdade de pensamento, irrestrita liberdade individual desde que não se tornasse prejudicial aos demais [Mill, 1873, p. 148]. É possível notar como Mill dá importância aos sentimentos (ligada à primeira educação) como forma de aprofundamento da compreensão daquilo que se quer ensinar e isto não impede que se tenha um entendimento também racional do tema.

De acordo com Mill, os sansimonianos ainda desenvolveram uma crítica bastante pertinente ao liberalismo, segundo à qual colocava em questão o valor ilimitado e irrestrito que a economia política dava à propriedade privada e à herança, além de criticar aquilo que a economia política considerava como da mais elevada importância para o aperfeiçoamento social, a saber: a liberdade de troca e de produção. As afirmações dos sansimonianos referiam-se ao fato de que o trabalho e o capital da sociedade deveriam ser administrados de acordo com o interesse geral da comunidade, sendo que cada indivíduo participaria de acordo com suas capacidades (como pensador, mestre, artista, produtor, etc) e seriam remunerados de acordo com suas obras. Mill estava em contato com essas idéias através dos escritos de Gustave d'Eichtal, Bazard e Enfantin, uma vez que havia perdido Auguste Comte de vista por alguns anos [Mill, 1973, p. 148]. Embora Mill nunca tivesse acreditado nem na possibilidade prática, nem no funcionamento benéfico dessa estrutura, ele entendia e sentia que a proclamação de tal ideal de sociedade humana colocava um profícuo sentido aos esforços dos membros de

${ }^{206}$ Críticas misturadas a convicções. 
uma sociedade ${ }^{207}$. Além disso, havia a proclamação da perfeita igualdade entre homens e mulheres pelos sansimonianos, como Owen e Fourier, na qual os indivíduos da sociedade presente e futura deveriam mirar como meta de transformação da sociedade.

O contato com essas novas idéias proporcionou a Mill, ao mesmo tempo, a revisão das antigas verdades que sustentava e sua reconciliação com estas, uma vez que toda nova idéia que Mill considerasse interessante não era nunca abandonada pelo autor, mas antes incorporada e reconciliada a seu sistema, através da revisão das antigas verdades por ele sustentadas. Entretanto, é possível concluir que de todos estes autores considerados sansimonianos a mais importante influência para o autor foi Auguste Comte $^{208}$.

Um dos fatores que serão bastante importantes para entender o método das Ciências Sociais e, portanto, para compreender a base da formação do caráter dos indivíduos e que pesava sobre um dos momentos de abatimento de Mill referem-se à doutrina da necessidade filosófica. Para o autor, de acordo com esta doutrina era como se estivesse cientificamente provado que os homens não teriam poder para influenciar as circunstâncias que formam o seu caráter. Seria como estivessem dadas ou determinadas as circunstâncias antecedentes formadoras do caráter dos indivíduos. Esta era a compreensão do autor a respeito desta doutrina até o momento de sua crise mental e repetia a si mesmo que seria um alívio caso pudesse deixar de acreditar na doutrina da formação do caráter pelas circunstâncias. Após alguma reflexão o autor chegou à conclusão de que era o nome necessidade que gerava confusão a respeito da doutrina das circunstâncias como determinantes do caráter dos indivíduos. Pois, apesar de ser possível conhecer, com certeza, quais são as causas que determinam o caráter de um indivíduo, isto não significa que o desejo de um indivíduo não possa ser preponderante para influenciar as circunstâncias que formarão seu caráter:

"que a convicção de que temos um poder real sobre a formação de nosso próprio caráter era o que havia de verdadeiramente nobre e inspirador na doutrina do livrearbítrio, e que a nossa vontade, influindo em algumas de

\footnotetext{
${ }^{207}$ Note que a palavra ideal na concepção Kantiana significa um fim nunca atingido, mas passível de ser perseguido.

${ }^{208}$ Embora tenha abandonado os sansimonianos.
} 
nossas circunstâncias, pode modificar nossos hábitos futuros e nossas capacidades. Tudo isso era plenamente consistente com a doutrina das circunstâncias, ou melhor ainda, era a própria doutrina entendida de forma correta". [Mill, 1873, p.150].

O desejo e o fato dos indivíduos poderem mudar as circunstâncias que moldavam o seu caráter, apesar de ser possível conhecer com certeza as causas que geraram um determinado caráter, era a própria doutrina da necessidade entendida corretamente. O fatalismo seria, assim, afastado por completo da doutrina da necessidade, sendo que a compreensão desta teoria traria um completo entendimento e alívio para alguém que se propunha a interferir na formação dos caracteres através da modificação das circunstâncias, para alguém que pretendia ser um reformador do mundo, como Mill $^{209}$.

De acordo com Mill, um mesmo tipo de mudança de opinião pairava sobre ele no que diz respeito à questão política, de qual seria a melhor forma de governo, pois já não mais aceitava como teoria científica a doutrina contida no Ensaio sobre o Governo. O autor continuava a pensar que a melhor forma de regime político era a democracia, conforme ressalta [Mill, 1873, p. 151]: "Continuei sendo, como sempre fora, um radical e um democrata para a Europa e, especialmente, para a Inglaterra". Entretanto, não sabia se a democracia representativa consistia na melhor forma de governo, absolutamente, pois ela dependia do tempo e do lugar a ser implementada. No caso inglês, o autor considerava o maior problema o fato de que o governo estivesse dominado por aristocratas, ricos, enquanto que a grande maioria não possuía representação no governo. Por considerar, no momento em que escreveu a Autobiografia que a questão política consistia mais em uma questão moral e educativa do que de riqueza, Mill pensava ser importante que doutrinas contrárias à propriedade como a dos sansimonianos e do owenismo disseminassem-se pela Europa, menos porque acreditasse que pudessem ser postas em prática e mais porque desejasse que aqueles que estivessem apropriando-se privadamente do bem público considerasse a importância de educar o povo e de dar poder a ele através da democracia.

${ }^{209}$ Mill, 1873, p151. 
No que concerne aos escritos de Mill é relevante comentar aquilo que Mill escreveu durante estes anos, independentemente de suas contribuições para a Edinburgh Review ou ao Examiner, pois neste momento (1831) o autor escrevera para este último o artigo intitulado "O espírito da época" tecendo comentários a respeito do males que são ocasionados quando ocorre transição de um sistema de opiniões para outro. Tais artigos eram inspirados pela Revolta Francesa de Julho (de 1830).

Entre 1830 e 1831 o autor escreveu os cinco ensaios publicados depois com o título Ensaios sobre algumas questões não resolvidas da economia política, entretanto, em 1833 reescreveu parcialmente o quinto ensaio. Eles foram impressos em 1843, após o êxito do Sistema de Lógica. Um dos assuntos referentes à lógica que mais inquietaram Mill referem-se ao paradoxo da descoberta de verdades mediante ao uso de raciocínio geral, a questão toda era descobrir como alguns axiomas poderiam resultar em novas verdades (que o raciocínio poderia ser formulado em silogismo não cabia dúvida, nem tão pouco que a conclusão estaria contida nas premissas). Mill pôde resolver esta dúvida central a partir da leitura do volume segundo sobre o raciocínio de Dugald Stewart. Dessa leitura seguiram-se seus escritos quanto à teoria do silogismo presente no segundo capítulo do Sistema de Lógica, após incorporar essa teoria do silogismo, Mill escreveu o primeiro livro do Sistema de Lógica, escrevendo, posteriormente, a teoria das espécies que serviu de base para o terceiro livro Após escrever estes livros sobre a lógica o autor fez, então, uma pausa de cinco anos. Relata Na Autobiografia ${ }^{210}$ que estava esgotado e que não podia elaborar nada de satisfatório a respeito da indução, embora tenha continuado lendo livros que pareciam esclarecê-lo sobre o assunto.

Ainda no que concerne aos escritos do autor, sabe-se que Mill escreveu diversos artigos (em 1832) que diziam respeito aos direitos e deveres do Estado no que concerne à propriedade das corporações e da Igreja para a Tait's Magazine e para a Jurist, incluídos em uma coletânea denominada Dissertações e Discussões e outro que dizia respeito a um tema denominado a "falácia monetária" escrito somente para a Jurist. $\mathrm{O}$ artigo escrito somente para a Jurist insistia no fato de que a oferta educacional não podia ser deixada ao sabor da demanda dos pais dos consumidores de educação, mas deveria ser mantida a níveis superiores pelo Estado.

${ }^{210}$ Ibid, 1873, p.159. 
"Todas essas idéias foram confirmadas e fortalecidas pelo curso de minhas reflexões posteriores" [Mill, 1873, p. 160].

No que concerne à vida pessoal de Mill, é possível depreender que ela parece ter sido vazia até então, deixando de lado sua relação com seu pai (que era mais intelectual do que afetiva), bem como sua relação com as pessoas que se tornavam seus colegas. Mill sempre parecia estabelecer relações mais intelectuais do que afetivas com as pessoas. Entretanto, após o encontro com Harriet Taylor, antes que seu relacionamento com ela tivesse se tornado íntimo ou confidencial, o autor descreve $\mathrm{Na}$ Autobiografia que ela era a pessoa mais admirável que ele havia encontrado.

"A mesma precisão e rapidez de operação que impregnava tanto sua sensibilidade como sua inteligência, aliada a seus dotes de sentimento e imaginação, poderiam ter feito dela uma artista consumada; da mesma forma que sua alma ardente e terna e sua vigorosa eloqüência, uma grande oradora; assim como seu profundo conhecimento da natureza humana, discernimento e sagacidade na vida prática, se este tipo de carrièrre fosse acessivel às mulheres, teria sido um dos mais eminentes líderes da humanidade". [Mill, 1873, p.163]

Ainda sobre Harriet Taylor, Mill ressalta que a imaginação de sua mais próxima amiga permitia uma plena identificação de seus sentimentos com os dos demais indivíduos, tal identificação marcava um traço de sua personalidade denominado altruísmo que resultava, portanto, antes desta identificação de sentimentos próprios com os demais, com o auxílio da imaginação, do que do aprendizado de qualquer sistema de deveres. Não obstante a imaginação representar importante papel para a formação de um bom caráter, o intelecto também estava a serviço de tudo que pudesse auxiliar a formação de seu caráter moral, descrito por Mill, como o mais nobre e ponderado que já havia encontrado em sua vida ${ }^{211}$. As qualidades que Mill elencava como sendo componentes de seu nobre caráter eram as que seguem: a paixão pela justiça, ilimitada generosidade, a modéstia, sublime altivez, simplicidade, sinceridade, o máximo de desprezo por tudo que

${ }^{211}$ Mill, 1873, p. 163. 
fosse vil e covarde e uma completo indignação por tudo que fosse brutal e tirânico, desleal e desonroso.

A influência de Harriet Taylor foi importante para moldar, de certa forma, o caráter de Mill e mesmo quando chegou a dirigir seu progresso mental o fez de forma que não alterasse seu caminho, mas apenas e tão somente ajudasse a segui-lo com mais determinação e quando necessário com mais cautela ${ }^{212}$. Mill descreve que as únicas mudanças relevantes de opinião que ocorreriam em seu pensamento diziam respeito à política e consistiram à aproximação de um socialismo qualificado, bem como à aproximação de uma forma modificada da democracia pura, exposta em suas Considerações sobre o Governo Representativo.

A última mudança de Mill no que concerne à teoria da democracia identificava falhas deste governo resultantes do perigo ocasionado pela maioria numérica, capaz de oprimir a minoria resultante deste sistema, sendo a evolução deste sistema um resultado do próprio progresso humano, de acordo com o autor. Além de identificar estas falhas neste regime de governo, o autor pretendia efetuar defesas necessárias para proteger o sistema, bem como correções que deveriam ser adicionadas a este regime. Em outras palavras, seria necessário conservar as tendências benéficas da democracia e corrigir as falhas que este sistema ocasionasse e toda essa problematização Mill encontrou exposta, com clareza, por sua leitura da obra Democracia da América de Tocqueville.

O credo político de Mill caminhou cada vez mais nesta direção como se pode notar quando se compara sua primeira resenha Democracia na América, escrita e publicada em 1835, com a de 1840 (reimpressa nas Dissertações) e esta última com as Considerações sobre o governo representativo. Um tema relacionado a este, do qual Mill obteve grande benefício com o estudo de Tocqueville, foi a questão fundamental da descentralização. A idéia principal era a de que a prática popular era a mais importante contra os males que o governo central da democracia poderia ocasionar, ou seja a atividade política e prática do cidadão individual era considerada como algo que não só constituía um dos meios mais eficazes para educar os sentimentos sociais e a inteligência

${ }^{212}$ Mill, 1873, p. 164. 
prática do povo $^{213}$, elementos que eram considerados fundamentais para o bom governo e como proteção contra uma democracia absoluta. Considerando a questão fundamental da descentralização, o próprio povo, deveria realizar atividades sociais de ordem coletiva, descartando, desse modo, a intervenção do governo executivo, sempre que possível. Entretanto, Mill via alguns exageros no abuso de descentralização, como o excessivo descolamento entre poder local e central (por exemplo em sua época, nove em cada dez assuntos de ordem interna que em outras partes eram controlados pelo governo, estavam nas mãos de agências independentes deles, podendo até mesmo impedir o exercício benéfico da autoridade legislativa, contra algum abuso local). Desta forma, Mill tentava denunciar ambos os excessos (a falta quase que completa de centralização e os males decorrentes do excesso de centralização do governo). Portanto, Tocqueville foi outra importante influência para Mill, especialmente no que se refere às idéias sobre democracia.

A maioria das influências destacadas neste trabalho foi positiva no sentido de que Mill reconheceu a influência positiva de suas leituras, enquanto ele diz que Sedgwick, um homem de particular autoridade em ciências naturais não deveria ter se pronunciado a respeito de filosofia analítica e moral ${ }^{214}$. Ele havia publicado o Discurso sobre os estudos de Cambridge, atacando Locke e Paley contra a psicologia analítica e a ética utilitarista. O livro havia gerado grande indignação em seu pai, na opinião de Mill totalmente justificada. Através desta oportunidade, Mill havia aproveitado para repelir o ataque e defender o utilitarismo.

Portanto, é possível concluir que Sedgwick não será importante fonte de influência em assuntos morais para Mill, embora o autor respeitasse seu trabalho em ciências naturais.

Voltando à contribuição de James Mill e de Bentham, John Mill assume que se fizesse uma comparação entre ambos o trabalho de Bentham teria contribuído muito mais para o bem comum do que o de seu pai, mas mesmo assim haveria um lugar eminente na história da Inglaterra, que naquele momento lembrava pouco de seu pai, de acordo com John Stuart Mill. De acordo com o autor, isto ocorria devido a duas causas

\footnotetext{
${ }^{213}$ Mill, 1873, p. 167.

${ }^{214}$ Ibid p. 173.
} 
principais $^{215}$ : a) primeiramente porque ele era apenas um mero seguidor de Bentham, isto porque o autor era um dos mais originais do seu tempo, James Mill foi um dos primeiros a apreciar e adotar os seus mais importantes pensamentos. Entretanto, ambas as mentes eram bastante diferentes. James Mill não possuía as mais altas qualidades de Bentham e vice-versa. De acordo com Mill, não se poderia lograr para seu pai tudo que Bentham conquistou no campo teórico e prático, uma vez que este foi o fundador do princípio de utilidade, e da escola de seguidores de todas as conseqüências que acarretaram a formulação deste princípio (sejam elas, na política com a criação e consolidação da democracia liberal, na legislação e direito, ou na economia servindo de fundamento para a economia neoclássica). Seu pai não revolucionou ou criou esses grandes ramos do pensamento humano. Embora em uma certa medida de conhecimento seu pai deveria ser conhecido, pois foi justamente neste ramo do conhecimento que Bentham não se aventurou, a saber: a psicologia analítica, a qual, de acordo com Mill, toda a moralidade e as ciências políticas estão ancoradas e terão uma marca fundamental nos estágios do progresso humano. Mill ressalta que se deve entender por leis da mente, aquelas que se referem ao fenômeno mental dos vários sentimentos ou estados de consciência do ser humano. Estes consistem em pensamentos, emoções, volições e sensações. É usual, entretanto, falar em sensações como estado do corpo, não da mente. Contudo, esta é uma confusão comum, qual seja: a de dar um único nome a um fenômeno e à sua causa próxima $^{216}$.

O antecedente imediato da sensação é um estado do corpo, mas a sensação, ela própria, é um estado da mente. Se a palavra mente significa alguma coisa, ela significa aquilo que sente. $\mathrm{O}$ autor diz que qualquer opinião que se tenha a respeito da identidade ou diversidade fundamental do termo mente, em qualquer caso a distinção entre fatos mentais e físicos, entre mundo externo e interno, sempre permanecerá como assunto de classificação, sendo que nesta classificação as sensações, como todos os outros sentimentos, devem ser colocados como fenômenos mentais. O mecanicismo de suas produções, ambas no corpo e no que é chamado natureza exterior, é o que pode ser

\footnotetext{
${ }^{215}$ Ibid (edição Liberty Fund, p. 208)

${ }^{216}$ Mill, 1843, (do livro A Lógica das Ciências Morais, 1999, p. 47)
} 
classificado como físico ${ }^{217}$. Desta forma, pode-se concluir que a mente é algo que sente e o mecanicismo da produção destas sensações (aquilo que antecede as sensações) ocorre no corpo. Os fenômenos da mente, então, são constituídos em pensamentos, emoções, volições e sensações.

Torna-se importante notar que essas conclusões extraídas do livro sexto do Sistema de Lógica de John Stuart Mill a respeito do que o autor entende por leis da mente não foram formuladas apenas pela leitura dos escritos de seu pai sobre psicologia analítica, conforme mencionado, os escritos de Berkeley, Hume, Reid, Dugald Stewart e Brown foram fundamentais para que Mill chegasse a essas conclusões. Ir-se-ia mais longe nesta tese e dir-se-ia que o autor estaria elaborando seu modelo de indivíduo dizendo que um dos fatores fundamentais para a elaboração deste modelo é que se leve em consideração que a mente possui certas leis determinadas. De acordo com o autor os estados da mente ou são causados ou por outros estados da mente, ou por estados do corpo. Quando um estado da mente é gerado diretamente por um estado do corpo, a lei é uma Lei do Corpo e deve ficar restrita ao âmbito da ciência física ${ }^{218}$. Quando um estado da mente é produzido por outro estado da mente, a lei refere-se ao caso de uma Lei da Mente. Utilizando o método da indução, que será melhor explicado no próximo capítulo, é possível afirmar que existe uma ciência da mente. Sem esta, produzir-se-iam conclusões errôneas em partes importantes da ciência da natureza humana.

Desta forma, entende-se que:

"a Psicologia tem, então, por objeto as uniformidades de sucessão, as leis, últimas ou derivadas, de acordo com as quais um estado mental sucede o outro - é causado por outro ou, pelo menos, cuja causa o faz seguir outro estado mental. Dessas leis, algumas são gerais, outras mais especiais. As que seguem são exemplos das leis mais gerais. "219

A primeira lei elencada por Mill, na mesma linguagem de Hume, ressalta que toda impressão mental tem sua idéia ou em outras palavras isto significa afirmar

${ }^{217}$ Mill, 1999 (1843) p. 47

${ }^{218}$ Mill, 1999 (1843) p. 48.

${ }^{219}$ Mill, 1999 (1843) p. 47. 
que a impressão mental é ocasionada nos indivíduos devido à experiência para com um objeto, ou mesmo pela composição de um quadro mental ou pela recordação de um sentimento (pesaroso ou alegre). Por exemplo, se alguém vir ou tocou um corpo, ou se um pintor compôs um quadro mental, ou um indivíduo foi alegre ou triste, ele gerou, além da impressão mental, uma idéia que é uma impressão menos vívida, inferior em intensidade, sem a presença de nenhuma causa àquela que provocou a impressão, a idéia é gerada a partir da impressão sem a presença da causa que gerou a impressão mental. Em outros termos, pode-se dizer, também, que um estado de consciência menos intenso foi gerado a partir de um estado de consciência mais intenso, porém semelhante.

A segunda lei mental descrita por Mill é a lei de associação e refere-se ao fato de que quando duas impressões foram experimentadas ou mesmo pensadas, simultaneamente, com freqüência ou em sucessão, então sempre que uma delas voltar à mente a outra tende, também, a ser gerada.

A terceira lei é denominada freqüência de conjunção, sendo que seu significado expressa que a maior intensidade em uma ou duas impressões tornando-se apta para causar umas às outras. Estas são leis de idéias que são remetidas a obras psicológicas, em particular à Análise do Fenômeno da Mente Humana, de James Mill e às obras sobre o Entendimento de Hume em que as principais leis de associação, bem como várias de suas aplicações, são exemplificadas.

A discussão sobre natureza humana será aprofundada no próximo capítulo, quando for traçado o modelo de indivíduo teórico de Mill. Neste capítulo pretende-se fornecer elementos do pensamento e da educação de Mill para fixar o novo modelo de homem a ser estabelecido por Mill relativamente a Bentham e sua nova moralidade, conseqüentemente.

Voltando à questão da comparação entre a fama de seu pai e a de Bentham, John Stuart Mill ressalta que outra razão que tornou a fama de seu pai menor do que a de Bentham reside no fato de continuar sustentando idéias do século XVIII no século XIX não contribuindo nem para as boas nem para as más reações do século XIX que foi importante característica da primeira metade do século dezenove. De acordo com Mill, o século XVIII foi uma importante era de bravos e fortes homens e seu pai esteve entre estes eminentes pensadores. Perto do fim de sua vida foi um dos mais importantes líderes 
dos intelectuais radicais da Inglaterra. Além da importância de assumir posição política marcada em seu país, Mill ressalta que passariam muitos anos antes que os livros de James Mill fossem totalmente superados entre eles estariam o Análise da Mente e o História da Índia no qual Mill teria elaborado uma política bem-sucedida política para a Índia, a exceção seria os Elementos de Economia Política. Outras virtudes de James Mill foram citadas por John Stuart Mill, como seu poder de influenciar outras mentes, qualidade esta que, segundo o autor, seria equiparada apenas a de Harriet Taylor.

No que diz respeito ao exame da filosofia do Sir William Hamilton é possível afirmar que Mill ficou desapontado com as Lectures do autor, publicadas entre 1860 e $1861^{220}$. Mill leu estes escritos, bem como as Notas a Reid e as Discussões Filosóficas; e embora Mill soubesse que tinha muitos pontos de divergência com Hamilton, o admirava pela polêmica que tinha com os trancendentalistas e ponderando entre seus pontos de desacordo e de acordo, chegou a pensar que talvez pudesse ter mais a ganhar do que a perder com a difusão do pensamento deste autor. Entretanto, após uma leitura mais cuidadosa das Lectures e das Dissertations on Reid os pensamentos de Mill foram modificados, os aparentes pontos de acordo entre ambas as filosofias foram desfeitos e a filosofia de Hamilton passou a parecer, então, errônea sob o prisma de Mill.

Após esta minuciosa análise da obra de Hamilton, Mill percebe que a diferença entre as escolas filosóficas do intuicionismo e da experiência e associação não era mais assunto ou tema de mera conjectura abstrata, pois tais escolas seriam a base para inúmeras opiniões práticas. Este era, portanto, o ponto de vista de Mill contrariamente à doutrina de Hamilton, especialmente porque era o ponto de vista de dois representantes de escolas diferentes, a saber: Hamilton o representante da escola intuicionista e Mill o representante da escola da experiência e associação. Desta forma, os escritos de Hamilton foram opostos aos escritos de Mill ${ }^{221}$.

Assim, justifica-se a não abordagem, nesta tese, das influências de Hamilton nos escritos morais de Mill, pois os escritos deste autor mais serviram de negação para Mill do que de influência no sentido positivo da palavra.

\footnotetext{
${ }^{220}$ Ibid (edição Liberty Fund, p. 233).

${ }^{221}$ Ibid, 1873 (edição do liberty fund, p. 235).
} 
Em 1865, Mill foi eleito membro do parlamento, bem como, durante o tempo que esteve no parlamento o autor escreveu o Ensaio sobre Platão publicado na Edinburgh Review e reimpresso no terceiro volume das Dissertações e Discussões. Escreveu ainda a conferência que pronunciou na Universidade de Saint Andrews, cujos estudantes o haviam eleito reitor. Neste discurso o autor expressou muitas de suas idéias a respeito de assuntos clássicos e científicos e acusava o novo método de ensino como o responsável por não conciliar o método de ensino clássico e científico ${ }^{222}$.

Por meio desta breve explanação das influências no pensamento de Mill, baseada principalmente, em uma síntese de suas palavras, expressas na Autobiografia, é possível deduzir que algumas influências foram mais fortes do que outras no que diz respeito ao seu trabalho. Está muito claro que seu pai e sua esposa foram as mais importantes influências pessoais em sua vida, como o próprio autor deixa claro em sua Autobiografia. No entanto, o que se pretendeu, neste trabalho, é considerar os autores que mais influenciaram sua teoria moral para a elaboração de seu modelo de homem e conseqüente formação de seu conceito de moralidade.

De acordo com o que foi dito acima e tendo por base, principalmente o livro Autobiografia, ou em outras palavras, de acordo com uma análise do livro Autobiografia é possível concluir que as principais fontes ou pontos de inflexão nos conhecimentos de Mill foram mais os autores sobre os quais ele escreveu do que aqueles que ele apenas leu, mas não escreveu a respeito. Estes autores foram Bentham, conforme descrito, tal autor mudou sua visão ou em suas palavras; parecia que toda sua formação estava sendo conduzida para que ele se transformasse em um utilitarista, ou seja, quando ele tomou contato com a doutrina de Bentham, parecia que esta resumia e bem ordenava tudo que havia estudado. Como crítica ao utilitarismo depois de sua crise mental (ainda considerando o critério sobre o qual os autores mais importantes para sua obra foram aqueles ele escreveu) considero como suas principais influências, para formação de sua nova doutrina utilitarista, Comte e Coleridge. Poderia ser possível dizer que Aristóteles e Platão (autor sobre o qual ele também escreveu) também constituíram importantes fontes antigas, pois como Mill ressalta, estes autores (especialmente Aristóteles quando se considera que o autor descreve o impacto em suas idéias morais decorrente da leitura da

${ }^{222}$ Ibid, 1873, p. 249. 
Retórica) constituíram importantes pontos de inflexão, quando ele era muito jovem, no que diz respeito ao assunto moral, embora o autor não tenha escrito sobre Aristóteles.

Portanto, este tópico tratará mais profundamente as críticas que Mill formulou relativamente à Bentham à luz dos autores que o influenciaram, conforme foi mostrado ao longo do tópico que acabou de ser explicitado.

2. A concepção de Bentham: a rejeição parcial do utilitarismo de Bentham em relação ao utilitarismo de Mill.

O princípio de utilidade entendido como Bentham o compreendia uma vez lido por Mill gerava unidade aos seus conceitos, após a leitura do Traité de Bentham, antes de sua crise mental. A partir deste momento, foi descrito na sessão anterior, que o autor começou a ter uma filosofia, uma doutrina ${ }^{223}$. Ele tinha uma concepção de mudanças a serem efetuadas na condição da humanidade por meio desta doutrina. $\mathrm{O}$ pensamento de Bentham definiu as aspirações de Mill, conforme descrito. Relembrando o que foi descrito na sessão acima; o Traité de Législation foi o livro que produziu o maior efeito nas idéias de Mill. Lendo este livro após um intervalo de anos, depois de sua crise mental, Mill descobriu para além dos méritos, os defeitos do modo de pensar de Bentham. Em outras palavras, pode ser dito que Mill encontrou algumas falhas no modo de pensar de Bentham, além de seus méritos, deparou-se com muitos argumentos que deveriam ser corrigidos. Entretanto, ainda mantinha a impressão de que possuía um bom material para construir uma filosofia e é por isso que se afirma que apesar das críticas efetuadas ao sistema teórico de Bentham, Mill não deixa de ser um utilitarista.

Os méritos de Bentham e seu modo de pensar marcaram a filosofia de Mill para sempre e o transformou em um utilitarista ${ }^{224}$. É possível dizer que Mill formulou o princípio da utilidade de uma maneira muito explícita e científica no sentido de que este princípio derivaria o valor das regras da moralidade (será minha tese a de que uma vez que as regras morais tornem-se constantes a partir do uso, elas não mais terão um apelo ao primeiro princípio, uma vez que está presente na natureza humana o hábito). $\mathrm{O}$

\footnotetext{
${ }^{223}$ Ibid, 1873 , p. 70.

${ }^{224}$ Mill, Utilitarianism, 1861, p.55.
} 
princípio da utilidade de Mill ainda é o princípio da máxima felicidade, pois ele ressalta que o que importa para os seres humanos é procurar a felicidade, entretanto, o princípio da utilidade é derivado de uma mais complexa natureza humana quando comparada à natureza humana de Bentham. Este último autor, conforme descrito, no primeiro capítulo deste trabalho, assume que seres humanos tendo uma natureza humana baseada principalmente por uma capacidade de efetuar cálculos entre os sentimentos de prazer e dor como as que governam as ações humanas, descreve o princípio da utilidade como aquele que reconhece a sujeição do indivíduo a estes sentimentos e têm o objetivo de colocá-los como fundamento para a construção de um corpo teórico (incluindo no campo moral) que visa a melhor sociedade possível. Dentro deste contexto a explicação do princípio é formulada por Bentham da seguinte forma, como explicada no primeiro capítulo:

\section{"[...] Por princípio da utilidade entende-se aquele princípio que aprova ou desaprova qualquer ação, segundo a tendência que tem a aumentar ou a diminuir a felicidade da pessoa cujo interesse está em jogo[...]".(Bentham, 1789, p.10).}

Apesar de Mill ser considerado um utilitarista o que significa que ele concorda com o fato de que seres humanos possuem uma natureza humana atrelada à busca de prazer e à fuga da dor, esta natureza, assim descrita por este autor, será mais complexa em seu sistema utilitarista porque este indivíduo procura prazeres humanos o que significa dizer prazeres de qualidade superior que não são intercambiáveis por prazeres de animais inferiores. Para que se consiga estes prazeres Mill descreve em sua Autobiografia que os indivíduos deveriam ter em vista outro fim que o próprio prazer (como por exemplo o auto-desenvolvimento por meio do esclarecimento ${ }^{225}$ ). Esta consideração mudará o conceito de princípio de utilidade de Mill, pois considera-se que o princípio de utilidade é diretamente decorrente do conceito de natureza humana que o autor desenvolve (sendo o mesmo procedimento válido para Bentham). Entretanto, não será neste capítulo que as novas características do indivíduo teórico de Mill serão mostradas, o que se tem feito neste capítulo é preparar e descrever o cenário no qual as

${ }^{225}$ Ver Donner Wendy, 1991, p. 119. 
idéias que influenciaram a filosofia de Mill derivam o capítulo terceiro, no qual seu novo homem (comparativamente ao homem de Bentham) será construído e conseqüentemente seu novo utilitarismo.

Desta forma, o próximo passo consiste em mostrar as principais influências teóricas na filosofia de Mill, no que concerne à sua teoria Ética, que se possui fortes evidências. Entende-se aqui por fortes evidências as referentes aos autores sobre os quais Mill escreveu ensaios positivos sobre ética relativos a estes autores, conforme discutido anteriormente. O único ensaio crítico que se considerará aqui será o ensaio de 1838 dirigido a Bentham, por se considerar que estas críticas servem de preparação para que Mill construa um novo utilitarismo em relação a Bentham, embora não deixe de ser um utilitarista.

De acordo com os pensamentos de Mill analisados em sua Autobiografia, Bentham e Coleridge são dois pensadores que pensaram que a filosofia especulativa é em realidade um dos principais assuntos que têm importantes influências nos interesses do homem e nos assuntos da vida e da sociedade. Estes autores foram lidos por poucos filósofos, de acordo com Mill, mas estes poucos autores que os leram disseminaram estas idéias pela sociedade afora. Mill chama Bentham de um filósofo progressivo e Coleridge de um filósofo conservador. A influência de Bentham foi sentida nas mentes de pessoas progressivas, enquanto Coleridge teve mais influência sob pessoas conservadoras, de acordo com Mill. Bentham foi um grande questionador da ordem estabelecida em seu tempo, especialmente no que concerne a assuntos referentes à legislação 226 .

Mill chama Bentham de pai da inovação inglesa, tanto nas doutrinas (utilitarista) e instituições. Ele é considerado o grande subversivo, ou, na linguagem dos filósofos continentais, o grande crítico, pensador de sua época e país. Foi, também, colocado por Mill entre os filósofos negativos, entre aqueles que podem perceber o que é falso, mas não podem perceber o que é verdadeiro ${ }^{227}$. Mill relata um exemplo; Bentham é capaz de detectar falsas leis morais, mas não pode elencar normas de ação, ou seja, seu indivíduo, a partir de sua razão calculadora pode derrubar falsas regras morais, mas não pode construir novas regras em seu lugar, porque seu utilitarismo é vazio de conteúdo,

\footnotetext{
${ }^{226}$ Com respeito a assuntos referentes à propriedade Bentham torna-se mais conservador. Vide Bentham em Principles of Civil Code, 1843 ou Dias, Dissertação de Mestrado, 2007.

${ }^{227}$ Mill, 1838, p.166.
} 
derivado da pobre natureza humana. Em outras palavras, o utilitarismo de Bentham, aponta para a busca do prazer e a fuga da dor, mas não fornece outros subsídios para que este indivíduo preencha de conteúdo o prazer ou a dor e assim construa normas morais.

De acordo com Mill, Bentham era capaz de achar todas as inconsistências e absurdos nas opiniões e instituições de sua época, mas não podia substituir por nada em seu lugar ${ }^{228}$. Então, Mill assume que Bentham possuía muitos méritos por ser capaz de perceber os erros em instituições e denunciá-las, entretanto, Mill ressalta que ele não podia consertá-los, especialmente no que se refere ao ramo do conhecimento ético. Portanto, Mill o chama de filósofo negativo. Mill ressalta que se foi a época de todos os tipos de filosofia céticas (entenda-se cética aqui como uma filosofia que duvida de instituições e outras questões sem resolvê-las por completo, e nisto inclui-se a de Bentham $^{229}$ ). Por exemplo, Mill ressalta que a França teve Voltaire ${ }^{230}$ e sua escola de pensadores negativos, a Inglaterra e a Escócia tiveram David Hume ${ }^{231}$, mentes, que de acordo com Mill, estariam mais voltadas a detectar falhas em provas e desejos de consistência lógica do que filosofias positivas mais destinadas a construir.

É possível afirmar, sob o prisma de Mill, que Bentham subverteu uma geração, ocupou um espaço vazio deixado por Hume, o espaço para crítica aos abusos práticos à legislação. Este era o campo peculiar de Bentham, de acordo com Mill, em seu ensaio de 1838. Ele chamava Bentham de um homem com sensibilidade moral, porque ele conseguia apontar muitas fraudes na lei que deveriam ser corrigidas, de acordo com o princípio da utilidade ${ }^{232}$.

O jeito crítico de ser de Bentham começou, talvez, em Oxford, para onde foi mandado aos quinze anos de idade e foi requerido dele, na admissão, que declarasse sua crença nos trinta e nove artigos ${ }^{233}$. Bentham sentiu que era necessário examinar tais artigos e ao efetuar tal exame este autor apontou os erros dos artigos e declarou as

${ }^{228}$ Mill, 1838, p.166.

${ }^{229}$ É interessante notar que após 1838 Mill fará uma revisão deste artigo, ressaltando que cometeu certos exageros ao apontar Bentham como um filósofo apenas negativo.

${ }^{230}$ Claramente é muito questionável a maneira como Mill enquadra Voltaire como cético.

${ }^{231}$ Novamente é questionável como Hume é enquadrado como cético. Talvez ele poderia ser denominado um cético mitigado.

232 Vide Dias, Dissertação de Mestrado, 2007.

${ }^{233}$ Os trinta e nove artigos da religião foram estabelecidos em 1563 e são afirmações históricas da doutrina anglicana em relação às controvérsias da reforma inglesa; especialmente na relação da doutrina calvinista e práticas católicas romanas da nascente doutrina anglicana da igreja inglesa. 
soluções como sendo errôneas. Nas palavras de Mill: "Ele não foi um grande filósofo, mas um grande reformador na filosofia ${ }^{234}$ [Mill, 1838, p. 168]. Mill diz que Bentham tinha um lugar entre os grandes intelectuais que fizeram o bem para a humanidade, não foi apenas pela doutrina criou, mas também pelo seu modo de chegar a esta doutrina. Tal modo equiparou a um intelectual benfeitor da humanidade. Nas palavras de Mill $^{235}$ :

"Ele introduziu na moral e na política aqueles hábitos de pensamento e modos de investigação, que fizeram destes ramos de investigação, assim como a física tinha sido antes de Bacon, um campo de intermináveis discussões, não levando a nenhum resultado. Não eram suas opiniões, em resumo, mas seu método, que constituíam a novidade do que ele fez; um valor além de todo preço, mesmo se devêssemos rejeitar o todo, assim como inquestionavelmente devemos, amplamente, rejeitar as suas próprias opiniões " [Mill, 1838, p. 168].

Mill, estaria sugerindo, nesta passagem, que boa parte das opiniões de Bentham fossem desprezadas e que apenas seu método de questionamento de afirmações assumidas como verdades fossem mantidas, esta afirmação do ensaio de 1838, conforme o próprio Mill descreve, mais tardiamente, havia sido exagerada, Mill iria manter diversas opiniões de Bentham, inclusive o princípio de utilidade, apenas estava exagerando em seu modo de pensar, para agregar novas idéias ao utilitarismo. Em outros termos, neste aspecto, extremante radical de crítica à Bentham, Mill voltou atrás, pois relata $\mathrm{Na}$ Autobiografia que havia assumido uma posição extremada ao publicar este artigo. Portanto, deve-se assumir que Mill manteria muitas das teses de Bentham como a tese hedonista assinalada no capítulo 2, parágrafo 2 do livro Utilitarismo, embora Mill modificará bastante o modelo de indivíduo teórico de Bentham, conforme ficará claro, no transcorrer deste trabalho.

\footnotetext{
${ }^{234}$ Tradução livre de Mill, 1838, p. 168: "He was not a great philosopher, but he was a great reformer in philosophy”.

${ }^{235}$ Tradução livre de Mill, 1838, p. 168-169 : "He introduced into moral and politics those habits of thought and modes of investigation, which made those departments of inquiry, as physics had been before Bacon, a field of interminable discussion leading to no result. It was not his opinions, in short, but his method, that constituted the novelty and the value of what he did; a value beyond all price, even though we should reject the whole, as we unquestionably must large part, of opinions themselves".
} 
Apenas a título de ilustração, o princípio de utilidade de Bentham assume que temos uma natureza sob o governo de dois senhores soberanos, a saber: o prazer e que é correto, portanto, buscar o prazer (um bem em si) e evitar a dor (um mal em si) a esta tese, pode ser chamada de tese hedonista, tudo deriva seu valor. Enquanto, apesar de continuar sendo um utilitarista e, portanto, também assumir que os homens têm uma natureza atrelada à busca de prazer e fuga da dor, mantendo, desta forma, a tese hedonista, inicial de Bentham, anexa a ela conteúdo, pois assume que não é qualquer prazer que interessa aos seres humanos, conforme se verá no capítulo seguinte, os indivíduos possuem faculdades mais elevadas que uma vez ativadas não se contentam com prazeres de animais de razão inferior, por exemplo.

No parágrafo 2.2 do Utilitarianism (Utilitarismo) Mill aceita como fundamento da moral a utilidade ou o princípio da maior felicidade, ainda assume, como faz Bentham que ações são corretas na medida em que tendem a promover a felicidade e errôneas na medida em que promovem o reverso da felicidade. Ressalta que por felicidade é entendido prazer ou falta de dor e por infelicidade entende-se dor e a privação de prazer. Entretanto, diferentemente de Bentham assume que para dar uma visão clara do padrão moral estabelecido pela teoria, muito mais seria necessário ser dito, isto inclui a idéia ou o conteúdo de dor e prazer e o quanto isto consiste uma questão aberta, além disso nada exclui a idéia de que a natureza humana descrita por Mill é mais complexa do que a de Bentham e é por isso que muito mais pode ser dito acerca da sua moralidade. Torna-se importante notar que na Autobiografia o autor, após sua crise mental deixou claro que estava convencido de que apesar de ter certeza de que a felicidade era a meta a ser traçada na vida, para que esta fosse atingida, ela precisaria ser constituída de diversos componentes. Ou seja, a tese hedonista continuaria na base das ações humanas, embora de modo muito mais complexo, pois o indivíduo teórico de Mill será mais complexo quando comparado ao de Bentham, sendo também seu princípio de utilidade e como decorrência o espaço para a elaboração de regras morais mais complexo. Portanto, pode-se dizer que se está aqui diante de um princípio de utilidade mais complexo que trará espaço para uma ética também mais complexa, conforme se verá. O indivíduo irá para o campo prático dotado de uma série de princípios secundários ou regras morais derivadas do princípio de utilidade. 
No que concerne ao método de Bentham, Mill chama o método deste autor de método de detalhe, no ensaio que escreveu sobre Bentham em 1838. No livro VI do Sistema de Lógica o autor denomina o método de Bentham de geométrico e um número elevado de pensadores que trataram os fatos sociais de acordo com o método geométrico, não admitindo nenhuma modificação da lei do fenômeno social por circunstâncias e repetições capazes de formar novas leis, devem ser deixados fora de consideração, pois cometem grave erro que será tratado posteriormente. Outros autores cometeram erros ainda mais graves quando deduziram conclusões políticas, não de leis da natureza, não de sequiências do fenômeno real, mas de máximas práticas (artes, no sentido antigo). Estes autores são aqueles que assumem um contrato social ou qualquer outra obrigação original prática e a aplica a casos particulares. Entretanto, neste erro fundamental está a tentativa de tratar uma arte, um preceito, como uma ciência e obter, então, uma arte dedutiva.

Como exemplo destes autores estão aqueles que assumem como princípio de sua filosofia política que o governo é fundado, ou baseado no medo, que o medo dos outros é o motivo pelo qual os seres humanos são levados ao estado de sociedade e são conservados nele, sob a interpretação de Mill. Algumas das pesquisas científicas em política (como a de Hobbes) adotaram esta proposição ${ }^{236}$ como fundamento de suas teorias e erigiram uma completa filosofia política em cima desta proposição. Para tratar do assunto político, de acordo com Mill, Hobbes adicionou um outro elemento além do medo a fim de que os indivíduos saíssem do estado de natureza e entrassem no estado civil, a saber: o contrato original. Mill define o termo contrato original como um sofisma duplo (raciocínio capcioso feito com a intenção de enganar), porque, primeiro passa da ficção ao fato e segundo porque assume o princípio prático ou preceito como a base de uma teoria. Toda regra de conduta deve estar fundada, baseada, na teoria do assunto e a teoria não pode estar fundada nestas regras de conduta (arte). Mais uma vez Mill reforça a importância de fundamentar uma arte sobre uma ciência e não o contrário.

Mill também coloca a filosofia do interesse da escola de Bentham na classe das escolas que utilizam o método geométrico, mas que cometem erros não por

\footnotetext{
${ }^{236}$ Afirma Mill em A Lógica das Ciências Morais, Mill, 1999, p. 87. Este trabalho não concorda com a afirmação de Mill de que Hobbes fundamenta suas afirmações em um preceito, a saber: o contrato original, pois este autor para atingir a idéia de contrato original possui uma série de conceitos anteriores (como a igualdade entre os homens, a competição, etc axiomas característicos de uma ciência que embasa uma arte em um modelo geométrico).
} 
considerar a ciência fundada na arte, mas por tratar complexo fenômeno social de maneira demasiado resumida, abstrata e distante dos fatos.

$\mathrm{O}$ autor ressalta que Bentham sabia que as regras de conduta devem seguir e não preceder as leis da natureza humana e que as leis da natureza, não as regras de conduta devem ser o campo de aplicação do método dedutivo.

Alguns filósofos, especialmente Bentham, fundaram sua teoria geral do governo em uma compreensiva premissa, a saber: aquela em que as ações humanas são sempre determinadas pelos seus interesses. Bentham deu o nome de interesse a tudo o que uma pessoa gosta, a proposição deve ser entendida como significando que as ações dos homens são sempre determinadas por seus desejos.

Estas proposições, sendo compreendidas neste sentido, entretanto, não fariam com que a teoria conduzisse a nenhuma das consequiências que estes pensadores atingiram, pois seus pensamentos políticos devem ser entendidos como significando o que é comumente denominado interesse privado. Esta proposição não é universalmente verdadeira, de acordo com Mill, por dois motivos, a saber: a) primeiro porque os seres humanos não são governados, em todas as suas ações pelos seus interesses privados e b) porque em política, os governantes não estão interessados na conduta de pessoas individuais, mas na conduta de uma série de pessoas. Então a assertiva deveria ser limitada ao seguinte: qualquer sucessão de pessoas ou maioria de qualquer corpo de pessoas será governada, no todo de sua conduta, por interesses pessoais. Ou seja, até aqui Mill ajusta a teoria de Bentham.

É possível dizer que Mill assume que a teoria vai adiante em inferir corretamente que as ações da humanidade são determinadas, principalmente, pelos interesses próprios e os únicos motivos para fazer governadores governarem de acordo com os interesses do governado são aqueles que estejam de acordo com os interesses privados. À esta segunda proposição é acrescentada uma terceira que é aquela que diz que nenhum dos legisladores possui seus interesses egoístas idênticos aos interesses dos governados a não ser que seus interesses dependam da vontade dos governados. Em outras palavras, que o desejo de manter ou o medo de perder seu poder é o único motivo em que se pode confiar para produzir, da parte dos legisladores, um tipo de conduta de acordo com o interesse geral. 
Ter-se-ia, então, um teorema fundamental de ciência política constituído por três silogismos e dependente de duas premissas gerais, no qual um efeito qualquer seria considerado como determinado apenas por uma causa, não por um conjunto de causas. De acordo com Mill, é possível afirmar que nesta única causa gerando os efeitos reside o problema, pois uma causa apenas, sem considerar a complexidade do fenômeno social, não é capaz de explicar este fenômeno. Na primeira premissa é assumido que as ações do legislador são determinadas apenas pelo interesse próprio, na outra é assumido que o senso de identidade do interesse com o governado é produzido por interesse de manter-se no poder. Mill argumenta que nenhuma destas proposições constitui verdades. A última é extremamente afastada da verdade ${ }^{237}$.

Não é verdade que as ações mesmo da média dos legisladores são totalmente, ou aproximadamente todas, determinadas por seus interesses pessoais. Mill não quer substituir o interesse pessoal por senso de dever, ou sentimentos de filantropia, motivos nos quais, o autor diz que é arriscado confiar, embora eles influenciem quase todos os legisladores em algum grau e alguns legisladores em um amplo grau. Apesar de não ser esta a objeção de Mill, ele insiste, apenas, no que é verdade para todos os legisladores, a saber: que o caráter e o curso de suas ações são amplamente influenciados (independentemente do cálculo pessoal ou interesse próprio) por sentimentos habituais ${ }^{238}$ que são os modos gerais de pensar e agir, que prevalecem em toda parte da comunidade, da qual eles são membros, bem como por sentimentos, hábitos e modos de pensar que caracterizam uma classe particular naquela comunidade a qual pertencem. Sendo que ninguém entenderá ou será capaz de decifrar os modos de agir dos indivíduos, em particular dos legisladores, que não leve em conta estas considerações.

Os homens do governo são muito influenciados pelas máximas e tradições que descendem de seus predecessores. Tais máximas e tradições têm sido conhecidas por reter uma ascendência durante longos períodos, mesmo em oposição aos interesses privados dos legisladores. Mill ressalta que não apenas os interesses pessoais dos legisladores são motivos de suas ações, mas a tradição e o hábito também determinam seus atos (é tese deste trabalho que para Mill o hábito constitui parte da natureza

\footnotetext{
${ }^{237}$ Mill em A Lógica das Ciências Morais, Mill, 1999, p. 89.

${ }^{238}$ Ibid. Grifo nosso.
} 
humana), tanto dos legisladores quanto dos indivíduos em geral (pois o indivíduo é o mesmo seja no governo ou fora dele), por isso o método geométrico ou abstrato não pode ser levado em conta para se fazer ciência social, pois causas contrárias ou outras causas (que não apenas uma) devem ser levadas em conta para que se entenda o fenômeno social.

Mill destaca, entretanto, que o interesse privado dos legisladores e da classe legisladora é uma força muito poderosa, constantemente em ação, e desempenhando a mais importante influência sobre seus atos (ou seja, Mill continua dizendo que a mais importante parte da influência das ações dos indivíduos e legisladores está em seu interesse pessoal), contudo, há, também, em suas ações, algo que não é suficientemente explicado pelo interesse pessoal. Os fatos particulares que constituem a bondade ou maldade de seu governo são, em alguma medida não pequena, influenciados pelas circunstâncias que agem sobre eles que não podem ser incluídas no termo interesse próprio.

Com respeito à outra proposição denominada interesse de manter-se no poder que seria a única causa capaz de produzir nos legisladores um senso de identificação do interesse próprio com a comunidade, Mill ressalta ser esta proposição ainda menos admissível como uma verdade universal. Em muitos casos, os governos de fato possuem uma identificação com aquilo que o povo pensa.

A partir desta breve análise e crítica de teorias do governo que são ou fundadas sobre um contrato original (uma arte, um preceito fundado sobre uma ciência, quando deveria ser o oposto) ou utilizam um método errôneo (o geométrico) para a construção da ciência que deve fundamentar a arte (os preceitos em ciência política), Mill ressalta que quer deixar claro que preceitos não podem substituir a ciência que embase a arte e que é necessário desconsiderar o método geométrico, por não considerar causas contrárias ou mais de uma causa capaz de explicar a totalidade de um fenômeno, resultando em amplo erro na tentativa desta explicação.

Embora Mill formule esta crítica a Bentham, o autor deixa claro que o erro de Bentham seria mais de forma do que de substância porque as ações dos legisladores seriam, em sua maior parte, influenciadas pelos interesses próprios e assim, supervisões constitucionais seriam requeridas. Da mesma forma, as responsabilidades para com os 
governados (obrigações legais) constituem um importante meio para criar um sentimento de interesse de identidade nos casos onde os sentimentos não foram ocasionados de outra forma, como por exemplo, através da educação.

O grande problema de forma destas teorias está no fato de que consideraram as poucas premissas de suas teorias como incluindo tudo que é requerido para explicar o fenômeno social ou para determinar as formas de governo e medidas de legislação e administração.

Os autores deveriam ter aplicado e de fato aplicaram seus princípios com inúmeras compensações. Contudo, de acordo com Mill, não são compensações que são requeridas, pois é anti-filosófico construir uma ciência que explique poucas funções pelas quais o fenômeno é determinado e deixe o restante à rotina da prática ou à sagacidade da conjectura. Ao fazer ciência é necessário que seja incluso o máximo de todas as causas no escopo da ciência, pois tem-se a tendência a dar atenção desproporcional às causas que a teoria leva em conta, enquanto subestima-se o resto, e, provavelmente deprecia-se sua importância ${ }^{239}$.

As deduções deveriam ocorrer a partir do todo e não de uma pequena parte das leis de natureza que dizem respeito, como ocorre na teoria de Bentham. O fenômeno da sociedade não depende de alguma causa ou lei da natureza humana, sem consideração de modificações de outras causas. A totalidade das qualidades da natureza humana submetida a circunstâncias forma o caráter de um indivíduo e levam a determinadas ações, sendo que estas ações só podem ser explicadas pela elucidação da totalidade das causas que formam um caráter.

A teoria que não considera a modificação e multiplicidade de causas como influenciando o indivíduo é denominado método geométrico de filosofar em ciência social. Portanto, o método geométrico, utilizado por Bentham, para explicar o fenômeno social, a ciência social está fadado ao fracasso, por não incluir todas as causas relevantes que explicam a natureza humana e por não levar em conta as circunstâncias que o $\operatorname{afeta}^{240}$. Ou seja, resta deixar claro que o problema deste método dedutivo refere-se ao

\footnotetext{
${ }^{239}$ Mill em A Lógica das Ciências Morais, Mill, 1999, p. 91.

${ }^{240}$ No próximo capítulo restará claro que Mill passará ao método verdadeiro que procede realmente dedutivamente, mas pela dedução de várias e não apenas de algumas premissas, considerando cada efeito como um resultado agregado de muitas causas, operando algumas vezes por meio das mesmas leis mentais,
} 
fato de que Bentham deduz princípios por meio de poucas premissas que não abarcam a totalidade das causas do fenômeno que influenciam a ação humana.

A descrição acima de como se dá o método errôneo em ciências sociais refere-se ao livro VI do sistema de Lógica de Mill. No que concerne ao ensaio de 1838, é possível ressaltar que há elementos a serem levados em conta no método de Bentham quando se trata de nomear seu método como o método do detalhe, como o método de tratar o todo através da separação deste em partes, tratando as classes e generalidades através de sua explicação a partir de seus componentes. Desta forma, Bentham realiza elaboradas demonstrações para verdades já adquiridas; o assassino, os incendiários, o assaltante praticam ações más, entretanto o autor não toma estas afirmações como verdades sem prova, ele prova tais questões com o maior grau de precisão possível.

Seu método pode ser aproveitado não formalmente, por considerar poucas premissas para explicar um fenômeno (neste sentido, Mill nomeia o método de Bentham como geométrico e o considera inadequado como base para as ciências sociais), mas porque pressupõe que a mente humana não é capaz de entender o todo até que tenha catalogado as partes da qual o todo é feito. As abstrações não são consideradas realidades per se, mas modos de expressar fatos e o único modo de lidar com estas abstrações é traçar um caminho de volta (destas abstrações) para os fatos (não importa se estes fatos sejam fatos da consciência ou fatos da experiência) ${ }^{241}$. Portanto, tanto Mill quanto a Dissertação de mestrado que defendi em 2007 concordam que quando Bentham trata do tema moral ele sempre requer razões para sustentar determinada regra moral, que devem estar, em todos os casos de acordo com o princípio da utilidade.

Bentham sempre requereu mais do que opinião e sempre deu razões para sustentar uma opinião, de acordo com o princípio da utilidade. Mill descreve em seu artigo de 1838, que sempre que o autor achasse uma frase usada como um argumento pró ou contra alguma coisa ele insistiria em seu conteúdo, em razões para sustentar tais argumentos. Mill cita Bentham, em seu ensaio de 1838, na seguinte passagem: "instrumento de evitar o apeloa a quaisquer padrões externos e para impedir o leitor de aceitar o sentimento e a opinião do autor como uma razão, como se fosse suficiente, por

às vezes por meio de causas mentais diferentes ou leis da natureza humana, para entender o método mais adequado em ciências sociais e aquele que embasa a moral, por sua vez.

${ }^{241}$ Mill, 1838, p. 169. 
ela mesma" ${ }^{242}$. Mill ressalta que esta era uma demonstração de fraqueza ${ }^{243}$ e força ${ }^{244}$ no modo de filosofar de Bentham.

Em suma, esta segunda compreensão do método de Bentham consiste em nunca raciocinar sobre a totalidade de algo até que ela tenha sido resolvida em partes, nem sobre abstrações até que elas tenham sido traduzidas em realidades, é por isso que ele é um grande reformador do ramo moral e político ${ }^{245}$.

Mill afirma, novamente, em seu artigo que as generalidades de sua filosofia tinham nada ou pouco de novidade. $O$ autor afirma que estas idéias poderiam ser encontradas em Helvetius e Reid. Afirma ainda que estas idéias não eram novas, nem mesmo no tempo de Epicuro, mas haviam sido formuladas anteriormente. Estas, entretanto, são apenas afirmações do ensaio de 1838, que o próprio autor desconsiderará mais adiante em sua carreira, pois voltará a se aproximar de várias das opiniões de Bentham, embora acrescente muitas considerações as deste último autor.

O que poderia ser considerado novo (neste momento), seria, então, a aplicação de seu método, no segundo sentido do termo. Isto sim consistiria em algo desconhecido para os seguidores de Epicuro, assim como para quaisquer outras escolas. Eles nunca desmontam uma questão em partes e depois juntam o assunto em um ponto definido. De acordo com Mill, Bentham certamente não aprendeu este método destes autores mais antigos. Portanto, Mill reconhece que ele tenha introduzido precisão de pensamento à filosofia moral e política. Ao invés de tomar suas opiniões por intuição, ou raciocinar a partir das premissas adotadas em uma mera visão vaga, os filósofos, a partir de Bentham, seriam forçados a entender um ao outro, a desmembrar as generalidades das proposições e colocar um assunto preciso em cada disputa. Segundo Mill, isto seria nada menos do que uma revolução no campo da filosofia prática.

Mill ressalta que o método de Bentham é seguro por um tipo de compreensão, mas não por outro. Bentham inicia colocando diante dele o todo do campo de pesquisa ao qual a questão particular pertence e divide este campo de pesquisa até que

\footnotetext{
${ }^{242}$ Tradução livre de Mill, 1838, p.170: “contrivance for avoiding the obligation of appealing to any external standard, and for prevailing upon the reader to accept of the author's sentiment and opinion as a reason, and that a sufficient one, for itself".

${ }^{243}$ Fraqueza porque não se refere à história da filosofia.

${ }^{244}$ Força porque sempre exigia razões que não fossem mero senso comum para embasar um argumento.

${ }^{245}$ Ibid, 1838, p. 171.
} 
chega à questão que está procurando e então rejeitando sucessivamente tudo que não diz respeito à questão, ele gradualmente trabalha a definiçãa da questão. Este pode ser chamado o método exaustivo de Bentham. Mill conclui que não existe, provavelmente, nenhum filósofo que possui tão poucas inconsistências como Bentham. Ele diz que a mente de Bentham é eminentemente sintética. A seguir uma citação de Mill sobre Bentham no ensaio de 1838 que confirma o que foi dito [Mill, 1838, p. 173]: "He begins all his enquires by supposing nothing to be known on the subject, and reconstructs all philosophy from the beginning, without reference to the opinions of his predecessors". É por isso que ele é sintético, porque síntese produz conhecimento ${ }^{246}$.

Neste mesmo ensaio de 1838 Mill argumenta que para que se faça uma filosofia de um assunto torna-se necessário que se conheça as propriedades do assunto, para a ética e filosofia política, é necessário que se conheça as propriedades do homem e conhecer a posição do homem no mundo também é uma condição necessária ${ }^{247}$. Assim, justifica-se mais uma vez a necessidade de desenvolver-se o próximo capítulo, de realizar a construção do modelo de homem de Mill, a partir de seus escritos, principalmente a partir dos livros Utilitarismo e Sistema de Lógica e estas influências teóricas que estão sendo tratadas aqui, conforme o autor dá indícios através da Autobiografia e dos ensaios que escreveu.

Mill afirma explicitamente, que no campo da ética e da política é imperativo que se conheça todas as características da natureza humana, pois se alguma delas for deixada de lado é possível que se falhe nas conclusões e mais ou menos em suas aplicações $^{248}$.

Natureza humana e a vida humana são assuntos amplos, de acordo com Mill. As qualificações para o sucesso em entender-se as vidas humanas serão proporcionais à duas coisas: ao grau no qual sua própria natureza e circunstâncias fornecem a ele com uma correta e completa imagem da natureza do homem e de suas circunstâncias e sua capacidade de derivar compreensão do que foi dito por outros filósofos. No que diz respeito a estes dois aspectos é possível ressaltar que Bentham falhou. No que concerne a derivar compreensão da mente de outros, Mill ressalta que

\footnotetext{
${ }^{246}$ Ibid, 1838, p. 173.

${ }^{247}$ Ibid, 1838, p. 173.

${ }^{248}$ Ibid, 1838, p. 173.
} 
Bentham falhou, pois apresentava poucos traços de conhecimento acurado de escolas de pensamento e muitas provas de que tais filósofos não poderiam ensiná-lo nada de interessante. Mill acusa Bentham de não admirar Platão ou Aristóteles, pois ambos não estavam fundados no reconhecimento da utilidade como padrão moral, mas antes em

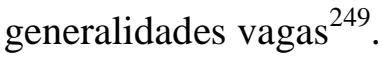

Nas palavras de Mill $^{250}$ :

"Ele não se importava, ou antes a natureza de sua mente prevenia de ocorrer a ele outras generalidades. Estas generalidades continham o todo não analisado da experiência do gênero humano”[Mill, 1838, p. 175].

É possível observar, a partir desta passagem, uma clara crítica da concepção de natureza humana do indivíduo teórico de Bentham, de acordo com Mill. De acordo com este autor, Bentham não tinha conhecimento suficiente de outros autores para construir uma substancial e porque não dizer uma acurada natureza humana.

Desta forma, Mill afirma que a determinação de Bentham ao criar uma filosofia, e ao ignorar a filosofia de outros, consituía sua primeira desqualificação como filósofo $^{251}$. Sua segunda desqualificação como filósofo era a imperfeição de sua própria mente como um representante de uma natureza humana universal. Quanto à maioria dos mais naturais e fortes sentimentos da natureza humana, seria possível afirmar que Bentham não possuía nenhuma simpatia e a faculdade pela qual uma mente entende outra mente diferente dela mesma e se lança nos sentimentos desta distinta mente era negada a ele por sua deficiência de imaginação, de acordo com Mill.

Bentham falhava quando o assunto era imaginação, sob o prisma de Mill. Quando o assunto era cultura poética, sendo necessário o uso da imaginação, Bentham falhava, também, totalmente. O poder pelo qual um autor entra na mente de outro constitui o poeta, por estes limites o conhecimento da natureza humana de Bentham é traçado, pois Bentham é um empirista e como empirista ele também falha, pois possui

\footnotetext{
${ }^{249}$ Ibid, 1838, p. 174.

${ }^{250}$ Tradução livre de, Mill, 1838, p. 174: "he did not care, or rather the nature of his mind prevented it from occurring to them, that these generalities contained the whole unanalyzed experience of the human race”.

${ }^{251}$ Ibid, 1838, p. 175
} 
pouco conhecimento sobre a natureza humana, uma vez que leva em conta poucos aspectos desta natureza.

Mill argumenta que Bentham não possuía experiência interna, e experiência externa $^{252}$ necessária para conhecer a natureza humana. Mill afirma que Bentham não podia conhecer os componentes desta natureza, porque ele mesmo não tinha problemas pessoais, sentimentos inconstantes na vida; isto explicaria porque ele nunca sentiu uma chaga ou a exaustão de um peso. Mill argumenta que seria necessário que ele sentisse estes sentimentos para que fosse transformado em um gênio como Goethe ou Byron. Quanto de natureza humana havia em Bentham? Ele não conhecia e nunca tornou viva as inconscientes influências que poderiam agir sobre ele e conseqüentemente sobre seus semelhantes. Sabendo tão pouco a respeito dos sentimentos humanos, pode-se afirmar que ele sabia menos ainda sobre as influências nas quais tais sentimentos são formados. Portanto, ele possuía uma concepção limitada da concepção de conduta humana e uma concepção limitada do que era uma conduta humana ou de quais seriam as influências sobre ela.

Portanto, interpreta-se que a conclusão de Mill é a de que este autor não poderia formar uma concepção precisa de natureza humana simplesmente porque ele não a conhecia nem por meios internos (i.e os meios que transformam o autor em um gênio, ou seja possuindo esta mesma natureza, nem por experiência externa, porque ele não conhecia muito bem a história da filosofia e história mesma e não possuía um método adequado para fazer ciência do homem, quando entende-se que ele se utilizava do método geométrico para fazer ciência social). Por estas razões, Mill afirma que Bentham era um homem importante para filosofia quando se trata de um aspecto de seu método (o método do detalhe, ou da análise, conforme explanado anteriormente, não tomar nada como certo, não explicar o todo sem antes quebrar este todo em partes e entendê-las), era importante também porque fundava o princípio de utilidade e pode-se dizer que este autor também era notável por suas deficiências (negando a imaginação e sua impossibilidade de descrever uma própria natureza humana complexa). Bentham estava a frente de quase qualquer filósofo, por traçar a partir de suas premissas conclusões não apenas corretas, mas suficientemente precisas e específicas para serem práticas, mas cuja concepção de

${ }^{252}$ Ibid, 1838 , p. 176. 
natureza humana e de vida forneceram a ele um insuficiente estoque de premissas. Em outras palavras, apesar da precisão de Bentham ao traçar conclusões a partir de suas premissas, o problema estava justamente em suas premissas, concepções insuficientes sobre a natureza humana (apenas o auto-interesse não pode explicar a natureza humana método geométrico).

Mill denomina a filosofia de Bentham de meias verdades, entretanto, seus dons em transformar suas conseqüências em aplicações práticas (com o uso de sua lógica) é de um mérito muito próprio a Bentham que deveria ser reconhecido pela posteridade. Mill afirma que as conclusões práticas de Bentham são errôneas, não porque as considerações que ele sustenta não são racionais e válidas por elas mesmas, mas porque existem princípios tão importantes sobre a natureza humana quanto os por ele elencados que ele não percebe e acaba por afastar ${ }^{253}$.

A parte ruim de seu trabalho é resultado da negação de tudo que ele não consegue enxergar, da negação de todas as verdades de todas as causas importantes para explicar o homem, menos aquelas que ele reconhece. As verdades, que não são as de Bentham, as quais sua filosofia não leva em conta, são muitas e importantes, mas seu não reconhecimento delas não as coloca fora da existência. Rejeitar essa verdades seria a mesma coisa do que incorrer em erro ${ }^{254}$. Os pensamentos de Mill sobre construir uma verdade são os seguintes [Mill, 1838, p. 177] "Nenhuma verdade é possível exceto pela combinação de todas as verdades fracionárias" ${ }^{255}$.

O que é a teoria da vida para Bentham? O homem é concebido por Bentham como sendo suscetível de prazeres e dores (conforme afirmado anteriormente), e governado em toda sua conduta por modificações de seu interesse-próprio e as paixões comumente classificadas como egoístas, parcialmente por simpatias ou ocasionalmente por antipatias, junto aos outros. Nesta definição a concepção de natureza humana se encerra para Bentham ${ }^{256}$. Ele não exclui a religião e a sanção moral. Entretanto, o todo

\footnotetext{
${ }^{253}$ Ibid, 1838, p. 177.

254 Ibid.

${ }^{255}$ Tradução livre de Mill, 1838, p. 177: “No whole truth is possible but by combining the points of view of all the fractional truths".

${ }^{256}$ Bentham, 1817, p.211-212.
} 
dos princípios que geram uma ação ou que a impedem, que sejam neste ou em outro mundo são o amor- próprio ou aversão em relação a outros indivíduos ${ }^{257}$.

De acordo com Mill, Bentham nunca abre uma possiblidade para que os homens sejam capazes de perseguirem a perfeição individual, a perfeição de caráter como um fim. Em outras palavras, a capacidade de auto-desenvolvimento ou de melhorar conforme o tempo passa não é uma característica do indivíduo do Bentham, ao menos de acordo com a leitura de Mill ${ }^{258}$.

Mill descreve que nos trabalhos de Bentham existe a falta de uma palavra que é chamada de consciência e esta palavra é ligada à expressão retidão moral, dever moral, mas em sua Table of Springs of Actions esta palavra está entre o sinônimo amor pela reputação. A noção de auto-respeito, a idéia de criaturas semelhantes e de dever moral ocorre raramente apenas para chamar o sentimento de interesse-próprio.

Não é o desejo de perfeição dos seres humanos, ou o sentimento de uma consciência acusatória ou aprobatória que Mill acusa Bentham de negligenciar, mas o reconhecimento de que não existe nenhum outro ideal ou finalidade além do próprio interesse individual em sua teoria. Mill afirma que o senso de honra e de dignidade pessoal $^{259}$ que o sentimento de exaltação pessoal e degradação que age independentemente da opinião dos outros, que o amor à beleza, que a paixão do artista, que o amor pela ordem, o amor pela harmonia, o amor pela consistência em todas as coisas e conformidade a seus fins e o amor pela paz, poderosos motivos de ação, são pensamentos que não tiveram um espaço na Table of Springs of Actions de Bentham. $\mathrm{O}$ homem, um dos seres mais complexos, nas palavras de Mill, é um ser muito simples aos olhos de Bentham.

Bentham, acostumado a manter diante de seus olhos a felicidade da humanidade, como o único fim desejável em si, confundiu todos os sentimentos desinteressantes que ele achou nele mesmo, com o desejo geral de felicidade ${ }^{260}$. Bentham confundiu o amor à virtude com o medo do inferno, para Mill estes sentimentos estavam completamente separados. O amor pela virtude e o medo do inferno, definitivamente não

\footnotetext{
${ }^{257}$ Mill, 1838, p. 177.

${ }^{258}$ Ibid.

${ }^{259}$ Mill, 1838, p. 178.

${ }^{260}$ Ibid.
} 
são a mesma coisa, Bentham não poderia ver a distinção entre ambos, enquanto esta distinção é clara e distinta para muitos. Seus partidários seguiram Bentham em sua doutrina da utilidade, e em sua rejeição de um senso moral, praticando um teste do certo e do errado no campo moral, questionando a moral dos costumes, derivada de seu modelo de homem com uma racionalidade calculadora, sem, contudo, construir uma moralidade no lugar. Nas palavras de Mill ${ }^{261}$ :

\begin{abstract}
"mas enquanto isto como tal, eles têm, com Hartley, adquirido isto como um fato da natureza humana. A questão que surge é o que é um fato na natureza humana? Apenas rejeitar o dever moral, porque nós somos, por natureza autointeressados". [Mill, 1838, p. 179].
\end{abstract}

Mill descreve que a idéia de Bentham em relação ao mundo é de um conjunto de pessoas perseguindo cada um em separado seu interesse, seu próprio prazer e evitando a dor e a prevenção de que os membros de uma comunidade gerem dor ou a esperança de que provoquem prazeres uns aos outros. A dor e o prazer para Bentham devem provir de três principais fontes, a saber: a) política, b) religiosa e c) moral, operando por meio da sanção física ${ }^{262}$.

Continuando sua crítica sobre Bentham, Mill questiona o quão longe esta visão de natureza humana atrapalha o campo ético e o quanto esta visão contribui para a filosofia social e política. Em outras palavras a questão é: o que esta visão faz pelos indivíduos e pela sociedade?

De acordo com Mill, esta visão não traz contribuições para conduta individual, além de prescrever alguns dos mais óbvios ditados do mundo como a prudência (no sentido de ditar que os inidivíduos sigam seus próprios interesses). Mill ressalta que o sistema de Bentham não pretende ajudar indivíduos na formação de seus

\footnotetext{
${ }^{261}$ Tradução livre de: "but while repudiating it as such, they have, with Hartley, acknowledge it as a fact in human nature". The question that arises is what is a fact in human nature? Just reject the moral duty, because we are, by nature self-interested". [Mill, 1838, p. 179].

${ }^{262}$ Mill, 1838, p. 180.
} 
próprios caracteres. $\mathrm{O}$ sistema de Bentham ${ }^{263}$ não considera nem a metade do número de sentimentos mentais ${ }^{264}$ dos quais os seres humanos são capazes de sentir.

Como uma resposta a esta crítica, Mill afirma que o campo moral é constituído de duas partes: uma delas é a educação do próprio indivíduo, de suas afecções e de suas vontades. De acordo com Mill, este ramo do estudo moral está em branco no sistema de Bentham. Enquanto o outro ramo, a regulação das ações para com outros não faz sentido ser discutida sem um sistema moral próprio de auto-educação dos sentimentos dos seres-humanos. As afecções humanas e os desejos não foram compreendidos por Bentham, de acordo com Mill, o que significa que ele não pode construir um próprio campo moral. Algumas questões como relações sexuais, ou aquelas relacionadas à família em geral, ou qualquer outra questão com conexão simpática de um cunho íntimo social encontra-se inexplicada no sistema de Bentham. O campo ético destas questões dependem de considerações que Bentham nunca levou em conta, ou levou em conta em patamares insuficientes.

$\mathrm{O}$ assunto de Bentham repousa mais sobre questões de jurisprudência do que sobre questões éticas. Nada sobre o último assunto foi publicado, exceto a Deontologia. Ele não possuía um profundo conhecimento ${ }^{265}$ do coração humano, de acordo com Mill. Levando estas considerações em conta, as questões de Mill são: como poderia a opinião de Bentham ser válida sobre a formação de um caráter nacional? Como poderia ele, cuja mente continha tão poucos e pobres tipos de caracteres individuais, tirar tantas conclusões a partir de altas generalizações? Tudo que Bentham pode fazer com seu sistema é indicar meios através dos quais, em qualquer estado nacional, os interesses materiais da sociedade podem ser protegidos (o negócio de Bentham é proteger os interesses materiais de uma dada sociedade), de acordo com Mill, mas não construir um espaço para uma ética.

No ensaio de 1838 sobre Bentham, Mill admite que Bentham só pode ensinar meios de organizar e regular as partes que tratam de negócios dos arranjos sociais. Sua falta de imaginação, pouca experiência com sentimentos humanos (sendo ele mesmo um pobre exemplar do gênero humano), pouco conhecimento da história da

\footnotetext{
${ }^{263}$ Mill, 1838, p. 180.

${ }^{264}$ Há que se considerar, conforme relatado anteriormente, que todos os sentimentos para Mill são mentais.

${ }^{265}$ Mill, 1838, p. 183.
} 
filosofia e ignorância da conexão de sentimentos de uns para com os outros fez com que este autor fosse incapaz de construir um campo para a ética ${ }^{266}$. É evidente que neste ensaio de 1838 Mill efetua duras críticas a Bentham, mas John Mill não deixa de sustentar no transcorrer de sua vida e de outras obras suas, como o Utilitarismo traços utilitaristas como o fato de que o fim que todos buscam é a felicidade e que as ações corretas são aquelas que levam à busca de prazer e as errôneas são aquelas que vão de encontro à geração da dor, ou seja apesar de todas estas críticas à teoria moral de Benham, a tese principal - hedonista ${ }^{267}$ - se mantém. A diferença de Mill para Bentham está justamente no fato de que mais elementos são necessários para explicar a teoria ética de $\mathrm{Mill}^{268}$. Isto não impede, contudo, que o resultado, seja a obtenção de prazer e fuga da dor como sendo as únicas coisas das quais se derivam o valor das outras.

Desta forma, Mill ressalta que o campo de Bentham era como o espaço entre duas linhas paralelas. Estreita em uma direção, em outra alcançaria o infinito. As especulações de Bentham são mais relativas à lei e naquela área ele alcançou seus maiores triunfos ${ }^{269}$. Bentham encontrou a filosofia da lei em caos e a deixou como uma ciência. Antes de Bentham a base da lei inglesa era baseada no princípio da simpatia, julgavam-se as pessoas e puniam-se tais indivíduos porque os juízes não gostavam de seus réus, após a formulação do princípio da utilidade, passou a existir um princípio positivo para julgamento de todas as pessoas afetadas por um ato. Um balanço entre prazer e dor, benefício e custo de uma determinada ação para a sociedade passou a existir.

Além disso, o método peculiar, o método do detalhe de Bentham capaz de mostrar que as leis eram feitas de um modo errôneo (por exemplo guiadas pelo princípio de simpatia) e depois que deveriam ser reescritas à luz do princípio de utilidade levava à modificações na legislação até então impensadas. Mill relata que nenhum homem estava tão qualificado a apontar tais mudanças quanto Bentham. Segundo Mill, Bentham clareou a confusão e a vagueza anexadas à idéia de lei através do princípio da utilidade e da proposta de codificação. A doutrina da codificação declara que não importa quais sejam

\footnotetext{
${ }^{266}$ Mill, 1838, 181.

${ }^{267}$ Ver Mill em Utilitarianism, 2.2, p. 55.

${ }^{268}$ No Sistema de Lógica Mill ressalta que, assim como a Lei de Gravitação, as Ciências Sociais constitui a explicação a partir de várias causas em várias direções.

${ }^{269}$ Mill, 1838, p.182.
} 
as leis, elas devem ser sistematicamente organizadas (em por exemplo, um código civil e consitucional). Ele possuía as respostas para ataques contra as codificações, mas estas respostas esbarraram em suas limitações que são estabelecidas a partir de suas especulações sobre a natureza humana ${ }^{270}$, porque suas explicações sobre natureza humana são muito limitadas para levar a uma codificação de todas as nações, para explicar as diversas causas que geram o caráter de indivíduos diversos, conforme modificam-se o caráter nacional e consequentemente as ações dos indivíduos.

Bentham era pouco acostumado a prestar atenção às diferenças entre instituições e nações, de acordo com Mill. Entretanto, Mill ressalta que erros de tentar efetuar uma codificação sem notar a diferença entre nações não apagam sua enorme importância na formulação de uma teoria do governo radical.

No fato de dar mais poder à maioria do povo através da democracia reside, exatamente, o que se denomina de radicalismo, isto constitui uma reação contra os governos aristocráticos. Muitos homens devotaram suas vidas a este movimento e muitos deram suporte a Bentham. Entretanto, Mill realiza um contraponto ao governo da maioria efetuando às seguintes questões: onde há a identidade de posição ${ }^{271}$ haverá também identidade de parcialidades, de paixões e preconceitos? E para dar para qualquer conjunto de pessoas que sustentem a identidade de parcialidade, paixões e preconceitos o poder absoluto sem um contrapeso destas parcialidades pode-se dizer que é um caminho para render-se a estas graves imperfeições. Nas palavras de Mill:

\footnotetext{
"Deve haver, nós sabemos, algum tipo de poder supremo na sociedade; e que a maioria deveria ser aquele poder, está no todo certo, não tanto como nisto mesmo, mas como sendo menos injusto do que qualquer outro fundamento no qual o assunto pode ser colocado. Entretanto, é necessário que as instituições da sociedade deveriam preparar-se para manter, de uma forma ou outra, como um corretivo às visões parciais e uma defesa para a liberdade de pensamento e da individualidade de caráter, uma perpétua e preparada oposição à vontade da maioria",272. [Mill, 1838, p. 187-188].

${ }^{270}$ Mill, 1838, p.185.

${ }^{271}$ Mill, 1838, p. 187

272 Tradução livre de Mill, 1838, p. 187-188: There must, we know, be some paramount power in society; and that the majority should be that power, is on the whole right, not as being just in itself, but as being less unjust than any other footing on which the matter can be placed. But it is necessary that the institutions
} 
Mill coloca a importância da oposição à democracia quando a democracia torna-se um obstáculo ao desenvolvimento do indivíduo. Mill possui a opinião de que se todas as forças da sociedade agem em uma direção singular, há o perigo de opressão da minoria, bem como o perigo ou o problema de haver danos ao desenvolvimento do caráter do indivíduo. O poder da maioria é salutar desde que seja usado defensivamente e não ofensivamente em relação ao povo, desde que seu esforço seja temperado pelo respeito da personalidade individual e em defesa da superioridade do cultivo da inteligência (Mill deseja uma garantia de que a democracia proporcionará a defesa das individualidades dos indivíduos e proporcionará a oportunidade do cultivo da inteligência e a proteção da conveniência de autodesenvolvimento dos indivíduos ao longo do tempo). Bentham deveria se perguntar, por meio de quais instituições fundamentalmente democráticas devem ser mais bem adaptadas à preservação e fortalecimento destes dois sentimentos (os sentimentos de proteção das individualidades e de favorecimento ao autodesenvolvimento ou cultivo da inteligência).

Tendo esses temas em mente, Mill indaga: deveríamos nós considerar as especulações políticas de Bentham inúteis, se levarmos em consideração que se deve manter a liberdade de pensamento como uma condição necessária da liberdade individual? A resposta de Mill é muito simples: este autor considera os pensamentos políticos de Bentham muito úteis, porque ele limpou este campo de muitas confusões e tentou promover uma das qualidades ideais de um governo perfeito que é a identidade de interesse entre os administradores e a comunidade, entretanto, o interesse da minoria ou dos indivíduos em desenvolvimento em todos os jeitos possíveis encontra-se em perigo com a teoria da democracia de Bentham ${ }^{273}$.

Para Mill, Bentham apresenta pouco material, seu primeiro princípio não explica tudo ${ }^{274}$. Mill [Mill, 1838, p. 189] pensa a utilidade, ou a felicidade, de maneira

of society should make provisions for keeping up, in some form or other, as a corrective to partial views, and a shelter for freedom of thought and individually of character, a perpetual and standing Opposition to the will of the majority".

${ }^{273}$ Entretanto, pode-se argumentar a favor de Bentham, neste ponto, o fato de que o autor pensou o problema da minoria quando escreveu a Dentologia. Nesta obra o autor pensou que se uma minoria qualquer estivesse sendo oprimida por uma maioria estaria sofrendo uma dor muito intensa, então, a opressão da maioria não se justificaria.

${ }^{274}$ Mill, 1838, p. 189. 
muito mais complexa que Bentham, ela é um fim a ser perseguido por meio de vários fins secundários, segundo os quais deve haver e freqüentemente há acordo entre pessoas que diferem em seus padrões últimos de pensamento. A humanidade é muito mais facilmente colocada a concordar sobre os princípios morais intermediários que se deve seguir ${ }^{275}$, do que os princípios primeiros e mais propensa a referir-se aos princípios intermediários do que às generalizações mais altas. A humanidade está mais propensa a estimar o valor de uma ação fazendo referência direta aos princípios intermediários do que ao princípio da felicidade e isto já havia sido dito, quando se tratou de uma visão geral da Autobiografia do autor, pois quando este saiu de sua crise mental, ele estava convencido que a felicidade (fim último e único desejado por todos os homens) só poderia ser alcançada se princípios secundários fossem estabelecidos.

"Aqueles que adotaram a utilidade como um padrão
raramente podem aplicá-la verdadeiramente exceto por meio
de princípios secundários; aqueles que rejeitarem isto,
geralmente não farão nada mais do que construir princípios
secundários no lugar dos princípios primeiros
1838, p. 190].

Portanto, é muito claro que para Mill, a ética necessita ter princípios secundários e desta forma mais regras morais e não apenas um apelo constante aos primeiros princípios assim como a ética de Bentham o faz. O homem de Mill, portanto, não é um homem que faz cálculos a cada ação. A ética deste autor tem, definitivamente, mais espaço para regras morais, como será possível verificar no quarto e quinto capítulo desta tese.

De acordo com Mill, é apenas quando dois ou mais princípios secundários $\underline{\text { entram em conflito que um apelo direto a um princípio primeiro torna-se necessário }}{ }^{277}$, e

\footnotetext{
${ }^{275}$ Mill, 1838, p.189.

${ }^{276}$ Tradução livre de Mill, 1838, p. 190: Those who adopt utility as standard can seldom apply it truly except through the secondary principles; those who reject it, generally do no more than erect secondary principles into first principles".

${ }^{277}$ Mill, 1838, p. 190.
} 
então começa a importância prática da controvérsia do utilitarismo, que é, em alguma medida, uma questão de subordinação lógica ${ }^{278}$ entre princípios.

Conforme mencionado, anteriormente, Mill ataca o modelo de homem de Bentham dizendo que para este autor, o assunto felicidade é meramente uma questão de razão e cálculo ${ }^{279}$, e não também de sentimento moral (faculdades mais elevadas que dão origem a prazeres mais elevados), hábito, capacidade de desenvolver o caráter ao longo do tempo (modelo de indivíduo dinâmico), sendo que estas são idéias essenciais da filosofia moral de Mill, pois serão responsáveis por gerar um novo homem, um indivíduo com uma nova natureza humana que derivará um princípio da utilidade que requererá explicações do significado da busca pelo prazer e da dor, sendo que tais explicações traduzir-se-ão em princípios secundários, no campo da moralidade. A moralidade das ações em Bentham depende das consequiências que estas ações tendem a produzir. $\mathrm{O}$ bem ou mal destas consequiências é medido somente pela dor e prazer que geram e isto é tudo que a doutrina da utilidade de Bentham engloba. Mill afirma que Bentham não poderia conhecer profundamente o caráter do indivíduo porque Bentham sabiamente apenas soube impor limites ${ }^{280} \mathrm{em}$ assunto de ética prática, embora não pudesse conhecer o tema.

As consequiências de uma ação determinam o campo de estudos éticos de Bentham, Mill chama sua filosofia de fria, mecânica ${ }^{281}$ e de um ar não genial que caracteriza a idéia popular Benthamita. Mill continua indicando que a filosofia de Bentham é oposta aos sentimentos comuns da humanidade. Mill afirma que este erro pertence a Bentham e não ao utilitarismo. Portanto, é possível afirmar que se assume que Mill é um utilitarista, embora tenha muitas críticas à teoria de Bentham, como se tem mostrado.

\footnotetext{
${ }^{278}$ Uma resposta a esta questão de subordinação dos princípios secundários ao princípio da utilidade, bem como um enquadramento de Mill dizendo se ele é um Act Utilitarian ou Rule Utilitarian será dada no capítulo quarto desta tese.

${ }^{279}$ Bentham in Déontologie ou Science de la Morale p. 144: “[...]La raison fait servir les événements de l'un à l'instruction de l'autre: elle appelle à son aide non seulement l'expérience, mais encore l'imagination. Le domaine de son influence est sans limite comme la pensée: elle recherche les conséquences, et les présente aux regards de l'investigateur: elle dégage les peines et les plaisirs de l'alliage qui les accompagne: elle analyse leur valeur en les divisant dans leurs parties constitutives, ou les réunit en un tout afin de s'assurer de leur somme totale: elle les compare l'un avec l'autre quand ils sont classés chacun dans sa division respective, et de ces éléments réunis elle généralise et déduit le résultat définitif [...]".

${ }^{280}$ Mill, 1838, p. 190.

${ }^{281}$ Mill, 1838, p. 190.
} 
De acordo com Mill em seu ensaio de 1838, a ação humana possui três $\operatorname{aspectos}^{282}$ :

a) um moral (se isto é correto ou errado);

b) um estético (que se refere à beleza);

c) que diz respeito à simpatia (que diz respeito à amabilidade).

O primeiro aspecto endereça-se à razão e consciência, o segundo à imaginação e o terceiro aos sentimentos dos semelhantes. De acordo com o primeiro, aprova-se ou desaprova-se, de acordo com o segundo admira-se ou despreza-se, de acordo com o terceiro ama-se ou desgosta-se. A moralidade de uma ação depende de suas conseqüências, de sua beleza e do quanto gera amor ou o contrário. Portanto, uma mentira é errônea porque é má e porque tende a destruir a confiança dos homens uns nos outros ou os laços de simpatia e também porque tem um caráter estético.

O erro dos moralistas em geral e o erro de Bentham é não considerar as outras duas características (estéticas e simpáticas) quando a consideração é ética e considerar apenas o aspecto racional moral (relativas ao certo e errado), mesmo no sentido moral, tem-se mostrado que as colocações de Bentham são incompletas. Bentham escrevia e sentia como se os padrões morais não tivessem que ser apenas principais, mas únicos, como se fossem os únicos senhores das ações e mesmo dos sentimentos. Mill ressalta que existem algumas frases que Bentham não gostaria de ouvir em sua presença como bom gosto e gosto ruim, pois ele considerava que era uma insolente presença de dogmatismo em uma pessoa condenar ou premiar alguém em termos de gosto (lembrando apenas que Bentham criara o princípio de utilidade justamente para dar um fim ao dogmatismo nas opiniões e nas leis da vida pública em geral). Mill, por outro lado, diz ser muito importante conhecer os gostos e os desgostos dos homens sobre as coisas, porque os gostos das pessoas podem mostrar muito de seu caráter, se tal pessoa é ignorante ou culta, gentil ou rude, sensível ou insensível, generosa ou sórdida, benevolvente ou egoísta, conscienciosa ou depravada pode-se, a partir do conhecimento dos gostos das pessoas depreender seus caracteres. Desta forma, para além de uma

${ }^{282}$ Mill, 1838, p. 190. 
preocupação legal para com as conseqüências das ações dos indivíduos, Mill tem uma preocupação no que se refere aos dois aspectos mencionados (estético e simpático) que contribuem para a formação do caráter dos indivíduos, no campo ético, para a formação das regras morais e também para que conseqüências das ações sejam ocasionadas.

Fortemente conectado ao mesmo tema estão as peculiares opiniões negativas de Bentham sobre poesia. Música foi o divertimento favorito de Bentham, enquanto a pintura, escultura, e outras artes endereçadas aos olhos eram reconhecidas como meios importantes para que fossem atingidos certos fins sociais, entretanto, de acordo com Mill, sua ignorância de compreensão mais profunda de um caráter humano o impedia de ver maiores benefícios estéticos nessas artes. No que concerne à poesia, no entanto, Bentham, não empregou nenhum favor, as palavras, de acordo com ele, eram pervertidas de seu próprio ofício, quando empregadas em qualquer coisa que não fosse a verdade lógica. Para Bentham, toda poesia é má compreensão ${ }^{283}$. Poesia para Bentham era um exagero cometido pelo efeito de proclamar alguma coisa muito enfaticamente e suprimindo todas as limitações e qualificações. O caráter de Bentham parecia ser exatamente o que Carlyle chamava de "a perfeição do homem limitado" ${ }^{284}$ [Mill, 1838, p.192]. Contudo, qual seria o problema em ignorar poesia? O problema em ignorar a poesia consiste no fato de que Bentham ao fazê-lo estaria ignorando os sentimentos que tornam os homens propriamente humanos (ele aceita os sentimentos de prazer e dor apenas como aqueles pertencentes a um instrumento de uma razão calculadora), ignorando, portanto, importantes componentes da natureza ou características humanas, circunstâncias importantes que tornam o caráter humano mais excelente. Esta natureza interage com o mundo (sociedade) e formula neste mundo (entre diversas circunstâncias) uma moralidade ou regras morais próprias, não importando se esta ética pertence ao utilitarismo. O ponto de Mill refere-se ao fato de que é impossível construir uma ética positiva (não apenas uma ética negativa como no sentido de Bentham, desfazendo toda a moral dos costumes através do balanço entre prazer e dor; análise das consequiências das regras morais estabelecidas), com regras morais estabelecidas sem reconhecer características humanas tais como: sentimentos morais, o próprio agir por hábito,

\footnotetext{
${ }^{283}$ Mill, 1838, p,192.

284 "The completeness of limited men"
} 
faculdades humanas mais elevadas, capacidade de melhorar ao longo do tempo (ou de moldar o caráter), leis da mente, tão negligenciadas por Bentham. Quanto mais excelentes forem as circunstâncias às quais os indivíduos forem expostos para formarem seus caracteres, tanto melhores serão as regras morais derivadas deles, melhores serão os princípios secundários derivados do princípio primeiro (do princípio da maior felicidade). 


\section{Capítulo III - O Modelo de Indivíduo teórico de Mill (outra natureza humana, novas características, novo princípio de utilidade, novo método que embasa a moralidade).}

No capítulo anterior foi defendido que o utilitarismo de John Stuart Mill é um utilitarismo mais complexo porque anexa elementos de outros autores como Comte de poetas como Wordsworth e autores antigos à sua teoria além de seguir, parcialmente, a teoria de Bentham. Para tanto, tentou-se efetuar uma leitura genética psicológica por considerar que este autor é um autor psicologista, associacionista que possui uma rica experiência que o influenciou para a compreensão da formação de seu modelo de homem e sua moralidade. Disto depreende-se, a partir, principalmente, da análise de suas obras; Sistema de Lógica, Utilitarismo, A liberdade, Autobiografia, os Ensaios: Bentham, Coleridge, Comte e algumas cartas, que o autor não rejeitou o sistema teórico de Bentham, mas adicionou muitos elementos à teoria moral do utilitarismo deste autor tornando mais complexa a natureza humana de seu indivíduo e o próprio conceito de utilitarismo determinado por ele. Não obstante, sustentar-se-á que este autor continua seguindo a corrente hedonista e, portanto, utilitarista. Os principais autores que concordam com este trabalho em relação a esta tese são: [Crisp, 1997, 25-28, Donner, 2004, 8- 22, p.31-50, Riley, 2008, p. 258, Skorupski, 1989, 295-299, West, p.48-70]. O hedonismo ${ }^{285}$ em filosofia é a doutrina que ressalta que o prazer e a dor são os únicos bens ou males como fins, todas as outras coisas derivam seu valor ou não valor da relação com prazer ou dor, respectivamente. $\mathrm{O}$ hedonismo em filosofia não é o mesmo conceito do que aquele encontrado no senso comum. No senso comum o hedonismo, freqüentemente, significa buscar o prazer imediato, sem prestar atenção às consequiências de longo prazo, sem dar valor aos prazeres intelectuais, sem dar valor ao auto-respeito que vem de aquisições de deveres e encontram-se intimamente relacionados a relações de amor com outros e à amizade. O hedonismo de um utilitarista prestou atenção a todas estas fontes de prazer e não somente aos prazeres sensuais, além disso, o hedonismo de

${ }^{285}$ West. H. 2007, p. 9. 
Mill será mais complexo do que o de Bentham, porque terá uma série de subteses anexadas à tese principal hedonista que possibilitam que a busca do prazer e da dor se realize por meio de outros elementos da natureza humana para a realização do fim último de todo ser humano, a saber: a busca da felicidade. Ou seja, estas subteses irão derivar seu valor do prazer e da dor, fatos que aproximarão Mill de Bentham e nomearão Mill um utilitarista, mas ao mesmo tempo o afastarão de Bentham, pois ditarão certo conteúdo moral quando se pensa a moralidade de Mill em relação à moralidade de Bentham. Conceitos novos na sua natureza humana do indivíduo teórico de Mill, sempre derivando seu valor ao prazer e dor ou em associação a eles como Leis da Mente (natureza humana), faculdades humanas mais elevadas que precisam ser satisfeitas por prazeres humanos de qualidade mais elevada, em contraposição às faculdades humanas menos elevadas que se satisfazem com prazeres menos elevados, a capacidade de aperfeiçoar o caráter ao longo do tempo (característica de um modelo dinâmico de indivíduo) que podem convergir com os valores sociais (não por imposição, mas por livre vontade, por meio da educação e por meio do aperfeiçoamento das instituições), o agir por hábito (que leva à elaboração de princípios secundários ou regras da moralidade, pois permite que o indivíduo não faça cálculos a toda ação) são todos novos elementos da natureza humana ou subteses da natureza humana que têm sim em vista a felicidade ou derivam seu valor dela, portanto, estão submetidos a ela, à tese principal hedonista, mas afastam John Stuart Mill de Bentham e o transformam em um filósofo com um utilitarismo mais complexo em relação à Bentham ${ }^{286}$.

Entretanto, como Mill constrói este indivíduo com estas novas características em relação a Bentham, fica claro que isto se dá com o auxílio à história da filosofia, pois esteve imerso nesta desde uma idade bastante precoce e com seu método empírico, afinal este autor é um autor pertencente à escola empirista inglesa (reste claro que este empirismo não é um empirismo simples que extrai apenas leis empíricas das circunstâncias, mas efetua generalizações universais por indução, depois realiza uma série de deduções e então às compara às leis empíricas).

\footnotetext{
${ }^{286}$ Deve-se ter em mente que embora Mill tenha afastado-se de Bentham em seu ensaio de 1838 , ele aproximou-se deste autor, após este ensaio, confirmando o fato de ser um utilitarista, embora tenha acrescentado muito a este utilitarismo.
} 
Será demonstrado a seguir que a moral, para Mill, não é uma ciência, mas antes uma $\operatorname{arte}^{287}$, e toda arte, para este autor, deve estar ancorada em uma ciência. Desta afirmação surge uma pergunta, qual seja: como efetuar a ciência que embasará os ditames morais? Mill ressalta que em Ciências Sociais não se deve utilizar o método químico, pois é impossível realizar experimentos com seres humanos (sem mencionar o fato de que os indivíduos não se tornam outras coisas além de homens em sociedade como o que ocorre com hidrogênio em química quando misturado a uma certa porção de oxigênio possa transformar-se em água), de outra parte, também não se deve utilizar o método geométrico pois existem inúmeras e conflitantes causas que geram o complexo fenômeno social e não apenas uma como pressupõem aqueles que se utilizam deste método geométrico. Em outros termos, o problema deste método decorre do fato de efetuar-se um excesso de abstração, desconsiderando inúmeras causas inclusive conflitantes que operam para a geração do fenômeno; a Ciência Social seria mais próxima da mecânica do que da geometria, observando uma composição de forças conflitantes para explicação do fenômeno, portanto, ao invés de partir apenas de uma única causa para efetuar dedução para, então, explicar o fenômeno.

O método da Ciência Social é então dedutivo indutivo (inverso), extraído da física - não geométrico, e nisto Mill se afasta de Bentham, porque este último partiu de apenas uma premissa para deduzir todas as suas conclusões. Mill é crítico de Bentham conforme será demonstrado e foi descrito no segundo capítulo. O fato de sustentar-se neste trabalho o evento de que Mill continua operando com a tese hedonista não significa que este autor não mantenha inúmeras diferenças para com Bentham.

\section{A Formação do Modelo de Indivíduo para Mill}

O primeiro elemento central incluso na noção de natureza humana do indivíduo teórico de Mill refere-se às leis da mente. Estas leis são generalizações

\footnotetext{
${ }^{287}$ No sentido antigo da palavra que prescreve regras, preceitos.
} 
universais obtidas por indução e ditam a forma como funciona a mente humana ${ }^{288}$. Seguem abaixo tais leis:

Primeira lei: Toda impressão mental tem sua idéia. Isto significa que a um estado de consciência provocado nos indivíduos, um estado semelhante ao primeiro, mas inferior em intensidade é suscetível de ser produzido, sem a presença de nenhuma causa àquela que provocou inicialmente.

A segunda lei mental refere-se às leis de associação diz respeito às idéias ou estados mentais secundários que são provocados por impressões ou por outras idéias, de acordo com certas leis. No que diz respeito à primeira dessas leis, idéias similares tendem a se provocar umas às outras. De acordo com a segunda dessas leis, quando duas impressões foram repetidamente experimentadas (ou mesmo pensadas), simultaneamente, ou em sucessão imediata, então, sempre que uma dessas impressões, ou a idéia correspondente, retorna, a idéia da outra tende a ser provocada.

A terceira lei é denominada freqüência de conjunção, a maior intensidade em uma ou em duas impressões é equivalente, para torná-las aptas a se provocar umas às outras. Estas são leis de idéias que são remetidas a obras psicológicas, em particular à Análise do Fenômeno da Mente Humana, de James Mill ou à Investigação sobre o Entendimento Humano em que as principais leis de associação, bem como várias de suas aplicações, são exemplificadas.

Essas são as leis gerais da natureza humana (ou da mente humana) e foram estabelecidas pelo método ordinário indutivo de investigação experimental, entretanto, cada povo apresenta características culturais particulares que poderiam ser extraídas a partir das leis da história, também. Estas seriam as chamadas leis etológicas de um país, além de ainda haver as leis etológicas do caráter individual de um agente, em dadas circunstâncias.

Para explicar o fundamento da moral do indivíduo teórico de Mill, aliam-se as leis da natureza humana, às leis empíricas (leis da história) que geram a explicação ou o fundamento científico do princípio da maior felicidade que constitui o fundamento

\footnotetext{
${ }^{288}$ Essas leis podem ser também chamadas de leis lógicas, o principal problema de Mill em relação às leis lógicas parece ser o fato de que tais leis são estabelecidas por indução, ou seja são denominadas lógicas, mas passam pela experiência.
} 
científico da moralidade ${ }^{289}$. Em outras palavras, seja pela dedução da primeira lei da mente, pela dedução da segunda lei da mente ou da terceira, verificadas por leis empíricas, sempre se obterá como tese central e pilar das ações humanas o princípio da maior felicidade.

Ou seja, a lei empírica básica que se verifica é a de que os homens buscam a sua própria felicidade, bem como a finalidade da moralidade é a própria felicidade (reste claro que a finalidade da moralidade é a felicidade conjunta de todos os agentes, ainda que os agentes, muitas vezes ajam em busca, apenas de sua própria felicidade, a sociedade como um todo deve criar condições para fazer convergir a felicidade individual com a coletiva $\left.{ }^{290}\right)$. Entendida esta lei empírica, ela é verificada tantas vezes que é universalizada, assim como afirma, indiretamente, Mill em o Utilitarismo: "A única prova que se pode dar de que um objeto é visível é a de que as pessoas efetivamente o vêem [...]". "[...] Da mesma maneira, segundo creio, a única evidência que se pode apresentar de que algo é desejável é que de fato as pessoas o desejam” [Mill, 1861, p. 232].

Esta universalização é aplicada às leis da mente, como por exemplo à lei de associação: quando duas impressões foram freqüentemente experimentadas em sucessão imediata (por exemplo: uma ação A associa um prazer X e logo após realiza-se uma ação $\mathrm{B}$ que associa um prazer $\mathrm{Y}$ ) então a idéia da ação $\mathrm{A}$ gera a idéia do prazer $\mathrm{X}$ e além disso a idéia do primeiro prazer, quando vem à mente, pode trazer a idéia do segundo prazer, $\mathrm{e}$ assim por diante e as ações A e B são agradável constituindo tema de repetição, enquanto que se associassem dor trariam estados mentais desagradáveis e portanto tais ações não mais seriam praticadas, no que se refere à matéria de felicidade humana, estas leis são deduzidas e verificadas novamente na experiência e assim confirma-se a tese central do modelo de indivíduo teórico de Mill como sendo a tese hedonista, segundo a qual o prazer e dor são os únicos bens ou males em si e todas as outras coisas derivam seu valor destes elementos. Entretanto, em casos morais as circunstâncias sempre terão um papel fundamental para decidir qual é a melhor ação. Além disso, outras subteses estarão

\footnotetext{
${ }^{289}$ Mill, 1861, p.55.

${ }^{290}$ Devem ser criados elementos educacionais e institucionais para que o indivíduo queira agir de forma a fazer convergir seus interesses com os da sociedade, através da sanção interna, um certo sentimento de remorso quando descumpre seu dever moral (não gerar dor, ou gerar prazer em algumas circunstâncias).
} 
anexadas à tese hedonista de Mill, uma vez que está de acordo com o modo de explicar o complexo fenômeno social, adicionar leis da natureza humana para ser capaz de abarcar o máximo possível a totalidade do fenômeno.

O princípio da utilidade reconhece esta tese como sendo a norma ou a única norma de ação justa e a transforma em pilar da moralidade (ou converte este teorema da ciência de que é da natureza humana buscar o prazer e fugir da dor em primeiro preceito moral). Os princípios secundários têm sua origem no primeiro princípio, mas se perpetuarão como tal, devido a outros elementos da natureza humana, ainda que estes elementos estejam subordinados à tese hedonista ou à associação com o benefício ou derivem seu valor da felicidade. O princípio primeiro, conforme mencionado era o princípio de utilidade que apesar de ser o fundamento da moral utilitarista, não deixa de ser um preceito. Os princípios secundários ou outras regras da moral são: não matarás, não roubarás, aprecie a arte, estude, obtenha prazeres humanos (de qualidade superior), etc. Estas regras (além do princípio de utilidade) fazem parte da moralidade, são os chamados princípios secundários, constituem uma arte ${ }^{291}$. Poder-se-ia argumentar que Bentham também formula o princípio de utilidade. Contudo, Mill acrescentará que muito deve ser dito para que se entenda o que está incluído nas idéias de dor e prazer. Em outras palavras, muito deve ser dito em moralidade, para que se entenda o que está incluído nas idéias de dor e prazer. Ou seja, há mais espaço para a formulação de regras morais no utilitarismo de Mill, quando comparado ao de Bentham, apesar de Mill continuar sendo um utilitarista.

"O Credo que aceita a utilidade ou o princípio da maior felicidade como a fundação da moral sustenta que as ações são corretas na medida em que tendem a produzir a felicidade. Por felicidade se entende prazer e a ausência de dor; por infelicidade, dor e a privação do prazer. Para dar uma idéia clara do padrão moral estabelecido pela teoria, é preciso dizer muito mais; trata-se de saber, em particular, $o$ que está incluído nas idéias de dor e prazer e em que medida esse debate é uma questão aberta”.[Mill, 1861 p. 187 2.2]

${ }^{291}$ Mais uma vez ressalto que constitui uma arte no sentido antigo. 
Além dessas características da natureza humana deve-se levar em conta que o modelo de indivíduo teórico de Mill é dinâmico, uma vez que ele possui uma característica implícita em sua natureza que é a capacidade de melhorar seu caráter (etologia) ao longo do tempo, porque as circunstâncias estão em constante transformação e afetam as leis etológicas. Em outros termos, se em algum momento do tempo, Mill vislumbra que os homens agem egoisticamente, eles carregam em sua natureza um elemento que permite que deixem de ser apenas auto-interessados e passem a fazer convergir seus interesses com os interesses da sociedade ${ }^{292}$, apenas é necessário que os arranjos institucionais, educacionais sejam favoráveis.

Outra característica fundamental da natureza humana e que dará constância às regras morais pertencente à arte da moralidade é o hábito. O hábito, assim como, a capacidade de desenvolver o caráter ao longo do tempo, deriva seu valor da capacidade que possui de conduzir o indivíduo à felicidade e também pode ser considerada como sendo derivada de uma lei empírica ou da ciência, assim como todas as características da natureza humana do indivíduo teórico de Mill.

Outro elemento da natureza humana constitui as faculdades mais elevadas que os indivíduos possuem, a estas faculdades estão associados prazeres mais elevados, como prazeres intelectuais que podem ser despertados, conforme a capacidade de melhorar ao longo do tempo do indivíduo também seja despertada. Às faculdades mais elevadas estão associadas faculdades menos elevadas que dão origem a prazeres menos elevados (como prazeres que satisfazem necessidades básicas dos homens).

A metodologia de descoberta de leis sociológicas, para Mill, é fundamental, pois tais leis formarão esta natureza humana denominada, nesta tese, de mais complexa. Tais leis serão submetidas, constantemente, a inúmeras circunstâncias e formarão diversos caracteres existentes, dando origem a um princípio de utilidade diverso, quando comparado ao de Bentham (conforme explicado muito mais coisas precisam ser ditas para que sejam entendidas as idéias de prazer e dor), resultando, por fim na elaboração de princípios secundários ou um maior número de regras morais relativamente à moral de Bentham. Os elementos da natureza humana do modelo dinâmico do indivíduo teórico de

\footnotetext{
${ }^{292}$ Reste claro que não é uma obrigação moral, agir conforme os interesses dos outros, em detrimento dos interesses próprios. Ver parágrafo 5.14 do Utilitarismo p. 252 "Razões de prudência, ou o interesse de outras pessoas, podem contra-indicar que efetivamente seja exigido".
} 
Mill que descrevi são: a) a capacidade de melhorar ao longo do tempo, b) o hábito e c) faculdades mais elevadas, que derivam seu valor da tese hedonista (da capacidade que tem de gerar prazer e de abster-se de gerar dor) e, portanto, convertem do teorema científico um princípio moral, da natureza humana que embasa a arte, a moralidade, gerando o princípio de utilidade. As leis da mente seriam as leis da natureza humana, das quais extraem-se as leis científicas de todos os campos das ciências sociais, não apenas de uma Ética que embasaria a moralidade ou de um Ciência Política, mas também da Psicologia, Economia, etc, elas são as leis lógicas (que também encontram-se no modelo de indivíduo).

Disto, pode-se depreender que para construir as ciências sociais, torna-se necessário realizar uma espécie de combinação entre as leis empíricas, leis também etológicas (neste caso significa entender as leis causais do caráter dos indivíduos e disto também depende levar em conta relações com os outros, com os arranjos sociais vigentes, as circunstâncias sociais) e leis da mente. Portanto, Mill usa psicologia para pronunciarse sobre leis científicas, sobre epistemologia.

Explica-se abaixo, de que forma é possível entender a metodologia de Mill e sua relação com as ciências sociais, os métodos que não devem ser aplicados em ciências sociais (químico, geométrico), os que devem ser aplicados (método físico indutivo dedutivo e verificacionista, por composição de causas, e inclusive nas ciências que servem de base à moralidade, a saber: aquela que procede pelo método dedutivo (inverso) -indutivo.

\section{Que Existe uma Natureza Humana e que Ela Possui Certas Leis.}

No capítulo terceiro do livro VI do Sistema de Lógica o autor realiza uma defesa da possibilidade de existência de uma ciência da natureza humana. Desta forma, Mill inicia sua defesa de que é possível realizar uma ciência da natureza humana, embora o senso comum ressalte que os pensamentos, os sentimentos, e as ações dos seres humanos não são matéria de ciência, no mesmo senso estrito no qual é verdade para os objetos de natureza corpórea. Esta noção, de senso comum, entretanto, de acordo com Mill, parece envolver alguma confusão de idéias que facilmente pode ser desfeita. Em 
outros termos, os pensamentos, sentimentos e ações dos seres humanos podem sim ser matéria de ciência, assim como os objetos de natureza corpórea ${ }^{293}$.

De acordo com Mill, quaisquer fatos estão qualificados a constituir matéria de ciência, embora as leis possam não ser descobertas, pelos recursos existentes, até o momento em que o autor vivia. O autor sugeriu no Sistema de Lógica que fosse tomado, como exemplo, a classe mais familiar de fenômenos meteorológicos como a chuva e os raios do sol. Até aquele momento, uma pesquisa científica ainda não havia sido bem sucedida em determinar a ordem do antecedente e conseqüente sobre estes fenômenos, também não haviam sido hábeis em prevê-los com certeza, ou mesmo com algum grau de probabilidade. No entanto, ninguém duvidaria que estes fenômenos dependam de leis, do calor, da eletricidade, da vaporização e dos fluidos. Tão pouco se duvidaria que caso conhecidas todas as circunstâncias antecedentes seria possível prever (salvo dificuldades de cálculo) o estado do tempo em qualquer tempo futuro.

A meteorologia, assim, não apenas possui todos os requisitos naturais para ser uma ciência, como de fato é, a dificuldade em prever o tempo não está no fato desta não ser uma ciência, mas sim na dificuldade em observar os fatos dos quais o fenômeno depende, o mesmo ocorreria com as ciências sociais.

Mill realiza uma diferenciação entre ciência mais exata (aquela em que compreende-se a totalidade das causas e é possível mensurá-la) e menos exata (aquela em que as previsões se distanciam da ocorrência dos fenômenos por não se conhecer ou poder-se mensurar o todo das causas, especialmente as causas secundárias ou menos importantes). Entretanto, combinando as leis das grandes causas e as leis das menores causas, respeitando suas variações em relação às observações, pode-se realizar proposições que serão verdadeiras na maioria dos casos aplicados, e desta forma, obter resultados aceitáveis como previsões. Ou seja, é perfeitamente possível realizar ciência social, a dificuldade está, apenas em conhecer as leis desta ciência, devido à complexidade do fenômeno.

A pergunta que deve ser colocada, então, seria: qual tipo científico corresponde às ciências da natureza humana? Ressalta o autor ${ }^{294}$, a ciência da natureza

\footnotetext{
${ }^{293}$ Mill (1843), 1999, p. 41. (edição liberty fund)

${ }^{294}$ Mill, (1843), 1974, p. 845. (edição liberty fund)
} 
humana é a da descrição. Ela tem conseguido um menor padrão de exatidão do que aquele auferido na astronomia, mas não há razão para não ser considerada ciência assim como a Astronomia ou a ciência que explica as marés, quando seus cálculos abrangem os principais fenômenos.

Conforme mencionado, os fenômenos que dizem respeito a esta ciência são os pensamentos, os sentimentos e as ações dos seres humanos (ações estas que sempre possuem um aspecto moral, estético e simpático, conforme mencionado no capitulo anterior) e a partir desta afirmação de Mill torna possível pensar que o autor concebe a $\underline{\text { sociedade a partir do indivíduo }}{ }^{295}$, já que descreve que os fenômenos que se referem às ciências humanas são aqueles condizentes com as características dos seres humanos. Levando em conta estes fatores, o ideal de perfeição da ciência ocorreria caso ela permitisse prever como um indivíduo pensa, sente e age durante sua vida, submetido às circunstâncias a que é submetido, com a mesma certeza que a astronomia permite prever os lugares dos corpos no espaço.

As impressões e ações dos seres humanos não são somente resultado das circunstâncias presentes, mas o resultado conjunto daquelas circunstâncias e do caráter dos indivíduos. Esta combinação do caráter e natureza humana com circunstâncias e fatos históricos permeia todo livro VI do Sistema de Lógica publicado pelo autor em 1843, pois é desta combinação que se torna possível estabelecer as leis em ciências sociais.

De acordo com Mill, os determinantes do caráter humano são tão inúmeros e diversificados (nada que ocorreu na vida de uma pessoa deixa de ter sua porção de influência) que no conjunto estes determinantes nunca são os mesmos para dois indivíduos ${ }^{296}$. Assim, mesmo se a ciência da natureza humana fosse perfeita e fosse possível calcular qualquer caráter de um indivíduo como se calcula a órbita de um planeta, ainda sim, como os dados nunca estão completos (pois as circunstâncias nunca cessam de influenciar o caráter de uma pessoa), e dois casos nunca são totalmente semelhantes, jamais se poderiam realizar previsões positivas, ou formular proposições universais.

\footnotetext{
${ }^{295}$ Mill, (1843), 1999, p. 44.

${ }^{296}$ Mill, (1843), 1974, p. 845. (edição liberty fund)
} 
Entretanto, visto que muitos dos efeitos de maior importância estão determinados, principalmente, por causas gerais, quando comparados a causas parciais (mais difíceis de prever), dependendo principalmente das circunstâncias e qualidades que são comuns a toda humanidade, ou ao menos, comuns à maior parte dela e contando que as influências de idiossincrasias da organização da história peculiar individual de um indivíduo possui um peso menor nas previsões e proposições gerais que possam ser feitas, torna-se possível realizar previsões e proposições gerais com um amplo grau de verdade. Para os propósitos de ciência política e social estas proposições gerais e previsões são suficientes.

Conforme observado pelo autor, uma generalização aproximada é, em pesquisas sociais, equivalente a uma generalização exata, pois quando aplicada à conduta do caráter coletivo das massas é dita certa. É afirmada apenas provável quando aplicada a indivíduos selecionados indiscriminadamente ${ }^{297}$.

Entretanto, para dar um caráter genuinamente científico ao estudo, é indispensável que estas generalizações aproximadas sejam conectadas dedutivamente às leis da natureza das quais elas resultam, devem ser ligadas às causas das quais dependem. Em outras palavras, a ciência da natureza humana deve ser dita existir como as verdades aproximadas que compõem o conhecimento prático da humanidade. Podem ser exibidas como corolários das leis universais da natureza humana.

Esta proposição, referente ao fato das ciências da natureza humana deverem estar conectadas às leis naturais das quais são efeitos, constitui a base do que enuncia conexão da ciência da natureza humana às leis da mente e do que exprime por leis da formação do caráter de um indivíduo.

\section{Um Componente da Natureza Humana: as Leis da Mente}

Conforme adiantado no capítulo segundo e no início deste capítulo quando foi descrito o modelo de indivíduo teórico de Mill, apresenta-se nesta seção, com maiores detalhes, o termo leis da mente, tão importante para que se entenda como forma-se o modelo de indivíduo do autor e, conseqüentemente, seu conceito de natureza humana.

${ }^{297}$ Mill, (1843), p.847 (edição liberty fund). 
Mill ressalta que se deve entender por leis da mente, aquelas que se referem ao fenômeno mental dos vários sentimentos ou estados de consciência do ser humano. Estes consistem em pensamentos, emoções, volições e sensações. É usual, entretanto, falar em sensações como estados do corpo, não da mente. Contudo, esta é uma confusão comum, a saber: dar um único nome a um fenômeno e à sua causa próxima.

O antecedente imediato da sensação é um estado do corpo, mas a sensação, ela própria, é um estado da mente. Se a palavra mente significa algo, significa aquilo que sente. $\mathrm{O}$ autor diz que qualquer opinião que se tenha a respeito da identidade ou diversidade fundamental do termo mente, em qualquer caso a distinção entre fatos mentais e físicos, entre mundo externo e interno, sempre permanecerá como assunto de classificação, sendo que nesta classificação as sensações, como todos os outros sentimentos, devem ser colocados como fenômenos mentais. O mecanicismo de suas produções, ambas no corpo e no que é chamado natureza exterior, é o que pode ser classificado como físico.

Os fenômenos da mente, então, são constituídos como pensamentos, emoções, volições e sensações. Desta forma, Mill evitará todas as especulações a respeito da natureza da mente e entenderá por Leis da Mente as leis dos fenômenos mentais, dos vários sentimentos ou estados de consciência dos seres que sentem. É comum referir-se às sensações como estados do corpo e não da mente, mas isto é uma confusão comum que se refere a dar o mesmo nome ao fenômeno e à sua causa próxima. A sensação é um estado da mente, enquanto que o antecedente imediato ao estado da mente é designado um estado do corpo. Portanto, o termo espírito quer dizer aquilo que sente ${ }^{298}$. As sensações, como todos os outros sentimentos, devem ser colocadas entre os fenômenos mentais. O que se pode classificar como físico é algum tipo de mecanismo externo que produz a sensação no corpo.

As leis da mente, desta forma, dizem respeito à forma como os sentimentos da natureza humana (mentais, fenômenos da mente) se causam uns aos outros e designam-se estados mentais como pensamentos, emoções, vontades e sensações.

Volto a afirmar (conclusão já colocada no capítulo II desta tese) que é importante notar que essas conclusões extraídas do livro sexto do Sistema de Lógica de

${ }^{298}$ Mill, (1843), 1999, p. 47. 
John Stuart Mill a respeito do que o autor entende por leis da mente não foram formuladas apenas pela leitura dos escritos de seu pai sobre psicologia analítica, conforme mencionado, mas os escritos de Berkeley, Hume, Reid, Dugald Stewart e Brown foram fundamentais para que Mill chegasse a essas conclusões. Vai-se mais longe nesta tese e afirma-se que o autor fornece elementos para a elaboração de seu modelo de indivíduo pronunciando que um dos fatores fundamentais para a elaboração deste modelo é que se leve em consideração que a mente possui certas leis determinadas. Além disso, é necessário considerar que ele extrai estas leis por indução. De acordo com o autor todos os estados da mente ou são imediatamente causados ou por outros estados da mente, ou por estados do corpo. As relações da ciência da mente com a ciência da fisiologia nunca devem ser negligenciadas ou subestimadas, pois não é preciso esquecer que as leis da mente podem ser leis derivadas resultantes das leis da vida animal e que sua verdade, portanto, pode depender, em última instância, de condições físicas, e a influência dos estados ou mudanças fisiológicas na alteração ou neutralização das sucessões mentais constitui uma das partes importantes do estudo psicológico. Entretanto, parece um grande erro a Mill rejeitar o recurso à análise psicológica e construir a teoria da mente unicamente sobre os dados que a fisiologia fornece. Por mais imperfeita que seja a ciência da mente, afirma-se que ela estava, naquele momento, muito mais avançada do que a parte correspondente da fisiologia e que abandonar a ciência da mente em favor da fisiologia, parecia ser uma infração à indução, pois a partir desta também era possível afirmar a existência da ciência da mente. Ou seja, por indução é possível afirmar que existe uma ciência da mente. Sem esta seriam produzidas conclusões errôneas em partes importantes da ciência da natureza humana.

Desta forma, entende-se que:

"a Psicologia tem, então, por objeto as uniformidades de sucessão, as leis, últimas ou derivadas, de acordo com as quais um estado mental sucede o outro - é causado por outro ou, pelo menos, cuja causa o faz seguir outro estado mental. Dessas leis, algumas são gerais, outras mais especiais. As que seguem são exemplos das leis mais gerais.” (Mill, 1843, 1999, p 50). 
A primeira lei da mente enunciada por Mill e já mencionada neste trabalho, anteriormente, é a seguir formulada: não importa qual seja a causa que tenha gerado um determinado estado de consciência, um outro estado de consciência semelhante, mas com intensidade menor é passível de ser produzido nos seres humanos, sem a presença da causa do primeiro estado. Desta forma, é possível que os homens relembrem alegrias ou pesares passados, sem que nenhum acontecimento feliz ou doloroso novo ocorra. Da mesma forma, um indivíduo pode pensar um objeto ainda que esteja ausente da visão e do tato, como ocorre com a primeira experiência. Enuncia-se esta lei expressando que toda impressão mental tem sua idéia.

A segunda lei mental é denominada leis de associação. A primeira dessas leis enuncia que idéias similares tendem a se provocar umas às outras. A segunda dessas leis elenca que quando duas impressões foram freqüentemente experimentadas (ou mesmo pensadas), simultaneamente ou em sucessão imediata, então, sempre que uma dessas impressões, ou a idéia correspondente, retorna, a idéia da outra tende a ser provocada $^{299}$.

A terceira lei enuncia que a maior intensidade em uma ou nas duas impressões é equivalente, para torná-las a se provocar umas às outras, a uma maior freqüência de conjunção ${ }^{300}$. Estas são leis de idéias que são remetidas a obras psicológicas de diversos autores como Berkeley, Hume, Reid, Dugald Stewart e Brown, em particular à Análise do Fenômeno da Mente Humana, de James Mill em que as principais leis de associação são exemplificadas.

Conforme afirma Mill, no capítulo VI do Sistema de Lógica, essas leis da mente foram determinadas pelos métodos da investigação experimental (indução) e, de acordo com o autor, não poderiam ser estabelecidas de outra maneira. Estas constituem leis simples da mente que devem gerar leis mais complexas da mente e assim explicar fenômenos mais complexos próximos da realidade. As leis da mente às vezes são análogas às leis da mecânica e, portanto, operam por composição ou soma dos fenômenos e outras vezes são análogas às leis da química. Esta discussão ocupa um importante lugar na teoria da indução. Quando as leis da mente são análogas às leis químicas isto ocorre

\footnotetext{
${ }^{299}$ Mill, (1843), 1999, p. 50

${ }^{300}$ Ibid.
} 
porque da conjunção de inúmeras idéias e impressões resulta uma nova idéia mais complexa. No exemplo de Mill; quando impressões foram experimentadas com freqüência e em conjunção, cada uma delas evoca pronta e instantaneamente as idéias do grupo todo, estas idéias misturam-se e fundem-se aparecendo não muitas, mas uma única. A ilustração ocorre com as sete cores do prisma, quando se sucedem rapidamente geram o branco, mas não são elas mesmas o branco, do mesmo modo pode-se pensar a formação das idéias, pois as mais complexas resultam da mistura das idéias mais simples e não consistem nelas. Este, portanto, é um caso da química mental em que é mais apropriado dizer que idéias simples geram outras mais complexas do que as compõem ${ }^{301}$. Em outras palavras, algumas idéias complexas se dão por composição (por soma) e estas vêm da física ou dinâmica e outras resultam ou são geradas por idéias mais simples, casos da química mental.

No que diz respeito a todos os outros elementos da mente, suas crenças, suas concepções mais abstrusas, seus sentimentos, emoções e volições, se a investigação for sobre sentimentos morais ${ }^{302}$, por exemplo o sentimento de reprovação moral, torna-se necessário comparar por meio de uma associação todas as ações ou estados mentais que são sempre moralmente condenáveis com uma classe de idéias particulares condenadas, na mente daquele que condena (se isto confirmar-se tem-se a concordância entre as ações moralmente condenáveis, com idéias condenáveis), sendo este método denominado o método da concordância. Adicionalmente a este método tem-se o método da diferença que consiste em verificar se a uma associação de um conjunto de idéias detestáveis a uma ação indiferente torna a ação moralmente reprovável. Ao responder afirmativamente a esta questão prova-se como uma lei de associação do tipo descrito é a causa geradora da reprovação moral ${ }^{303}$.

"Pode-se observar que as leis gerais de associação prevalecem entre esses estados mentais mais intrincados da mente da mesma forma como prevalecem entre os estados mais simples. Um desejo, uma emoção, uma idéia da mais alta ordem de abstração, mesmo nossos juízos e vontades,

\footnotetext{
${ }^{301}$ Mill, (1843), 1999, p.52.

${ }^{302}$ Mill, (1843), 1999, p.53.

${ }^{303}$ No caso dos sentimentos morais, o experimento direto é, em larga medida, substituído pela experiência histórica.
} 
quando se tornam habituais, são evocados por associação conforme, precisamente, as mesmas leis que nossas idéias simples" [Mill, 1843, p. 54].

Um desejo, uma idéia da mais alta ordem de abstração, uma emoção, os juízos e vontades, quando se tornam habituais, são evocados por associação conforme as idéias simples. Desta forma, no que diz respeito a uma crença, os psicólogos sempre terão que investigar sob quais leis uma crença é produzida, de que forma uma crença gera outra e por quais leis a mente correta ou erroneamente reconhece uma coisa como causa de outra. Por exemplo, no que diz respeito ao desejo, os psicólogos terão que investigar quais causas levam os homens a desejar coisas originalmente indiferentes ou mesmo desagradáveis $^{304}$. As leis gerais de associação prevalecem entre esses estados mais intricados da mente assim como predominam os estados mais simples.

Para Mill, diferenças naturais podem ser ditas existir nas predisposições ou suscetibilidades mentais e tais diferenças são, em muitos casos, conectadas com diversidades orgânicas, entretanto, não se segue daí que tais diferenças orgânicas devam, em todos os casos, influenciar os fenômenos mentais, pois muito freqüentemente, as diversidades orgânicas afetam os fenômenos mentais por meio de causas psicológicas. O que foi expresso acima pode ser ilustrado através da idéia de um prazer particular que pode excitar em diferentes pessoas diferentes intensidades de desejo e a causa destas diferentes intensidades de desejo poderia ser diferentes tipos de suscetibilidades orgânicas (supondo que este prazer não seja causado pela educação ou pelo hábito). Essas diferentes suscetibilidades orgânicas tornariam a sensação de prazer mais intensa em uma dessas pessoas do que em outras, sendo que a idéia do prazer será também um sentimento mais intenso e irá, por meio da operação das leis mentais gerar um desejo mais intenso, sem que seja necessário supor que o desejo é diretamente influenciado pela peculiaridade física $^{305}$. Mesmo os diferentes tipos de caráter mental, serão naturalmente produzidos por

\footnotetext{
${ }^{304}$ Mill, (1843), 1999, p. 54.

${ }^{305}$ A questão de saber se causas orgânicas exerciam alguma influência direta sobre outras classes de fenômenos mentais estavam longe de ser resolvidas, no momento de Mill, como a natureza precisa das condições orgânicas que determinam os próprios instintos. Mill ressaltava que a frenologia (o estudo do crânio de modo a determinar seu caráter e sua personalidade) era insustentável como de fato se provou. No que concerne aos estados da mente chamados de sensações que possuem, conforme foi dito, por antecedentes imediatos estados do corpo, diz-se que têm por causa próxima alguma afecção da parte do
} 
meras diferenças de intensidade nas sensações em geral, podendo ser explicados pelas leis mentais, sem que seja necessário recorrer a diferenças orgânicas.

Ele notou que as sensações que formam os elementos de todo conhecimento são recebidas, ou simultaneamente, ou sucessivamente; quando várias são recebidas simultaneamente, como o aroma, o sabor, a cor, a forma, etc. de uma fruta, a associação entre elas constitui a idéia de um objeto, quando são recebidas sucessivamente, a associação forma a idéia de um evento. Tudo aquilo que favorece as associações de idéias sincrônicas produz um conhecimento de objetos, uma percepção de qualidades, enquanto que tudo aquilo que favorece a associação na ordem sucessiva produz um conhecimento de eventos, da ordem de ocorrência de causa e efeito. Em outros termos, quando as sensações ocorrem simultaneamente tem-se uma mente perceptiva que carrega uma capacidade de distinguir as propriedades agradáveis e desagradáveis das coisas, um sentido do sublime e do belo, por outro lado quando as sensações são recebidas simultaneamente tem-se uma mente atenta aos movimentos e aos fenômenos, obtém-se como resultado uma mente raciocinante e filosófica, com a forte característica de utilizarse da lei de causa e efeito. Todas as sensações experimentadas simultaneamente à presença de qualquer impressão vívida se tornam fortemente associadas com ela e umas com as outras; segue-se daí que os sentimentos sincrônicos estão mais intimamente ligados do que em uma mente formada de modo diferente. Esta sugestão leva à inferência de que um homem estimulado a ter mais tipos de associações sincrônicas do que outros tipos, provavelmente, possuirá gosto pela história natural, amor às coisas belas e

organismo denominada sistema nervoso. As leis dessa parte da natureza humana estão sob abrangência da Fisiologia.

A questão toda reside em saber se os demais estados mentais dependem de condições físicas e se, talvez, estejam sob abrangência da fisiologia. Muitos fisiologistas sustentariam que pensamentos, emoções e vontades poderiam ser resultado de uma ação nervosa. Segundo esses fisiologistas, um estado da mente nunca seria realmente produzido por outro: todos os estados da mente seriam produzidos por estados do corpo. Para eles a associação nunca teria ocorrido entre dois pensamentos, mas entre dois estados do cérebro ou que precederam os pensamentos, ou seja, um desses estados evoca o outro e cada um é acompanhado, pelo estado de consciência particular que é sua consequiência. De acordo com esta teoria (dos fisiologistas), as sucessões entre os estados da mente seriam derivadas de leis de sucessão dos estados corporais que os causam. Seguindo a lógica dos fisiologistas não haveria leis da mente no sentido como Mill emprega. De acordo com isso, Comte reivindica para os fisiologistas exclusivamente o conhecimento científico dos fenômenos intelectuais e morais e não somente nega à Psicologia ou Filosofia Mental propriamente dita o caráter de ciência mas as coloca, pela natureza quimérica de seus objetos e pretensões, quase ao mesmo nível da Astrologia. Embora, conforme explanado anteriormente, esta sucessão entre estados da mente possam ser explicados apenas em termos de leis da mente, sendo que Mill não aceita esta explicação fisiológica como uma explicação aceitável para a sucessão da formação das leis mentais. 
magníficas e entusiasmo moral; enquanto uma sensibilidade apenas dotada de associação simultânea resultará no amor à ciência e à verdade abstrata e pode resultar como uma deficiência de gosto e fervor.

Mill ressalta que os instintos ou a parte fisiológica podem ser dominados ou até mesmo modificados nos seres humanos ou até mesmo em animais domésticos, por meio de influências mentais, sendo que uma das causas pode ser a educação.

4. Outro componente da natureza humana: A formação do caráter como dependente das circunstâncias; a etologia.

A outra parte da natureza humana, então, que deve ser compreendida, refere-se à etologia ou à ciência da formação do caráter. O motivo pelo qual Mill referese às leis da mente e à etologia ou formação do caráter é bastante forte, pois estas constituirão a natureza humana e, portanto, formarão a base a qual pode ser feita ciência humana, ou o fundamento da ciência moral.

As leis etológicas nada mais são do que leis que explicam o caráter de um determinado indivíduo ou de uma nação, elas são denominadas leis causais, porque explicam as leis empíricas, (observadas na experiência). As leis etológicas são denominadas por Mill de leis do meio, ou axiomata media, porque estão entre as generalizações mais altas (leis da mente) e as generalizações mais próximas ao limite da observação e da experiência denominadas leis empíricas.

As leis etológicas ou de formação do caráter são deduzidas das leis mais gerais da mente, supondo um conjunto qualquer de circunstâncias. A partir dessas deduções considera-se qual será a influência dessas leis sob a formação do caráter. Desta forma, observar que o caráter dos idosos é cauteloso e dos jovens é impetuoso significa formular leis empíricas, pois não é a juventude que faz os jovens impetuosos nem a idade que traz cautela aos idosos. É simplesmente porque os idosos durante sua larga existência experimentaram vários males e estando mais expostos a estes males tornaram-se mais cautelosos (adquiriram associações de circunspecção) ${ }^{306}$, enquanto os jovens, por falta dessas experiências, tornam-se impetuosos. As leis etológicas ou leis causais que de fato

${ }^{306}$ Mill, (1843), 1874, p.862 (edição liberty fund). 
explicam as leis empíricas seriam então as seguintes: que a experiência tende a gerar cautela (ou prudência nas palavras de Mill) não que seja sempre o efeito, que a falta de experiência tende a ocasionar impetuosidade, não que seja sempre o efeito também.

Existe, contudo, uma finalidade humana, que compõe o caráter dos indivíduos e pode-se dizer que é ao mesmo tempo lei empírica (que restará claro, mais adiante qual é o significado) e ao ser combinada com as leis da mente e deduzida e novamente verificada com a lei empírica é prova da finalidade daquilo que os homens desejam e que compõem seu caráter, pode-se ser denominada de lei etológica também. Tem-se denominado neste trabalho de tese hedonista. Ela pode ser descrita, inicialmente, como uma lei empírica porque é observado que os homens desejam a felicidade, buscam o prazer e fogem da dor, esta lei pode ser conectada à lei de associação de sucessão, por exemplo, então, a uma ação $\mathrm{A}$ há associação de um prazer $\mathrm{B}$, a uma ação $\mathrm{C}$ associa-se um prazer D e está associado a estados mentais agradáveis, se as ações (A e C) foram realizadas sucessivamente geram idéias de prazeres B e D associados às idéias das ações A e C, sempre que pensadas chamarão os prazeres B e D, com estados mentais agradáveis, comparando essas conclusões com a lei empírica da qual se partiu tem-se a verificação, novamente e a tese hedonista é provada, os indivíduos buscam prazer e fogem da dor e por seu valor intrínseco, ou seja, neste caso a lei etológica (a busca de prazer) é também explicação da lei empírica busca de prazer, porque prazer tem valor intrínseco, as pessoas buscam prazer pelo prazer. Poder-se-ia dizer que todas as outras leis etológicas, ou leis que estão entre as leis da mente e as leis empíricas estão subordinadas a esta. Isto não significa que elas não tenham muita importância para explicar o complexo fenômeno social, isto não significa que elas não serão importantes para converter teoremas científicos em preceitos de moralidade (uma arte que se funda na ciência) e mesmo descobrir outras leis da natureza humana. Por exemplo, que os homens agem por hábito para ter constância no caráter e assim atingir a felicidade, também poderia ser uma lei etológica, poder-se-ia utilizar exatamente o mesmo procedimento científico para extrair esta lei de natureza. A única diferença seria que o hábito está submetido à tese principal hedonista, assim como as faculdades mais elevadas que produzem prazeres mais elevados e a capacidade que o indivíduo tem de transformar-se ao longo do tempo. Essas seriam as principais leis da natureza humana identificadas para, 
além das leis lógicas mentais. Outras leis etológicas menos importantes, mas ainda de bastante valia poderiam ser identificadas para serem ensinadas aos indivíduos (como tendências hipotéticas), embora Mill ressaltasse que este ramo da ciência fosse o menos desenvolvido até então.

As proposições das leis etológicas são hipotéticas e afirmam tendências, não fatos. Estas proposições não são menos universalmente verdadeiras porque as tendências podem ser frustradas, suas tendências podem ser frustradas devido à complexidade do fenômeno. Tendo em vista esta breve explicação das leis etológicas, realiza-se a seguir uma explicação mais detalhada em comparação com as leis empíricas (mais experimentais, mais baixas no nível de observação) e com as leis mentais (mais altas em âmbito de abstração).

De acordo com Mill, as leis da mente compõem a porção universal ou abstrata da filosofia da natureza humana. Todas as verdades da experiência comum que constituem um conhecimento prático da humanidade devem, na medida em que são verdades, ser resultados ou conseqüências destas leis da mente. Estas máximas familiares, quando coletadas a posteriori a partir da observação da vida são chamadas de leis empíricas.

Uma lei empírica é uma uniformidade (seja de sucessão ou de coexistência) que contém a verdade em todos os exemplos dentro dos limites de observação. Entretanto, não há nenhuma garantia de que estas leis possam assegurar a verdade para além destes limites de observação. Isto ocorre porque o conseqüente não é, na verdade, o efeito do antecedente, mas efeito de causas anteriores ainda não determinadas. Em outras palavras, uma lei empírica é uma generalização, que não contente em indagar sobre esta verdade, deve-se perguntar sobre as condições de sua verdade, sabendo que sua verdade não é absoluta, mas dependente de algumas condições gerais que precisam ser conhecidas.

As observações coletadas da experiência comum e concernentes aos assuntos humanos são, precisamente, desta natureza. Mesmo que sejam, universalmente, e, exatamente, verdadeiras dentro dos limites da experiência, o que de fato nunca ocorre, (porque é impossível enumerar todas as infinitas circunstâncias que atingem o fenômeno humano), ainda sim, elas não são as últimas leis da ação humana, elas não são os 
princípios da natureza humana (leis da mente), mas o resultado de tais princípios, sob as circunstâncias nas quais a humanidade se encontra exposta. Ou seja, Mill admite leis empíricas, mas que gera diferentes resultados conforme são expostas a diferentes circunstâncias. Quando o pregador diz apressadamente que todos os homens são mentirosos, ele enuncia que em alguns países e eras isto foi verificado por experiência. Contudo, mentir não é uma lei da natureza humana, mas antes uma lei empírica. Embora seja uma das conseqüências das leis da natureza humana que a mentira aconteça como um resultado natural, quando certas circunstâncias como a desconfiança e o medo operam sobre o indivíduo. Esta constitui uma lei empírica, entretanto, a lei empírica deriva de leis causais. Caso conheça-se as leis causais ou leis da natureza humana, têm-se os limites aos quais as leis empíricas estão submetidas. Enquanto não se tem uma lei empírica e as leis causais, permanece-se apenas no campo da observação incerta, não há nenhuma segurança em aplicá-la para além dos limites do tempo, lugar e circunstância, nas quais as observações foram feitas.

As reais verdades científicas, então, não são estas leis empíricas, mas as leis causais que explicam as leis empíricas. As leis empíricas de tal fenômeno, que dependem de causas conhecidas e nas quais uma teoria geral pode ser construída, não possuem nenhuma outra função na ciência além daquela de verificar as conclusões da teoria. As leis empíricas estão sob os limites da observação e apenas aproximam-se a generalizações.

A partir destas afirmações Mill ressaltará que as leis empíricas da natureza humana são meramente generalizações aproximadas. As leis universais são aquelas da formação do caráter. Este fato, entretanto, não é uma peculiaridade das ciências chamadas sociais. É apenas no ramo mais simples (mais exatos) da ciência que as leis empíricas são exatamente verdadeiras, e não em todos os casos. A astronomia, por exemplo, é a mais simples de todas as ciências e explica, no concreto, o curso real dos eventos naturais ${ }^{307}$. De acordo com Mill, as generalizações que podem ser coletadas da observação direta, mesmo as leis de Kepler, são meras aproximações. Os planetas, por exemplo, são ditos moverem-se em elipses exatas, mas não se movem desta forma. Então, mesmo na astronomia, a exatidão perfeita de leis empíricas não deve ser

${ }^{307}$ Mill, (1843), 1999,p. 61. 
procurada. Estas leis devem, ainda, ser menos exatas, em assuntos mais complexos de pesquisa como as ciências sociais.

Este mesmo exemplo, de acordo com Mill, mostra como é difícil obter universalidade destas leis. Para se ter a exata medida desta complexidade nas ciências sociais, basta supor que não há nenhum fato ou evento que atinja os seres humanos que não influencie de algum modo ou em algum grau sua história mental subseqüente. Além disso, se as circunstâncias de seres humanos diferentes são, também, extremante diferentes, não será surpreendente que poucas proposições possam ser feitas com respeito aos detalhes da conduta humana que sejam verdade para toda a humanidade.

Entretanto, sem decidir se estas leis etológicas da natureza mental humana são poucas ou muitas, é ao menos certo que elas são do tipo acima descrito. É certo que os estados mentais e as capacidades mentais e suscetibilidades são modificadas, tanto por um tempo ou permanentemente, por tudo que ocorre aos homens na vida. Considerando, entretanto, o quanto estas causas modificadoras diferem no caso de dois indivíduos, seria razoável esperar que as leis empíricas da mente humana ${ }^{308}$ (as generalizações que podem ser feitas com respeito aos sentimentos ou ações da humanidade sem referência às causas que as determinam) não seriam nada além de generalizações. Estas generalizações são a sabedoria comum da vida. Estas máximas podem ter alguma aplicação quando utilizadas em casos semelhantes, entretanto, quando aplicadas, por exemplo, a casos muito distintos tendem a falhar. As circunstâncias que influenciam a vida dos indivíduos diferem de nação para nação e de geração para geração, sendo que nenhuma destas diferenças pode ser desprezada na formação de um tipo diferente de caráter.

Ainda sim, considerando toda essa dificuldade de compreensão do caráter dos indivíduos, todos os modos de sentir e agir encontrados na humanidade possuem causas (leis etológicas) que os produzem e são nas proposições que assinalam estas causas que serão encontradas explicações das leis empíricas. Ou seja, as explicações das leis empíricas estão nas causas que são concernentes à natureza humana.

Conforme mencionado, a tese hedonista ressalta a busca pelo prazer e fuga da dor. Em outras palavras, o homem busca o prazer porque é agradável e não busca a dor porque é desagradável. Tal propensão pode ser considerada uma característica do caráter

${ }^{308}$ Mill, (1843), p.864 (edição liberty fund). 
humano, ou um fim do caráter humano (a busca pela felicidade) ao qual todos os outros motivos de ação submetem-se, ou são como partes desse motivo de ação, no sentido de que se associam à felicidade de alguma forma, ainda que inconscientemente (pelas leis da mente). Como é o caso do agir por hábito, o agir de acordo com as faculdades mais elevadas e a capacidade que o indivíduo tem de transformar-se ao longo do tempo. Conforme mencionado anteriormente, uma lei etológica que poderia ser extraída refere-se ao fato de que "a experiência tende a gerar cautela". Pode-se entender que tal lei causal de explicação do caráter humano constituiria uma forma agir (com cautela, desde que se tenha experiência), mas o agir com cautela é um meio para se atingir a felicidade, ou mesmo poderia ser uma parte da felicidade no sentido de que estaria em associação a ela (por meio da lei de associação). Outras leis etológicas poderiam ser extraídas, mas estariam sempre submetidas à tese principal hedonista. O método, de extração dessas leis é o método dedutivo indutivo (comparando as consequiências das deduções por verificação com as leis empíricas), será mais adiante mostrado que é o mesmo método utilizado nas ciências físicas. As leis etológicas uma vez extraídas são teoremas de uma ciência e podem ser convertidos em preceitos (preceitos são uma arte, assim denominadas por John Stuart Mill), sempre submetidos à tese hedonista.

Seres humanos não sentem e agem de modo semelhante nas mesmas circunstâncias, mas é possível determinar o que faz uma pessoa sentir e agir de uma dada forma, conforme as circunstâncias. Ou seja, quer-se descobrir como qualquer dada forma de agir tem sido explicada pelas leis gerais da etologia, quer-se explicar as leis empíricas pelas leis de formação do caráter. É por meio destas leis combinadas com os fatos que ocorrem para cada caso particular, que o todo do fenômeno da ação e do sentimento humano é produzido; é sobre elas que cada tentativa racional de construir a ciência da natureza humana deve proceder.

Mill afirma que as leis de formação do caráter não podem ser determinadas pela observação e experimento. Esta afirmação está plenamente de acordo com o texto On The Definition of Political Economy, pois neste texto também afirma-se não ser possível determinar as leis da mente ou da natureza humana por meio de experimento.

Para que se formule as leis da formação do caráter torna-se necessário determinar o melhor método de investigação ajustado para determinar estas leis. Os 
princípios lógicos que devem ser utilizados para construir o método das ciências sociais (incluindo uma ciência moral) devem ser os mesmos que são utilizados para investigar as leis dos outros fenômenos complexos. É evidente que tanto o caráter de qualquer indivíduo e o agregado das circunstâncias, por meio das quais aquele caráter foi formado, são fatos de uma ordem superior de complexidade do que outros assuntos científicos, pois envolvem mais circunstâncias que são mais variáveis.

Para estes casos, o método dedutivo, partindo de leis gerais (da mente) e verificando suas conseqüências, pela experiência específica é aplicado. Note que estas leis gerais, entretanto, são também auferidas por indução. Esta dedução é também descrita no texto On The Definition of Political Economy como sendo feita pelos homens teóricos da seguinte maneira:

"são chamados teóricos aqueles que objetivam abranger um campo mais vasto da experiência e tendo raciocinado (upwards) (também pela via da indução) de fatos particulares para um princípio geral, diferenciam-se dos primeiros, pois incluem um escopo muito maior, em suas teorias, do que a questão sob discussão. Após extraídos os princípios gerais, também por indução, os teóricos raciocinam (downwards) dos princípio gerais para uma variedade de conclusões específicas"'[Mill, 1824]

Há, apenas, duas maneiras nas quais as leis da natureza podem ser determinadas: a) dedutivamete (combinando a indução) e b) experimentalmente. Tendo em vista que se inclui sob a denominação de pesquisa experimental (método químico) a observação, bem como experimentos artificiais. Questiona-se, então, são as leis de formação de caráter suscetíveis de uma investigação satisfatória pelo método da experimentação? Mil, conforme afirma no texto On The Definition Of Political Economy, ressalta que não se pode obter as leis da formação do caráter de um indivíduo pelo método da experimentação, pois mesmo se fosse suposto um poder ilimitado de variar o experimento (o que não é possível em ciências sociais), uma condição mais essencial que 
teria que ser obtida seria a de garantir o poder de realizar qualquer dos experimentos cientificamente acurados ${ }^{309}$.

Os casos requeridos para a tentativa de realização de uma pesquisa diretamente experimental sob a formação do caráter corresponderiam a obter um número de seres humanos (hipoteticamente selecionados) para serem criados e educados desde a infância até a idade madura, sob condições controladas. Para que fosse realizado qualquer um destes experimentos com propriedade científica seria necessário conhecer e registrar todas as sensações e impressões destes indivíduos. Ora, seria não apenas moralmente absurdo efetuar tal experimento com seres humanos, como impossível fazer isto com sucesso, pois seria difícil que tal experimento fosse realizado com uma precisão aceitável. Circunstâncias, aparentemente, triviais, que enganariam a vigilância, poderiam deixar de lado uma série de impressões e associações que seriam suficientes para viciar o experimento artificial, moralmente condenável.

Sob esta impossibilidade de estudar as leis de formação do caráter por experimentos inventados propositadamente, permanece o recurso à simples observação. Portanto, Mill sustenta a tese, bastante razoável, de que é impossível realizar experimentos controlados em ciências sociais.

Entretanto, se é impossível determinar as circunstâncias que influenciam o caráter de um indivíduo com qualquer aproximação completa, mesmo quando o contorno destas circunstâncias é visível (controlável como no experimento imaginável), mais impossível é fazer isto quando os casos são removidos do controle, restando apenas a observação. No caso de observações, tentar-se-ia observar em qual estado de circunstâncias prévias o caráter é formado, quais qualidades mentais marcadas ou deficiências o indivíduo possuiria. Portanto, ressalta-se que não é possível determinar, por leis empíricas exatas o caráter de um indivíduo, mas apenas por leis empíricas que são generalizações aproximadas ${ }^{310}$, entretanto, mesmo estas observações não devem ser feitas visando determinar completamente, em qualquer caso dado, o caráter exato do

\footnotetext{
${ }^{309}$ Mill, (1843), p.866 (Liberty Fund).

${ }^{310}$ Mill, (1843), 1999, p. 62 "Elas constituem o saber comum da vida ordinária e, como tais, são inestimáveis, principalmente porque estão destinadas, na maioria das vezes, a ser aplicadas a casos não muito distintos daqueles a partir dos quais foram obtidos."
} 
indivíduo, mas apenas, observar em qual estado de circunstâncias prévias é notado que certas qualidades mentais marcadas ou deficiências existem neste caráter.

São tão numerosas e variadas as circunstâncias que formam o caráter individual que o que é obtido, mesmo depois da mais extensiva e acurada observação é, meramente, um resultado comparativo, por exemplo, o de uma amostra de franceses aleatória seriam encontradas mais pessoas com uma tendência mental e menos com a tendência contrária do que em um número igual de ingleses. Entretanto, quanto mais sutis as diferenças maior o número de circunstâncias que se deve adicionar para reduzir o acaso. Por isso é difícil emitir opinião indiscutível sobre o caráter de nações ${ }^{311}$.

Finalmente, se fosse possível obter por meio do experimento uma garantia mais satisfatória do que realmente pode estas leis, elas ainda seriam apenas leis empíricas. Elas mostrariam que haveria uma conexão entre o tipo de caráter formado e as circunstâncias do caso existente, mas não mostrariam o que esta conexão é, nem mostrariam quais as causas do efeito (quais são as leis que explicam o efeito, quais são as leis etológicas).

As leis empíricas seriam os resultados da causalidade, sendo resolvidas em leis gerais das causas, mas estas leis, como, por exemplo, o caráter de uma nação, mudam com a transformação das instituições. $\mathrm{O}$ mesmo ocorre em relação à diferença ente homens e mulheres, pois esta também tende a diminuir. Contudo, se as diferenças que se pensa observar entre franceses e ingleses ou entre homens e mulheres podem ser conectadas a leis mais gerais, se são tais que podem ser produzidas pelas diferenças de governos, costumes antigos e peculiaridades físicas nas duas nações e pelas diversidades de educação, ocupações, independência pessoal e privilégios pessoais, então, na verdade, a coincidência dos dois tipos de evidências justifica pensar que se raciocinou corretamente e é possível haver leis etológicas.

A observação embora não suficiente como prova serve para verificação. Tendo determinado não apenas as leis empíricas, mas as causas dela (um conjunto de circunstâncias combinadas a leis mentais deduzidas e verificadas pelas leis empíricas) pode-se julgar, sem dificuldade, o quanto podem ser esperadas que sejam permanentes, ou por quais circunstâncias poderiam ser modificadas ou destruídas. Com estas

${ }^{311}$ Mill, (1843), 1999, p. 65. 
considerações é possível provar não ser possível auferir leis do caráter e portanto da natureza humana, a partir de experimentos, não obstante demonstra ser possível utilizar a observação como verificação de causas desta mesma natureza. As leis da formação do caráter devem, por esta razão, ser estudadas dedutivamente de generalizações mais “altas". Sendo impossível obter proposições realmente acuradas com respeito à formação do caráter, a partir da observação e do experimento os pesquisadores são levados a examinar aquele que seria o mais perfeito modo de investigação e aquele que é um dos principais objetivos da filosofia, a saber: a formulação de seus experimentos, não a partir de fatos complexos, mas de fatos simples dos quais os fatos complexos são compostos e após determinar as leis das causas (leis etológicas que explicam as leis empíricas), então, considera-se se estas causas explicarão aquela seqüência do fenômeno complexo. Ou seja, efetua-se uma comparação ou verificação das causas com as generalizações efetuadas empiricamente.

As leis de formação do caráter são, em resumo, leis derivadas, resultantes de deduções de um conjunto de circunstâncias das leis mais altas (leis gerais da mente) ${ }^{312}$. É afirmado por Mill, portanto, que o caráter do indivíduo muda conforme a ação de circunstâncias sob as leis da mente de um indivíduo e esta é uma importante afirmação, para alguém que se pretendia um reformador como Mill, para alguém que acreditava que a partir da reforma e da educação seria possível modificar o caráter dos indivíduos.

Segundo esta definição a etologia é a ciência que corresponde à arte da educação, no mais amplo sentido do termo, incluindo a formação do caráter nacional ou coletivo, bem como do caráter individual ${ }^{313}$. Seria, na verdade, vão esperar que se possa conhecer tão acuradamente as circunstâncias de quaisquer casos dados, para estar-se apto a prever o caráter que poderia ser produzido em um caso particular. Entretanto, é possível lembrar que um grau de conhecimento com um menor poder de predição real é, freqüentemente, de muito valor prático. É suficiente que se saiba que certos meios têm a tendência a produzir um dado efeito e outros meios possuem a tendência de impedi-los. Quando as circunstâncias que influenciam um indivíduo ou uma nação estão sob controle, pode-se, por meio do conhecimento das tendências estar-se apto a moldar

\footnotetext{
${ }^{312}$ Mill, (1843), 869 (edição liberty fund).

${ }^{313}$ Ibid.
} 
aquelas circunstâncias de uma maneira muito mais favorável aos fins desejados, do que a forma que assumiriam sem o conhecimento desta tendência. Este é o limite do poder de moldar o caráter individual ou nacional, mas este limite é bastante amplo. É um limite dado pelas leis etológicas que são deduções das leis mentais mais altas, quando submetidas a um conjunto de circunstâncias. Conforme mencionado, estas leis são tendências hipotéticas, sendo que não é porque estas tendências podem ser frustradas que sejam menos verdadeiras.

Esta ciência da etologia pode ser chamada de ciência exata da natureza humana, mas suas verdades não são generalizações aproximadas, mas leis reais, de acordo com Mill ${ }^{314}$. É necessário à exatidão das proposições, entretanto, como em todos os casos do fenômeno complexo, que elas sejam hipotéticas apenas, e afirmem tendências e não fatos. Aqui remeto novamente ao texto On The Definition of Political Economy onde está expresso que leis das ciências sociais são leis hipotéticas ${ }^{315}$.

Elas não devem determinar que algo sempre, ou certamente ocorra, mas apenas qual será o efeito de uma dada causa. Por exemplo: são proposições científicas que a força de um corpo tenda a deixar um homem corajoso ou que a experiência tenda a dar sabedoria a um indivíduo. Estas proposições são determinadas apenas como tendências, mas não são menos universalmente verdadeiras porque estas tendências podem ser frustradas quando comparadas a fatos.

Não obstante ser ressaltado que as proposições ou leis causais etológicas sejam tendências que podem ser comparadas a fatos, é bastante difícil que a tese hedonista (que os homens buscam a felicidade e este é o único fim desejável estando os outros fins atrelados a estes) seja frustrada quando comparada a fatos. E isto não é contraditório com o fato dos outros homens terem outros fins imediatos ou mesmo passarem boa parte de sua vida não pensando na felicidade propriamente, pensando na associação que seus trabalhos, estudos, passeios, com a felicidade, que lhes proporcionam. Por isso, tem-se argumentado, nesta tese, que a natureza humana do indivíduo teórico de Mill é mais complexa quando comparada ao indivíduo teórico de

\footnotetext{
${ }^{314}$ Mill, (1843), 1999, p. 68.

${ }^{315}$ É importante notar que o conhecimento deixa de ser certo e verdadeiro como para Descartes no século XVII e meados do século XVIII e passa a ser conhecimento hipotético no século XIX como fica bem ressaltada nesta passagem em que afirmo, que as leis em ciências sociais não são menos reais por serem hipotéticas.
} 
Bentham, além da capacidade de sentir dor e prazer, ela é dotada da capacidade de agir por hábito, de faculdades mais elevadas, da capacidade que o indivíduo tem de transformar-se ao longo do tempo, apesar de serem características que derivem seu valor da tese hedonista. Estas características ou teoremas de uma ciência são convertidos em um princípio de utilidade, um preceito (arte), que ressalta que prazer deve ser buscado pelo seu valor em si e dor deve ser evitada, mas muito mais coisas precisam ser entendidas para que se compreenda a noção de prazer e dor. Esta frase, escrita na formulação do princípio, abre brecha para que o indivíduo possa agir guiado, não apenas por um único princípio, o que seria uma abstração bastante alta, relativamente à realidade e possa guiar-se por outros princípios ou princípios secundários, como regras morais derivadas do princípio primeiro, princípio de utilidade que também é derivado das outras características humanas que não apenas a tese hedonista, como o agir por hábito (que permite que o indivíduo não aja o tempo todo baseado em cálculos, quebrando as regras dos costumes a todo instante, permite que o indivíduo vá para o mundo com uma série de referências morais que são as regras morais secundárias, como o não matar, não roubar, apreciar a arte, etc), agir de acordo com faculdades mais elevadas que uma vez ativadas dão origem a prazeres de qualidade mais elevada, a prazeres que são somente humanos (como a leitura de um livro, a apreciação de uma música, a degustação de um vinho, entre outros) e a capacidade que o indivíduo tem de se transformar ao longo do tempo quer por sua escolha, quer por meio da mudança de circunstâncias a que ele está submetido, em função de sua felicidade também.

O homem tem, até certo ponto, poder para alterar seu caráter. Que o caráter seja, em última análise, formado para ele não é inconsistente com o fato de ser, em parte, formado por ele como um dos agentes intermediários. Seu caráter é formado por suas circunstâncias (incluindo-se, entre essas, sua organização particular), mas seu próprio desejo de moldá-lo de uma maneira particular é uma dessas circunstâncias e, de nenhuma forma, uma das menos influentes.(...) Se eles puderam nos colocar sob a influência de certas circunstâncias, nós, da mesma forma, podemos nos colocar sob a mesma influência de outras circunstâncias.” [Mill, (1843),1999, 38] 
É claro que a capacidade que o indivíduo tem de transformar seu caráter ao longo do tempo está conectada às escolhas que os indivíduos fazem, mas está limitada pelas circunstâncias que lhes são impostas, como por arranjos institucionais, sejam eles favoráveis ou desfavoráveis, a educação, a interação entre indivíduos, contextos históricos, etc. Quanto maior a margem de mobilidade em uma sociedade maior o controle sobre as circunstâncias que um indivíduo possui, quanto menor esta margem de mobilidade, provavelmente menor o controle sobre as circunstâncias.

Conforme mencionado no início deste tópico, os princípios da etologia são os axiomas médios (axiomata media) da ciência mental. Enquanto, por um lado, a psicologia é uma ciência da observação e do experimento, a etologia, conforme concebida por Mill, é dedutiva. A psicologia determina as leis simples da mente (as generalizações mais altas) e a etologia traça sua operação em meio a combinações complexas de circunstâncias. A formação do caráter do indivíduo se dará a partir de uma dedução da combinação das leis das mentes com as circunstâncias e verificação com as leis empíricas. Tais circunstâncias dependem de arranjos institucionais, da educação em seu sentido mais amplo, da interação com indivíduos, do contexto histórico e também das escolhas que indivíduos fazem em suas vidas.

Os princípios da etologia são, propriamente, os princípios do meio os axiomata media (como Bacon os elencaria) da ciência da mente, como distintos, por um lado, das leis empíricas resultantes da simples observações e por outro, distinguidos de generalizações mais altas, mais abstratas. Ou seja, estes princípios são os princípios do meio, porque estão entre as leis empíricas e as generalizações mais altas.

Bacon $^{316}$ observou, prudentemente, que os axiomas do meio de cada ciência constituem importante valor. As generalizações mais baixas, explicadas pelos princípios do meio (as leis etológicas explicam as leis empíricas) e resolvidas por meio destes são pouco acuradas como as leis empíricas (e não são causais), enquanto as leis mais gerais são gerais demais e abrangem poucas circunstâncias para dar suficiente informação sobre o que acontece nos casos particulares, onde as circunstâncias que influenciam são muito

\footnotetext{
${ }^{316}$ Bacon 1974, "Mas os axiomas tidos como supremos e mais gerais [...] são meramente conceituais ou abstratos e nada têm de sólido. Os médios são os axiomas verdadeiros, os sólidos e como que vivos, $e$ sobre os quais repousam os assuntos e a fortuna do gênero humano."
} 
numerosas. Mill ${ }^{317}$ ressalta ser quase impossível não concordar com a importância que Bacon deu aos princípios do meio para entender os fenômenos reais.

Da mesma forma, ainda que se trate de uma arte e não de uma ciência, tentar abranger toda a moralidade com apenas um princípio; o princípio de utilidade, seria, no campo prático, ser geral demais quanto a um preceito (é correto e deve-se buscar a felicidade), este princípio, o princípio de utilidade, realiza-se por meio de inúmeros subprincípios ou princípios secundários, em moralidade, pois assim, o indivíduo lança-se em sua vida prática, com regras morais pré-estabelecidas, embora tenham seu fundamento no princípio da utilidade e não violem a tese hedonista, buscando preservar a felicidade e de preferência a felicidade do maior número possível. A elaboração e constância destas regras morais secundárias são possíveis devido aos outros elementos presentes na natureza humana, como o agir por hábito, agir de acordo com faculdades mais elevadas e a capacidade que o indivíduo tem de transformar seu caráter.

Apesar de Bacon ter afirmado que os axiomas da etologia eram os axiomas do meio, Mill argumenta que Bacon estava totalmente equivocado em sua explicação com respeito à maneira pela qual os axiomas do meio eram auferidos, pois Bacon enuncia como uma regra universal que a indução deveria proceder dos princípios mais baixos aos princípios do meio e destes aos mais altos, nunca revertendo aquela ordem e, como resultado não deixando espaço para a descoberta de novos princípios através da dedução. De acordo com Mill a dedução é válida para descobrir leis gerais, por exemplo, as leis do movimento são utilizadas em conjunto com outras leis para explicar dedutivamente o fenômeno celestial. O erro dos antigos, de acordo com Mill, não está em utilizar o método dedutivo, em realizar as mais amplas generalizações primeiro, mas em fazê-las sem a ajuda ou garantia do método rigoroso indutivo e aplicar estas amplas generalizações desconsiderando uma importante parte do método dedutivo denominado verificação. Ou seja, a dedução deve ser realizada em conjunto com as regras da verificação.

Desta forma, a dedução é validada pela combinação de leis mais gerais que foram obtidas por indução com um conjunto de circunstâncias. A ciência da formação do caráter é uma ciência das causas. Este assunto é um daqueles entre os quais os cânones da

${ }^{317}$ Mill, (1843), 1999, p. 69 
indução, pelos quais as leis da causalidade são determinadas, podem ser rigorosamente aplicados. É, entretanto, tanto natural como aconselhável determinar, primeiro as causas mais simples que são necessariamente as mais gerais e depois deduzir os princípios do meio a partir destas leis gerais, mais simples obtidas por indução. Em outras palavras a Etologia, a ciência dedutiva, é um sistema de corolários da psicologia (leis da mente).

É importante não esquecer que a etologia refere-se às leis da mente, bem como as circunstâncias nas quais os indivíduos são expostos. Bacon diria que estas leis do meio deveriam também ser induzidas de boa parte dos casos empíricos, já Mill não concorda com esta observação, pois pensa que as leis do meio podem, perfeitamente, ser deduzidas destas leis mais gerais. A partir destas considerações é possível realizar uma caracterização da etologia.

Apesar da psicologia ter sido concebida e estudada como uma ciência, a Etologia ainda estaria em fase de criação. De acordo com Mill as leis empíricas destinadas a verificar as deduções dos princípios da etologia estavam sendo formadas em abundância por cada sucessiva época da humanidade, sendo que as premissas utilizadas para as deduções estavam suficientemente completas, excetuando-se o grau de incerteza que ainda existia para auferir estas causas ou premissas, bem como a extensão das diferenças naturais entre as mentes individuais e as circunstâncias físicas nas quais estas diferenças individuais de mentes podem depender (considerações estas que são de secundária importância quando se leva em conta a humanidade na média).

$\mathrm{O}$ autor ${ }^{318}$ pensa que os mais competentes juízes concordarão que as leis gerais dos diferentes elementos constituintes da natureza humana (leis da mente) estão suficientemente entendidas, para tornar possível a um pensador competente deduzir um particular tipo de caráter das leis da mente com uma considerável aproximação à certeza, para um dado conjunto de circunstâncias. Note que a natureza das circunstâncias tem um grande poder de modificar o caráter de um indivíduo. Isto será bastante importante para entender o método histórico de Mill, é importante para entender que o indivíduo teórico de Mill é um indivíduo dinâmico, que muda com o tempo. De acordo com o autor, a ciência da etologia fundada nas leis da psicologia é possível, embora, pouco tenha sido feito, e o que foi feito foi organizado não sistematicamente.

${ }^{318}$ Mil, 1843, p. 873. (Liberty Fund) 
O progresso desta importante ciência dependeria de um duplo processo: a) primeiro aquele de deduzir teoricamente as conseqüências etológicas de circunstâncias particulares de posição e compará-las com o resultado comum da experiência e b) segundo realizar a posição reversa, contrária, ampliando o estudo de vários tipos da natureza humana que podem ser achados no mundo conduzidos por pesquisadores capazes de analisar e registrar as circunstâncias que influenciam os tipos de natureza humana catalogados e que tenham conhecimento das leis etológicas, para explicarem as peculiaridades das circunstâncias que influenciam os caracteres (explicar o resíduo).

No que concerne à parte experimental (leis empíricas) ou a posteriori do processo de formação das leis etológicas, os materiais de análise estão sendo, frequentemente, acumulados pela observação da humanidade ${ }^{319}$. O maior problema da etologia é deduzir os requeridos princípios do meio que corresponde às causas de todas as qualidades nos seres humanos que são interessantes, tanto fatos a serem produzidos, a serem evitados ou meramente a serem entendidos. Os objetos devem ser determinados de leis gerais da mente combinadas com reais ou possíveis combinações de circunstâncias que são capazes de promover ou de prevenir a produção de determinadas qualidades nos seres humanos. Uma ciência que possui princípios do meio deste tipo, organizadas em ordem, não de causas, mas de efeitos que se deseja produzir ou prevenir, está preparada para ser a fundação da arte correspondente. Mill almejava que quando a etologia estivesse pronta, a educação prática seria a mera formação dos princípios em um sistema paralelo de preceitos (que seriam inclusos no que se denomina arte) e a adaptação destes princípios à soma do total das circunstâncias individuais que existem em cada caso particular.

Ou seja, assim como se converteu o teorema da tese hedonista em um preceito, o princípio de utilidade, mas que se reconheceu que a natureza humana do indivíduo teórico de Mill é muito mais complexa do que apenas sustentar a tese hedonista, como possuir a possibilidade de agir por hábito, agir baseado em faculdades mais elevadas que dão origem a prazeres mais elevados e levando em conta a capacidade que o indivíduo tem de transformar-se, ele é capaz de se utilizar de sua natureza mais complexa para converter os teoremas da ciência em preceitos responsáveis pela criação

${ }^{319}$ Mill, 1843, p. 873. 
de princípios secundários ou regras da moralidade. Em outras palavras, é porque é parte da natureza dos indivíduos elementos como o hábito, faculdades mais elevadas e a capacidade de modificar o caráter ao longo do tempo que princípios secundários (como não mate, não roube, aprecie a arte, seja corajoso, etc) podem ser formulados em associação com a felicidade, ainda que pareçam ser um fim em si.

Voltando a formulação da etologia como ciência, é necessário repetir, novamente, que como em todas as outras ciências dedutivas, a verificação a posteriori deve acompanhar a ciência dos princípios mais altos. A inferência dada pela teoria como ao tipo de caráter que seria formado por quaisquer dadas circunstâncias devem ser testadas pela experiência específica daquelas circunstâncias quando forem passíveis de serem obtidas e as conclusões da ciência como um todo devem passar por uma perpétua verificação e correção das considerações gerais oferecidas pela experiência comum, com respeito à natureza humana no tempo presente e pela história com respeito aos tempos passados. Há, portanto, uma importância da história como verificação das leis gerais da etologia. Isto será melhor visto quando for apresentado o método histórico ou dedutivo inverso.

As conclusões da teoria não podem ser confiáveis, ao menos que sejam confirmadas pela observação, nem as observações podem ser confirmadas ao menos que sejam associadas, remetidas à teoria pela dedução das leis da natureza humana e de uma análise próxima das circunstâncias de uma particular situação. É o acordo destes dois tipos de evidência, tomadas separadamente, a saber: a conciliação do raciocínio das leis da natureza humana, combinado a conjuntos de circunstância e deduzidos e comparados à experiência específica que forma a única suficiente base para os princípios de qualquer ciência e também para a Etologia.

Após considerações sobre a natureza humana sobre as leis causais que são o fundamento de todas as ciências, bem como considerações gerais sobre a etologia e explicam leis empíricas cabe a seguinte pergunta: os fenômenos sociais são um assunto de ciência? A resposta condizente com os textos de Mill seria: depois da ciência do homem individual vem a ciência do homem em sociedade, das ações das massas coletivas da humanidade e de vários fenômenos que constituem a vida social. É importante notar 
que Mill está estabelecendo uma anterioridade do indivíduo em relação à sociedade, isto é chamado em economia de individualismo metodológico.

É ressaltado no livro VI Capítulo VI do Sistema de Lógica ${ }^{320}$ que se a formação do caráter individual é um assunto complexo de estudo, o assunto referente à sociedade deve ser, ainda mais complexo porque o número de causas concorrentes, todas exercendo mais ou menos influência no efeito total, é ainda maior, por isso há um preconceito ainda maior em dar um caráter científico ao estudo de política e ao fenômeno da sociedade. A concepção de ciência política e social é, em geral, muito mal preparada para sua realização, embora o assunto político tenha obtido a maior atenção e tenha sido o tema de interessadas e sérias discussões. Ou seja, Mill retrata a dificuldade de se fazer ciência política e social em geral, a despeito de sua importância, a despeito de ser amplamente discutida e de interesse geral.

O autor reclama que em sua época o cultivo da política como ciência tinha sido abandonada a práticos, não estava sendo trazida para um ramo da pesquisa especulativa (ou ramo da ciência), mas apenas estava sendo considerada com respeito às exigências diárias práticas. Da mesma forma que a política estava sendo cultivada apenas como um ramo da prática, ocorreu, em tempos passados, o mesmo com a prática médica, pois começou a ser cultivada antes da fisiologia ou história natural. As únicas questões examinadas foram qual dieta deveria ser dada a alguém e qual remédio iria curar alguma dada doença, sem nenhuma pesquisa prévia sistemática sobre as leis da nutrição e sobre as leis da ação saudável e mórbida de diferentes organismos. As questões em política são similares: é uma tal ordenação ou uma tal forma de governo benéfica ou não, para alguma comunidade particular?

Sem uma pesquisa prévia sobre as condições gerais por meio das quais a operação das medidas legislativas ou os efeitos produzidos por formas de governo são determinados não é possível responder a esta pergunta. Ou seja, Mill ressalta, mais uma vez que a ciência deve preceder a arte (preceitos).

Mill $^{321}$ descreve que a filosofia da sociedade tinha feito pouco progresso até aquele momento, ela deveria conter poucas proposições gerais, mas suficientemente

\footnotetext{
${ }^{320}$ Mill, (1843), p. 873 (edição liberty fund).

${ }^{321}$ Mil ,(1843), p. 875 (edição liberty fund).
} 
precisas e certas, para que os pesquisadores reconhecessem nestas proposições um caráter científico. Embora a noção vulgar englobe a idéia de que toda pretensão de estabelecer verdades gerais em política e sociedade constitui charlatanismo, que nenhuma universalidade e nenhuma certeza são determináveis em tais assuntos, isto não deve ser levado em consideração.

Esta visão é parcialmente desculpada, pois o caráter das políticas filosóficas tem se esforçado não em determinar proposições universais, mas tem construído preceitos universais, preceitos estes que se pretende que sejam aplicados a todos os casos, o que Mill ressalta ser ridículo, pois seria como dizer que um remédio pode curar todas as doenças. Mais uma vez Mill está advertindo que o que tem sido feito em política é arte e não ciência e uma arte deve estar baseada em uma ciência e não o contrário.

O fenômeno da sociedade é tal que deve não apenas ser completamente dependente de causas conhecidas, mas o modo de ação de todas aquelas causas devem ser redutíveis a leis simples e ainda dois casos não devem admitir serem tratados da mesma forma, pois a experiência específica deve constituir um modo de verificação. Tão grande deve ser a variedade de circunstâncias nas quais os resultados dependem, em casos diferentes, que a arte não pode ter um único preceito para dar. Embora, em uma tão complicada classe de assuntos seja impossível estabelecer máximas ou preceitos de aplicação universal, não se segue que o fenômeno não obedeça a leis universais.

Após afirmado que os fenômenos sociais são assunto de ciência, é possível indagar de qual natureza a ciência social deve ser. De acordo com o autor, todos os fenômenos da sociedade são fenômenos da natureza humana gerados pela ação de circunstâncias externas sobre a totalidade de seres humanos. É importante notar a importância que Mill dá às circunstâncias como influenciando totalmente os fenômenos, como agindo sobre a natureza humana. A influência das circunstâncias sobre os caracteres humanos é fundamental, pois as circunstâncias podem ser modificadas conforme os arranjos institucionais, demonstrando que o indivíduo teórico de Mill possui uma natureza dinâmica que se modifica com o tempo.

"A variedade de circunstâncias de que dependem os resultados em diferentes casos podem parecer tão vasta que a arte não pode fornecer um único preceito geral, exceto o 
de estar atento às circunstâncias do caso particular $e$ adaptar nossas medidas aos efeitos que, de acordo com os princípios da ciência, resultam dessas circunstâncias." [Mill, (1843), 1999, p.75].

Se, entretanto, o fenômeno do pensamento humano, sentimento e ação são assuntos de leis fixadas (leis da mente), os fenômenos da sociedade conformam suas conseqüências a estas leis fixadas, mostrando que a sociedade é subordinada, em última instância às leis dos indivíduos.

"Todos os fenômenos da sociedade são fenômenos da natureza humana, gerados pela ação de circunstâncias externas sobre massas de seres humanos: se, portanto, os fenômenos do pensamento, do sentimento e da ação humana estão sujeitos a leis fixas, os fenômenos da sociedade só podem se conformar a leis fixas, que são conseqüencias das precedentes.” [Mill, (1843), 1999, p.75].

No entanto, de acordo com Mill, não há nenhuma esperança de que estas leis possam ser previstas pela história da sociedade por centenas de anos futuros. Entretanto, a diferença de certeza, por exemplo, em relação à astronomia, não está nas leis, mas está nos dados aos quais estas leis são aplicáveis.

Em astronomia, as causas que influenciam o resultado são poucas e mudam pouco em relação às leis conhecidas. $O$ que são estes resultados que podem ser determinados agora é o que podem ser determinados em qualquer época de um futuro distante. Os dados em astronomia são, portanto, tão certos como as leis.

Com relação à sociedade, ao contrário, as circunstâncias que influenciam a condição e o progresso da sociedade são inumeráveis e mudam permanentemente e embora elas mudem em obediência às causas e, portanto, às leis, a multidão das causas é tão grande que desafia os poderes humanos limitados de cálculo.

Entretanto, uma quantidade de conhecimento insuficiente para predição pode ser valiosa para orientação. A ciência da sociedade teria atingido um ponto muito alto de perfeição, se permitisse, em um estado dado da condição social, entender por meio de quais causas, os efeitos aconteceram e, principalmente prever o que ocorrerá e por meio de quais meios quaisquer um daqueles efeitos devem ser prevenidos, 
modificados ou acelerados ou diferentes classes de efeitos poderiam ser induzidos. Não é ilusório que se tente determinar leis gerais, capazes de prever efeitos para países ou tempos. Ou seja, Mill afirma explicitamente que leis científicas gerais para a sociedade podem ser atingidas em ciências sociais, embora seu fenômeno seja complexo.

Em relação aos métodos a serem aplicados em ciências sociais, a partir do exposto até agora, pode-se dizer, que embora explicitado no início do capítulo, procedese aqui a uma dedução acompanhando de maneira mais ou menos aproximada a ordem de justificação $^{322}$ destas leis pelo autor. Portanto, a partir de uma análise de como deve proceder-se para efetuar a leis etológicas, tem-se pistas de como deve-se proceder para compor as ciências sociais. Sabe-se que Mill não desconsidera as leis da natureza humana para entender o fenômeno social, nem tão pouco desconsidera as leis empíricas para entender tal fenômeno. Ou seja, o autor leva em conta leis da mente como as leis mais gerais, leva em conta leis da etologia ou formação do caráter dos indivíduos (como princípios do meio) e leva em conta as circunstâncias ou observações que agem modificando estas leis gerais para cada indivíduo, bem como considera as modificações históricas, que ocorrem de geração para geração. O método a ser utilizado em ciências sociais é o método físico dedutivo por composição de causas e verificação com leis empíricas (e indutivo quando se pensa a descoberta das leis da mente), este método é utilizado em todas as ciências sociais, apenas em algumas ciências sociais será utilizado o método dedutivo inverso. Todas as ciências sociais emprestarão o método da física (dedutivo indutivo, por composição de causas (que podem inclusive ser contraditórias) e por verificação com a experiência), a saber: a ciência política, ciência histórica, a etologia política , assim como a etologia e a ciência que embasa a moral.

Serão descritos alguns dos métodos que não devem ser aplicados em ciências sociais, maneiras erradas de filosofar ou pensar a sociedade e o governo. Estes métodos errados podem ser nomeados métodos experimentais ou químicos e modo geométrico ou abstrato. Os métodos corretos de se pensar em ciências sociais (e isto inclui a moral que será descrita como uma arte, um conjunto de regras e preceitos e não uma ciência) serão os métodos dedutivos e dedutivos inversos, levando em conta a história e relações com outros indivíduos. É importante ter em mente que o método

\footnotetext{
${ }^{322}$ Chiappin, notas de aula.
} 
geométrico também é dedutivo, mas ele não permite a composição de causas (muitas vezes contraditórias) mantendo-se muito distante da realidade para explicar o fenômeno. Além disso, não ajusta suas conclusões a leis empíricas como prescreve o método físico (a utilização da verificação).

É importante ressaltar que esta ciência da etologia ou leis etológicas leva em conta períodos em que as causas são muitas, mas são tomadas como estáticas. Há períodos que estas causas são dinâmicas, porque por decorrência em melhorias de arranjos sociais, etc, os indivíduos estão aprimorando seu caráter. Talvez, neste momento as causas do caráter humano tornem-se mais difíceis de serem captadas e é neste período mesmo que se torna necessário a utilização do método inverso.

\section{O método químico, ou método experimental em Ciência Social}

É afirmação desta tese que os homens em estado de sociedade são ainda homens (ou seja, carregam sua natureza humana) ${ }^{323}$, para Mill, ou seja suas ações e paixões obedecem às leis da natureza humana individual. Quando reunidos em sociedade, os homens não são transformados em outra coisa, em outro tipo de substância, como o hidrogênio e o oxigênio quando reunidos em certa quantidade transformam-se em água. Portanto, os seres humanos em sociedade conservam suas propriedades individuais, a saber: as leis da mente, a tese hedonista fundamental a qual as outras características humanas subordinam-se como faculdades mais elevadas, hábito e capacidade de transformar-se ao longo do tempo (o indivíduo tem uma característica dinâmica, em seu próprio modelo). No fenômeno social a composição de causas é a lei universal, assim como se dá com a lei da gravitação. Portanto, para um dado fenômeno social, diversas circunstâncias agem sobre a natureza humana para gerar tal fenômeno.

Os partidários da corrente de pensamento que se utiliza do método químico negligenciam os componentes da natureza humana em questões sociais e políticas, como se estes não influenciassem estes assuntos, exigindo, em todos os casos, uma experiência específica para tratar de tais temas, entretanto, a experiência específica é impossível em

\footnotetext{
${ }^{323}$ Daqui pode-se deduzir que a tese ontológica de que o que existe para análise política, de acordo com Mill, é o homem. Tese ontológica que concorda com Bentham.
} 
ciências sociais (restando apenas a observação), pois é impossível controlar experimentos nestas ciências e ainda que fosse possível imaginar alguns casos em que a experiência específica fosse aplicada (como o método da diferença e do acordo) ainda assim não seriam passíveis de serem aplicados em ciências sociais, uma vez que esta é uma ciência em que o fenômeno depende de uma multiplicidade de causas e não de apenas uma.

Ao adotar o método químico de recorrência direta a experiência específica, os partidários desta corrente julgam que estariam seguindo os ensinamentos de Bacon e estariam longe de adversários metafísicos. Entretanto, o que não sabem é que ao adotar métodos puramente experimentais aufeririam argumentos que não seriam universalmente válidos em nenhuma época em ciências sociais, pois ao invés de tentar erigir uma ciência tomam por ciência o senso comum.

Supondo o investigador familiarizado com as verdadeiras condições da investigação experimental e competente no que diz respeito à habilidade para realizá-las, na medida em que poderia ser realizada, ele saberia dos fatos históricos tudo o que a mera erudição poderia ensinar, tudo o que poderia ser provado pelo testemunho sem o auxílio de qualquer teoria (sem o auxílio às leis da natureza humana) e, se esses simples fatos, devidamente comparados, poderiam satisfazer as condições de uma indução real, poderse-ia dizer que ele estaria qualificado para a tarefa. Entretanto, semelhante tentativa não poderia ter a menor possibilidade de êxito, pois desconsidera as leis da natureza humana. É impossível entender as causas do fenômeno, sem obter por dedução as leis de natureza humana submetidas às circunstâncias presentes. A experiência serve apenas como material de verificação. Com tudo isto, o que se quer expressar é que método químico é impossível em ciências sociais, pois experimentos simulados ou controlados são impossíveis nestas ciências, sendo impraticável isolar as causas dos fenômenos em casos concretos da sociedade.

Além disso, é impossível aplicar o método da diferença em ciências sociais, pois não se pode determinar as causas de efeitos pela comparação de casos iguais (com apenas alguma característica diferente, a saber: a que se pretende entender, então isto 
seria um experimentum crucis $^{324}$ ), pois estes casos iguais, diferindo apenas em uma característica, não existem em ciências sociais.

$\mathrm{Na}$ falta do método direto da diferença poder-se-ia tentar aplicar o método indireto da diferença. Este método, em lugar de tentar comparar dois casos que não diferem em nada a não ser na presença ou ausência de uma dada circunstância, compara dois casos, numa das quais os casos concordam apenas na presença de uma circunstância e, na outra, apenas na ausência desta circunstância. Este método também é inconclusivo, pois, por exemplo, também não se encontra dois exemplos, em que se discorda de tudo e concorda-se apenas na presença de uma circunstância ou na ausência de uma circunstância. A comparação poderia ser efetuada entre duas nações.

E mesmo que fosse possível encontrar tais casos na realidade, a explicação de apenas uma causa gerando o todo de um fenômeno social (como pretende-se isolar no método químico) poderia ser considerada absurda, pois o fenômeno social é causado por inúmeras causas que frequentemente influenciam umas às outras, sendo a composição de causas a melhor explicação para a causalidade do fenômeno social.

1. Não é possível realizar experimentos nas ciências sociais.

Conforme explicitado anteriormente, não é possível realizar experimentos controlados em ciências sociais, além disso, pode-se dizer que tais experimentos seriam moralmente condenáveis. Contudo, mesmo que fosse possível efetuar tais experimentos, é possível afirmar que estariam em enorme desvantagem em relação aos experimentos químicos, pois os fatos sociais estão em constante mudança, sendo que muitas circunstâncias se modificariam, antes que se pudesse determinar o resultado do experimento. Pode-se apenas observar as experiências produzidas pelas interações sociais. Entretanto, esta observação, quando se desconsidera os componentes da natureza humana obtidos por deduções não explica o comportamento e mesmo o caráter dos indivíduos, pois conforme foi afirmado, os indivíduos não deixam de ser o que são

\footnotetext{
${ }^{324}$ Os experimentos crucis são assim definidos por Bacon: "não se dirigem a qualquer obra, mas à revelação de alguma causa. Assim, qualquer que seja o caso, satisfazem o intento e assim resolvem a questão".
} 
quando colocados em sociedade, embora possam modificar características de seu caráter que dependem das circunstâncias .

2. O Método da diferença é inaplicável

O método da diferença é o método experimental no qual é preciso encontrar dois casos que concordem em todos os detalhes exceto naquele que é objeto de investigação, por isso é chamado método da diferença, pois quer diferença em relação ao detalhe que se quer entender. Um bom exemplo sobre o qual pode ser aplicado o método da diferença diz respeito a duas nações. Caso seja possível encontrar duas nações semelhantes em todas as vantagens e desvantagens naturais, cujos povos se assemelham em todas as qualidades físicas e morais, cujos hábitos, opiniões, leis e instituições são as mesmas em todos os aspectos, exceto que uma delas tem uma tarifa mais protecionista ou interfere mais na liberdade de indústria; se ficar constatado que uma dessas nações é rica e a outra é pobre, ou uma é mais rica que a outra, então isso constituiráa ${ }^{325}$ um experimentum crucis - uma prova pela experiência que permite decidir qual dos dois sistemas é mais favorável às riquezas nacionais. Entretanto, supor que duas nações concordem em todas as características e divirjam em apenas uma é simplesmente absurda. Elas são efeitos de causas preexistentes. Caso duas nações tenham diferenças em uma questão de suas instituições, isto advém de diferenças em suas opiniões, hábitos e tendências que geram diferenças capazes de interferir não apenas na prosperidade industrial da nação, bem como em qualquer característica sua. Desta forma, é impossível satisfazer as condições da experiência específica em ciências sociais.

3. O método de acordo e de variações concomitantes são ditos inconclusivos na ciência social.

Uma vez feita a análise do método da diferença e provado que este método não se aplica às ciências sociais, analisa-se o método da concordância, apenas para também provar que não se aplica às ciências sociais, uma vez que não admite a

${ }^{325}$ Mill, (1843), 1999, p. 80. 
pluralidade de causas gerando o fenômeno e o método das ciências sociais é exatamente o método da pluralidade de causas como geradoras do fenômeno.

O método da concordância é aquele no qual dois casos discordam em todas as circunstâncias e concordam em apenas uma. Ainda seguindo o exemplo de duas nações, supondo que estas duas nações não concordam em nenhuma circunstância com exceção de que ambas possuem um sistema restritivo e são prósperas, não seria razoável supor que o sistema restritivo (antecedente) causou prosperidade (conseqüente), dado que no caso dos sistemas políticos uma única causa nunca é a responsável pela explicação de um fenômeno. Todos os assuntos de interesse ${ }^{326}$ de uma nação que causam a segurança, a riqueza, a liberdade, o bom governo, a moralidade pública, a cultura geral de seus homens são infinitamente numerosos acessíveis apenas à observação direta não sendo possíveis de serem controlados quer seja por experimento químico, quer seja pelo método da diferença (químico) quer seja pelo método da concordância. Há inúmeras causas que podem cooperar para a produção destes fenômenos, portanto, ainda que seja possível imaginar a situação absurda de que haja duas nações com tais características (diferentes em tudo, iguais apenas em uma característica) ainda assim essa concordância em uma característica não poderia ser a causa de um fenômeno social, pois fenômenos sociais são causados por inúmeras causas. Logo o método da concordância é inconclusivo em ciências sociais. O mesmo ocorre para as variações concomitantes. O método das variações concomitantes consiste em explicar cada efeito por uma só causa, por exemplo: como se a riqueza dependesse de uma causa, como se a paz dependesse de uma causa, como se uma terceira causa tornasse as pessoas virtuosas, uma quarta causa tornasse as pessoas inteligentes. Contudo, os fenômenos sociais são afetados por inúmeras causas, sendo que estes também podem afetar outros fenômenos sociais, vir a ser causa desses.

Existe outro método dentro do método químico denominado método do resíduo. Com a utilização deste método para explicar o fenômeno social subtraem-se todas as causas menos uma, contudo muitas causas cooperam para a produção de um efeito em ciência política, conforme mencionado. Portanto, esse método também é inconclusivo. Tal método tem como pressuposição que os fenômenos das causas sociais sejam conhecidos pela experiência específica, mas isto é impossível, porque a

${ }^{326}$ Mill, (1843) ,p. 884 (edição liberty fund). 
experiência específica é impossível em ciências sociais, é preciso que o conhecimento dos fenômenos seja obtido pela dedução a partir de princípios da natureza humana, conforme mencionado a experiência é utilizada apenas para verificação das conclusões deduzidas ou para explicar o erro decorrente. Entretanto, se é possível recorrer à natureza humana para que se estabeleçam algumas verdades políticas, isto é passível de ser feito para todas as verdades.

"Mas se podemos recorrer aos princípios da natureza humana para o estabelecimento de algumas verdades políticas, podemos fazê-los para todas.” [Mill, 1999, p. 8384]

3.6 O método geométrico ou abstrato

\section{Características gerais}

O método químico discutido no tópico anterior é utilizado, principalmente, por pessoas não habituadas a fazer ciência social, mas antes por pessoas que se utilizam do senso comum para justificar suas práticas em política.

Ao contrário do método químico, o método geométrico é utilizado por mentes estudiosas, em suma por verdadeiros cientistas, mas também é considerado errôneo por Mill. Os partidários do método geométrico associam a dedução à geometria, como se apenas a geometria utilizasse a dedução (sabe-se que a mecânica com a composição de forças, dinâmica, também utiliza a dedução) e aí incidem em erro porque a geometria parte de poucos axiomas ou poucas causas para explicar um fenômeno complexo como o social, em outras palavras, aqueles que empregam o método geométrico em ciências sociais confundem dedução com geometria e pecam por um excesso de abstração; explicam um fenômeno complexo a partir de poucas ou às vezes uma causa. Em mecânica é possível ainda que forças conflitantes ajam umas sobre as outras modificando-se mutuamente. Em geometria não há algo similar, ela não leva em conta efeitos de causas contrárias que agem para determinar o fenômeno. O que é provado verdadeiro a partir de um teorema geométrico é verdadeiro como se nenhum 
outro princípio geométrico existisse, não podendo ser alterado por outro princípio geométrico. O que é uma vez verdade é verdade em todos os casos. No caso do modelo de indivíduo teórico de Mill e mesmo das regras morais de Mill conforme se verá adiante, pode-se dizer que o indivíduo teórico de Mill está sujeito a constantes mudanças porque há um componente que o afeta constantemente denominado circunstâncias, embora tais circunstâncias sejam reguladas pelas leis da natureza humana (a saber: leis da mente, tese hedonista ou busca pelo prazer e fuga da dor a qual outros elementos derivam seu valor como faculdades mais elevadas, capacidade de agir por hábito, capacidade de modificar seu caráter ao longo do tempo).

Voltando à diferença entre a mecânica e a geometria, pode-se dizer que a primeira seria muito similar à segunda se cada movimento fosse resultado de apenas uma força, contudo, diferentemente da geometria é o resultado de um conflito de forças. Em geometria parece que o fenômeno social é o resultado de uma única força, de uma única propriedade da natureza humana, sem conflito e influência de outras propriedades.

Portanto, com relação ao caráter do fenômeno social, não há nenhum destes fenômenos complexos em que inumeráveis forças não exerçam influência, que não dependam de inúmeras causas. Depreende-se do acima exposto, então, que ao ser empregado o modelo geométrico, como método de raciocínio, tem-se deduzido erroneamente a maneira como os fenômenos da sociedade são produzidos, pois tal fenômeno social depende de inúmeras causas, inclusive conflitantes.

2. Exemplos do método geométrico

Nos exemplos de método geométrico Mill inclui dois tipos; o primeiro diz respeito àquele que não permite nenhuma modificação na lei do fato social por outra lei, partem de causas fixas e por dedução atingem conclusões (não usam a composições de causas da mecânica para explicar o complexo fenômeno social, conforme mencionado acima). O segundo tipo de método geométrico incorre em um erro ainda mais grave que concerne em basear teorias políticas em preceitos, ou o que é denominado cometer o erro de tratar uma arte como se fosse uma ciência e a partir da própria arte deduzir outros 
preceitos (arte), este é o caso daqueles que prescrevem o contrato social ou qualquer outra obrigação original e baseados nesta prescrição a aplica a casos particulares ${ }^{327}$.

Como exemplo de autor que adota o segundo tipo de método está Hobbes. Segundo Mill, ao assumir que os homens saem do estado de natureza e firmam um estado civil pelo medo e, além disso, mantêm-se no estado civil por meio de um pacto ou de um contrato, Hobbes ${ }^{328}$ comete um sofisma duplo, porque, primeiro passa da ficção ao fato e segundo porque assume um preceito como a base de uma teoria. Ora, sabe-se que toda regra de conduta deve estar fundada, baseada em uma teoria. Mais uma vez reforça-se a importância de fundar uma arte sobre uma ciência e não o contrário.

Mill também coloca a filosofia do interesse da escola de Bentham na classe daquelas escolas que utilizam o método geométrico, mas que cometem erros não por considerar a ciência fundada na arte, mas por não considerar leis contrárias às leis gerais como constituintes do fenômeno complexo social. Bentham sabia que os preceitos deveriam estar ancorados nas leis de natureza humana e que a aplicação da dedução deveria ocorrer sobre a ciência (as leis de natureza e não sobre os preceitos) não sobre a arte. $^{329}$.

$\mathrm{O}$ erro de Bentham, portanto, não foi fundar uma ciência sobre a arte e realizar deduções a partir de preceitos, como Mill aponta que foi o caso de Hobbes, o erro de Bentham estaria no fato de explicar o complexo fenômeno social a partir de uma única causa, conforme mencionado anteriormente, isto seria, também, incorrer em grave erro para Mill. Segundo este autor, Bentham teria nomeado a tudo que uma pessoa gosta de interesse. A proposição de Bentham deveria ser entendida, então, como significando que as ações dos homens são sempre determinadas por seus desejos privados.

Esta proposição não pode ser universalmente verdadeira por ser tão absoluta, de acordo com Mill, por dois motivos, a saber: a) primeiro porque os seres humanos não são conduzidos, em todos os seus atos pelos seus interesses privados e b) porque em política, o interesse não está na conduta de pessoas individuais, mas na conduta de um conjunto de pessoas. Então a assertiva deveria ser limitada ao seguinte: qualquer sucessão de pessoas ou maioria de qualquer corpo de pessoas será conduzida, no

\footnotetext{
${ }^{327}$ Mill, (1843), p. 887. (edição liberty fund).

${ }^{328}$ Obviamente esta é a opinião de Mill sobre Hobbes.

${ }^{329}$ Mill, (1843), 1999, p. 88
} 
todo de sua conduta, por interesses pessoais. Esta afirmação parece uma reafirmação do princípio de Bentham, conforme mostrado no capítulo I.

"Tomando então a doutrina neste sentido, apresenta-se, no limite, uma objeção que poderia ser considerada fatal, a saber, a de que uma proposição tão absoluta está longe de ser universalmente verdadeira. Os seres humanos não são governados em todas as suas ações, por seus interesses materiais" [Mill, 1999, p. 88].

Mill ressalta que a teoria de Bentham acerta ao expressar que as ações da humanidade são governadas, principalmente, pelos interesses próprios, mas isto não significa que não haja outros elementos auxiliares que possam explicar as ações dos indivíduos. O fato de Mill assumir que na maioria dos casos os agentes buscam maximizar seu prazer e minimizar suas dores ou agir conforme seus interesses próprios concorda com a tese hedonista sustentada por esta tese de que tudo deriva seu valor do prazer e da dor e isto também está de acordo com a teoria de Bentham, mas muitos elementos diferenciam o indivíduo teórico de Mill relativamente ao indivíduo teórico de Bentham, como o fato deste indivíduo possuir uma natureza humana mais complexa, com leis da mente (lógicas) e outras características que derivam seu valor da tese hedonista como o agir por hábito (além de poupar tempo no momento da ação do indivíduo, gera constância moral às ações e permite a formulação de princípios secundários de ação no campo moral, conforme será visto, como regras morais; não matarás, não roubarás, etc), faculdades mais elevadas relativamente a faculdades menos elevadas que também derivam seu valor do prazer que podem proporcionar, mas desta vez da qualidade ou do tipo de prazer que podem proporcionar ao agente moral (uma vez ativadas o indivíduo não troca tais prazeres mais elevados por prazeres menos elevados) e finalmente a capacidade que o indivíduo possui de desenvolver-se ao logo do tempo, a capacidade dinâmica que o indivíduo possui de transformar-se ao longo do tempo, de modificar seu caráter ao longo do tempo, uma vez que o caráter do indivíduo está submetido às mais diversas circunstâncias.

Sob a ótica de Mill, Bentham ressalta que os únicos interesses para fazer com que os governadores governem conforme os interesses do governado são aqueles 
que estejam de acordo com os interesses privados. Esta é uma proposição de Bentham sobre os homens do governo segundo a qual acrescenta-se uma terceira que enuncia que tais homens nunca possuem interesses idênticos aos dos governados, por serem autointeressados, por isso necessitam de um sistema coercitivo que mantenha o medo de perderem o poder como estímulo para fazer coincidir seus interesses com o interesse de todos.

Bentham constrói primeiro uma teoria da ação humana baseado em uma premissa, a saber: a de que todo indivíduo ao agir é auto-interessado (busca maximizar seu prazer e minimizar sua dor). Para construir uma teoria de governo ${ }^{330}$ utiliza o mesmo princípio da primeira premissa construindo a primeira premissa política de que as ações dos legisladores são determinadas apenas pelos interesses próprios, sendo que a decorrência desta primeira premissa política é uma segunda premissa política de que o senso do governante produz um senso de identidade para com o governado também por interesse de manter-se no poder.

De acordo com Mill, nenhuma dessas proposições é verdadeira dado que há muitas outras causas que explicam as ações dos governantes, além do interesse próprio, embora o próprio Mill assuma que esta é a principal.

Mill não quer substituir os interesses pessoais como geradores da ação pelo sentimento de filantropia, de dever, embora eles influenciem muitos homens do governo em algum grau e vários homens do governo em amplo grau, mas o autor ressalta que não é verdade que as ações dos indivíduos que exercem os poderes do governo são totalmente influenciadas pelo interesse individual e esta suposição por mais que possa parecer restrita em comparação a Bentham ocorre porque advém da divergência de natureza humana que Mill está definindo, que ocasiona uma diferença em seu princípio de utilidade e como decorrência deve, necessariamente, gerar uma diferença em qualquer teoria política que venha a ser de Mill relativamente à de Bentham, bem como uma ciência que embase a moral e é, precisamente pelo fato da natureza humana do indivíduo teórico de Mill ser mais complexa relativamente ao indivíduo teórico de Bentham que deriva um princípio de utilidade mais complexo que abre espaço para a formulação de princípios secundários ou uma maior quantidade de regras morais (pois é o princípio de

\footnotetext{
${ }^{330}$ Bentham, Constitutional Code, 1817.
} 
utilidade que determina se o indivíduo será um indivíduo calculador e fará cálculos a todo instante questionando a moralidade dos costumes a todo momento e, portanto, não dando nenhum espaço para a formulação de uma moral propriamente dita, ou o princípio de utilidade, no caso de Mill, quando elenca que muito mais coisas precisam ser ditas para entender o significado de prazer e dor, derivado da natureza humana mais complexa do indivíduo teórico de Mill, abre caminho para a formulação de princípios secundários, regras morais que o indivíduo segue por hábito, como não matarás, não roubarás ou seja corajoso). Desta forma, Mill insiste no que é verdade para todos os legisladores: que o caráter e o curso de suas ações são amplamente influenciados (além do cálculo pessoal ou interesse próprio) por sentimentos habituais ${ }^{331}$ que são os modos gerais de pensar e agir $^{332}$, que prevalecem em toda parte da comunidade, da qual eles são membros, bem como por sentimentos, hábitos e modos de pensar que caracterizam uma classe particular naquela comunidade a qual pertencem; o hábito faz parte da natureza humana e não exige que o agente faça cálculos a todos os instantes no momento da ação, bem como ocasiona constância ao agir moral. De acordo com Mill, as pessoas terão dificuldade de entender ou decifrar os sistemas de conduta que não levem em conta as caracterizações da natureza humana mais completas (que considerem não apenas a busca pelo prazer e fuga da dor, ou maximização da felicidade embora estes sejam os elementos principais do agir individual ou coletivo, mas que levem em conta na consideração de natureza humana as leis da mente, o agir por hábito, faculdades mais elevadas que dão origem a prazeres mais elevados e a capacidade do indivíduo de se transformar ao longo do tempo). E tudo isto não pode ser explicado pelo método geométrico de Bentham, uma vez que esse autor tenta elucidar toda a moralidade e seu sistema de governo a partir de apenas uma causa, a saber: o interesse privado.

Em ciência moral (base para uma moralidade), assim como em teoria política Mill ressalta que os homens do governo são influenciados por outras causas que não o auto-interesse como máximas e tradições que descendem de outros homens do governo. Os homens do governo podem agir de acordo com essas máximas e tradições que vem sendo firmadas durante longos períodos, mesmo que isto não venha de encontro

\footnotetext{
${ }^{331}$ É interessante notar como o hábito influencia para explicar o modo de agir do legislador, o mesmo ocorrerá para explicar o modo de agir do agente moral.

${ }^{332}$ Mill, (1843), 1999, A Lógica nas Ciências Morais, p. 89.
} 
a seus interesses imediatos. É argumento de Mill que não apenas os interesses pessoais dos indivíduos e legisladores são motivos de ação dos legisladores (quando se pensa a ciência política), mas a tradição e o hábito também determinam as ações, tanto dos legisladores quanto dos indivíduos em geral, por isso o método geométrico ou abstrato não pode ser utilizado para se fazer ciência social, pois este método é abstrato demais, não levando em conta causas contrárias ou outras causas para que se entenda o complexo fenômeno social.

Desta forma, assume-se, para Mill, que o interesse privado é uma força em constante ação, mas não explica tudo (ou seja, é tese deste trabalho com forte evidência dos escritos de Mill que a mais importante parte da influência das ações dos indivíduos e legisladores está em seu interesse pessoal, embora não seja o único componente responsável pela explicação das ações) ${ }^{333}$. O termo interesse próprio não inclui os fatos particulares, as circunstâncias que podem transformar um governo em bom ou ruim (ainda pensando sobre a hipótese de construir uma teoria política). Portanto, Mill reforça a importância do elemento circunstância que não possui espaço no modelo geométrico de se fazer filosofia, ao contrário, conforme se verá, o termo circunstância possui total importância no modelo de Mill, estando presente inclusive na natureza humana de seu indivíduo como uma característica, a saber: a capacidade de transformar-se ao longo do tempo.

Quanto à possibilidade de se construir uma Ciência Moral, contudo, no início deste capítulo descreveu-se que ela advém inicialmente da possibilidade de construir-se uma determinada natureza humana. Defende-se, nesta tese, que tal natureza é composta de leis da mente, da tese hedonista, ou seja, que o indivíduo busca prazer e foge da dor, e os outros elementos da natureza humana derivam seu valor desta tese (como o agir por hábito que leva em conta decisões passadas, mas que estão de acordo com a busca da felicidade e a fuga da dor, faculdades mais elevadas que dão origem à possibilidade da busca por um tipo de prazer mais elevado (como o prazeres humanos de ouvir uma música ou de ler um livro relativamente à faculdades menos elevadas que levam à busca prazeres menos elevados como prazeres que saciam o corpo) e a capacidade dinâmica que o indivíduo possui de transformar-se ao longo do tempo, de

${ }^{333}$ Mill, (1843), 892. (edição liberty fund). 
modificar seu caráter. O princípio de utilidade, conforme mencionado no início deste capítulo é base para a construção de princípios secundários ou regras morais (de uma moralidade propriamente dita), sendo que este princípio é uma regra que versa sobre ações, sobre como as ações deveriam ser e estas ações deveriam ser de uma determinada forma, o princípio da utilidade será uma norma que ditará a forma como as ações devem ser de acordo com a natureza humana determinada. Ele é um preceito moral (que é correto buscar prazer e errôneo buscar a dor) que é embasado na tese científica hedonista. Ele é derivado da prova lógica da tese hedonista da seguinte maneira: inicialmente observa-se que as pessoas buscam a felicidade e fogem da infelicidade e esta é uma ampla observação que atravessa os tempos e as nações. Esta lei pode ser formulada como uma lei empírica, porque está dentro dos limites da observação, embora seja uma ampla observação empírica, então por indução ela é aplicada às leis da natureza humana ou às leis da mente como à lei de associação (toda vez que os indivíduos realizam uma ação A esta ação vem associada a um prazer $\mathrm{V}$, a idéia da ação $\mathrm{A}$ passa, então, a ser associada a idéia do prazer $\mathrm{V}$ e é agradável, portanto realizar a ação A porque a ela está associada a idéia de um prazer $\mathrm{V}$, toda vez que o indivíduo realiza uma ação $\mathrm{B}$ esta ação vem associada a uma dor Y, sendo que a idéia da ação B vem associada à idéia de uma dor Y, e, portanto, é desagradável realizar a ação B e o agente moral pára de realizar a ação B), após a aplicação da associação, deduções são realizadas e comparadas novamente com a experiência e assim prova-se que os indivíduos fogem da dor e buscam o prazer. A tese hedonista é provada e ela é convertida no primeiro princípio da moralidade (arte) utilitarista, a saber: o princípio da utilidade. Note-se que o princípio da utilidade é construído a partir da natureza humana (das leis da mente e prazer e dor que são atributos da natureza humana) a partir do fato de que é agradável obter prazer e desagradável obter dor, portanto, o princípio da utilidade de Mill recomenda que se busque o prazer e fuja-se da dor, assim como o de Bentham, a diferença para o princípio de Bentham reside no fato de que muito mais coisas precisam ser ditas para que se entenda a idéia de prazer e dor ${ }^{334}$ e isto advém do fato de que a natureza humana do indivíduo teórico de Mill é mais complexa em relação ao indivíduo teórico de Bentham (pois além das leis da mente e da

\footnotetext{
${ }^{334}$ Mill, 1861,p. 55 "To give a clear view of the moral standard set up by the theory, much more requires to be said; in particular, what things it includes in the ideas of pain and pleasure”;(...)
} 
tese hedonista esta natureza é composta pelo agir por hábito, pelas faculdades mais elevadas que dão origem a tipos de prazeres de qualidades mais elevadas e a capacidade que o indivíduo tem de transformar-se ao longo do tempo. Este princípio de utilidade que abre espaço para muitas outras coisas sejam ditas para explicar o que está incluso na idéia de prazer e dor inclui, principalmente, os princípios secundários ou regras morais (como que não se mate, não se roube, que se desenvolva a coragem, que se desenvolva simpatia pelos outros, que se cumpram as promessas, que se desenvolva o gosto pelas artes) tendem a criar uma sociedade onde os homens possam confiar uns nos outros e aprimorar seus laços uns com os outros, sem realizar cálculos a todo instante, que possam desenvolver seu caráter de forma a gerar um máximo de bem-estar social.

Ainda no que diz respeito à possibilidade de construção de uma Ciência Política e referindo-se à segunda proposição política de Bentham denominada interesse dos homens do governo de se manterem no governo como sendo a única causa capaz de produzir nos legisladores um senso de identificação do interesse próprio com a comunidade, Mill alega ser esta proposição ainda menos admissível como uma verdade universal, pois muitos governos possuem forte identificação com aquilo que o povo pensa, ou seja o representa.

Com essas críticas que Mill efetua à escola de pensadores que adotam o método geométrico de proceder em ciências sociais como Bentham, Mill diz tentar mostrar o enorme número de circunstâncias e causas que ficaram de fora de seu sistema, bem como o elevado grau de abstração desta escola que acaba por prejudicar a explicação do complexo fenômeno social e por fim demonstra que este método não é científico o suficiente para incorporar o erro que pode afetar as suas conclusões.

"Não se deve supor e nem é, de fato, verdade, que esses filósofos tenham considerado que nas poucas premissas de sua teoria estivesse incluído tudo o que é exigido para explicar os fenômenos sociais ou para determinar a escolha das formas de governo e das medidas legislativas $e$ administrativas". [Mill, 1999, p. 91].

É, contudo, justo notar que o erro daqueles que utilizaram o método geométrico da maneira como Bentham o utilizou não foi tanto de substância (com relação 
ao conteúdo das premissas) quanto foi de forma, pois embora se suponha que as ações dos legisladores não sejam, de forma alguma, totalmente determinadas pelos seus interesses egoístas, é, principalmente, como uma segurança contra estes interesses egoístas que supervisões constitucionais são requeridas. É verdade, do mesmo modo, que as responsabilidades (obrigações legais) para com o governado constituem o único meio, praticamente disponível para criar um sentimento de interesse de identidade, nos casos, e nos pontos, onde aqueles sentimentos não existem suficientemente.

O grande problema de forma destas teorias está no fato de que consideraram as poucas premissas de suas teorias como incluindo tudo que é requerido para explicar o fenômeno social ou para determinar as formas de governo e medidas de legislação e $\operatorname{administração~}^{335}$.

Eles aplicaram seus princípios com inúmeras compensações. Contudo, de acordo com Mill, não são compensações que são requeridas, pois é anti-filosófico construir uma ciência que explique pouco do fenômeno e deixar o restante à prática da conjectura. Ao fazer ciência é necessário que o cientista comprometa-se, ao máximo, a incluir todas as causas no escopo da ciência, pois tem-se a tendência a dar uma atenção desproporcional às causas que a teoria leva em conta, enquanto subestima-se o resto, e, provavelmente deprecia-se a importância deste resto que pode ser muito importante para explicar as causas.

As deduções das quais as conclusões práticas são derivadas e aplicadas deveriam ocorrer a partir do todo, senão do todo, do máximo que uma teoria pode captar do complexo fenômeno social e não apenas a partir de uma ínfima parte das leis de natureza que dizem respeito, como ocorre na teoria de Bentham. O fenômeno da sociedade não depende de uma causa ou lei da natureza humana, sem consideração de modificações de outras causas. O todo das qualidades da natureza humana influencia aqueles fenômenos.

A teoria de Bentham é um importante exemplo do que Mill denomina de método geométrico de filosofar em ciência social. Tendo, então, analisado os dois métodos errôneos (o experimental ou químico e o geométrico seja por partir de preceitos para embasar a ciência, seja por partir de poucas causas para explicar um complexo

${ }^{335}$ Mill, 1843, p. 893. 
fenômeno social) parte-se para analisar o método adequado às ciências sociais que procede dedutivamente, pela dedução de várias e não apenas de algumas premissas, considerando cada efeito como um resultado agregado de muitas causas, operando por meio das leis da natureza humana ${ }^{336}$ (leis da mente, tese hedonista, agir por hábito, faculdades mais elevadas relativamente às faculdades menos elevadas e a capacidade de transformar-se ao longo do tempo). Ou seja, resta claro que o problema deste método dedutivo refere-se a deduzir conseqüências práticas de poucas premissas que não abarcam a totalidade das causas do fenômeno.

\subsection{Método físico ou concreto dedutivo que Mill chama de método adequado dedutivo às Ciências Sociais.}

1. O método direto e o método inverso dedutivo

Abaixo será mostrado o método a ser utilizado nas ciências sociais, inclusive na ciência que embasa a moral (uma arte de prescrever preceitos). $\mathrm{O}$ efeito produzido, no fenômeno social, por qualquer complexo conjunto de circunstâncias, resulta, precisamente da soma dos efeitos das circunstâncias tomadas separadamente quando aplicada às leis da natureza humana. A complexidade não surge do número de leis, mas do extraordinário número de circunstâncias que submetidos às leis, deduzidos e comparados à experiência cooperam rumo ao efeito.

Em outras palavras, Mill ressalta que as leis da natureza humana agindo conjuntamente com uma enorme variedade de dados ou elementos cooperam rumo ao efeito. A Ciência Social, entretanto, é uma ciência dedutiva, não do modelo da geometria, mas como daquelas mais complexas ciências físicas. Ou seja, Mill define um outro tipo de dedução que não é a chamada dedução geométrica, mas sim uma dedução que alia leis da natureza aos complexos elementos circunstanciais.

A dedução como é utilizada no modelo da física, por composição de causas, infere todas as causas de um dado efeito e as compõem quando submetidas a determinadas circunstâncias e deduzidas para serem novamente verificadas pela

${ }^{336}$ Mill, 1999, p.92. 
experiência. Seu método, em resumo, é o método concreto dedutivo utilizado em outras ciências físicas.

"Portanto a Ciência Social é uma ciência dedutiva; não, é verdade, segundo o modelo da Geometria, mas segundo o modelo das ciências físicas mais complexas. Ela infere a lei de cada efeito das leis de causação de que esse efeito depende; entretanto, não infere a partir da lei de uma causa apenas, como no método geométrico, mas considerando todas as causas que influenciam conjuntamente o efeito e compondo suas leis umas com as outras". [Mill, 1999, p. 93]

Os sentimentos e ações humanos são sem dúvida causados por leis da natureza humana (leis psicológicas e etológicas), conforme se vem demonstrando, quando se conhece todas as causas que geram um fenômeno não há dificuldade alguma em determinar a natureza deste fenômeno. Contudo, quando o número de causas é tal (as leis submetidas a muitas circunstâncias) é necessário compor a influência de todas as causas que geram determinado fenômeno complexo social, atingindo-se um objetivo que ultrapassa as possibilidades humanas.

Sabe-se que os cientistas que pesquisam a física não possuem recursos suficientes para calcular precisamente a ação mútua de três corpos gravitando um em relação ao outro no espaço, portanto, a dificuldade em calcular o resultado de tendências conflitantes que assumem inúmeras direções conflitantes e que se modificam, inerentes ao complexo fenômeno social, é ainda maior. Contudo, os pesquisadores, partindo da natureza humana, devem ser capazes de distinguir com eficiência as tendências que dependem das causas que influenciam o fenômeno e deveriam conseguir determinar a direção que cada uma das tendências, agindo sozinhas, imprimiriam à sociedade, bem como deveriam conseguir discriminar quais tendências são mais poderosas que outras.

A terceira parte do método dedutivo (a primeira sendo a descoberta das leis mais gerais da natureza por indução, a segunda parte a extração de consequiências pela aplicação de circunstâncias às leis mais gerais da natureza humana ou às leis etológicas) constitui a verificação que é, precisamente a comparação das conclusões do raciocínio com as leis empíricas, quando podem ser obtidas. A verificação, a posteriori, constitui o fundamento da confiança da ciência dedutiva. 
Há outro tipo de dedução que é denominado dedução inversa. A inversão da dedução implica em ao invés de deduzir as conclusões da natureza humana pelo raciocínio e verificá-las pela observação, em alguns casos, começa-se a obtê-las (as conclusões) da experiência (obter as leis empíricas) e depois estas são conectadas com os princípios da natureza humana que constituem, também, uma verificação. Em outros termos, Mill ressalta que às vezes realiza-se a dedução inversa que consiste em obter primeiro as leis da experiência e após compará-las com as leis da natureza humana (e isto também consiste em uma verificação).

“O resultado é apenas uma perturbação na ordem de precedência dos dois procedimentos que equivale, algumas vezes, à sua efetiva inversão: em vez de deduzirmos nossas conclusões pelo raciocínio e verificá-las pela observação, começamos, em alguns casos, por obtê-las provisoriamente pela experiência específica e posteriormente as conectamos com os princípios da natureza humana por meio de raciocínios a priori, raciocínios que constituem, assim uma real Verificação." [Mill, 1999, p. 95]

$\mathrm{O}$ autor argumenta que Comte considera esta ordem inversa de dedução como inseparavelmente inerente à natureza da especulação em ciências sociais. Ele observa a ciência social como essencialmente consistindo de generalizações da história, verificadas pelas leis da natureza humana. Para Mill há considerável espaço na pesquisa sociológica para o direto, bem como para o inverso método dedutivo. Ou seja, Mill está descrevendo que tanto o método inverso quanto o método dedutivo direto podem ser utilizados na pesquisa sociológica ${ }^{337}$.

Será mostrado, a seguir, que há um tipo de pesquisa sociológica ao qual o método da dedução direta é, em conjunto, inaplicável (no caso da pesquisa histórica), mas é neste caso mesmo que se podem obter as melhores leis empíricas. A estas pesquisas o método dedutivo é exclusivamente adaptado, ao inverso. Entretanto, há também, outros casos nos quais é impossível obter da observação direta as leis empíricas, mas estes são os casos nos quais o método dedutivo direto é menos afetado por objeções.

${ }^{337}$ Mill, (1843) p.897 (edição liberty fund). 
Deve-se começar, contudo, pela observação da ciência social como uma ciência da dedução direta e considerar o que pode ser concluído por esse modo de pesquisar, caso encontre-se dificuldades, parte-se para o método dedutivo inverso

\section{Dificuldades do Método Dedutivo Direto em Ciência Social}

Conforme mencionado anteriormente, neste capítulo, devido ao complexo fenômeno social de que trata as ciências sociais e sendo ela um sistema de deduções e composições de inúmeras causas, não podem ser uma ciência de predições positivas, mas apenas de tendências. Pode-se concluir das leis da natureza humana, aplicadas às circunstâncias $^{338}$ de um dado estado da sociedade que uma causa particular operará de uma certa maneira, a menos que algo contrário aja sobre ela, mas nunca se pode estar seguro em qual importância esta causa operará ou afirmar com certeza que esta causa não será contrariada, porque se pode raramente saber, mesmo que aproximadamente, todas as causas que podem coexistir com a dada causa e ainda menos pode-se calcular o resultado coletivo de tantos elementos.

Entretanto, um conhecimento que versa apenas sobre tendências é bastante valioso para predição. O objetivo em política prática é aplicar em qualquer dada sociedade o maior número possível de circunstâncias das quais as tendências são benéficas e remover ou fazer um esforço contrário, tanto quanto seja praticável, com relação às tendências ruins à sociedade. Um conhecimento das tendências dará uma considerável extensão deste poder de envolver a sociedade com o maior número de circunstâncias benéficas, embora sem o poder de prever acuradamente o resultado conjunto das causas.

A produção de um fenômeno social é dada por uma mistura de leis. Deve-se tentar entender uma sociedade, levando em conta o máximo da compreensão de suas tendências e circunstâncias. Mill afirma que não há fenômeno social que não seja influenciado por outras partes da condição da mesma sociedade. É possível interpretar

\footnotetext{
${ }^{338}$ As leis da natureza humana são sempre aplicadas às circunstâncias e é aí que as forças contrárias que compõem o fenômeno social são captadas, diferentemente do método geométrico utilizado pela escola de Bentham.
} 
que Mill $^{339}$ realiza uma analogia entre o corpo político e o corpo orgânico, pois há uma relação de dependência entre os órgãos, assim como há uma relação de dependência entre as causas do fenômeno social. Segue deste consenso que duas sociedades não podem ser semelhantes em seus fenômenos sociais, uma vez que muito provavelmente não serão semelhantes quanto às suas circunstâncias. E é por isso, que as leis causais, tendências devem ser ajustadas às circunstâncias de cada sociedade.

Cada causa, conforme suas causas se propagam pela sociedade, vem em contato com diferentes conjuntos de causas e circunstâncias e, portanto, os efeitos dos fenômenos são modificados. As causas poderão não ter a mesma tendência em um povo ou em uma época, é necessário que se faça uma nova análise das circunstâncias (para outro povo e outra época) e que sejam aplicadas às leis de natureza humana para serem depois deduzidas e verificadas no caso do método dedutivo direto, ou que se extraiam leis empíricas e que se verifiquem com as leis de natureza (no caso do método dedutivo inverso).

A ciência dedutiva não ensina um teorema, tratando de uma maneira universal sobre o efeito de uma causa, ao invés, ensina, como de fato vem-se mostrando, de que maneira é possível encontrar o teorema a partir das circunstâncias de cada dado caso. Não é dado o fenômeno da todas as sociedades, mas os meios de determinar o fenômeno de cada dada sociedade a partir dos elementos particulares ou dados da sociedade combinados às leis da natureza humana.

O modelo de indivíduo traçado neste trabalho parece manter-se importando quais as circunstâncias apenas nos casos das faculdades mais elevadas e no caso da capacidade que o indivíduo tem de transformar seu caráter, no caso da tese hedonista, das leis da mente e do agir por hábito, as circunstâncias parecem não variar estas características da natureza humana. Independente das circunstâncias, os homens buscam a felicidade como o único fim desejável de suas vidas (tese hedonista), ainda que inúmeras circunstâncias concorram para que isso não ocorra, a tese hedonista não deixa de ser verdadeira, os homens possuem certas leis da mente que não variam devido a circunstâncias, os homens têm a tendência a agir por hábito de uma forma bastante independente das circunstâncias também, contudo, a capacidade que os homens têm de

${ }^{339}$ Mill, (1843), 1999, p.899. 
se transformar ao longo do tempo é totalmente dependente das circunstâncias (sendo que uma parte disso dependente de sua vontade) e outra parte ainda mais importante dessa transformação depende, sem dúvida, das circunstâncias geradas (favoráveis ou não) pelos arranjos institucionais vigentes. As faculdades mais elevadas, uma característica importante da natureza humana porque dão origem a prazeres de qualidade mais elevada, dependem de circunstâncias favoráveis para serem ativadas, em outros termos, é necessário um arranjo institucional que proporcione educação adequada aos indivíduos de modo que estes indivíduos assumam gosto pela apreciação das artes, da leitura, da música, pela virtude (por desejar fazer o bem aos outros, por ser simpático a isto), etc.

"Percebe-se que a comparação da vida epicurista à vida dos animais é degradante precisamente porque os prazeres dos animais não satisfazem as concepções humanas de felicidade. Os seres humanos possuem faculdades mais elevadas do que os apetites animais, e uma vez que tomam consciência delas não consideram como felicidade algo que não as satisfaça.” [Mill, 1861, p.188].

Conforme mencionado anteriormente, as proposições que podem ser organizadas pela ciência dedutiva são, entretanto, no estrito senso da palavra hipotéticas $^{340}$. As proposições são combinadas a conjuntos de circunstâncias e apontam como uma causa determinada agiria naquelas circunstâncias, tendo como pressuposto que nenhuma causa contrária agiria. Para que as conclusões sejam consideradas verdadeiras é necessário que o conjunto de circunstâncias seja retirado de uma determinada sociedade existente. $\mathrm{O}$ modo de se obter uma aproximação à verdade concreta é tomar um grande número de circunstâncias e comparar à natureza humana e então por dedução extrair tendência, conseqüências que podem ser verificadas, novamente, a posteriori (no caso da verificação direta).

O modo hipotético que considera poucas causas ou uma causa como um modo de obter proposições gerais deve, entretanto, ser limitado às classes dos fatos sociais que estão sob a influência de poucas circunstâncias, como a economia política, por exemplo.

\footnotetext{
${ }^{340}$ Isto está de acordo com o texto intitulado On the Definition of Political Economy, 1824.
} 


\section{A Economia Política como ciência social pode ser estudada a parte.}

É possível depreender que Mill argumenta que é verdade que tudo que toma parte nas operações da sociedade não deixa de influenciar as outras partes da sociedade, mas é verdade também que diferentes fatos sociais são dependentes, em primeiro lugar e de uma maneira imediata, de diferentes tipos de causas. Assim fenômenos sociais podem e devem ser estudados separadamente assim como se faz com o estudo do corpo (da fisiologia e da patologia de cada um dos principais órgãos e tecidos, embora cada um aja sobre o outro).

Destas considerações depreende-se a existência de distintos e independentes ramos da especulação das ciências sociais, embora estes ramos de estudo não sejam independentes. Há, por exemplo, uma ampla classe do fenômeno social no qual as causas imediatamente determinantes são, principalmente, aquelas que agem por meio do desejo de auferir riqueza e nas quais a lei psicológica que diz respeito é principalmente aquela na qual um ganho maior é preferido a um menor ganho.

No que diz respeito a isto, é possível interpretar que Mill está pronunciandose sobre aquela parte do fenômeno da sociedade que emana das operações industriais ou produtivas da humanidade e daqueles atos nos quais a distribuição de produtos das operações industriais toma lugar, enquanto não sofre modificação.

Raciocinando a partir daquela lei da natureza humana e das principais circunstâncias externas que operam sobre a mente humana, é possível estar apto a explicar e predizer esta parte do fenômeno da sociedade, abstraindo as outras circunstâncias que influenciam tal fenômeno da sociedade. Um ramo da ciência denominado Economia Política pode ser construído a partir deste método dedutivo concreto.

O motivo que sugere a separação desta porção do fenômeno social do restante refere-se ao fato de que este fenômeno depende, principalmente, de apenas uma classe de circunstâncias. Isto também está expresso em seu texto On The Definition of Political Economy onde ele define o significado de Economia Política. 
Nesta definição, é possível interpretar que Mill ${ }^{341}$ conclui que em Economia Política assume-se que a humanidade está unicamente empenhada em obter a maior quantidade de riqueza com o mínimo de trabalho e o mínimo de negação ao lazer. As conclusões da economia política, por suprimir os outros motivos de ação da humanidade, falharão ao serem aplicadas à explanação ou predição dos eventos reais, a não ser que sejam modificadas pelo empréstimo correto ao grau de influências exercidas por outras causas. Portanto, é requerida ajuda do método da verificação para ajustar as predições em economia à complexidade do fenômeno real.

É possível concluir da análise do que Mill ressalta que as conclusões de premissas assumidas da teoria devem ser ajustadas conforme o contexto (seja o tempo em que vive o economista político, seja a nação em que ele vive). Mesmo que o economista político seja acusado de construir uma fábrica permanente (a teoria) sobre materiais transitórios (o fenômeno social), ou seja, de construir premissas sob um arranjo social mutável, arranjo este que possui uma natureza flutuante ou progressiva e seja acusado de anunciar proposições universais que não se aplicam a nenhum estado de sociedade a não ser aquele pensado, isto não invalida o valor de suas proposições consideradas com referência ao estado de sociedade pensado por ele, pois seu método de investigação é universalmente aplicável, embora, nem sempre, suas conclusões sejam localmente aplicáveis. O mesmo ocorre no ramo da moralidade, embora a moralidade seja uma arte e não uma ciência, pois ela dita preceitos como não mate, não roube, seja corajoso, aprecie a arte, etc, ela está ancorada em uma ciência e esta ciência é auferida, conforme já explanado, com os métodos das ciências físicas (indutivo, dedutivo, permitindo a composição de causas e a verificação) e não com o método químico ou geométrico como faz Bentham, pois para obter a tese hedonista (tese que embasa toda a moralidade utilitarista) primeiro extrai-se esta tese como uma lei empírica depois ela é combinada com as leis da mente como a lei de associação (uma ação A é associada a um prazer V, se um indivíduo realizar sucessivamente uma ação B que está associada a um prazer X, então sempre que realizo uma ação $\mathrm{A}$ ou $\mathrm{B}$ o prazer $\mathrm{V}$ e $\mathrm{X}$ retorna à mente do indivíduo $\mathrm{L}$ e tal indivíduo associa as idéias das ações A e B às idéias dos prazeres $\mathrm{V}$ e X com estados mentais agradáveis e por isso o indivíduo continuará a praticar as ações A e B, se

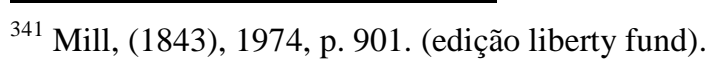


as ações associassem a dor o indivíduo L não mais efetuaria aquelas ações) e assim deduzindo essas combinações de circunstâncias com as leis da mente e verificando-as com as leis empíricas novamente, é possível provar a tese hedonista de que os indivíduos buscam prazer e fogem da dor, porque o prazer é agradável em si e a dor desagradável em si. Deste teorema da ciência converte-se o princípio primeiro ou o preceito primeiro da moralidade utilitarista, o princípio da utilidade que prescreve ser correto buscar o prazer e ser errôneo buscar a dor, sendo a busca da felicidade o único fim desejável, os outros fins constituem parte da busca pelo fim principal, sempre associados à busca da felicidade (pois como ressalta Mill em sua própria explicação do princípio da utilidade muito mais coisas precisam ser ditas para que se entenda o que é a idéia de prazer e dor e isto está de acordo com a sua concepção de ciência social para explicar o complexo fenômeno social, embora ele continue sendo um utilitarista e estes outros elementos devam subordinar-se à tese hedonista). Além disso, a natureza humana é composta do agir por hábito, de faculdades mais elevadas que dão origem a prazeres de qualidades mais elevadas e da capacidade de melhorar seu caráter ao longo do tempo, todas essas características estão associadas à geração de prazer, ou derivam seu valor dela. Todas estas novas características relativamente ao indivíduo teórico de Bentham, como o agir por hábito, as faculdades mais elevadas, a capacidade de melhorar o caráter ao longo do tempo, trazem a possibilidade do estabelecimento de uma moralidade positiva propriamente dita, da construção de um maior número de regras morais estabelecidas que não são questionadas a todo instante no momento da ação, uma vez que o indivíduo de Mil, agora, não precisa fazer cálculos a todo instante para agir. $\mathrm{O}$ agir por hábito traz benefícios, conhecer os princípios secundários (as regras morais que foram sim derivadas do princípio de utilidade, mas que são fruto de decisões passadas são possíveis de serem estabelecidas porque o indivíduo pode agir por hábito). Seria até mesmo uma hesitação moral não conhecer os princípios secundários de ação, no momento do ato, seria demonstrar uma fraqueza moral ao agir, aquele que precisasse recorrer ao princípio primeiro em todos os momentos de sua ação. Além disso, as faculdades mais elevadas que uma vez ativadas dão origem a prazeres mais elevados abrem espaço para um tipo de vida verdadeiramente humano, com apreciação de valores humanos (como a apreciação da arte, da educação e da moralidade) que nenhum outro tipo de animal é capaz de pensar ou sentir (lembrando 
que os pensamentos, sentimentos e volições são todos estados mentais), a possibilidade de modificar o caráter ao longo do tempo, também é uma característica que demonstra a possibilidade de que os indivíduos aprimorem seu caráter de modo a construírem os melhores preceitos morais dadas as circunstâncias e arranjos sociais em um dado tempo e local, mas isto não é parte de um cálculo feito a cada ação, visando apenas seu interesse próprio, mas antes uma característica de sua natureza aprimorar regras morais que possam beneficiar a todos, embora ele não tenha a obrigação de agir desta forma, nada impede que conforme refine seu caráter o faça assim.

Em economia política, uma ciência social, que serve de exemplo, para que se entenda o método físico direto, os economistas políticos controlaram o grau de precisão das leis (sob livre competição, determinam a renda, lucros, e salários recebidos pelos rentistas, capitalistas e trabalhadores, em um estado de sociedade no qual as classes são tomadas como completamente separadas), por isso não terão dificuldades em determinar as diferentes leis que regulam a distribuição do produto entre as classes interessadas, em qualquer dos estados de cultivo e a propriedade da terra. Em outras palavras, o que os economistas políticos devem fazer é ajustar as conclusões de suas premissas aos dados da realidade. Portanto, à Economia pode ser aplicado o método dedutivo concreto ou físico.

\section{Etologia Política, ou a ciência do caráter nacional}

Há outro ramo das ciências sociais que também pode ser estudado a parte e este ramo é denominado etologia política. Isto ocorre porque apenas uma classe de fatos sociais (a etologia política ou as causas que formam o caráter nacional) exerce influência sobre todo o resto dos fenômenos sociais. As causas que determinam o caráter nacional ou a etologia política seriam, de todos os ramos, o menos desenvolvido até então. A etologia política por ser as causas que modificariam o caráter nacional. Estas ditariam como as instituições ou arranjos institucionais deveriam ser, para que se auferisse um determinado tipo de caráter nacional desejado.

Para Mill as leis do caráter social são as mais importantes classes de leis sociológicas porque determinam instituições e arranjos sociais que muito provavelmente 
criarão certas circunstâncias sociais capazes de moldar o caráter de um povo. Assim, os sentimentos, hábitos, opiniões e ações de um povo, apesar de ser, em grande medida conseqüência de ações que o precedem e é interessante que seja assim, uma vez que os homens não se lançam ao mundo sem princípios secundários, regras morais pensadas morais pensadas de antemão, é verdade também que sentimentos, hábitos, opiniões, leis, costumes e ações podem modificar de acordo com leis causais de sociedades que seguem as sociedades passadas (em períodos críticos, dada a característica dinâmica dos indivíduos e um balanço entre prazer e dor, a diferença de Mill para Bentham é que isto é feito de geração para geração, como uma reflexão e não a cada ação como um indivíduo robótico de Bentham.

"De todos os ramos subordinados da ciência social este é o que está mais completamente em sua infância. As causas do caráter nacional são raramente compreendidas e o efeito das instituições ou arranjos sociais sobre o caráter do povo é, em geral, aquela parte de seus efeitos que é menos notada e menos compreendida. (...) Enfim $e$ sobretudo, o caráter, isto é, as opiniões, sentimentos $e$ hábitos do povo, apesar de ser, em grande parte, resultado do estado da sociedade que o precede é também, em grande parte, causa do estado de sociedade que o segue;",[Milll, 1999, p. 104].

A tese de Mill é que quanto mais refinada estiver a ciência da etologia e quanto menor forem as diversidades entre caráter nacional e individual, menor se tornará, provavelmente, o número de proposições que serão consideradas seguras erigir e princípios universais de natureza humana.

As causas que influenciam o estado etológico de um povo não podem ser tratadas independentemente da etologia política. Por este motivo, não pode haver uma ciência de governo separada, pois este é o caso em que as causas e os efeitos estão misturados com qualidades de uma época ou de um povo determinado.

Deve-se, desta forma, entender a Ciência Geral da sociedade enquanto distinta dos ramos separados das ciências (cada um dos quais com suas conclusões sujeitas ao controle soberano das leis da ciência geral). Como será mostrado nada que se 
assemelhe a um caráter científico relativo a estas leis da ciência geral é possível senão pelo método dedutivo inverso.

5. As leis empíricas da ciência social

Nas ciências dedutivas em geral, como por exemplo, na própria etologia, é necessário um trabalho anterior com os fatos observados para a comparação com as conclusões da teoria. Esse trabalho anterior consiste em encontrar proposições gerais que manifestem o que é comum aos fatos observados; estas proposições são as chamadas leis empíricas dos fenômenos. A pergunta que cabe fazer, então, é se há leis empíricas na história. A resposta é sim, é possível obter leis empíricas, muitas vezes inferindo efeitos a partir das causas.

No caso em que as causas dos fatos sociais não podem ser observadas diretamente, a lei empírica dos efeitos fornece material para a lei empírica das causas (o que neste caso é tudo o que se pode obter $)^{342}$. Entretanto, as causas imediatas dependem de causas remotas e a lei empírica obtida por esse modo de observar só pode ser admitida se houver razão para pensar que não ocorreram mudanças nas causas remotas das quais dependem as causas imediatas.

Mesmo que seja possível auferir leis empíricas é necessário que o processo todo de extração de consequiências das leis causais e verificação seja dedutivo. Em outras palavras, este mesmo processo dedutivo deve ser aplicado para generalizações baseadas na história. As generalizações da história não somente existem como devem ser confirmadas conectando-as com as leis psicológicas e etológicas das quais realmente dependem (através do método dedutivo inverso).

6. A maneira de verificar certa causa social em meio a um grande número de causas agindo simultaneamente

Para alguns fenômenos sociais torna-se impossível obter leis empíricas prévias para comparar com as conclusões das teorias. Estes são os casos em que se deseja

${ }^{342}$ Mill, (1843), 1999, p, 106. 
determinar o efeito de uma certa causa social em meio a um grande número de causas que agem simultaneamente.

Contudo, apesar da verificação direta ser impossível, há uma verificação indireta que sempre é possível. A experiência não pode verificar uma dada proposição da teoria, mas pode verificar a suficiência geral da teoria, uma vez que esta esteja pronta. Antes de confiar na aplicação da teoria sobre a influência de uma causa particular, dadas determinadas circunstâncias, deve-se ser capaz de explicar todas as partes dos fenômenos sociais que esta determinada causa tem a tendência de influenciar, caso não seja possível, isto significa que os fatos que deveriam ser incluídos na teoria ainda não o foram.

A prova de que uma determinada ciência dá conta de prever o futuro é a demonstração de que consegue prever o passado e o presente. Caso haja algum elemento que não consiga prever no passado ou no presente isto constituirá um fenômeno residual. Tal fenômeno residual exigirá explicação ou através da busca de circunstâncias que estejam de acordo com os princípios da teoria ou através do aperfeiçoamento da própria teoria.

3.8 A seguir descreve-se o método dedutivo inverso ou o método histórico. Ou aquele que considera primeiro a experiência para depois comparar com as leis da natureza humana.

1. Distinção entre a ciência geral da sociedade e especiais pesquisas sociológicas

Existem dois tipos de pesquisa sociológica, a saber: a) no primeiro caso a questão proposta é qual efeito se seguirá de uma dada causa, com uma certa condição geral das circunstâncias sociais sendo pressupostas. Como, por exemplo, qual seria o efeito de impor ou repelir as leis do milho, de abolir a monarquia ou introduzir o sufrágio universal, na presente condição da sociedade e da civilização em qualquer país europeu ou sob qualquer outra dada suposição com respeito às circunstâncias da sociedade em geral, sem referência às mudanças que devem tomar lugar ou que devem estar em progresso naquelas circunstâncias e b) no segundo caso, no segundo tipo de pesquisa quer-se saber quais são as leis que determinam aquelas circunstâncias gerais. Nesta 
última pesquisa a questão é: não qual será o efeito de uma dada causa em um certo estado da sociedade, mas quais são as causas que produzem os fenômenos que compõem estados da sociedade em geral. Em outras palavras, interpreta-se que no primeiro tipo de pesquisa toma-se um dado estado da sociedade e no outro tipo de pesquisa quer-se saber quais são as causas que geram determinados estados de sociedade.

\section{O que é significado por um Estado de Sociedade?}

De acordo com este autor, o que é denominado por um estado de sociedade é o simultâneo estado de todos os importantes fatos ou fenômenos sociais. Estes são os graus de conhecimento, cultura moral e intelectual existentes em uma sociedade, o estado da indústria, da riqueza e de sua distribuição, as ocupações habituais da comunidade, sua divisão em classes e a relação das classes entre elas, as crenças comuns, seus gostos, sua forma de governo, o caráter etc ${ }^{343}$. Enfim, tudo que é dado em um determinado tempo. Esta pode ser a denominada estática social ou o equilíbrio social. Esta observação abre a importante questão do progresso do homem em sociedade que se refere ao segundo tipo de pesquisa sociológica enunciada, a saber; quais são as causas que levaram a este tipo de Estado de Sociedade.

\section{O progresso do homem e da sociedade.}

Algo importante a ser destacado que, inclusive, constitui uma das características importantes das ciências de natureza humana e da sociedade refere-se ao fato de tratar de um assunto cujas propriedades são mutáveis. Não que estas propriedades sejam mutáveis de um dia para o outro, mas de tempos para tempos, em que não apenas as qualidades dos indivíduos variam (conforme é tese deste trabalho o modelo de indivíduo teórico de Mill é dinâmico, possui uma capacidade intrínseca de transformar-se ao longo do tempo), mas também as qualidades da sociedade sofrem alterações de um tempo para o outro.

${ }^{343}$ Mil, 1999, p.112. 
A palavra progresso não deve ser entendida como melhoramento ou tendência ao melhoramento. É concebível que as leis da natureza humana podem determinar e mesmo necessitam determinar uma certa série de mudanças no homem e na sociedade que não significam melhoramentos. Entretanto, constitui pensamento de Mill que as mudanças têm uma tendência a um estado mais feliz, caso os arranjos sociais produzam circunstâncias favoráveis a formar o caráter dos indivíduos.

"Os termos Progresso e Progressividade não devem ser entendidos, aqui, como sinônimos de aperfeiçoamento ou tendência ao aperfeiçoamento. É concebível que as leis da natureza humana possam determinar e até mesmo necessitar uma certa série de mudanças não sejam, em todos os casos ou em sua totalidade, aperfeiçoamentos. De fato, é minha crença que a tendência geral é e continuará a ser, salvo exceções ocasionais e temporárias, uma tendência ao aperfeiçoamento, a um estado melhor e mais feliz". [Mill, 1999, p. 114]

Esta, entretanto, não é uma questão do método da ciência social, mas um teorema da ciência. À questão metodológica apenas interessa que ocorrem mudanças no fenômeno da sociedade de um período para outro. Este período é marcado por um intervalo de ao menos uma geração (este é o período que marcam mais distintamente mudanças sucessivas), durante o qual um novo conjunto de seres humanos foram educados (pela mudança no caráter da humanidade derivada de mudanças nas circunstâncias) e tomaram posse da sociedade.

O progresso ou mudança da humanidade firmou-se como a fundação do método de filosofar em ciência social (uma vez que a mudança das circunstâncias são levadas em conta para a formulação das leis causais seguindo o método dedutivo físico), e prevaleceu sobre os modos geométricos, experimentais e químicos. Tal método consiste em tentar descobrir a lei do progresso, pelo estudo e análise dos fatos gerais da história (quando se pensa em construir uma ciência do governo, uma ciência geral, uma etologia política). Uma vez determinada a lei do progresso ela deve permitir prever eventos futuros. $\mathrm{O}$ autor ressalta que esta sucessão que se pode traçar entre diferentes estados da 
sociedade e da civilização que a história apresenta só pode ser por meio de leis empíricas $^{344}$.

A sucessão de estados da mente humana e da sociedade humana não têm uma lei independente, ela depende de leis psicológicas e leis etolológicas que governam a ação de circunstâncias sobre o homem e do homem sobre as circunstâncias. É concebível que aquelas leis da mente humana devem ser tais e as circunstâncias devem ser tais para determinar as sucessivas transformações do homem e da sociedade a uma dada e invariável ordem ${ }^{345}$. Tal afirmação demonstra como Mill pensa a sociedade a partir do indivíduo.

"A sucessão de estados da mente e da sociedade humanas não pode ter uma lei própria independente, mas deve, necessariamente, depender das leis psicológicas e etológicas que governam a ação das circunstâncias sobre os homens $e$ dos homens sobre as circunstâncias".[Mill, (1843), 1999, p. 114].

Não pode ser o objetivo último da ciência descobrir uma lei empírica. No entanto, esta lei empírica, histórica poderia ser conectada com as leis psicológicas e etológicas, conciliando assim a dedução com a evidência histórica. Desta conciliação a lei empírica pode ser convertida em lei científica. De acordo com Mill, Comte mostrou a necessidade de conciliar todas as generalizações da história com as leis da natureza humana. Portanto, é possível perceber que o método dedutivo inverso leva em conta as leis da história, mas pretende conciliá-las com as leis da natureza humana que são as leis da mente e as leis da etologia (como exemplo de lei etológica, tem-se: a experiência torna o homem cauteloso).

4. As leis da sucessão dos estados da sociedade só podem ser determinadas pelo método dedutivo inverso.

As generalizações da história devem ser introduzidas com fundamento na natureza humana, contudo, Mill não considera possível fixar a priori, a partir dos princípios da natureza humana e de circunstâncias gerais a ordem na qual o

${ }^{344}$ Mill, (1843), 1974, p. 914.

${ }^{345}$ Mill, (1843), 1999, p. 114-115. 
desenvolvimento humano deve tomar lugar. Depois dos primeiros termos da série, a influência exercida sobre cada geração pelas gerações precedentes torna-se mais e mais preponderante sobre as outras influências. Inclusive, o que os indivíduos são em um determinado período do tempo e o que ele faz é, em um pequeno grau resultado de circunstâncias universais do gênero humano, mas principalmente, o que o agente é e faz é resultado de qualidades produzidas nos indivíduos por toda história precedente da humanidade.

A história fornece as leis empíricas da sociedade. Sendo que o principal problema da sociologia geral é determinar estas leis e conectá-las com as leis da natureza humana, por deduções mostrando que estas leis naturais em combinação com as leis empíricas devem influenciar de uma determinada forma o comportamento humano. Este método é o método de dedutivo inverso.

A combinação da tese hedonista com as leis da mente consistiu em um bom exemplo disto (da aplicação do método dedutivo inverso, para descoberta de uma lei causal da natureza humana, a saber que os indivíduos agem buscando o prazer e fugindo da dor pelo valor intrínseco que possuem), pois a tese hedonista, pode ser descrita como uma lei empírica da sociedade (que os indivíduos buscam o prazer e fogem da dor) quando a sociedade é entendida como a composição de indivíduos.

\section{Estática Social}

As leis empíricas da sociedade são de dois tipos, a saber: a) algumas são uniformidades de coexistência, estáticas e b) algumas são de sucessão, são dinâmicas. Quando a ciência está ocupada em determinar e verificar as uniformidades de coexistência elas são chamadas estática social, quando a ciência está preocupada em determinar e verificar as leis de sucessão, as causas que geram mudanças sociais, elas são chamadas de dinâmica social. Estas leis são correlatas, em mecânica, com as condições de equilíbrio (seria a estática) e aquelas do movimento (seriam as leis de sucessão). As primeiras leis estabelecem as condições de estabilidade na união social, as segundas estabelecem as leis do progresso. A dinâmica social é a teoria da sociedade considerada 
em um estado de movimento progressivo, enquanto a estática social é a teoria do consenso, como existindo entre diferentes partes do organismo social.

Mesmo em estática sociológica deve-se considerar a existência de relações necessárias entre todos os aspectos possíveis do mesmo organismo social ${ }^{346}$. Não importa quais elementos sociais sejam escolhidos, deve-se facilmente reconhecer que este sempre possui uma conexão mais ou menos imediata com todos os outros elementos, mesmo que a primeira vista o elemento escolhido pareça ser independente dos outros.

Pode-se dizer que a consideração dinâmica do desenvolvimento progressivo da humanidade civilizada fornece um meio ainda mais eficaz de efetuar a verificação do consenso do fenômeno social, pela demonstração da maneira na qual a mudança do fenômeno social opera sobre outro. Entretanto, esta verificação dinâmica deve ser precedida por uma confirmação de um tipo estático.

Estas considerações são seguidas pelo estabelecimento de uma das mais importantes correlações que muitas vezes são negligenciadas, a saber: entre a forma de governo existente em uma sociedade e o estado de civilização.

Um dos principais resultados da ciência social estática seria estabelecer os requisitos da união política estável. Existem algumas circunstâncias que, sendo encontradas em todas as sociedades, sem exceção, e em mais importante grau onde a união social é mais completa, podem ser consideradas (quando as leis psicológicas e etológicas confirmam a indicação) como condições de existência do fenômeno complexo chamado um estado social que se deseja auferir. As circunstâncias que seriam encontradas como condições de existência do fenômeno complexo chamado estado social desejado seriam obtidas pela comparação de diferentes formas e estados da sociedade. Elas transformar-se-iam em regularidades; leis empíricas, seguindo as leis de natureza humana que poderiam conciliar os processos (dinâmicos e estáticos) e aumentar a evidência da prova. As generalizações poderiam ser elevadas a verdades científicas. A seguir apresentam-se as condições de estabilidade social, para que tal estado social seja auferido.

\footnotetext{
${ }^{346}$ Conforme mencionado, apenas para algumas ciências cujo conjunto de circunstâncias é, na média, pequeno, estuda-se em separado como a Economia Política. Contudo, quando se pensa um estado de sociedade, como no caso de uma estática social, deve-se pensar as relações entre todos os elementos sociais.
} 
A primeira condição de estabilidade social é um sistema de educação voltado a uma disciplina que treine os seres humanos no hábito, e no poder de subordinar seus impulsos pessoais ao que forem considerados os fins da sociedade, em outras palavras, os indivíduos poderiam ser educados a fazer convergir seus interesses pessoais aos interesses coletivos.

A segunda condição da estabilidade da sociedade política é mantida pelo sentimento de lealdade ${ }^{347}$ a algo que todos os indivíduos de uma sociedade concordam. Opiniões divergentes não afetariam o princípio fundamental do sistema de união social que é a condição habitual do corpo político.

A terceira condição essencial de estabilidade na sociedade política é um princípio de coesão entre os membros da mesma comunidade ou estado. Não se afirma aqui o sentido vulgar de nacionalidade que possuiria um sentido antipático aos estrangeiros. Interpreta-se o texto de Mill como afirmando um princípio simpático, não hostil, da união e não da separação. Seria afirmado um sentimento de interesse comum entre aqueles que vivem sob o mesmo governo e estão contidos dentro das mesmas fronteiras naturais e históricas. Aquela parte da comunidade que estabeleceu um valor de conexão sente que é um único povo, que sua sorte é que todos os indivíduos se mantenham juntos.

"Eu quero dizer com isso que uma parte da comunidade não se considera estrangeira em relação a outra parte, que elas valorizam sua conexão, sentem que constituem um povo, que seus destinos são solidários, que o mal a um de seus compatriotas é um mal a elas mesmas e que não desejam, rompendo a união, se livrar egoisticamente da parte que lhe cabe em qualquer dificuldade comum”. [Mill, (1843), 1999, p. 123].

\section{Dinâmica social}

A consideração da ordem sucessiva dos estados da sociedade é propriamente o estudo da dinâmica social, contrariamente às leis derivadas da estática social que são

\footnotetext{
${ }^{347}$ Alguém aqui poderia argumentar que isto interferiria nas liberdades individuais dos agentes, mas é claro que Mill defende este tipo de educação, considerada a condição de que tais liberdades sejam preservadas.
} 
determinadas pela análise e comparação dos diferentes estados de sociedade sem levar em consideração a sucessão dos diferentes estados de sociedade. O objetivo da dinâmica social é observar e explicar as seqüências das condições sociais. Esta parte do estudo da ciência social alcançaria toda perfeição de que é suscetível se cada uma das principais circunstâncias gerais de cada geração fosse remetida às suas causas na geração precedente, através de leis derivadas (estas leis são as leis do meio) na medida em que a sociedade avança e estados sociais geram-se uns aos outros.

Os princípios do meio não são as leis empíricas, estas últimas são mais facilmente estabelecidas a partir das generalizações históricas. Elas consistem em tendências gerais que podem ser percebidas em sociedade, mas estas leis continuam dependendo das leis elementares; mais diretamente das leis do meio (etológicas políticas). Poder-se-ia realizar algumas generalizações relacionadas à dinâmica social como: as qualidades mentais tendem a prevalecer sobre as qualidades físicas dos indivíduos, na medida em que a sociedade avança e muitas outras verdades parecidas a estas poderiam ser acrescentadas, pois satisfazem os investigadores comuns, mesmo os da escola histórica. No entanto, no que diz respeito a estes resultados, formular estas leis empíricas representa grande distância das leis elementares da natureza humana das quais dependem em etologia política, para que essas proposições possam passar a ser corolários diretos dos princípios elementares. Desta forma, tais proposições, como; conforme a sociedade avança as qualidades mentais tendem a prevalecer cada vez mais sobre os indivíduos, conservam o caráter de lei empírica, aplicável dentro dos limites da observação presente, sem que se tenham os meios para determinar seus limites reais e para julgar se as mudanças que estiveram em progresso estão destinadas a prosseguir, a acabar ou a ser revertida, porque não se possui suas leis causais.

As leis empíricas dos eventos históricos podem ser obtidas de uma melhor forma quando o cientista não ficar apenas no campo da observação de mudanças que se manifestam nos elementos separados da sociedade, que indicam apenas relação entre fragmentos do efeito e correspondentes fragmentos da causa. Para que se obtenham melhores leis empíricas torna-se necessário combinar uma visão estática do fenômeno social com uma visão dinâmica, levando em conta, as mudanças progressivas dos diferentes elementos, assim como a condição estática de cada um dos elementos e, então, 
obter, empiricamente, a lei de correspondência entre estados simultâneos, bem como entre mudanças simultâneas dos estados citados. Uma vez verificada a lei de correspondência dos estados, ela se tornaria a verdadeira lei científica do desenvolvimento da humanidade e esta lei seria fundamental para determinar uma característica da natureza humana do indivíduo que é a capacidade que ele tem de transformar-se ao longo do tempo.

Para Mill o progresso é o elemento central, é o principal agente do movimento social. A sucessão dos fatos é apresentada em um tipo de ordem espontânea e esta ordem é mais próxima da ordem real do que poderia ser obtida por qualquer processo empírico, sendo que ela é obtida por esta lei de correspondência entre estados simultâneos com mudanças progressivas.

Segundo o autor, a ordem do progresso humano, em todos os aspectos, dependerá, principalmente, da ordem do progresso nas convicções intelectuais, a busca da verdade a respeito de si mesmo e do mundo (faculdades especulativas) estão entre as propensões mais poderosas da natureza humana ou ocupam um lugar predominante na vida dos indivíduos, que depende da lei das sucessivas transformações das opiniões humanas, sendo que estas leis combinadas determinam uma importante característica humana denominada, neste trabalho, como capacidade que o indivíduo tem de transformar-se ao longo do tempo (conforme vem-se afirmando, o modelo de indivíduo do Mill é dinâmico, ele transforma-se com o tempo). Todas as outras disposições da natureza humana que contribuem para o progresso do homem dependem do princípio descrito acima como meio para realizar sua obra. Por exemplo, o estado do conhecimento em uma época dada é o limite dos aperfeiçoamentos industriais possíveis em uma determinada época e o progresso que a indústria deve seguir depende do progresso do conhecimento. Mill ressalta que é causa de um estado não civilizado ou semi-civilizado (pois tende a desunir os homens) o egoísmo como motivo das ações e tal motivo de ação seria disciplinado apenas quando um sistema comum de opiniões fosse conquistado e que os homens se submetessem a ele por acreditar em tal sistema de opiniões (isto seria conseguido através da força, somente em casos quando ofensas são geradas. A principal causa da convergência de opiniões seria os melhoramentos educacionais e arranjos institucionais), mas este indivíduo pode modificar-se, fazer convergir seus interesses com 
o da sociedade, porque ele tem em sua natureza essa capacidade intrínseca de transformar-se. Não obstante, tem-se argumentado que esta característica está submetida à tese hedonista, ou em outros termos, faz parte da finalidade humana que é a busca da felicidade, ainda que tal felicidade seja entendida como a busca da felicidade coletiva ou aumento de bem-estar coletivo. Desta forma, o estado das faculdades especulativas admitido pela inteligência determina, essencialmente, o estado político e moral da comunidade e até mesmo o material.

"Além disso, como as inclinações mais fortes da natureza humana não civilizada ou semi-civilizada (isto é, as puramente egoístas e aquelas de caráter simpático que compartilham, em sua maior parte, da natureza do egoísmo) tendem evidentemente, por si mesmas, a desunir os homens $e$ não a uni-los, a torna-los rivais e não aliados, a existência social só é possível quando se disciplina estas inclinações mais poderosas, subordinando-as a um sistema comum de opiniões.”[Mill, (1843), 1999, p. 126]

Estas conclusões deduzidas das leis da natureza humana estão em perfeito acordo com os fatos gerais da história, uma vez que toda mudança considerável historicamente conhecida, quando não efetuada por forças externas, ocorre por uma mudança de extensão proporcional no estado do conhecimento geral ou nas crenças predominantes (que mais uma vez é argumentado, neste trabalho, ser possível, porque o indivíduo possui uma característica intrínseca em sua natureza relacionada à capacidade de transformar-se ao longo do temo, ainda que tal característica esteja subordinada à busca pela felicidade consciente ou inconscientemente). A ordem do progresso dependerá, em todos os aspectos, da ordem do progresso das convicções intelectuais da humanidade, isto é, das leis das transformações sucessivas das opiniões da humanidade.

A questão que permanece é se esta lei pode ser determinada, primeiramente pela história como uma lei empírica e então ser convertida em um teorema científico pela dedução dos princípios da natureza humana. Como o progresso do conhecimento e as mudanças nas opiniões da humanidade são muito lentos e se manifestam de uma maneira definida, em longos intervalos, não pode ser esperado que a ordem geral da sequiência possa ser descoberta a partir de um exame de menos do que uma parte muito considerável 
da duração do progresso social. É necessário levar em consideração o todo do tempo passado, do primeiro registro da humanidade até os fenômenos da presente geração. Ou seja, é necessário efetuar uma ampla análise histórica.

\section{Panoramas da pesquisa sociológica}

A investigação que foi interpretada a partir dos escritos de Mill foi sistematicamente determinada por Comte. Segundo Mill, Comte ressalta que o conhecimento humano passou por três estágios fundamentais de progresso (que consistiria em sua lei fundamental do progresso do conhecimento humano): a) o primeiro explicou o fenômeno por casos sobrenaturais, b) o segundo por abstrações metafísicas, c) e o terceiro ou estado final se limita a determinar as leis de sucessão e similitude. Esta generalização parece ter como o mais alto grau de evidência científica que é derivada do conjunto de indicações da história aliada às probabilidades derivadas da constituição da mente humana.

Estas generalizações de Comte, conforme afirma, Mill, foram freqüentemente mal interpretadas como por Dr. Whewell, pois o primeiro estágio fundamental da humanidade que se refere ao estágio teológico não quer dizer que conforme a sociedade avança a humanidade iria deixar de acreditar em qualquer tipo de teologia, isto não está implicado em seu teorema. O que Comte quer expressar a partir de seu teorema universal é que numa fase avançada do conhecimento humano não será reconhecida outra autoridade sobre o mundo senão aquela que é governada por meio de leis universais. Dr. Whewell também entendeu mal a doutrina de Comte a respeito da fase metafísica de especulação. Comte não quer dizer que discussões metafísicas cessam quando a ciência entra em sua fase positiva. Comte refere-se à fase metafísica como quando os homens falam da natureza e outras abstrações como se fossem forças ativas, fase em que se falava que as qualidades das coisas eram tomadas erroneamente como entidades reais das coisas, fase em que nomes abstratos dos fenômenos eram tomados erroneamente pela sua existência. O que Comte quer mostrar é que a fase teológica e metafísica cede diante do avanço da ciência. 
Tanto as leis derivadas da ordem social estabelecida, como aquelas provenientes do progresso social devem ser buscadas. É interessante que se proceda em determinar quais meios (como melhoria de arranjos institucionais e educacionais) podem ser usados e qual sua extensão, para acelerar o progresso natural conforme for benéfico, para compensar suas inconveniências e desvantagens e proteger a todos contra perigos ou acidentes do progresso, aos quais a espécie humana é necessariamente exposta.

Estas instruções práticas, fundadas no mais elevado ramo da sociologia especulativa (que alia generalizações históricas que dão origem a leis empíricas fundadas em leis da natureza humana) formariam, então, a mais nobre e a mais benéfica porção da arte política e não somente da arte política, pois as leis empíricas aliadas às leis de natureza humana também representam os pilares científicos da Ética ou Ciência da Moral, como se demonstrou a partir da prova da tese hedonista, mas o mesmo poderia ser feito para extrair os outros componentes da natureza humana como o agir por hábito, como as faculdades mais elevadas, bem como a capacidade que os indivíduos têm de transformar-se ao longo do tempo. Assim, como no exemplo do hábito, aplicando-o às leis da mente, como à lei de associação, extrai-se da observação a lei empírica que as pessoas agem por hábito, então nota-se que às ações $\mathrm{A}, \mathrm{B}$ e $\mathrm{C}$ de um indivíduo $\mathrm{D}$ está associado o hábito, como o hábito é uma característica que dá constância às ações, as facilita, os indivíduos adotam, de certa forma, o hábito como uma maneira de agir (um agir sem raciocinar, sem ponderar, ou como fruto de ponderações passadas). Por uma série de deduções compara-se a proposição de que as pessoas agem por hábito, com o fato de que as pessoas agem por hábito, novamente e tem-se o teorema científico de que as pessoas agem por hábito como parte integrante da natureza humana. O mesmo tipo raciocínio poderia ser aplicado às faculdades mais elevadas e à capacidade que o indivíduo tem de transformar-se ao longo do tempo. Conforme se tem mencionado nesta tese a maneira de agir por hábito será fundamental para que se compreenda porque os indivíduos não agem apenas baseados no primeiro princípio, no princípio de utilidade, a partir do hábito é possível compreender porque os indivíduos não efetuam um balanço entre prazer e dor a todo instante quando se deparam com a moralidade dos costumes, o hábito, inscrito na natureza dos indivíduos de Mill, permite que os agentes morais se lancem na vida prática com um conjunto de regras morais, princípios secundários, que 
são fruto de decisões passadas, tomadas em conjunto com a sociedade. O hábito é um dos elementos, pertencentes da natureza do indivíduo, que permite a existência de uma moral positiva (a existência de regras morais propriamente ditas) quando comparada à moral de Bentham, uma vez que o indivíduo teórico de Bentham, a cada ato efetua um balanço entre prazer e dor, pois não possui estas características mais complexas que o indivíduo do Mill possui.

8. Afirma-se que a sujeição dos fatos históricos a leis uniformes é verificada ao rigor estatístico

No tópico passado tentou-se argumentar que o curso da história está sujeito a leis gerais que a filosofia pode detectar. Esta doutrina tem sido, há várias gerações, familiar aos pensadores científicos do continente, passando a ser popular à opinião pública, no último quarto do século XIX.

A grande novidade era a consideração de que os fatos históricos estariam sujeitos a leis científicas. O principal entrave à compreensão da doutrina de que os fatos históricos estão sujeitos a leis científicas era a doutrina do livre-arbítrio segundo a qual nenhuma lei de causalidade científica poderia ser aplicada às vontades humanas, ou seja, as ações humanas não poderiam ser previstas. Contudo, é tese deste trabalho e afirmação de Mill que as ações humanas podem ser previstas e moldadas porque são o resultado de leis da natureza humana e de circunstâncias que formam o caráter de um indivíduo. Para moldar o caráter de um indivíduo é ainda necessário que seja levado em conta os próprios esforços conscientes deste indivíduo para proporcionar circunstâncias favoráveis a ele mesmo.

"Discuti esta questão, até o ponto em que me pareceu adequado na ocasião, em um capítulo anterior e, aqui, considero necessário apenas repetir que a doutrina da Causação das ações humanas, impropriamente chamada de doutrina da Necessidade, não afirma nenhum nexus misterioso ou fatalidade absoluta: ela afirma apenas que as ações humanas são o resultado conjunto das leis gerais $e$ circunstâncias da natureza humana e do caráter particular dos homens, este caráter sendo, por sua vez, conseqüência 
das circunstâncias naturais e artificiais que constitui a educação do homem, entre as quais deve ser considerada seus próprios esforços conscientes”. [Mill, 1999, p. 132]

Se os princípios que dizem respeito aos homens individuais são verdadeiros devem ser verdadeiros para os homens coletivos, em outras palavras, as leis de natureza humana precisam ser realizadas na história (em outros termos, fica provado, mais uma vez que Mill pensa a sociedade a partir do indivíduo ${ }^{348}$. Isto quer dizer que as experiências humanas quando realizadas coletivamente precisam estar de acordo com as leis que explicam a natureza humana ou contradizê-las se forem falsas. Esta é a verificação a posteriori que representa um fundamental papel para comprovação de teorias.

Os eventos históricos que pareciam incertos e caprichosos, quando estudados com rigor estatístico, tomam um grau de regularidade matemática. Por exemplo: o número de pessoas em Londres e Paris que esquecem de colocar o endereço nas cartas enviadas em proporção às cartas enviadas ao correio é praticamente o mesmo de um ano para outro, portanto, disto extrai-se uma lei de que se pode prever para cada período sucessivo o número de pessoas cuja memória para este evento insignificante e, como poderia parecer, acidental, irá falhar ${ }^{349}$. Este caso compõe uma feliz verificação $a$ posteriori da lei de causação na sua aplicação à conduta humana.

Outro exemplo interessante que Mill descreve como se dá um assassinato. De acordo com o autor, o assassinato é o resultado combinado de dois grupos de causas. O primeiro grupo de causas decorre das circunstâncias gerais do país e de seus habitantes, das influências morais, educacionais, econômicas, e todas aquelas que operam sobre a totalidade da população e que compõem o que se denominada estado de civilização, o segundo grupo de causas inclui a variedade de influências especiais do indivíduo, a saber: seu temperamento e outras peculiaridades de sua organização, seu parentesco, suas relações habituais, tentações e assim por diante. Caso estas combinações ocorrerem em um limite de tempo estreito o bastante para que nenhuma mudança essencial opere nas influências gerais, então pode-se dizer que as ações humanas são dirigidas por leis invariáveis. Como o número de assassinatos cometidos naquele limite de tempo e espaço

\footnotetext{
${ }^{348}$ Mill, (1843), 1999, p.132

${ }^{349}$ Mill, (1843), 1999, p. 133.
} 
é o efeito de causas gerais que não variam e ao mesmo tempo o efeito de variações de causas parciais foram inclusas, o fenômeno será, praticamente, invariável. Este número tanto, não é literalmente e matematicamente invariável, pois o período de um ano é suficientemente longo para tornar provável que ao menos novas influências de um caráter geral da série tenham acontecido, como uma polícia mais forte ou alguma excitação produzida por causas políticas. Contudo, mesmo que existam alterações nos dados, a margem de alteração nos mesmos é pequena, o que significa que há uma forte confirmação da teoria.

9. A Sujeição dos fatos históricos a leis uniformes não implica a insignificância das causas morais.

É possível depreender dos escritos de Mill que, por exemplo, cada assassinato particular não depende apenas do estado geral da sociedade, mas deste estado combinado com causas especiais ao caso, causas que são geralmente, muito mais poderosas. Muitos, inclusive Buckle, ressalta Mill, cometeram o erro de sobrecarregar suas teorias com causas gerais às custas das especiais. Buckle afirmou que as qualidades morais são pouco suscetíveis de aperfeiçoamento quando comparado às causas intelectuais e econômicas para o aperfeiçoamento do progresso geral da sociedade. Entretanto, realizar estas afirmações, de acordo com Mill, é esquecer que estes fatos ocorrem em limites geográficos estreitos e em um pequeno número de anos para permitir mudanças.

De acordo com Mill, os crimes cometidos em um país devem depender de suas qualidades morais coletivas. Segundo Mill, o elemento intelectual da humanidade, como a soma dos conhecimentos e o desenvolvimento da inteligência de um povo, compõe a circunstância predominante para direcionar o progresso deste mesmo povo. Os fatores econômicos e morais são conseqüências da condição intelectual e são limitados por esta condição. As mudanças intelectuais são os fatores 
mais proeminentes na história, não por sua força superior considerada em si mesma, mas porque operam com as forças reunidas de todos ${ }^{350}$.

"De fato, não poderia ser de outra forma pois, assim como todo crime particular cometido por um indivíduo depende principalmente de suas qualidades morais, os crimes cometidos pela população inteira do país deve depender, no mesmo grau, de suas qualidades morais coletivas". [Mill, 1999, p. 135] "Entretanto, não estou menos de acordo com a opinião do Sr. Buckle segundo a qual o elemento intelectual na humanidade, incluindo-se nesta natureza das crenças, a soma dos conhecimentos $e$ o desenvolvimento da inteligência, é a circunstância predominante na determinação do progresso". [Mill, 1999, p. 135].

Desta forma, a sujeição de fatos históricos a leis uniformes não implica a insignificância de causas especiais, implica muitas vezes que há importância de causas especiais. Além disso, torna-se fundamental verificar a importância que o elemento faculdades mais elevadas assumem no modelo de indivíduo teórico de Mill, uma vez é a essas faculdades mais elevadas que o indivíduo deve seus prazeres de qualidade mais elevada e parece ser o fato dos indivíduos sentirem prazeres mais elevados ao valorizarem elementos como o desenvolvimento intelectual, artístico e do conhecimento em geral a própria causa de seu progresso, o próprio guia que pode levá-lo a um estado mais feliz. Em outras palavras, este novo elemento da natureza humana, quando comparado ao indivíduo teórico de Bentham, denominado faculdades mais elevadas dá origem ao motor do progresso humano (prazeres de qualidade superior que estão associados a atividades e contemplações humanas, como a o acúmulo de conhecimento, apreciação artística, simpatia para com os outros, amor à virtude, à fazer o bem, a fazer convergir seus interesses para os da sociedade).

\footnotetext{
${ }^{350}$ Mill ressalta que Buckle aceitaria suas considerações, apenas as relegou a um segundo plano, porque considerou que era melhor exagerar a influências das causas gerais em detrimento das especiais e particularmente, às custas da influência das mentes individuais. Sua intenção real não era mais do que afirmar que os grandes homens não podem efetuar mudanças importantes nos acontecimentos humanos a menos que a mente geral esteja, em uma medida considerável, preparada para elas pelas circunstâncias gerais da época.
} 
10. A sujeição dos fatos históricos a leis uniformes não implica a ineficácia do caráter dos indivíduos e dos atos do governo

Muitas pessoas que sustentam a teoria de que o progresso está sujeito a leis invariáveis, defendem que o progresso social não pode ser influenciado pelos esforços de pessoas individuais ou pelos atos do governo. A confusão consiste no freqüente erro de misturar-se causalidade e fatalismo. As vontades dos indivíduos podem ter grandes efeitos nas causas mesmo que o progresso social seja submetido a leis invariáveis. Por exemplo, se alguém em uma tempestade em alto mar concluir que é inútil tentar salvar a própria vida porque a cada ano morre por naufrágio o mesmo número de pessoas, poderse-ia chamar esta pessoa de fatalista.

$\mathrm{O}$ que depende das peculiaridades dos indivíduos combinados com as posições acidentais em que estes se encontram não é passível de ser captado por previsão [Mill, (1843), 1999, p. 139]. Tomando-se um período longo estas combinações causais podem ser eliminadas. Segundo uma interpretação que se pode fazer a partir dos escritos de Mill, não se pode prever o advento dos grandes homens. Aqueles homens que introduzem no mundo novos pensamentos especulativos ou grandes concepções práticas não podem ter sua época fixada de antemão. [Mill, (1843), 1999, p. 139] A ciência pode investigar quais foram as causas, a conjunção de circunstâncias que tornou possível o advento daquele homem. Caso as circunstâncias continuarem a ser favoráveis, o advento de homens eminentes continuará a ocorrer.

É afirmado por Mill que é a existência de grandes homens que decide se haverá algum progresso nas teorias [Mill, (1843), 1999, p. 138]. Entretanto, de acordo com o autor, a determinação do modo e da ordem em que o progresso da humanidade ocorrerá, depende muito menos do caráter dos indivíduos. "Há, a este respeito, um tipo de necessidade estabelecida pelas leis gerais da natureza humana, pela constituição da mente humana” [Mill, (1843), 1999, p. 138]. Desta forma, o caráter humano é bastante importante para determinar o progresso de teorias, embora não seja fundamental para determinar a maneira e a ordem de como se dá tal progresso.

Portanto, o resultado do progresso continua podendo ser submetido à lei de causalidade. A regularidade do progresso pode ser submetida à lei ainda que os atos do 
governo e de homens eminentes surtam muita ou pouca eficácia sob os resultados do progresso. $\mathrm{O}$ mesmo pode ser afirmado a respeito de outras causas perturbadoras.

11. A importância histórica dos homens eminentes e da ação política dos governos esclarecidos

Não é porque as circunstâncias gerais e o curso da história não prepararam a sociedade para receber a influência de homens eminentes (tais como pensadores) e de atos do governo que se deve concluir que a influência de ambos é pequena. Ao contrário, é possível interpretar que Mill atribui importante influência a ambos, pois o autor afirma que ambos produziram, freqüentemente, importantes resultados não previstos. Conforme menciona Mill: “Os grandes homens e as grandes ações raramente são estéreis: elas lançam milhares de influências invisíveis, mais efetivas do que as visíveis" [Mill, 1999, p. 140]. Mesmo homens que não deixaram nenhuma influência sobre sua época, acabam produzindo efeitos bastante interessantes para as épocas posteriores. Os heréticos seriam pessoas que teriam vivido em vão, caso não se pudesse enxergar o rompimento com a tradição que eles ocasionaram, o fato de que a resistência deles inspirou coragem nos reformadores posteriores. Faz-se, então um paralelo com o que os governos podem fazer por uma nação. Toma-se o exemplo da Espanha e conclui-se que o governo comparativamente proveitoso do século XVIII desempenhou diversos avanços no sentido liberal, em meio século. Ao mesmo tempo, o esclarecimento do pensamento europeu nas classes mais cultas não cessou de se propagar. De acordo com Mill, a cultura, as luzes e até mesmo a atividade intelectual estavam extinguindo-se antes daquele governo [Mill, (1843), 1999, p. 141]. Então, o autor pergunta se não terá sido algo deter este ciclo retrógrado e convertê-lo em um ciclo progressivo. "Quantas coisas Charles, o Terceiro e Aranda não puderam fazer foram as conseqüências últimas do que fizeram!” Naquele meio século a Espanha livrou-se da Inquisição e dos monges, adquiriu uma imprensa, um parlamento (que salvo em intervalos excepcionais era livre) e passou a ostentar sentimentos de liberdade e de cidadania.

De acordo com Mill é possível afirmar: "a ciência histórica não autoriza previsões absolutas, mas apenas condicionais" [Mill, 1999, p. 142]. “As causas gerais 
contam em muito, mas os indivíduos também produzem grandes mudanças na história" Segundo Mill, ninguém duvida que a República romana teria caído sob o despotismo militar mesmo que Júlio César tivesse vivido (resultado praticamente certo pelas causas gerais).

Entretanto, "Ainda que o curso dos acontecimentos nunca cesse de ser suscetivel de alteração, tanto por acidentes como pelas qualidades pessoais dos indivíduos, a crescente preponderância da ação coletiva da espécie sobre todas as causas menores está constantemente conduzindo a evolução da humanidade para algo que se desvia cada vez menos de uma via certa e previamente estipulada" [Mill, (1843), 1999, p. 143]. A ciência histórica é cada vez mais estudada não só porque a cada geração torna-se mais própria para o estudo, mas porque tem sido melhor estudada. Desta forma, conclui-se que a ação de homens eminentes e a ação de governos são importantes para o rumo da história, mas no efeito geral da ciência quando contrapostas à causa gerais, estas contam como o curso ordinário da história, e aqueles como os desvios, ainda que de fundamental importância.

3.9 A Moralidade é uma arte que deve ser embasada em uma ciência.

1. A Moralidade não é uma ciência, mas uma Arte (dita preceitos).

As investigações que se expressam no modo imperativo (como não matarás ou não roubarás) devem ficar inclusas à arte denominada moral, porque dita preceitos e não podem ser denominadas de conhecimento científico, propriamente dito, mas ao contrário, devem estar embasadas em um conhecimento científico. É o que se chama de conhecimento dos deveres, ética prática ou moralidade. $\underline{\mathrm{O} \text { modo imperativo é }}$ característico da arte, é o modo que diz respeito à moralidade (dita preceitos: faça isto não faça aquilo) e deve estar embasado em uma ciência. A ética ou moralidade é a parte da arte que se fundamenta nas ciências da natureza humana. Tudo que se exprime em 
regras ou preceitos e não em proposições acerca de questões de fato é denominado arte [Mill, 1999, p.145]. ${ }^{351}$

Uma questão de fato pode ser expressa através da seguinte proposição: que as pessoas buscam o prazer e fogem da dor e que o prazer é um bem em si e a dor um mal em si. Esta pode ser denominada uma lei empírica válida dentro dos limites da observação e transformada em lei etológica ou causal da seguinte forma: considerando esta lei empírica, a lei da indução e as leis de associação. Tem-se que à uma ação A associa-se um prazer $\mathrm{K}$, a uma ação $\mathrm{L}$ associa-se um prazer $\mathrm{M}$, a uma ação $\mathrm{C}$ associa-se um prazer $\mathrm{N}$ e assim consecutivamente. Se estas ações foram realizadas sucessivamente à idéia de um prazer $\mathrm{K}$ remonta à idéia dos outros prazeres que pode fazer com que o agente busque realizar as ações $\mathrm{A}, \mathrm{L}$ e $\mathrm{C}$ novamente porque a essas ações estão associadas idéias de prazeres que são agradáveis, se fossem dores o agente procuraria não agir naquela direção, uma vez que a dor é desagradável. Por deduções realiza-se a comparação do que foi encontrado com as combinações da lei da mente e verifica-se novamente com a lei empírica: que os homens buscam o prazer e fogem da dor porque o prazer é um bem em si e a dor um mal em si e assim prova-se a tese hedonista. A tese hedonista sendo um componente da natureza humana ao qual todos os outros componentes são derivados (como o agir por hábito, as faculdades mais elevadas que derivam prazeres mais elevados, a capacidade do indivíduo transformar-se ao longo do tempo), com exceção das leis lógicas, leis da mente que são um componente da natureza humana, mas não derivam da tese hedonista. Deste teorema da ciência ou da natureza humana do indivíduo do Mill, converte-se o primeiro preceito da moralidade utilitarista também de Mill, a saber: que é correto buscar o prazer e errôneo buscar a dor, a diferença do princípio de utilidade de Mill para com o de Bentham é que muitas outras coisas precisam ser ditas para que se compreenda a idéia de prazer e dor, para Mill (como por exemplo, o fato de que existem prazeres de qualidade mais elevada quando comparados a prazeres de qualidade menos elevada relativamente aos prazeres apenas quantitativos de Bentham, o fato de que os indivíduos podem agir por hábito e isto dá constância às ações morais, criando a possibilidade da criação de princípios secundários, como o agir de

\footnotetext{
${ }^{351}$ Observa-se que há outro significado da palavra Arte, do qual pode-se dizer que denota a parte ou o aspecto poético das coisas em geral, por oposição ao aspecto científico. No texto, a palavra é empregada em seu sentido antigo.
} 
acordo com a moralidade dos costumes que são regras da ética decididas no passado, embora embasadas no princípio da utilidade e o fato de que indivíduos podem transformar-se ao longo do tempo).

Uma questão que poderia ser formulada diz respeito a: o fato dos indivíduos possuírem uma característica em sua natureza denominada capacidade de transformação ao longo do tempo não implicaria em revisão das regras da ética a todo instante assim como o indivíduo do Bentham o faz? A resposta é negativa, pois, conforme é tese deste trabalho e é argumento de Mill, os indivíduos mudam, transformam-se, mas essas mudanças não são operadas em cada ação, de acordo com um balanço entre prazer e dor, tal balanço pode ser efetuado, para que as regras dos costumes iniciais sejam escolhidas, bem como quando há conflito moral entre elas, contudo, o sentido de mudança dos indivíduos que quer dar-se aqui é um tipo de mudança gradual que diz respeito ao fato dos indivíduos poderem aprimorar seus caracteres, seja como uma tentativa de escolher as circunstâncias que o afetarão (dentro de determinadas possibilidades), seja quando são afetados por circunstâncias sociais derivadas dos arranjos institucionais vigentes.

Voltando à questão da ética sabe-se que o campo da prática, da arte compõe a ética. Contudo, é importante diferenciar o método da arte como distinto do método da ciência. É necessário que não haja engano, pois há uma relação necessária das regras da arte com os teoremas da ciência correspondente. No ramo da atividade prática, há casos em que os indivíduos precisam descobrir suas próprias regras que conduzirão seu caráter ou já encontram essas regras prontas.

De acordo com Mill: “As razões de uma máxima de ação política ou de qualquer outra regra de arte só podem ser os teoremas da ciência correspondente" ${ }^{352}$. [Mill, 1999, p. 146]. Os teoremas da ciência não estão preparados para serem convertidos em preceitos da arte até que as operações que pertencem à ciência estejam completas.

\footnotetext{
${ }^{352}$ Mill ressalta que as relações que as regras da arte mantêm com a ciência são da forma silogística: a arte empresta à ciência um fim a ser atingido (a premissa maior). A ciência o recebe como um fenômeno a ser estudado e tendo estudado suas causas, envia-o à arte em conjunto com um teorema sobre a combinação de circunstâncias das quais poderia ser produzido. A arte fornece a premissa maior de que determinado fim é desejável, a ciência empresta à arte a proposição (obtida por uma série e deduções e induções) segundo a qual desempenhar determinadas ações levará ao determinado fim. Analisando estas premissas a arte conclui que realizar as determinadas ações é desejável, sendo as ações também praticáveis, o teorema passa a ser convertido em preceito. Mill, afirma que as regras da arte mantêm uma relação silogística com a ciência, mas não fornece exemplos.
} 
Pode ocorrer que o procedimento científico tenha sido efetuado até certo ponto em que a causa de um determinado efeito seja descoberta, mas que não se tenha descoberto todas as circunstâncias que os casos presentes impediriam sua produção. Este poderia ser denominado um estado imperfeito da teoria. Se neste estado da teoria, fosse tentado converter o teorema em preceitos da arte, as regras da arte seriam defeituosas, porque meios defeituosos estariam sendo empregados para extrair as regras da arte. A única saída viável seria, então, voltar à teoria e concluir o procedimento científico, determinando todas as circunstâncias que poderiam impedir a causa do efeito científico e só após converter o teorema científico em preceitos da arte. Portanto, conclui-se que é só depois de determinar todas as condições e circunstâncias das quais o efeito depende que os teoremas de uma ciência podem ser convertidos em arte, preceitos.

Contudo, Mill ressalta que por razões de comodidade as regras da arte podem ser formadas por algo menos do que a teoria idealmente perfeita, primeiro porque é difícil obter a teoria perfeita, com todas as contingências contrárias que influenciam as causas de um efeito, dado o complexo fenômeno social (aquilo que se obtém são sempre tendências e conhecimentos hipotéticos) e segundo porque as regras da arte não pretendem abranger mais condições do que aquelas que são necessárias observar nas ocasiões comuns da vida. Por exemplo, quanto as artes manuais nem sequer é necessário o conhecimento de uma ciência para a aplicação das regras das artes. Contudo, nos assuntos que dizem respeito à sociedade, como à moralidade, as regras da arte precisam referir-se, constantemente, às ciências nas quais se fundam. Ter conhecimento das contingências práticas que demandam uma modificação da regra ou que compõem suas exceções constitui o mesmo que conhecer as combinações de circunstâncias que gerariam influência nas consequiências das leis científicas e isto só pode ser conhecido referindo-se às bases teóricas da ciência. Um bom exemplo refere-se à moralidade, é interessante saber que a o princípio de utilidade, primeiro princípio da moralidade utilitarista, que funda a moralidade utilitarista (e está de acordo com a natureza humana (tese hedonista) de que o homem busca o prazer e foge da dor e prazer e dor tem valores intrínsecos), ressalta que uma ação é correta na medida em que tende a promover a felicidade e errônea na medida em que tende a gerar dor, ou a produzir o reverso da felicidade, entendendo-se por felicidade prazer. Deve-se entender que este princípio está fundado em 
uma ciência, uma ciência da natureza humana que prova que os homens de fato estão sujeitos à busca do prazer e à fuga da dor, que prazer e dor são componentes da natureza humana, que buscar o prazer é agradável e buscar a dor é desagradável, conforme tem-se descrito é possível provar esta proposição, pois um indivíduo ao realizar uma ação A tem por associação um prazer $\mathrm{B}$, ao realizar uma ação $\mathrm{C}$ tem por associação um prazer $\mathrm{D}$, ao efetuar uma ação E tem como resultado um prazer $\mathrm{F}$, sendo que todas estas ações foram realizadas sucessivamente, quando se pensa a idéia de um destes prazeres a idéia dos outros prazeres retorna e são idéias agradáveis fazendo com que as ações correspondentes sejam realizadas novamente, o contrário ocorreria para a dor uma vez que a idéia ou o estado mental, sentimento provocado pela dor é desagradável e assim as ações correspondentes às dores cessariam de ser efetuadas. É importante que se conheça a ciência porque as pessoas buscam a felicidade ou prazer, mas há outras circunstâncias que podem fazer com que as pessoas busquem outras coisas e que esta primeira proposição que dá origem ao primeiro princípio da natureza humana não explique, como quando uma pessoa pense que deve ser parte da formação de seu caráter apreciar a arte. É tese deste trabalho que os objetivos que não tiverem auxílio da tese hedonista, tem auxílio das outras características da natureza humana aqui identificadas como (o agir por hábito, as faculdades mais elevadas que dão origem a prazeres mais elevados e a capacidade que o indivíduo tem de se modificar ao longo do tempo), lembrando que estas características derivam seu valor da busca da felicidade e portanto da tese hedonista, estando, portanto, subordinadas a elas. Assim, voltando ao indivíduo que pense que para a formação de seu caráter deva buscar a apreciação da arte, este seria um princípio secundário com base no princípio primeiro da utilidade, com fundação na ciência (o primeiro princípio que as pessoas buscam o prazer e fogem da dor e o secundário também tem fundamento na busca da felicidade), mas tem fundamento mais imediato no fato de que as pessoas possuem faculdades mais elevadas relativamente a faculdades menos elevadas que dão origem a prazeres de qualidade mais elevada como a apreciação da arte (no sentido contemporâneo do termo).

No utilitarismo de Mill, as regras da moralidade, princípios secundários, são mais fundamentais para que se atinja a felicidade do que no utilitarismo de Bentham, justamente porque Mill reconhece, acertadamente, que a natureza humana é mais 
complexa do que a natureza humana descrita por Bentham. As regras da moralidade apontam a maneira pela qual será menos perigoso agir quando não há meios ou tempo para analisar as circunstâncias reais do caso, ou quando decisões passadas já foram deliberadas, tomadas sabiamente. Contudo, elas não anulam, nos casos em que as circunstâncias requerem, o procedimento científico para a formação da regra científica e após para a formação da regra moral, ou seja, o princípio da utilidade, o primeiro princípio também pode ser chamado para decidir sobre a elaboração de regras morais, em casos em que as circunstâncias o requisitam, como no caso de conflito entre princípios secundários. Portanto, a regra secundária, relativamente ao primeiro princípio (o princípio da utilidade) é um reconhecimento de que uma determinada ação foi reconhecida, pelas pessoas, como muito bem adaptada aos casos morais de ocorrência mais comuns.

\begin{abstract}
"Ao mesmo tempo, a regra comum pode, muito propriamente, servir para nos advertir que um modo de ação foi reconhecido, por nós e por outros, como muito bem adaptado aos casos de ocorrência mais comum, de modo que, se ele for inadequado para o caso em questão, a razão deve se encontrar, provavelmente, em alguma circunstância excepcional."[Mill, (1843), 1999, p. 148]
\end{abstract}

Deve-se levar em conta, entretanto, que a arte não deve ser dedutiva. É, desta forma, bastante evidente o erro daqueles que deduzem os preceitos da arte de preceitos universais da arte, sem considerar que a arte deve estar embasada na ciência, especialmente as artes referentes à sociedade (à política, à moralidade), as artes que não prescindem de tanta referência à ciência referem-se mais às artes manuais. Um erro maior seria instituir princípios absolutos como regras universais sem considerar que há a possibilidade de causas modificadoras impedirem a obtenção de determinado fim pelos meios prescritos pela regra. Sempre é necessário considerar as circunstâncias que rodeiam as regras da arte, pois pode figurar como uma causa modificadora impedindo a obtenção de um determinado fim pelos meios que a regra coloca, ou um fim colocado por uma regra prática (princípio secundário em moralidade) pode entrar em conflito com outro fim colocado por outra regra prática (outro princípio secundário em moralidade), 
sendo necessário chamar o princípio primeiro (em moralidade) para solucionar casos de conflito moral.

Este é o erro de muitos da escola geométrica, especialmente na França, conforme afirma Mill. Na França, os lugares comuns da política seriam máximas práticas vastas e abrangentes que seriam tomadas como premissas últimas para deduzir delas as aplicações particulares; a isto seria chamado de ser lógico e consistente. Por exemplo, argumentar-se-ia que determinada medida deveria ser adotada porque é uma consequiência do princípio no qual está fundada a forma de governo, o princípio de legitimidade ou princípio de soberania popular. Contudo, estes são princípios práticos que devem repousar sob bases científicas. $\mathrm{O}$ argumento de Mill em relação à adoção do modelo geométrico na França é o de que lá se toma equivocadamente por filosofia política a conclusão prática de que se deveria fazer o máximo esforço para corrigir, e não para esconder, as imperfeições características, quaisquer que sejam, do sistema de instituições sob o qual se vive. A crítica de Mill aos cientistas sociais franceses é que eles não vão às causas, à ciência para ajustar suas asserções e assim parece que desejam agravar o sistema de imperfeições institucionais.

Alguém poderia indagar se os princípios secundários não deveriam ser proibidos de estar fundados no princípio da utilidade, afinal o princípio da utilidade é um preceito e neste caso uma arte estaria fundada sobre uma arte. A resposta é simples, não há problema dos princípios secundários terem como fundamento o princípio da utilidade, pois tais preceitos estão indiretamente embasados na ciência, uma vez que o primeiro princípio é fundado na ciência, além disso, caso deseje-se extrair os princípios secundários, diretamente da ciência, em combinação com as leis da mente sempre será feita uma associação com a felicidade (prazer) ou infelicidade (dor) e, portanto, é mais prático que se use o princípio da utilidade para embasar a moralidade, uma vez que este princípio é uma regra de ação convertida da ciência.

Portanto, conclui-se que toda arte deve estar embasada em verdades da ciência arranjadas em uma ordem adequada para uso prático. É, desta forma, nos teoremas da ciência que devem ser embasadas as regras da arte. A ciência tem por objetivo agrupar suas verdades de modo a permitir abranger a maior parte possível a ordem geral do universo, enquanto a arte, assumindo as mesmas leis gerais, segue suas 
conseqüências para levar à formação de regras de conduta. A arte converte dos teoremas das verdades das ciências preceitos requeridos pela vida prática.

"A arte, ainda que deva assumir as mesmas leis gerais, segue-as apenas naquelas suas consequências detalhadas que levam à formação de regras de conduta, trazendo, das partes do campo da ciência que são as mais remotas entre si, as verdades relacionadas à produção das diferentes $e$ heterogêneas condições necessárias para cada efeito que é requerido pelas exigências práticas". [Mill, 1999, 150].

Desta forma, a ciência tenta elencar as leis causais dos efeitos, enquanto a arte utiliza tais efeitos para formular prescrições na vida prática. O princípio de utilidade que ressalta ser correto buscar a felicidade ou o prazer e errôneo buscar a dor e que no caso de Mill aponta para o fato de que muitas outras coisas precisam ser ditas para que se entenda a felicidade, isto quer dizer que, em moralidade há mais espaço para a formulação de regras morais, pois a própria formulação do princípio de utilidade de Mill aponta para o fato de que se guiar, no mundo, com apenas o primeiro princípio, não é suficiente. Desta forma, princípios secundários de ação estão presentes na moralidade do utilitarismo de Mill, eles são as prescrições da vida prática, derivadas do princípio primeiro e só possíveis porque o método de fazer ciência de Mill (dedutivo concreto da física, indutivo não geométrico excessivamente abstrato) é mais completo, deriva uma natureza humana mais complexa (com leis da mente, a tese hedonista, e outros elementos subordinados à tese hedonista como faculdades mais elevadas, o agir por hábito e a capacidade que o indivíduo tem de transformar-se ao longo do tempo). Desta natureza humana mais complexa é que se deriva este princípio de utilidade mais complexo que aponta para o fato de que a busca do prazer e dor sem nenhuma qualificação não são suficientes, é necessário que se explique de que forma eles são buscados e é precisamente nesta forma de busca dos prazeres e das dores, na relação do indivíduo consigo mesmo e com o outro que há espaço para a formulação de outras regras morais que não apenas o princípio da utilidade, que há espaço para a formulação de princípios secundários como não roubarás, não matarás, aprecie a arte, etc. Lembrando que estes preceitos estão ancorados no primeiro princípio moral (o de utilidade) que está embasado nos teoremas 
de uma ciência (que as pessoas buscam prazer e dor, como a tese hedonista central, que associado a isto, têm-se as faculdades mais elevadas, a capacidade de transformar-se ao logo do tempo e o agir por hábito ${ }^{353}$ ). Deve-se lembrar sempre que quando se faz ciência social há um conjunto de verdades mais altas que são as verdades mais abstratas obtidas por indução e deduções e verificação com leis empíricas, no modelo de indivíduo aqui traçado estas leis mais altas seriam as leis da mente (toda impressão mental tem sua idéia, leis de associação e freqüência de conjunção), as leis do meio ou leis etológicas, mas não menos leis da natureza humana ressaltariam que todo homem busca o prazer e foge da dor e este comporia um dos mais fortes motivos de ação dos homens, entretanto, é observado que os homens também agem por hábito, também possuem faculdades mais elevadas, também transformam seu caráter com o passar do tempo, embora todos esses elementos da natureza humana derivem seu valor do benefício que trazem aos indivíduos, da tese hedonista. $\mathrm{O}$ fato do indivíduo apresentar mais elementos que expliquem sua natureza relativamente a Bentham (seu agente possuindo apenas a busca pelo prazer e a fuga da dor) estão plenamente de acordo com a maneira como Mill pensa fazer ciência, uma ciência que contemple mais elementos, mais explicações que inclua elementos circunstancias em suas explicações (através da verificação), abrangendo leis causais do fenômeno mais próximas aos fatos, menos abstratas e, portanto, longe dos fatos. Da tese hedonista deriva-se o princípio de utilidade (converte-se uma ciência em um preceito moral, o primeiro, dado que se considera a tese hedonista como o principal motivo de ação humano), dos outros componentes da natureza humana percebe-se que é possível derivar um princípio da utilidade diverso daquele em relação à Bentham, pois muito mais coisas precisam ser ditas para que se entenda a felicidade ${ }^{354}$, ainda que o objetivo seja a felicidade, conscientemente ou inconscientemente. Da possibilidade de poder explicar a felicidade não apenas em termos de prazer, mas com outras partes ${ }^{355}$ associadas ao prazer, surge a possibilidade de uma moralidade com regras que não serão questionadas a todo instante por um homem calculador, por um homem que é dotado de uma razão calculadora que faz cálculos a todo instante, que avalia se a regra deve ser seguida ou

\footnotetext{
${ }^{353}$ Todos esses elementos da natureza humana derivam seu valor do prazer ou do benefício que geram para o indivíduo uma vez que ajudam no melhoramento do caráter do indivíduo e mesmo da sociedade.

${ }^{354}$ Mill, 1861, p. 55 (2.2).

${ }^{355}$ Mill, 1861, p.235 "O que de início se desejava como um instrumento para alcançar a felicidade passou a ser desejado por si mesmo. Porém, ao ser desejado por si mesmo, é desejado como parte do prazer”.
} 
não, da possibilidade da existência de uma moralidade, surge a possibilidade do estabelecimento de regras fixas (como não matar, não roubar, estudar, apreciar a arte, etc) com as quais o agente se lança no mundo e apenas modifica à luz do princípio da utilidade em caso de conflito dos princípios secundários, ou conforme ele apura seu caráter. Este homem é dotado do hábito, elemento de sua natureza fundamental para que ele possa agir de acordo com decisões passadas, sem precisar agir roboticamente, como o indivíduo teórico de Bentham.

Há que se notar que o que é denominado aqui de princípios secundários (regras da moralidade ancoradas no princípio da utilidade) não é o mesmo do que os princípios do meio (ou leis etológicas) a natureza dos princípios intermediários ou do meio deve ser formar a concepção mais compreensiva da natureza humana de que se pode dispor. Quando o resultado deste exame for reunido em proposições pouco numerosas e pouco extensas quanto possível, estas proposições expressarão a relação geral entre os meios disponíveis e o fim. Esta então constituirá a teoria científica geral da Arte, da qual se seguirão, como corolários, seus métodos práticos. 


\section{Conclusão do Capítulo III}

Portanto, de tudo que foi exposto, em linhas muito breves, conclui-se que uma ciência deve ser sempre a base de uma arte ou ditar os corolários, preceitos da arte, conforme afirmou-se no início deste trabalho. É possível sim fazer uma ciência da natureza humana, é possível realizar uma ciência social. É possível efetuar uma ciência política, uma ciência do caráter nacional ou da etologia política, uma ciência da economia, uma ciência geral da história, uma ciência que embasa a moral, uma ciência que embasa a formação do caráter humano; seja ela denominada ética ou ciência moral. Entretanto, como formula-se esta ciência? Tratou-se aqui, conforme as nomenclaturas utilizadas por Mill, de métodos errôneos considerados por este autor para efetuar-se ciência, como o método químico (argumentando que o indivíduo em sociedade não se transforma em outra coisa além do que ele é (como o hidrogênio se mistura com o oxigênio e transforma-se em água), em outras palavras as leis de sua natureza são preservadas mesmo com o homem em sociedade porque se pensa a sociedade a partir do indivíduo, apesar das circunstâncias terem um papel fundamental para a formação do caráter do indivíduo, além disso seria impossível e mesmo moralmente condenável realizar experimentos controláveis assim como efetua-se em química), outro método errôneo para ser utilizado em ciências sociais seria o método geométrico, primeiro porque alguns dos cientistas que se utilizam deste método, fundam uma ciência com base em preceitos de uma arte, como seria o caso de Hobbes, de acordo com Mill ${ }^{356}$ e segundo porque outros cientistas sociais fundam sua teoria em poucas premissas ou apenas uma abstração, ficando demasiado longe da explicação do complexo fenômeno social, como é o caso de Bentham com seu utilitarismo. Para compor a Ética ou a Ciência da Moral que embasa as regras da moralidade, para provar a tese hedonista, a proposição de que os indivíduos buscam o prazer e fogem da dor tomou-se a lei empírica da qual a observação

\footnotetext{
${ }^{356}$ Reste claro que esta tese não está de acordo com a opinião de Mill de que Hobbes funda a base de uma ciência política em uma arte, apenas porque prescreve o contrato original. Entende-se que o contrato original está fundando em uma ciência da natureza humana, tais como afirmações sobre os indivíduos, a saber: que eles são iguais, dotados de uma razão calculadora, de determinadas paixões e desejam e perseguem fins que podem ser conflitantes, daí surge a discórdia e a necessidade de passar do estado de natureza ao Estado Civil, por meio de um pacto.
} 
é originalmente oriunda, combinou-se às leis da mente (obtidas por indução) depois realizou-se uma série de deduções, segundo mostrou-se que de é fato é agradável buscar o prazer (tem valor intrínseco como fim em si) e desagradável buscar a dor e corroborouse com a experiência novamente. Este método é o dedutivo inverso, porque primeiro parte-se de uma lei empírica que atravessa os tempos que os homens buscam a felicidade (parece ser uma lei histórica), para depois combiná-la às leis mais altas. Além disso, Ética ou ciência da moral permite que outras causas expliquem a formação da natureza humana (como hábito, capacidade de desenvolver o caráter ao longo do tempo, faculdades mais elevadas, todas subordinas ou associadas, entretanto, à tese hedonista, conforme discutiuse). O procedimento científico para que se chegue a cada característica da natureza humana como o hábito é o mesmo feito para provar a tese hedonista. A diferença é que os outros elementos da natureza humana estariam associados à tese hedonista. No exemplo dado anteriormente do hábito, da lei empírica de que as pessoas agem por tal elemento e utilizando-se a lei de associação, um indivíduo poderia efetuar uma ação A,B,C por hábito e a estas ações efetuadas por este componente da natureza humana poderia estar associada uma certa conveniência de se agir desta forma, realiza-se uma dedução mostrando-se que as pessoas realmente agem por hábito porque há conveniência nestas ações e depois verifica-se à lei empírica de que de fato as pessoas agem de acordo com esse componente, provando-se que as pessoas agem por hábito. Enfim, todas as características da natureza humana do modelo de indivíduo que se defende neste trabalho poderiam ser mostradas desta forma. Segue-se disso que o modelo de indivíduo é expresso, então, pelas leis da mente, tese hedonista (que o indivíduo possui estados mentais ligados a prazer e dor e busca o prazer e foge da dor) e outros elementos que derivam seu valor da felicidade, como o agir por hábito (que permite que o indivíduo não efetue cálculos a todo instante e, portanto, possa desligar-se do cálculo, no momento da ação, do princípio de utilidade e agir conforme princípios secundários, conforme a moralidade dos costumes), faculdades mais elevadas que derivam prazeres de qualidade elevada e a capacidade que o indivíduo tem de se transformar ao longo do tempo (tanto por circunstâncias de sua escolha dentro de certas possibilidades, quanto por circunstâncias relacionadas a arranjos institucionais, educacionais, especialmente favoráveis). Apresenta-se a seguir a Ética de John Stuart Mill. 


\section{Capítulo IV - A Ética no Utilitarismo de Mill}

\section{A ética no utilitarismo de Mill}

Para que se entenda a ética no utilitarismo de Mill é necessário compreender o modelo de indivíduo que se pode depreender a partir dos escritos do autor, pois em última instância, pode-se afirmar que o que existe para o autor, para análise política e moral é o indivíduo, sendo a sociedade uma composição desses agentes, embora, o autor reconheça, que para formação do caráter (etologia, em suas palavras) destes mesmos indivíduos, seja fundamental a existência de arranjos institucionais sociais, educacionais $^{357}$, que propiciem a convergência dos interesses individuais com os coletivos. Abaixo cita-se uma passagem na qual resta claro sua noção de sociedade como soma de felicidade dos indivíduos:

"Mas não é de modo nenhum, uma condição indispensável para a aceitação do modelo utilitarista pois esse modelo não é a maior soma da felicidade do próprio agente, mas a maior soma de felicidade conjunta”. [Mill, 1861, p. 196]

$\mathrm{O}$ modelo de indivíduo no que diz respeito à moral, foi defendido no capítulo anterior como constituindo um modelo dinâmico, pois uma das características fundamentais da natureza deste indivíduo é a capacidade de se transformar ao longo do tempo. Note-se que esta capacidade de se modificar ao longo do tempo, presente na natureza do agente, deriva seu valor do fato de poder gerar felicidade ou prazer ao indivíduo que age. Todas as características presentes na natureza humana (que tornam o indivíduo teórico de Mill mais complexo, relativamente ao indivíduo teórico de Bentham) derivam seu valor ou são requisitos para que os indivíduos busquem a felicidade, quando se pensa em uma ciência da moral ou em uma ética que converte os teoremas da ciência em regras de conduta para a moralidade. Além da capacidade de melhorar ao longo do tempo, característica que torna o modelo de indivíduo teórico de Mill dinâmico, foi mostrado que tal indivíduo apresenta, em sua natureza, faculdades mais elevadas que

${ }^{357}$ Mill, Utilitarismo, 1861, p. 196. 
derivam prazeres qualitativamente mais elevados, tais como, o prazer de ler um livro, ou o prazer de ouvir uma boa música, bem como a característica de poder agir por hábito. A característica mais patente da natureza do indivíduo é a própria busca da felicidade, ou em outros termos a maximização de prazer e minimização de dor, das quais derivam todo o valor das outras características da natureza humana, quando se pensa em ética ou ciência da moral para elaboração de regras da moralidade. Outra característica fundamental da natureza humana são as leis da mente, por elas passam todas as leis empíricas para a formação de leis científicas, é através delas que se constroem todas as leis científicas das ciências sociais.

Tendo em vista este modelo de indivíduo, sem dúvida, mais complexo do que o de Bentham, um indivíduo que, certamente olha para si porque busca a sua felicidade, mas que não pode ser reduzido ao auto-interesse, pois conforme os arranjos sociais evoluem, conforme as faculdades mais elevadas são despertadas, compreende que a busca da felicidade é algo que, muitas vezes, constitui em nela não pensar, em obter muitos e variados prazeres, em possuir tranqüilidade e emoção e não em uma vida de arroubos ou em uma vida egoísta.

"A felicidade de que falavam não significava uma vida de arroubo, mas momentos de êxtase numa existência constituída de poucas dores transitórias, muitos e variados prazeres, com um claro predomínio do ativo sobre o passivo (...). A deplorável educação, os deploráveis arranjos sociais são, atualmente, o único obstáculo real a que quase todos a realizem (...) "Os principais elementos constitutivos da vida satisfeita parecem ser dois (...): tranqüilidade e emoção (...) Depois do egoísmo, a principal causa que torna a vida insatisfatória é a falta de cultivo intelectual (...). [Mill, 1964, p. 196-197].

Desta forma, depreende-se que a moralidade do indivíduo teórico de Mill é mais complexa que a moralidade de Bentham, especialmente porque o indivíduo moral de Mill é mais complexo que o indivíduo moral de Bentham. Para que fosse formada a natureza do indivíduo moral de Mill, foram extraídas leis empíricas (verificações da experiência humana) sobre o comportamento humano, sendo estas, por indução, transformadas em generalizações universais, após serem transformadas em 
generalizações universais estas leis são aplicadas às leis da mente e então deduzidas e verificadas novamente, comparadas à experiência, corroboradas ou rejeitadas e assim formam-se as leis científicas e desta forma é possível compreender as leis gerais da natureza humana, bem como a principal dentre elas (porque é de onde as outras leis retiram seu valor), o fato de que os indivíduos sentem prazer e dor e buscam a felicidade.

Este é o fundamento das ações humanas e é também a finalidade da moral:

"se a felicidade for absolutamente impossivel para todos os seres humanos, sua realização não pode constituir a finalidade da moral (...)” [Mill, 1861, p. 195].

Está claro, portanto, que a moral tem por finalidade garantir a felicidade dos seres humanos, entretanto, qual é a definição de moralidade para Mill, no que ela constitui? Mill a define da seguinte forma:

Assim, é possível definir a moralidade como as regras e os preceitos de conduta humana, cuja observação permitiria que uma existência tal como a descrita fosse assegurada, na maior medida possível, a todos os homens ${ }^{358}$ [Mill, 1861, p. 194-195].

Portanto, conforme é tese deste trabalho, o utilitarismo de Mill apresenta mais espaço para a elaboração de regras morais do que o utilitarismo de Bentham precisamente porque a sociedade descrita por Mill é composta de indivíduos com uma natureza mais complexa e para que se entenda seu princípio de utilidade, ainda com a tese hedonista fundamental, muitos outros elementos precisam ser entendidos para a busca da felicidade que constitui a finalidade da moralidade. Dentre eles, encontra-se na própria definição de moral do utilitarismo de Mill o fato de que preceitos e regras de conduta humana são necessários para a observação de uma vida feliz, afinal esta é uma moralidade com mais espaço para regras morais relativamente à moralidade de Bentham.

\footnotetext{
${ }^{358}$ E Mill continua dizendo que esta existência feliz deveria ser assegurada a todos os seres sescientes de criação. "e não apenas a eles, mas também, na medida em que comporte a natureza das coisas, a todos os seres sencientes da criação”[Mill, 1861, p. 195].
} 
Conforme mencionado, os que não levam uma vida egoísta (fonte de uma vida infeliz) deixam atrás de si objetos de afeto pessoal e também afetos públicos, fazendo convergir seus interesses com os coletivos.

"Por outro lado, os que deixam atrás de si objetos de afeto pessoal e sobretudo os que também cultivam a solidariedade com os interesses coletivos da humanidade conservam, na beira da morte, um interesse pela vida tão intenso como o que mantinham no vigor da juventude e da saúde. Depois do egoísmo, a principal causa que torna a vida insatisfatória é a falta de cultivo intelectual” [Mill, 1861, p. 197].

Um espírito cultivado, Mill não se refere ao de um filósofo, mas ao de qualquer espírito que descobriu as fontes de conhecimento e que aprendeu a exercer suas faculdades mais elevadas, encontra recursos de interesse inesgotável em tudo o que rodeia. Nos objetos da natureza, nas obras de arte, nas criações da poesia, nos incidentes da história, nos caminhos da humanidade e em suas perspectivas para o futuro. Portanto, na tese hedonista do utilitarismo de Mill não há a necessidade de que o homem seja um egoísta $^{359}$, embora todos esses caminhos para a busca da felicidade que não o mero egoísmo, como a satisfação de faculdades mais elevadas ${ }^{360}$, afetos pessoais e públicos, decorrem do fato do indivíduo teórico de Mill possuir uma natureza mais complexa e derivam seu valor da felicidade ou prazer.

"Todo ser humano criado corretamente mostra que, em graus distintos, são possíveis afetos privados genuínos e um interesse sincero no bem público" [Mill, 1861, p. 198].

Para uma vida feliz e, portanto, para a formação do caráter dos indivíduos (da etologia individual), da etologia política ou do caráter nacional é necessário uma forte melhoria nos arranjos institucionais, propiciando educação e a prudência dos desejos. De acordo com Mill, a felicidade que os utilitaristas adotaram como padrão do que é certo

\footnotetext{
359“"Menos ainda existe uma necessidade inata de que todo homem deva ser um egoísta arraigado" [Mill, 1861, p. 198].

${ }^{360} \hat{E}$ importante notar que às faculdades mais elevadas estão associados prazeres qualitativamente superiores não intercambiáveis por prazeres de qualidade inferior, embora as necessidades básicas de um indivíduo devam ser satisfeitas para que as faculdades mais elevadas possam ser apreciadas devidamente.
} 
não é a felicidade do próprio agente, mas a felicidade de todos os envolvidos, pois o que conta na soma de felicidade conjunta é o prazer total ${ }^{361}$ de todos eles. Está claro que o agente deve buscar sua própria felicidade e deve, principalmente por sanção interna ${ }^{362}$, fazer convergir seus interesses com os interesses comuns, isto é louvável, entretanto não está obrigado a agir de forma que seus interesses sejam convergentes com os de outros ${ }^{363}$. Muito menos a moralidade utilitarista recomenda que um agente se obrigue a abrir mão de sua felicidade pessoal, em nome da felicidade dos outros.

"Honra aos que podem negar a si mesmos o gozo pessoal da vida, quando por tal renúncia contribuem dignamente para aumentar o montante de felicidade no mundo! Mas quem realiza esse sacrifício ou professa realizá-lo para outro propósito não merece mais a admiração do que o asceta instalado em sua coluna. Ele pode ser uma prova animadora do que os homens podem fazer, mas certamente não é um exemplo do que deveriam fazer" [Mill, 1861, p. 201].

Voltando à questão do que possibilita a formação do caráter nacional (etologia nacional ou individual - etologia individual) sabe-se que é a elaboração de arranjos institucionais adequados (que coloca os indivíduos em adequadas circunstâncias), conforme mencionado, bem como à prudência do desejo que é possível formar agentes com um caráter capaz de fazer coincidir seus interesses com os interesses da comunidade.

\begin{abstract}
"Num mundo em que há tantas coisas interessantes, tantas coisas agradáveis, e tanto para se corrigir e melhorar, cada um que possuir essa quantidade moderada de requisitos morais e intelectuais será capaz de levar uma existência invejável, por assim dizer; e, a menos que tal pessoa seja negada por meio de más leis ou pela sujeição à vontade de outros, a liberdade para usar as fontes da felicidade a seu alcance, não deixará de encontrar essa existência invejável se conseguir escapar aos males absolutos da vida - grandes fontes de sofrimento físico e mental, tais como a indigência,
\end{abstract}

\footnotetext{
${ }^{361}$ Mill, 1861, p. 202 "a felicidade que os utilitaristas adotaram como padrão do que é certo na conduta não é a do próprio agente, mas a de todos os envolvidos."

${ }^{362}$ A sanção ou constrangimento externo também existe.

${ }^{363}$ Vide Mill, 1861, p. 252.
} 
a doença e a perda rude, indigna ou prematura dos objetos do afeto. A principal ênfase do problema reside, portanto, na luta contra essas calamidades [...] frustrações relacionadas a circunstâncias mundanas se devem sobretudo quer à grave imprudência de desejos desregrados, quer a instituições sociais más ou imperfeitas” [Mill, 1861, p. 1999].

Desta forma, para fazer coincidir os interesses individuais com os coletivos e assim, maximizar a felicidade de todos os agentes envolvidos em uma ação o ideal de utilidade recomenda os seguintes meios: a) que as leis e os dispositivos sociais deveriam colocar (através do estímulo da livre vontade) o interesse de cada indivíduo em harmonia com o interesse do todo ${ }^{364}$, b) que a educação e a opinião as quais são tão poderosas sobre o caráter humano deveriam ser direcionadas para estabelecer, no espírito de cada indivíduo, uma associação indissolúvel entre sua própria felicidade e o bem do todo. Mais uma vez aqui as leis da mente entram em questão. Nada como, através da lei de associação fazer associar a felicidade individual com a coletiva em um indivíduo, para não nomear egoísta o indivíduo teórico de Mill. O autor tem argumentado em diversos livros, conforme vem-se articulando, o Sistema de Lógica, a Autobiografia e o Utilitarismo que diversos motivos de ação, como a simpatia entre indivíduos por exemplo, são ingredientes indispensáveis à constituição de uma sociedade coesa.

Os adversários do utilitarismo criticam esse modelo por ser demasiado elevado para a humanidade. Segundo afirmam, a pretensão de que as pessoas sempre ajam de acordo com o desejo de promover os interesses gerais da sociedade é uma exigência demasiado alta. Entretanto, isto é compreender mal o significado mesmo de um padrão de moralidade, e confundir a regra como motivo da ação. É assunto da ética informar a todos quais são os deveres dos agentes, nenhum sistema de ética exige, porém que o único motivo de todas as ações sejam o sentimento de agir para gerar o benefício alheio ${ }^{365}$. Ao contrário, a maioria das ações dos indivíduos é praticada por outros motivos e é corretamente praticada se a regra do dever não a condena.

\footnotetext{
${ }^{364}$ Mill, 1861, p. 203.

${ }^{365}$ Ibid. p. 204.
} 
“(...) não há nada na teoria utilitarista incoerente com o fato de que outras coisas nos interessam nas pessoas além da justiça ou injustiça de suas ações."

Mill ao efetuar a defesa do utilitarismo, ressalta que não há nada na teoria utilitarista incoerente com o fato de que outras coisas interessam às pessoas além da justiça ou injustiça de suas ações. Os utilitaristas estão perfeitamente cientes de que existem, além da justiça ou injustiça das ações para com outros, outros bens e outras qualidades desejáveis e estão inteiramente dispostos a atribuir a todos eles seu pleno valor.

Tendo em vista que a justiça e a injustiça das ações não constituem as únicas preocupações dos indivíduos, há também espaço para indicações para uma boa vida na moralidade do utilitarismo de Mill, conforme se tem mostrado ${ }^{366}$. Tudo isto compõe a arte da moralidade e satisfaz esta natureza mais complexa descrita por ele ${ }^{367}$. Há que se lembrar, contudo, que na origem destas regras morais estão os ditames do prazer e fuga ou ausência da dor, ainda que o hábito, qualidade, também da natureza humana, possibilite o descolamento da busca pelo prazer no momento das ações.

"A vontade, fenômeno ativo, é diferente do desejo, estado de sensibilidade passiva; e embora em sua origem seja um rebento do desejo, pode com o tempo deitar raízes e se desapegar da cepa materna, tanto é assim que, no caso de um propósito buscado por hábito, em vez de querer uma coisa porque a desejamos, com freqüencia a desejamos apenas porque a queremos"(...) Às vezes isso é feito de maneira inconsciente, já que a consciência vem só depois da ação; outras vezes se trata de um ato de vontade consciente, mas de uma vontade que se tornou habitual e se põe em ação pela força do hábito (...)”. [Mill, 1861, p. 240]

Desta forma, não apenas verifica-se que Mill descreve ditames para melhor moldar o caráter dos indivíduos (como melhores arranjos institucionais para fazer convergir muitos dos interesses individuais com os coletivos, bem como indica a melhoria da educação como uma saída para a melhoria do gosto dos indivíduos, ativação

\footnotetext{
${ }^{366}$ Mill, 1861, p. 206.

${ }^{367}$ Pode-se dizer que Mill concorda com Bentham no fato de que ele é um consequencialista, uma vez que diz que no longo prazo a melhor prova do bom caráter de um agente são as boas ações. [Mill, 1861, p. 207]
} 
das faculdades mais elevadas, cultivo por livros, pintura, boa música, etc), como verifica na prática que os homens adquirem crenças firmes e nelas se baseiam quanto ao efeito de algumas ações sobre suas felicidades. Estas são as chamadas regras da moralidade costumeira, são preceitos como (não roube, não mate, deseje desenvolver o intelecto, que se leia, que se aprecie a arte, que se seja corajoso, etc) que constituem as regras da ética para os homens comuns, bem como para o filósofo até que, com o tempo, conforme a sociedade progrida (Mill sempre pensa em progresso intelectual quando a palavra é progresso $^{368}$, pois dele tudo dependeria) por meio do princípio da utilidade, consiga-se outras regras morais melhores.

\begin{abstract}
“(...); e as crenças assim transmitidas constituem as regras da moralidade para multidão, bem como para o filósofo, até que consiga encontrar outras melhores (...)". (...) Os corolários do princípio de utilidade, assim como os preceitos de todas as artes práticas, são suscetíveis de um avanço indefinido (...)”.
\end{abstract}

Poder-se-ia indagar se este indivíduo não é como o de Bentham que a cada ação efetua um cálculo para revisar os costumes ou a moralidade costumeira e acaba por transformar-se em um robô das ações, um homem frio, detentor de uma razão calculadora. O indivíduo teórico de Mill é, de outra parte, composto de uma natureza mais complexa, e por possuir estes novos elementos é possível que se capture melhor as circunstâncias em que ele age, ou, em outras palavras é possível explicar melhor a importância da moralidade costumeira, das regras morais. O indivíduo do utilitarismo de Mill, por possuir esta natureza mais complexa, (além de concordar com a tese hedonista, apresenta elementos como o agir por hábito, como possuir faculdades mais elevadas que se satisfazem com prazeres mais elevados, como a capacidade de se transformar ao longo do tempo e ainda possuir as leis mentais que permitem formular novas leis científicas sociais) torna possível que a moralidade possua mais espaço para regras morais. No fundamento da moralidade está a felicidade como finalidade, ou fundamento, ou seja, o princípio da utilidade que ressalta que é correto buscar o prazer e errôneo buscar a dor e que o prazer ou felicidade possui valor em si, mas o fato do indivíduo teórico de Mill

\footnotetext{
${ }^{368}$ Conforme ressaltado no capítulo terceiro, progresso significa a sucessão da sociedade que pode ser para pior, embora Mill pense que a sociedade tenha uma tendência à melhora.
} 
possuir uma natureza mais completa relativamente à de Bentham faz com que na própria formulação do princípio de utilidade conste o fato de que para dar uma idéia clara do padrão de moralidade estabelecido pela teoria, muito mais precisaria ser dito. Abaixo cita-se a formulação do princípio de utilidade de Mill, o famoso parágrafo 2.2.

"O credo que aceita a utilidade ou o princípio da maior felicidade como fundação da moral sustenta que as ações são corretas na medida em que tendem a promover a felicidade e erradas conforme tendam a produzir o contrário da felicidade. Por felicidade se entende prazer e a ausência de dor, por infelicidade, dor e a privação do prazer. Para dar uma clara idéia do padrão moral estabelecido pela teoria, é preciso dizer muito mais; trata-se de saber, em particular, o que está incluído nas idéias de dor e prazer e em que medida esse debate é uma questão aberta. Mas essas explicações suplementares não afetam a teoria de vida sobre a qual se funda a teoria da moralidade, a saber, que o prazer e a imunidade à dor são as únicas coisas desejáveis como fins, e que todas as coisas desejáveis (as quais são tão numerosas no esquema utilitarista como em qualquer outro) são desejáveis quer pelo prazer inerente a elas mesmas, quer como meios ${ }^{369}$ para alcançar o prazer e evitar a dor" [Mill, 1861, p. 187].

Conforme citado, o princípio de utilidade de Mill pode incluir explicações adicionais a respeito do padrão moral estabelecido, embora isto não afete o fato do autor continuar a ser um utilitarista, em outros termos, sustentar que é correto que as pessoas persigam sua felicidade e errôneo que as pessoas persigam sua dor. Este princípio de utilidade mais complexo, ou preceito mais complexo, sustentado nesta tese, advém de uma natureza humana mais complexa do indivíduo teórico de Mill. Uma pergunta, então, poderia ser colocada: como as outras características do indivíduo teórico de Mill articulam-se para derivar as regras morais. A tese hedonista, conforme tem-se mostrado, dá origem ao tema central do princípio de utilidade que ressalta que os indivíduos devem buscar prazer e devem fugir da dor, o fato dos indivíduos serem dotados de faculdades

\footnotetext{
${ }^{369}$ Em outros parágrafos Mill ressalta que os indivíduos podem desejar outros fins que não a felicidade e estes fins seriam como que partes da felicidade e não meios. Há também o argumento de que os indivíduos poderiam agir inconscientemente e, portanto, estarem visando algum fim sem estarem pensando momentaneamente na felicidade.
} 
mais elevadas, quando ativadas, permite que os indivíduos possam experimentar prazeres de qualidade mais elevada, prazeres propriamente humanos. Além disso, uma vez que os indivíduos experimentam tais prazeres eles não trocam por prazeres menos elevados ${ }^{370}$, no sentido de que os homens não trocam vidas propriamente humanas por vidas animais. Esta característica permite que os indivíduos tomem gosto por apreciar o desenvolvimento intelectual, pela apreciação da arte, pelo desenvolvimento de simpatia pelos outros, pelo desenvolvimento de sentimentos morais (gostar de praticar o bem ou gerar prazer a outros), por fazer convergir seus interesses com os da sociedade, etc. Do agir por hábito, surge a possibilidade do agente não precisar efetuar um balanço em todos os momentos da ação, faz com que o indivíduo possa agir de acordo com regras morais que foram frutos de cálculos ou acordos passados, em outras palavras o agente pode agir de acordo com regras da moralidade costumeira (como não mate, não roube, desenvolvase intelectualmente, aprecie a arte, seja corajoso, etc). Da capacidade de poder transformar-se ao longo do tempo surge a característica dinâmica do indivíduo, a capacidade que o indivíduo tem de desenvolver-se, principalmente, intelectualmente, conforme o tempo passa.

Todas as conseqüências deduzidas da natureza humana do indivíduo teórico de Mill (uma ciência) convertem-se em preceitos, conforme vem-se defendendo nesta tese. O preceito primeiro e fundamento da teoria da utilidade é o princípio da utilidade, mas todas estas outras características da natureza humana do indivíduo teórico de Mill permitem que o indivíduo converta as conseqüências dessa ciência da natureza humana, com o princípio da utilidade, mas para além dele em outros preceitos morais: que não roube, que não mate, que seja corajoso, que não minta, que um indivíduo se desenvolva intelectualmente, que aprecie a arte, que simpatize com os outros, que se interesse pelos assuntos públicos, que faça convergir seus interesses com os dos outros, entre outras normas morais que podem ser convertidas como conseqüência das características científicas da natureza humana do indivíduo teórico de Mill. Desta forma, tem-se a possibilidade da formação de uma moral positiva, com a efetuação de regras morais que não serão questionadas a cada ação, mas de tempos em tempos, conforme o indivíduo progrida, diferentemente da moral de Bentham; uma moral negativa, pois o indivíduo era

\footnotetext{
${ }^{370}$ Isto é claro considerando que suas necessidades básicas foram atendidas.
} 
dotado de uma racionalidade calculadora que fazia cálculos entre prazer e dor a toda ação, questionando as regras do costume, conforme cálculos. Vale lembrar que nenhuma das regras do indivíduo teórico de Mill viola a tese hedonista ou o princípio de utilidade de busca da felicidade por parte do agente, uma vez que todas visam o fim último coletivo e individual que é a busca da felicidade.

O hábito, conforme mencionado, permite que os indivíduos não efetuem um balanço entre prazer e dor a cada instante da ação, permite que os indivíduos possam agir conforme decisões passadas, conforme os costumes (ou princípios secundários da moral), empresta constâncias às regras da moralidade, permitindo que os indivíduos deixem de efetuar balanços entre prazer e dor a cada ação.

Corroborando o que foi dito, afirma Mill:

"Pois a moralidade gerada pelo costume, a que se consagram a educação e a opinião, é a única que se apresenta ao espírito com o sentimento de ser em si mesma obrigatória" [1861, p. 217].

Os corolários da ética, os princípios secundários ou preceitos da moralidade parecem ter mais força compulsória do que o teorema original. Entretanto, deve-se ter em mente que estes princípios secundários de ação ou regras da moral foram formados, porque na origem de uma determinada ação o indivíduo considerava prazeroso efetuá-la. Porém, uma vez que a ação torna-se habitual, os agentes não mais pensam nas ações que efetuam quando agem. Isto é o mais comum do indivíduo teórico de Mill e não que ele seja uma "máquina de efetuar cálculos" a cada ação, como parece ser o indivíduo no utilitarismo de Bentham.

Portanto, fica provado que há espaço, no utilitarismo de Mill, para a elaboração de regras ou princípios secundários como: não matarás, não roubarás, que a arte seja apreciada, que se cultive o intelecto, que se cultive os assuntos públicos, que não se minta etc. 
As regras morais dividem-se entre as mais obrigatórias que se relacionam a questões de justiça e, portanto, geram direitos e deveres ${ }^{371}$ e as que dizem respeito a condução da vida de uma pessoa (como que se aprimore o intelecto, que se estude, que se aprecie a arte, que se faça bem ao próximo etc). O dever é algo que se pode ser exigido de uma pessoa, tal como o pagamento de uma dívida. Portanto, as regras morais que podem ser designadas como obrigações morais não se distinguem da justiça, pois geram direitos e deveres. As regras morais que geram direitos e que, portanto, estão associadas às condições essenciais do bem-estar humano, em outras palavras, as regras morais que são mais rigorosamente obrigatórias do que outras regras de conduta da vida são as regras que proíbem os seres humanos a prejudicarem uns aos outros (quando ocorre uma interferência injusta na liberdade) e aqui se insere as duas máximas essenciais de ação do livro A Liberdade, ou princípios secundários de ação ancorados no princípio de utilidade: a) "o indivíduo não é responsável perante a sociedade por suas ações, enquanto estas não afetarem os interesses de nenhum outro além dele mesmo. Conselhos, instrução, persuasão e isolamento, caso julguem necessário recorrer a este último meio para seu próprio bem, são as únicas medidas pelas quais a sociedade pode com justiça exprimir seu desagrado" [Mill, 1859, p. 143]. Esta máxima demonstra que regras morais ou preceitos podem ser gerados quando não há interações entre indivíduos, como que se aprecie a arte, que se aprimore se intelecto, etc e pode haver uma certa sanção moral (como o Isolamento), contudo, não são regras morais que geram direitos. As regras morais que geram direitos dizem respeito à segunda máxima do livro A Liberdade de Mill, a saber: b) Segundo, o indivíduo é responsável pelas ações prejudiciais aos interesses de outros, sujeitando-se então quer à punição social, quer à legal, se a sociedade julgar que uma ou outra seja necessária à sua proteção [Mill, 1859, p. 144]. Então regras morais como que não se deve privar alguém de sua liberdade (esta regra pode, inclusive, transformar-se em uma norma legal, aquilo que decidirá se a norma será legal ou moral, em última instância será estes princípios ou máximas secundárias da liberdade, caso a norma não possa ser mantida sob a censura ou punição da moralidade,

\footnotetext{
${ }^{371}$ Além disso o sentimento de justiça compreende dois elementos essenciais, a saber: o desejo de punir a pessoa que causa o dano e o conhecimento ou a crença de que há um ou mais indivíduos determinados a quem foi causado o dano (derivados do impulso de autodefesa e do desejo de simpatia). Mill, 1861, p. 256.
} 
por se tratar de um mal de grande risco para a sociedade um apelo ao primeiro princípio deve ser feito, ou um cálculo entre custo benefício, conforme enuncia Mill).

"Ficaríamos gratos por ver a conduta justa imposta e a injustiça reprimida, até os mais ínfimos detalhes, se, com razão, não receássemos confiar aos magistrados um poder tão ilimitado sobre os indivíduos. Quando pensamos que uma pessoa está, com justiça, obrigada a praticar um ato, dizemos, em linguagem corrente, que ela devia ser compelida a praticá-lo. Seria agradável a nós ver a obrigação imposta por alguém que tivesse poder para isso. Se vemos que essa compulsão exercida pela lei seria inconveniente, lamentamos a impossibilidade, consideramos como um mal a impunidade conferida à injustiça, e nos empenhamos em reparar esse mal, conferindo uma expressão enérgica a nossa desaprovação do público que será infligida ao culpado. Assim, é sempre a idéia de um constrangimento legal que está na origem da noção de justiça, ainda que esta sofra diversas transformações até tomar a forma acabada que apresenta num estado avançado da sociedade”. [Mill,1861, p.152].

Além disso, não há diferença de natureza entre as regras morais (que geram direitos) e as regras legais ou regras de justiça, segundo enuncia Mill [1861, p. 253]: [...] nada nos permite distinguir a obrigação de justiça da obrigação moral em geral, tanto para Bentham, como para Mill, o que as distingue, no caso de Bentham é um cálculo de custo benefício, o quanto uma regra legal irá custar para a sociedade, dado que toda punição é um mal, no caso de Mil o princípio de utilidade também está na base da construção dos princípios secundários da liberdade que ditarão se uma regra ficará sob o escopo moral ou legal, contudo é o fato do indivíduo poder ser mais livre que explicará a preferência por uma regra de conduta (no caso de um indivíduo gerar mal a outro) ficar no âmbito moral ou legal. Isto porque, entende-se que o governo tem o poder de tolher a liberdade dos indivíduos.

Assim, todas as regras morais que geram direitos constituem deveres a serem cumpridos por aqueles que geraram um direito e estas regras são todas relacionadas à segunda máxima da liberdade que enuncia que um indivíduo é responsável perante a sociedade por gerar mal a outrem, caso viole o dever que deve cumprir. Regras 
morais desse tipo são as seguintes: aquele que empenha a sua palavra, não deve mentir (essa é a regra moral), pois de acordo com a segunda máxima da liberdade, uma vez dada a palavra, mentir ocasiona um mal a um terceiro que tem o direito a receber a verdade. Além disso, as pessoas têm o direito a sua liberdade (conforme enunciou-se acima), a liberdade representa um direito de todos os homens e um dever que seja garantida (do Estado, pois só este tem o poder coercitivo suficiente para mantê-la), então, cria-se a regra legal de que o Estado deve garantir a segurança dos indivíduos. Outras regras morais que geram direitos pelo fato das ações poderem ocasionar mal a indivíduos dizem respeito a tratar alguém conforme o mérito, não privar ninguém do que pertence (este é o tipo de regra que deve ficar sob a jurisdição do Estado, pois só ele pode garantir os pertences de alguém). A imparcialidade, especialmente em um julgamento, é um bom exemplo de regra moral que gera um direito moral, pois seu rompimento gera dor, dano. Manter expectativas geradas é outra regra moral que gera direito, pois seu rompimento também ocasiona dor, mas sem dúvida deve ser mantida, apenas, sob o escopo da moralidade, podendo obter repressão informal social, uma vez que formular uma lei formal para que as pessoas cumpram as expectativas geradas ${ }^{372}$ ocasionaria uma demasiada intromissão na liberdade dos indivíduos.

As outras regras morais que não dizem respeito a interações entre indivíduos que podem ocasionar um mal, que podem gerar um bem entre eles (regras de beneficência) ou que constituem regras que não envolvem interações entre indivíduos, mas apenas e tão somente são regras que o indivíduo segue para melhor conduzir sua vida rumo à felicidade. São regras morais que não geram um dever ${ }^{373}$ ou um direito, mas também são necessárias, pois sempre há bons motivos para que se faça o bem, seja pela força do hábito, seja por um apelo ao primeiro princípio (para que se aumente o somatório do prazer no cômputo geral) e há excelentes razões para que os agentes se coloquem regras morais para sua conduta de vida rumo à felicidade, embora as regras obrigatórias $^{374}$ (que geram direitos morais) sejam aquelas que podem ocasionar um mal. Conforme ressalta Mill [1861, p.270]:

\footnotetext{
${ }^{372}$ Mill, 1861, p. 271.

${ }^{373}$ West, 2007, p. 118.

${ }^{374}$ Skorupski, 2007, p.36
} 
"o interesse que têm em inculcar em cada um o dever de beneficência positiva é incontestável, mas num grau muito menor, pois é possível que não necessitemos dos benefícios de outros. Mas sempre necessitamos que não nos causem prejuizo. Assim, as regras morais que protegem cada indivíduo dos prejuízos que os outros possam causar-lhe, seja impedindo sua liberdade de procurar o seu próprio bem, são as que the são mais caras. [...] Ora, são essas regras morais que fundamentam a obrigações de justiça."

Não obstante, as outras regras que derivam da natureza humana mais complexa do indivíduo teórico de Mill, como fazer convergir o interesse próprio com o interesse coletivo (que está intimamente relacionada à capacidade que o indivíduo tem de transformar-se ao longo do tempo), como cultivar a arte, o intelecto e obter prazeres de qualidade superior (que está totalmente relacionado ao fato do indivíduo possuir faculdades mais elevadas), poder lançar-se no mundo possuindo estas regras como resultado de decisões passadas e não precisar a todo instante efetuar cálculos entre prazer e dor, como realiza o indivíduo teórico de Bentham são também parte da moralidade e totalmente importantes à busca da felicidade. Na passagem seguinte Mill afirma que a moralidade é maior do que os casos de justiça que geram uma obrigação moral (que são os casos que são passíveis de gerar dor aos outros) em [1861, p. 255]:

"Onde quer que haja um direito, há um caso de justiça e não de beneficência; e quem não situar a distinção entre justiça e moralidade em geral onde acabamos de situar acabará por não fazer distinção alguma entre elas e reduzirá toda a moralidade à justiça”.

Desta forma, independente do fato das regras da moralidade, do indivíduo teórico de Mill, serem divididas em regras morais que geram direitos e, portanto, pertencerem às regras de justiça (serem obrigatórias à constituição do caráter), ou constituírem regras da moralidade que não geram direitos morais e, portanto, apenas apontarem como o indivíduo melhor se conduz no mundo, ou compõe melhor a sua felicidade ou quando há interações entre indivíduos e há geração de benefícios aos indivíduos, as regras tratam de regras de beneficência como fazer convergir os interesses 
individuais com os coletivos, o que é importante ter em vista é que o indivíduo teórico de Mill, devido a sua natureza humana age, portanto, se lança no campo prático dotado dos princípios secundários ou regras morais, devido à natureza mais complexa que possui relativamente ao indivíduo do Bentham.

Em outras palavras, há uma moral positiva para Mill, mais ampla, relativamente à moral de Bentham, com regras estabelecidas, por decisões passadas (moralidade dos costumes), ainda que embasadas em um cálculo (no primeiro princípio), possibilitada pela natureza de seu indivíduo (composta pelas leis da mente, tese hedonista, hábito, faculdades mais elevadas e capacidade de se transformar ao longo do tempo) que não são contestadas, por um cálculo entre prazer e dor, a cada ação, como para o indivíduo teórico de Bentham. Ao contrário, estas regras mudam de períodos de tempos para períodos de tempos (períodos críticos como argumentou-se no capítulo terceiro). Alguém poderia indagar se este indivíduo não seria menos livre pelo fato de haver mais espaço para a elaboração de regras de conduta, no utilitarismo de Mill? A resposta é negativa, pois Mill identifica a falta de liberdade com a interferência nas liberdades individuais, principalmente por parte do governo. Este só deve intervir, nos casos em que há a iminência de poder haver a geração de mal por indivíduos uns aos outros, especialmente, no caso da segurança (como nos casos de risco de se retirar a liberdade de alguém, a propriedade, etc) e em alguns outros casos especiais conforme se tratará no próximo capítulo. O indivíduo não é responsável perante a sociedade no que diz respeito às outras regras morais que não geram direitos, conforme enuncia a primeira máxima de liberdade. O máximo que a sociedade pode fazer no que diz respeito a estas regras é dar conselhos, instruir, isolar o indivíduo, mas não cobrá-lo como se cobra o pagamento de uma dívida. Além disso, a elaboração de regras morais não significa a diminuição da liberdade dos indivíduos, uma vez que esses indivíduos necessitam de regras no campo prático do agir, a questão toda reside na maneira como este indivíduo irá agir, se através de um cálculo a todo instante, ou se através do hábito e outros elementos que a natureza humana do indivíduo do Mill permite.

Tendo esses elementos claros, parte-se para explicar situações ordinárias da vida como: deve um indivíduo descumprir um compromisso que marcou com um amigo, porque foi chamado a uma reunião de última hora por seu chefe? O que fazer? A resposta 
parece ser simples: quando os princípios secundários entram em conflito, o primeiro princípio ou o princípio da utilidade, um cálculo entre prazer e dor ou felicidade deve vir à tona.

Desta questão surge a famosa controversa dentro do utilitarismo:

É Mill um Act Utilitarianian ou um Rule Utilitarian? É Mill um utilitarista de ato ou um utilitarista de regra?

2 O Utilitarismo de Regra versus o Utilitarismo de Ato $^{375}$

O utilitarismo de ato é o que os filósofos chamam de teoria moral direta, uma vez que o princípio de maximização aplica-se aos atos, considerando que a ação correta maximiza felicidade, necessariamente.

Entretanto, alguns escritores têm interpretado o utilitarismo a partir de outra versão denominada utilitarismo de regra ${ }^{376}$. O utilitarismo de regra também foca sua teoria em ações, mas a retidão ou erro das ações não depende do fato de se elas maximizam felicidade diretamente, mas se elas seguem certas regras, i.e. aquelas que maximizam felicidade e que foram aceitas pela maioria das pessoas. De acordo com o utilitarismo de regra, uma ação particular é justificada como sendo correta por mostrar que está de acordo com alguma regra moral. É mostrada como incorreta por mostrar que transgride uma regra moral. Uma regra moral é denominada correta pelo reconhecimento que aquela regra promove o fim último que é guiar para o maior grau de felicidade permitido por todos os tipos de contratos e arranjos entre as pessoas.

Dando um exemplo usando ambos os conceitos: considere-se a mentira. Se um indivíduo faz uma promessa para outrem e uma situação surge de tal forma que quebrar a promessa maximizará utilidade, o utilitarismo de ato requer que o agente quebre a promessa. Enquanto, levando em consideração o utilitarismo de regras, seria requerido do agente que ele mantivesse as promessas, se as regras amplamente aceitas, promovem a felicidade para o maior número possível. No utilitarismo de regra seriam

${ }^{375}$ The Rule Utilitarianism vs. Act Utilitarianism

${ }^{376}$ Urmson, 1953. 
permitidos todos os tipos de contratos e arranjos sociais os quais fariam as pessoas confiarem umas nas outras. Desta forma, desde que fosse proibido por uma regra moralmente justificável (dentro do utilitarismo), o quebrar de uma promessa, no caso particular do utilitarismo de regra isto não seria aceitável.

A questão que surge desta breve discussão sobre utilitarismo de ato e utilitarismo de regra é: é Mill um utilitarista de ato ou um utilitarista de regra ou nenhum dos dois?

De acordo com Roger Crisp, Mill é o tipo de filósofo que é membro de uma escola indutiva o que significa que ele "faz parte de um grupo de filósofos que embasam suas filosofias morais na observação e experiência" ${ }^{377}$ [Crisp, 1996], em outras palavras, deve-se assumir que a moralidade de uma ação envolve aplicar regras gerais a casos particulares. Entretanto, argumenta Crisp, a regra geral é o princípio de utilidade e, portanto, um princípio ligado mais ao utilitarismo de ato. Crisp pensa que Mill não é um utilitarista de regra e este trabalho concorda com Crisp, neste sentido. Contudo, é impossível não conceder um certo peso ao utilitarismo de regra, especialmente, quando se considera o livro de Mill denominado Utilitarismo e mesmo quando se analisa o livro VI do Sistema de Lógica de Mill. Então, afirma-se, neste trabalho, que Mill é um utilitarista de ato mais complexo (devido à natureza mais complexa de seu indivíduo que permite derivar uma moralidade positiva) ou um filósofo que apresenta muitos níveis de utilitarismo, assim como Crisp o nomeia, porque ele possui muitos níveis de significado de utilitarismo.

Realizando um sumário do que foi dito, é possível concluir que o utilitarismo de ato decide sobre a retidão ou erro de uma ação em última instância, mas existem muitos casos morais, nos quais não é necessário apelar para o utilitarismo de ato, porque existe um conjunto de ações estabelecidas derivadas dos costumes, tradição, (cuja garantia de que o indivíduo as respeitará é o agir por hábito) e de acordos implícitos, a partir de ações passadas, na sociedade que guiam muitas ações morais (e de acordo com Mill a moralidade costumeira, inclusive, se apresenta aos sentimentos como mais

\footnotetext{
${ }^{377}$ De fato a afirmação de Crisp está de acordo com as afirmações deste trabalho, pois como observou-se, é por indução que se extraem as mais altas generalizações na lógica de Mill.
} 
compreensível do que os primeiros princípios) ${ }^{378}$. Entretanto, como Crisp ressalta, são considerados, no trabalho de Mill, alguns níveis de pensamento moral.

Segundo Crisp, Mill pensa que as ações corretas são aquelas que maximizam prazer. É importante notar que o utilitarismo de ato deve ser entendido apenas como uma teoria sobre o critério da ação correta. Crisp ressalta que nada segue do fato de como as pessoas deveriam pensar ou sobre a forma como deveriam agir em suas vidas cotidianas. Este fato, entretanto, não interfere no fato de que um utilitarista de regra deveria, sempre, apontar para como conscientemente, tentar maximizar o bem-estar em qualquer oportunidade possível. Isto é o que Crisp chama de nível simples do utilitarismo de ato, uma vez que aquele que formula a teoria está recomendando que os agentes morais pensem apenas neste nível de utilitarismo, permitindo que seus pensamento sejam dominados, constantemente, apenas pelo utilitarismo de ato.

Para tentar maximizar bem-estar por meio da ação a cada oportunidade possível (aqui pode-se pensar que seria o indivíduo Benthamita que faria um cálculo ou balanço entre prazer e dor a cada oportunidade ou ação) ocorre o que deve-se denominar nível simples de utilitarismo de ato, uma vez que o teórico recomenda que o pensamento seja dominado, constantemente, pelo utilitarismo de ato. As ações de todos seriam adotadas com nenhum outro objetivo além de maximizar bem-estar, segundo Crisp. O utilitarismo como um procedimento de decisão de nível simples requer tanto que o agente seja inteiramente imparcial entre as pessoas, pois se trata da maximização de utilidade da maioria e não apenas individual (ou entre suas utilidades) ou que o indivíduo seja educado ao ponto em que a teoria possa ser racionalmente aplicada.

Crisp $^{379}$ duvida se tal sociedade é mesmo uma possibilidade para os seres humanos, porque os requisitos de imparcialidade e racionalidade parecem ser muito exigentes para com os sujeitos. As crianças, por exemplo, são criadas em culturas e tradições e todas estas crenças, culturas e tradições incorporam-se nos indivíduos parcialmente. Os pais, professores e outros na sociedade estabelecem relações especiais com as crianças, fazendo o possível para torná-las racionais.

\footnotetext{
${ }^{378}$ Op.cit. Mill, 1861, p. 217.

${ }^{379}$ Crisp, 1996.
} 
Um nível simples de utilitarismo do ato deve aceitar este ponto e argumentar que um sujeito deveria ser o máximo possível imparcial dentro de constrangimentos psicológicos de parcialidades que surgiram a partir de sua educação. O nível simples do teórico que formula o utilitarismo de ato deve sugerir que tudo o que agentes com pensamento moral devem fazer é ser um act utilitarian ou um utilitarista de ato. Contudo, o utilitarismo de ato perde o ponto de que o desenvolvimento das parcialidades (ou crenças, moralidade costumeira) é ela mesma, moralizante ${ }^{380}$, desenvolvem princípios secundários. Além disso, é tese deste trabalho que a natureza mais complexa do indivíduo teórico de Mill abre espaço para a formulação de uma moralidade positiva (com regras morais para além do princípio de utilidade) e, portanto, para que o indivíduo teórico de Mill não seja apenas um utilitarista de ato, ou aja de acordo com um balanço entre prazer e dor.

Quando se pergunta porque teóricos do pensamento relacionaram ao nível simples do utilitarismo de ato a constante tentativa de maximização de utilidade, eles respondem que este método de construir o pensamento moral é o que mais conduz ao bem-estar geral. Entretanto, parece ser extremamente improvável que pessoas, em uma sociedade, gastem tempo calculando os valores do bem-estar do vários cursos de ação abertos a eles a qualquer momento, os indivíduos nunca parariam de calcular, transformar-se-iam em "calculadores frios" e nada seria atingido a tempo. É tese deste trabalho que Mill reconhece que não há necessidade para pensar que como uma teoria moral haja necessidade da adoção do utilitarismo de ato como um procedimento de nível simples. Além disso, Mill afirma que a moralidade costumeira que estabelece os princípios da moral na qual a maioria dos agentes é educada para aceitar e rejeitar regras como, por exemplo: não praticar assassinato ou roubo surgiu devido à influência tácita de um padrão cultural reconhecido ${ }^{381}$, devido à natureza mais complexa que o agente teórico de Mill possui.

Desta forma, as regras da moralidade dos costumes poupam tempo e são derivadas de uma natureza humana mais complexa, de um indivíduo mais complexo,

\footnotetext{
${ }^{380}$ Esta é a questão do parágrafo 3.1 do livro Utilitarismo em que Mill descreve que as regras da moralidade costumeira parecem muitas vezes de mais fácil aceitação do que os primeiros princípios. Tal afirmação de Mill corrobora a tese fundamental deste trabalho, pois há, no utilitarismo de Mill, mais espaço para a formulação de regras morais, quando comparado ao utilitarismo de Bentham.

${ }^{381}$ Vide Mill em Utilitarismo, 1861, p. 217.
} 
quando comparado ao indivíduo teórico de Bentham que age no nível simples do utilitarismo de ato. As regras da moralidade dos costumes são baseadas na experiência da humanidade de tempos passados, entretanto, podem ter sua justificativa no primeiro princípio. Urmson, entretanto, sugere que as regras da moralidade costumeira desempenham o papel mais fundamental, na teoria de Mill, como critério para avaliar as ações morais. A partir destes dois contrapontos a questão que surge é a seguinte: Mill não é um utilitarista de ato de nível simples (como Bentham o é), conforme tentou-se argumentar, ao mesmo tempo, admite as regras da moralidade costumeira em seu pensamento moral e mesmo que o Estado, a partir de melhoramentos institucionais fomente novas regras morais compatíveis com o progresso individual e coletivo (principalmente intelectual). Então, está Mill ressaltando que o utilitarismo embora seja uma teoria sobre a retidão das ações nunca deveria desempenhar um papel na moralidade dos agentes? Está ele oferecendo, em outras palavras, uma versão modesta do utilitarismo de ato, de acordo com a qual existem boas razões utilitárias para nunca consultar a teoria do utilitarismo de ato nos procedimentos de utilidade? De fato Mill não é nem um utilitarista de nível simples nem um utilitarista modesto, ele pode ser chamado de um utilitarista de multi-nível de um tipo particular, nas palavras de Crisp. Às vezes o utilitarismo de Mill recomenda que se deve seguir a moralidade dos costumes ou princípios secundários (como não mate, não roube, seja corajoso, pratique o bem, seja temperante, etc) porque a maioria dos humanos foi criada sob essas regras e concede um assentimento a elas mais imediato do que aos primeiros princípios. Entretanto, uma reflexão sobre a natureza da moralidade costumeira mostra, incidentalmente, porque pensar estas regras pode levar ao erro. Poder-se-ia imaginar um utilitarista de ato que tomou a moralidade costumeira como um conjunto de regras a se pensar tais como a seguinte: deveria eu matar meu amigo? Bem, é certo que a moralidade costumeira contém uma regra que ordena que ninguém deve matar porque matar mostrou causar infelicidade (não maximiza felicidade). Parte da função da moralidade costumeira é moldar o que se pensa, o que se sente e quais as opções de ações são tomadas a sério. A moralidade costumeira é inculcada a fundo nos sujeitos (o que inclui um pensamento passado e um apelo também passado ao prazer), mas uma vez que se torna um hábito é transformada 
quase em uma parte natural do caráter dos agentes, como sugerido pela seguinte passagem de Mill:

\begin{abstract}
"É associando a ação reta com o prazer, ou a ação nociva com a dor, ou trazendo à tona, enfatizando, introduzindo em sua experiência o prazer que naturalmente se segue da primeira e a dor resultante da segunda, que se torna possível provocar a vontade de ser virtuoso que, uma vez afirmada, age independentemente de toda idéia de prazer ou de dor. A vontade é filha do desejo, e abandona a tutela de seus pais apenas para se alojar ao hábito [...]” [Mill, 1861, p. 240]
\end{abstract}

Desta forma, os agentes nunca deveriam efetuar a pergunta se deveriam ou não matar outros, na maioria das circunstâncias ${ }^{382}$. Em outras palavras, Mill sugere que os sujeitos ${ }^{383}$ devem guiar-se, na maior parte dos casos, com as regras da moralidade costumeira, ou os princípios secundários, ou os corolários do princípio da utilidade, pois sabe-se que em sua origem, estas ações só tornaram-se costumes, porque tornavam os homens felizes. Neste sentido, quando Mill ressalta que os agentes dão assentimento mais facilmente para a moralidade dos costumes do que para os primeiros princípios, pode-se dizer esta afirmação é derivada da mais complexa natureza humana do indivíduo teórico de Mill, pois uma das conseqüências dos agentes sentirem prazeres de natureza mais elevada é dar possibilidade aos sentimentos morais também operarem para aquiescerem as regras do costume, tornando a opção pelas regras da moralidade a única plausível e consistente com o indivíduo moral que ele traça. Além disso, conforme mencionado anteriormente, outra característica da natureza mais complexa do indivíduo teórico de Mill refere-se ao fato de que ele não realiza cálculos a todo instante, mas pode agir por hábito, por regras morais decidas no passado e que constam no presente, embora a tese hedonista de que estas regras derivem seu valor do prazer seja respeitada.

Entretanto, quando princípios secundários da moralidade costumeira entram em conflito, o utilitarismo de ato da benevolência imparcial deveria ser chamado para

\footnotetext{
${ }^{382}$ Para Aristóteles o excesso de deliberação sobre ações morais, às vezes, é um sinal de fraqueza moral. Ver Ética Nicomaquea 1113 a . Neste caso comparo esta situação à tão estimada tradição filosófica de Mill, conforme descreve nos seus Essays On Bentham e On Coleridge. Mill afirma que para ser um filósofo é necessário ser introduzido no pensamento filosófico, e afirma também que este era um dos problemas de Bentham como filósofo; ser alguém de fora (an outsider) neste assunto.

${ }^{383}$ Isto inclui os filósofos.
} 
resolvê-los. Por exemplo, caso uma pessoa tenha prometido encontrar um amigo para conversar às cinco, mas o chefe peça para outra pessoa no mesmo horário para discutir o bem-estar de outro funcionário ${ }^{384}$. Se a moralidade costumeira dos princípios secundários não pode resolver este problema, então se deve empregar o princípio da utilidade para resolver a questão ${ }^{385}$. Deve ser lembrado que os princípios primeiros são chamados apenas em casos de conflito com os princípios secundários. Não há casos de obrigação moral nos quais os princípios secundários ou a moralidade costumeira não estejam envolvidos (contudo, na origem da formação destas regras de moralidade está o princípio de utilidade).

Crisp argumenta que as pessoas não deveriam consultar o princípio da utilidade, mas apenas quando os princípios da moralidade costumeira entram em conflito e este trabalho concorda com este argumento. Conforme mencionado, a moralidade costumeira repousa sobre o princípio de utilidade, as regras da moralidade dos costumes estão de tal forma embutidas nos sentimentos morais ${ }^{386}$ e estes dão assentimento de uma maneira tão espontânea a tais regras que os agentes sentem-se obrigados a cumpri-las.

Contudo, segundo mencionado, a educação e a opinião moldadas podem ser empregadas pelas instituições para garantir não apenas que cada indivíduo passe a não conceber a possibilidade de sua felicidade separadamente da felicidade dos outros ou de promover o bem geral (de acordo com Mill a promoção do bem geral deve ser um dos motivos habituais de ação e um dos sentimentos que necessitam ocupar importante espaço da vida de cada ser humano, considerando-se que é parte de sua natureza o hábito e a possibilidade de se transformar ao longo do tempo) $)^{387}$.

Após ser descrito que Mill reconhece tanta importância para a capacidade do indivíduo de se transformar ao longo do tempo, bem como o valor dos melhores arranjos institucionais para por fim aperfeiçoar a educação e o desejo de unidade com os sentimentos para com outros indivíduos, pode ser dito que isto seria não apenas um modelo dinâmico de indivíduo, como também um aperfeiçoamento uma evolução cultural. Mill observou que este sentimento de unidade assim ensinado seria um dos

\footnotetext{
${ }^{384}$ Exemplo de Crisp, 1996.

${ }^{385}$ Mill, 1861, p.214

${ }^{386}$ Lembrando que sentimentos, para Mill, são estados mentais.

${ }^{387}$ Mill, 1861, pár.2.18, 3.1-5, 3.10-11.
} 
sensos de empenho utilitarista. Entretanto, há outro nível de pensamento moral independente do nível da moralidade costumeira e do utilitarismo de ato que se aplica somente quando os princípios secundários entram em conflito que é um nível além da moralidade costumeira que é, de acordo com Crisp, um nível puramente utilitarista de ato ou filosófico, em suas palavras; é um nível que utiliza o princípio de utilidade ou a maximização de felicidade ainda que seja a base de princípios secundários, a diferença aqui é que há a consciência de que o primeiro princípio é aplicado em todas as ações.

Seguindo a interpretação de Crisp da moralidade de Mill, este autor estaria engajado em várias formas do discurso moral. Se alguém ouvisse Mill usando a linguagem moral deveria operar em três níveis, para Crisp: (1) o discurso que não deriva do utilitarismo de ato ou o nível da moralidade costumeira, por exemplo: "Seja Corajoso"; (2) o utilitarismo de ato, por exemplo: o dilema do caso do compromisso com o amigo e (3) o filosófico utilitarismo de ato, conforme descrito no segundo parágrafo do segundo capítulo do Utilitarismo que não é nem mais nem menos do que o princípio da maior felicidade ou o princípio da utilidade aplicado conscientemente às ações. A evidência dos escritos de Mill, segundo descrito nas páginas anteriores deste capítulo comprovam que ele estava claramente preparado para falar e pensar em termos da moralidade costumeira, apesar de que quando ele engaja-se em falar seriamente de onde é derivada a fonte de valor, de onde provém o que torna correto ou errôneo ou uma ação ele não diria que é porque elas derivam do costume. Mill afirmaria que uma ação é correta porque gera prazer, porque torna os afetados por uma ação feliz (confirmação da tese hedonista e Crisp está de acordo com isto). Assim, as ações são corretas ou erradas somente porque elas promovem felicidade ou infelicidade.

Desta forma, não deveria ser assumido que o maior espaço para regras morais no utilitarismo de Mill não deixa espaço para elaboração de novas regras à luz do princípio da utilidade, ao contrário, há este espaço porque é este princípio que anexa valor a estas regras, entretanto elas são revisadas a luz de conflitos e não a todo instante, a cada ação, pois existe uma série de elementos, como sentimentos (que com o tempo podem se tornar morais), hábito, faculdades mais elevadas, capacidade mais elevadas, que tornam o ser humano mais complexo que dão um sentido à palavra humanidade que antes, para Bentham, não era possível verificar, dado que seu agente podia ser comparado 
a um homem frio calculador. Entretanto, Mill não anexa nenhum valor intrínseco à moralidade costumeira, seu valor provém da capacidade que esta tem de gerar felicidade, $\operatorname{prazer}^{388}$ :

"que o código de ética recebido não seja, de modo algum, de direito divino, e que a humanidade ainda tenha muito a aprender sobre os efeitos das ações sobre a felicidade geral, admito, ou melhor, sustento energicamente."[Mill, 1861, p. 212].

Mill admite que os filósofos seguem a moralidade costumeira até o ponto em que podem incrementá-la, mas não significa que tanto os filósofos, quanto os próprios agentes possam e façam isto a cada a ato individual. A revisão da moralidade costumeira é parte do que o próprio Mill faz ao escrever o Utilitarismo, conforme a sociedade progride (quando se vê a sociedade em sua dinâmica), entretanto, ele deixa amplo espaço para a permanência dessas regras morais, quando se toma a sociedade estaticamente e é, precisamente, este espaço que salva o indivíduo teórico de Mill de ser um ser robótico como o indivíduo teórico de Bentham, dotado de uma racionalidade calculadora, utilizada a cada ato.

Logo, é possível concluir que Mill não é um utilitarista de ato puro (pois há espaço para as regras da moral quando os indivíduos estão agindo por hábito), nem um utilitarista de regra, pois muitas vezes os agentes quebram as regras da moralidade costumeira, remontando ao primeiro princípio para aperfeiçoá-las ou para decidir sobre um conflito moral. De acordo com Crisp, Mill é um utilitarista de ato de vários níveis porque ele tem muitos níveis de conhecimento do utilitarismo o que inclui: (1) o nível não utilitarista da moralidade costumeira que aponta regras de ação, como por exemplo: seja corajoso, (2) o nível do utilitarismo de ato que resolve dilemas quanto à moralidade costumeira e (3) o nível do utilitarismo de ato filosófico que inclui estar consciente do primeiro princípio, mesmo quando os princípios secundários estão operando. É possível entender a posição de Crisp e assumir que é bastante plausível, que pode haver estes

\footnotetext{
${ }^{388}$ Mill, 1861, p. 211: “Ora o princípio de utilidade vale para alguma coisa, deve nos permitir sopesar essas utilidades conflitantes entre si e demarcar a região onde uma ou outra prepondera."
} 
vários níveis de compreensão do utilitarismo no que concerne à moralidade e que o princípio de utilidade permeia os três níveis, incluindo o primeiro, conforme é tese deste trabalho, pois, ainda que as pessoas ajam por hábito e sigam as regras morais inconscientemente, no início, tais regras tornaram-se costumes porque geravam prazer (reafirmação da tese hedonista).

Crisp assume, então, que Mill é um utilitarista de ato de muitos níveis, afirmação com a qual este trabalho concorda, ou seja, este trabalho discorda que Mill seja um simples utilitarista de ato, porque denominá-lo assim seria colocá-lo na mesma classe de utilitaristas de Bentham que estabelecem o homem em um tipo de classe, uma espécie de natureza calculadora fria, tão criticada por Mill em muitos escritos ${ }^{389}$. Denominar Mill de utilitarista de ato seria minimizar o papel que a moralidade costumeira possui. Segundo tem-se mostrado esse é um papel especial na sociedade que surge como resposta ao homem mais complexo que se pode depreender dos escritos de Mill. Como consequiência, uma mais complexa sociedade também surge e é por isso que, apesar da tese central de seu utilitarismo concordar com a de Bentham, ainda sim este utilitarismo deve ser mais complexo, dado que aponta diversos caminhos para a vida feliz, dentre eles as próprias regras da moralidade costumeira (embora, repita-se que estes princípios secundários não possuam valor intrínseco, porque derivam seu valor do prazer que podem ocasionar, ainda que os homens possam buscar ou agir inconscientemente, muitas vezes de acordo com os princípios secundários).

Por outro lado, denominar Mill como um puro utilitarista de regra seria esquecer que em casos de conflito entre as regras da moralidade, entre os princípios secundários não só é possível como deve-se apelar para o primeiro princípio, para o princípio da utilidade e seria esquecer, também, que as regras da moralidade não possuem valor intrínseco, mas um valor que tem demonstrado como ser maximizador de bem-estar através de gerações passadas com base no princípio da utilidade, seria não lembrar que de tempos em tempos as regras da moralidade podem ser quebradas para que outras melhores sejam postas no lugar, de acordo com o princípio da utilidade, do ponto de vista de uma dinâmica social - terceiro nível de conhecimento do princípio filosófico de Crisp.

\footnotetext{
${ }^{389}$ Por exemplo no escrito Mill on Bentham de 1838, p. 176.
} 
Assim, afirma-se, neste trabalho, que Mill não é nem utilitarista de ato puro e simplesmente, nem um utilitarista de regra, ele é um utilitarista de ato de muitos níveis nas palavras de Crisp ou um utilitarista mais complexo como afirma-se nesta tese, que é derivado de sua descrição mais complexa dos seres humanos (eles possuem faculdades mais elevadas e por isso procuram prazeres de qualidade mais elevada quando têm a chance que, conforme argumentado, faz com que os indivíduos tomem gosto pelas artes, pelo cultivo intelectual e converta estas conclusões a partir da natureza humana em preceitos da moralidade. Além disso, eles têm a característica denominada hábito ${ }^{390}$, possuem a capacidade melhorar ao longo do tempo e determinadas leis da mente). A característica referente ao hábito permite a constância ou o cultivo da moralidade costumeira para o benefício da sociedade ${ }^{391}$ e a característica de desenvolver o próprio caráter ao longo do estimula um maior espaço para a elaboração das regras morais relacionado, principalmente, à questão do desenvolvimento intelectual.

Conforme tem-se demonstrado, Mill critica Bentham e seu utilitarismo, fortemente, seja no Sistema de Lógica seja em alguns de seus Ensaios, seja no Utilitarismo. Esta é uma razão suficiente para Mill não ser considerado um simples utilitarista de ato como Bentham. O homem de Mill procura maximizar a felicidade como um último fim, ou seja, é um hedonista, mas de uma forma totalmente diferente do ser humano de Bentham, pois ele possui faculdades mais elevadas que só são satisfeitas ou ativadas a partir do cultivo intelectual, da apreciação da arte, da natureza, a partir de características somente humanas, além disso ele tem a possibilidade de agir por hábito e não apenas como um ser robótico que faz cálculos a cada ação. No campo da moralidade ele possui regras a seguir, porque está envolvido em um arranjo complexo com outros indivíduos; a própria formação das leis etológicas é a combinação das leis da mente com as leis empíricas que inclui a explicação da formação do caráter individual e nesta

\footnotetext{
${ }^{390}$ Mill aponta em seu Ensaio sobre Bentham, bem como no Utilitarismo e no Sistema de Lógica a importância de agir por hábito e a importância de agir de acordo com princípios secundários e nem sempre de acordo com os primeiros princípios. Esta afirmação pode ser encontrada respectivamente nas páginas 179 e 190 do ensaio sobre Bentham. Esta característica do ser humano que o permite agir por hábito e construir a moralidade costumeira pode ser encontrada no parágrafo 11 do capítulo quarto do Utilitarismo em muitas passagens do Sistema de Lógica (p. 126, p. 178, p. 184, p. 201), no Ensaio sobre Coleridge p. 204 e em outras passagens.

${ }^{391}$ Mill ressalta que pelo hábito uma pessoa pode cultivar más ações, entretanto, é também através dele que este agente tem a possibilidade de cultivar as boas regras morais, deixando de consultar os primeiros princípios.
} 
explanação do caráter individual estão abarcados traços dos fenômenos sociais também, permitindo uma maior ligação com a sociedade e uma dinâmica no aperfeiçoamento de seu caráter quando comparado ao indivíduo do Bentham, porque o auto-desenvolvimento é uma das características próprias ao indivíduo teórico de Mill.

Com este mais complexo nível de utilitarismo que inclui mais espaço para a formulação de regras morais, como uma necessidade ou como uma resposta para este homem mais complexo (composto por estas novas características que vão além da simples busca por prazer e evitar a dor de qualquer qualidade, viz faculdades mais elevadas, a capacidade de desenvolvimento do caráter como membro da sociedade para o benefício próprio e para o benefício da própria sociedade, o que inclui a preocupação com o bem-estar geral, a qualidade de agir por hábito e as leis da mente, lembrando que todas as características derivam seu valor da capacidade que tem de gerar prazer e evitar a dor, a não ser a própria busca pela felicidade e as leis lógicas da mente).

De tudo que foi dito fica provado que o mais complexo modelo de indivíduo teórico de Mill permite a formulação de um princípio de utilidade mais complexo, ainda que continue sustentando a tese hedonista de Bentham que tudo em política e moral deriva seu valor do prazer e da ausência de dor que muitos outros elementos, como determinadas regras morais, devem ser acrescentados para que se atinja a felicidade ou para que se verifique tal princípio ${ }^{392}$. Ou seja, no utilitarismo de Mill há mais espaço para as regras da moralidade.

\footnotetext{
${ }^{392}$ Esta é a descrição do princípio da utilidade do segundo parágrafo do capítulo 2.
} 


\section{Capítulo V - A Ampliação do Espaço da Moral no Utilitarismo de Mill: uma comparação com a concepção utilitarista de Bentham}

\section{Bentham e sua Ética}

No primeiro capítulo foi argumentado que a tese epistemológica do utilitarismo de Bentham é empirista, uma vez que o conhecimento seria possível a partir da experiência sem o auxílio de princípios transcendentais a priori, desta forma, a partir da empiria, seria possível saber que o gênero humano está sob o governo de dois senhores soberanos, a saber: o prazer e a dor. Em outras palavras, os indivíduos fugiriam da dor e buscariam o prazer e isto seria confirmado pela verificação da experiência. As únicas coisas desejáveis como fins humanos seriam a busca do prazer e evitar a dor. Prazer e dor, para Bentham, seriam os únicos bens ou males em si, respectivamente.

Bentham tem uma teoria da linguagem que ele utiliza como recurso metodológico para compreender o mundo, a partir desta tese empirista (de que todo conhecimento é possível a partir da experiência). Conforme foi afirmado no capítulo primeiro desta tese, bem como na minha Dissertação de Mestrado apresentada em 2007, os indivíduos podem conhecer a partir de duas classes de entidades: a) uma perceptiva e b) uma inferencial, a partir das quais ele se relaciona com ele mesmo com os outros e com o mundo. Afirmou-se no capítulo primeiro desta tese que tais entidades podem ser tanto reais quanto fictícias ${ }^{393}$. Ficou claro que as entidades reais possuem existência na realidade das coisas como as substâncias corpóreas, coisas materiais e impressões sensoriais como o prazer e a dor. Contudo, as entidades fictícias são nomes cuja existência não podem ser atribuída na realidade. São expressões da linguagem que não podem ser expressas gramaticalmente em termos de nomes reais, como os substantivos direito, dever, ética, obrigação, lei, e ética. Direitos e obrigações são ditos existir, porque quando um indivíduo possui uma obrigação ela afeta seu mundo real em certa medida, pois ele precisa cumpri-la, mas a existência desses substantivos não é descrita na realidade das coisas como é feito, como se faz com entidades reais.

${ }^{393}$ Ver Dias, 2007, p.29. 
Bentham realiza esta separação entre nomes reais e ficcionais e depois os une, porque deve existir uma conexão entre ambos para que os nomes ficcionais sejam propriamente entendidos. Em outras palavras, todo termo ficcional precisa manter uma relação com um termo real, uma vez que tais termos podem gerar conseqüências que se traduzem em termos de nomes reais, porque geram prazer ou dor.

Assim, os termos ficcionais podem ser explicados através dos termos reais pelo método de exposição denominado paráfrase. Conforme mencionado no capítulo primeiro deste trabalho e na Dissertação de Mestrado apresentada em 2007, o método da paráfrase é empregado para expor termos cujo significado está em frases ou em proposições. Em seguida, uma outra frase inteira é utilizada para expor a palavra que se deseja explicar. Esta é a diferença para o método de exposição de termos por definição, pois neste método apenas uma frase é empregada para explicar uma palavra ${ }^{394}$.

Conforme explicado anteriormente, o método denominado paráfrase consiste em encontrar uma sentença que contenha o termo ficcional como sujeito, um predicado que descreva uma propriedade do sujeito e um termo de ligação entre eles, após formulada essa sentença, encontra-se uma ou mais sentenças em que o termo ficcional que se deseja explicar não esteja presente e que possua relação com um termo real. Após a formulação dessas sentenças, traça-se um arquétipo que represente o termo ficcional que expressem as sensações de prazer e dor ${ }^{395}$.

Portanto, tem-se em vista que termos ficcionais tenham, sempre, relações com termos reais como prazer e dor. Um exemplo dado referiu-se à explicação do termo ficcional obrigação ${ }^{396}$. Tal exemplo serviu para mostrar como ocorre a explicação de termos ficcionais através de termos reais em minha Dissertação de Mestrado escrita em 2007 e também no primeiro capítulo deste trabalho. A primeira frase construída com o predicado explicando o sujeito e o termo de ligação presente poderia ser: A obrigação é incumbente em um homem. Após a construção desta frase, formula-se outra em que o termo obrigação não apareça, estabelecendo uma relação do termo ficcional obrigação com o termo real dor, como no exemplo: a incumbência traz conseqüências dolorosas aos homens. Finalmente, constrói-se um arquétipo para representar o fato de que a

\footnotetext{
${ }^{394}$ Bentham, 1814, p. 139.

395 Bentham, 1814, p. 87.

${ }^{396}$ Bentham, 1814, p. 89.
} 
incumbência ou a obrigação traz conseqüências dolorosas aos homens. Tal arquétipo poderia ser poderia ser um homem deitado com um peso sobre ele ${ }^{397}$.

Após esta explicação através da paráfrase, fica demonstrado que é possível que os termos ficcionais sejam explicados por meio dos termos reais, que sempre mantenham uma relação com termos reais como prazer e dor. Desta forma, as consequiências dos termos ficcionais seriam expressas por meio das consequiências dos termos reais. Assim, concluiu-se no capítulo primeiro desta tese, bem como, na minha Dissertação de Mestrado escrita em 2007 que os termos ficcionais obrigação, ética, dever, direito, e outros são construções humanas sempre com a possibilidade de serem modificados com a finalidade de gerar mais prazer do que dor para a comunidade como um todo.

Da epistemologia do autor depreendeu-se a tese ontológica que reconhece que prazer, dor e o indivíduo são as entidades reais existentes para fins de análise política. Em outras palavras o que existe é o indivíduo capaz de experimentar duas sensações também reais, quais sejam: o prazer e a dor. Da compreensão da epistemologia, auxiliada por esta teoria da linguagem de Bentham, deduz-se que a natureza humana do indivíduo teórico de Bentham, conforme mencionado, está sob o governo destas duas sensações reais, a saber, o prazer e a dor. Destas afirmações ontológicas seguem algumas conseqüências metodológicas, entre elas a de que a comunidade, para Bentham, nada mais é do que a soma de indivíduos que a compõem ${ }^{398}$.

A partir destas considerações, conforme mencionado no primeiro capítulo desta tese e na minha Dissertação de Mestrado apresentada em 2007, o modelo de indivíduo que se deduziu, a partir do sistema teórico de Bentham foi o seguinte: a) o indivíduo capaz de experimentar duas sensações reais (prazer e dor) é a entidade ontológica fundamental para análise política, pois é o único que possui existência na realidade, b) este indivíduo busca o prazer e foge da dor, é auto-interessado ${ }^{399}$ e c) o indivíduo possui uma razão que calcula que é capaz de efetuar cálculos intertemporais, inclusive no que se refere às conseqüências das ações.

\footnotetext{
${ }^{397}$ Bentham, 1814, p.10.

${ }^{398}$ Bentham 1789, p. 10.

${ }^{399}$ Bentham, 1817, p. 211-212.
} 
Tanto na minha Dissertação de Mestrado apresentada em 2007 quanto no capítulo primeiro justificou-se o modelo de indivíduo teórico de Bentham da seguinte forma: a) a primeira afirmação de que o indivíduo é a entidade ontológica fundamental para análise política diz respeito ao recurso relacionado à epistemologia do autor, descrito acima. A divisão entre termos ficcionais e reais induz à conclusão de que para análise política o que existe é o indivíduo capaz de sentir duas entidades também reais, a saber: prazer e dor ${ }^{400}$. Os outros termos políticos, como comunidade, ética, dever, obrigação, etc, possuem existência apenas quando relacionados a termos reais. A segunda afirmação sobre o fato do indivíduo ser auto-interessado é possível de ser efetuada, pois há mais afirmações que sugerem que o indivíduo age no sentido de maximizar seus próprios interesses. A terceira afirmação refere-se à denominada faculdade intelectual, por Bentham. Tal faculdade teria por principal característica a capacidade de efetuar cálculos, previsões e antecipações das consequiências das ações, com base nas experiências passadas. Esta razão inventou todo um método de estimar os valores dos prazeres e dores das conseqüências das ações dos agentes envolvidos nelas. Conforme mencionado no capítulo primeiro e em minha Dissertação de Mestrado apresentada em 2007, esta razão calcula, prevê, compara e estima os valores de prazeres e dores das conseqüências das ações ${ }^{401}$, sendo que o exercício da razão humana constitui o principal instrumento na condução dos homens à felicidade.

De acordo com a afirmação da minha Dissertação em 2007 e no capítulo primeiro deste trabalho, existem quatro fontes capazes de gerar prazer e dor: a) física, b) política, c) moral e d) religiosa ${ }^{402}$. Se o prazer ou a dor ocorre na vida presente e no curso da natureza, então, o prazer é denominado sanção física. Caso o prazer for esperado de uma pessoa, sob nome de juiz ou que ocupe um cargo político, pode-se dizer que é derivado da sanção política. No caso do poder de gerar prazer ou dor estiver sob a tutela de pessoas que ocupam um lugar de destaque na comunidade, por disposição espontânea, diz-se que o prazer e a dor derivam da sanção moral. Se dependerem de ser superior invisível, quer na vida presente, ou na vida futura, então deriva de sanção religiosa ${ }^{403}$.

\footnotetext{
${ }^{400}$ Bentham, 1789, p. 2.

${ }^{401}$ Bentham, 1834, p.144.

${ }^{402}$ Bentham, 1789.

${ }^{403}$ Bentham acrescenta a sanção religiosa como forma de dialogar com o público de sua época.
} 
Conforme referido no capítulo primeiro desta tese, Bentham ressalta que os prazeres pertencentes a cada sanção são iguais não distintos qualitativamente, uma vez que são sentidos fisicamente ${ }^{404}$, além disso, as pessoas apenas ocupam-se dos prazeres referentes à vida presente. A diferença encontra-se no fato da produção dos prazeres poder ser derivada de fonte moral, política, sendo que ambas têm sua origem na fonte física e nunca, nenhum prazer é distinto em qualidade, podendo ser, todos os prazeres, comparados quantitativamente ${ }^{405}$

Portanto, conclui-se que a sanção física dos prazeres e dores é o fundamento da sanção política, moral e religiosa. Nenhuma destas fontes pode operar senão por meio do prazer ou dor física ${ }^{406}$ ou em outras palavras por meio das forças da natureza. Por este motivo, passa a ser possível comparar, quantitativamente, os prazeres e dores de cada indivíduo, diferenciado-os por sua quantidade (mais prazer, mais dor, menos prazer, menos dor). Bentham, inclusive, apresenta um método para medir a tendência de uma ação a produzir o bem (prazer) ou o mal (dor), baseado no modelo de indivíduo, com uma razão calculadora e capaz de efetuar cálculos intertemporais.

Segundo mencionado no capítulo primeiro desta tese, a mensuração do prazer e da dor inicia-se com considerações sobre os indivíduos atingidos pela ação em questão. Desta forma, para o primeiro indivíduo, o valor de um prazer ou de uma dor será maior ou menor segundo as quatro circunstâncias que se seguem: 1) intensidade, 2) duração, 3) certeza ou incerteza, 4) proximidade ou longinquidade. No que diz respeito à tendência geral da ação, leva-se em conta duas outras circunstâncias, a saber: 5) fecundidade (probabilidade que o prazer ou a dor tem de serem seguidos por sensações de mesma espécie) e 6) pureza (probabilidade que o prazer e a dor possuem de não serem seguidos por sensações contrárias) ${ }^{407}$. A seguir verifica-se a extensão ou o número de indivíduos afetados pela ação em questão. Tendo em vista todos estes elementos, o valor

\footnotetext{
${ }^{404}$ Bentham chama os prazeres de "pathological". Aqueles que não são desta espécie, como os prazeres da mente, são denominados inertes. Sobre isto cito Bentam, 1817, em a Table of Springs of Actions p. 206:" [...] For pathological might here have been put the more ordinary adjunct physical, were it not that, in the case, those pleasures and pains, the seat of which is not in the body but only in the mind, might be regarded as excluded [...]".

${ }^{405}$ Bentham, 1789, em Uma Introdução aos Princípios da Moral e da Legislação p. 20.

${ }^{406}$ Bentham, 1789, em Uma Introdução aos Princípios da Moral e da Legislação p. 21.

${ }^{407}$ Conforme afirmado no capítulo primeiro desta tese ambas as circunstâncias não são propriedades do prazer ou da dor. Portanto, só devem ser consideradas na avaliação da tendência do ato.
} 
do prazer e da dor será maior ou menor conforme as sete circunstâncias: 1) intensidade, 2) duração, 3) certeza ou incerteza, 4) proximidade ou longinquidade, 5) fecundidade, 6) pureza, e 7) extensão (número de pessoas as quais se estende o respectivo prazer ou dor $^{408}$ ). Desta forma, mencionou-se que para haver avaliação exata das consequiências de uma ação qualquer que afeta os interesses de uma comunidade, procede-se começando por qualquer pessoa cujos interesses pareçam ser mais imediatamente afetados pelo ato e levam-se em conta os seguintes elementos: 1) o valor de cada prazer que se manifesta como gerado pelo ato em primeira instância (variará segundo a intensidade, duração, proximidade ou longinquidade, certeza ou incerteza), 2) faz-se o mesmo para a dor, 3) o valor de cada prazer produzido pelo ato após o primeiro prazer, que é a fecundidade do primeiro prazer (e a impureza da primeira dor), 4) realiza-se o mesmo procedimento para a dor, 5) somam-se todos os valores dos prazeres de um lado e os valores de todas as dores do outro. O balanço, quando favorável ao prazer, aponta para a consequência boa do ato para o primeiro indivíduo. Quando o balanço favorece a dor indica a tendência má do ato para o mesmo indivíduo, 6) em seguida realiza-se uma contagem do número de pessoas envolvidas pela ação e repete-se o procedimento mencionado acima em relação a cada um dos agentes, em seguida soma-se $\mathrm{e}^{409} \mathrm{o}$ número de graus de tendência boa com relação a cada um dos indivíduos, faz-se o mesmo para cada indivíduo cuja tendência do ato é má, em conjunto e logo após procede-se ao balanço. Este se for favorável ao prazer mostra a tendência boa geral do ato. Caso o balanço pesar para a dor, será demonstrada a tendência má geral do ato ${ }^{410}$.

Considerando este balanço, para que se tenha em vista a tendência geral do ato, é necessário que se leve em conta o número de pessoas afetadas e, portanto, requer-se que o legislador ou um homem do governo esteja considerando o procedimento para julgar se uma ação é justa ou não, com a finalidade de evitar injustiças. Bentham ressalta que não se pode exigir que este balanço seja observado com uma exatidão total. Apesar de se esperar que este seja o procedimento de um espectador, teoricamente, imparcial (em relação às pessoas que são afetadas pelo ato), como o governo, sabe-se que esta constitui

\footnotetext{
${ }^{408}$ Note-se que a soma dos prazeres e dores de indivíduos só é possível porque os prazeres sentidos por cada um são iguais, diferindo apenas com relação às sete circunstâncias mencionadas .

${ }^{409}$ Conforme mencionado no primeiro capítulo é possível somar as tendências boas e más dos atos, porque qualitativamente os prazeres, sentidos por cada indivíduo, são ditos comparáveis fisicamente.

${ }^{410}$ Bentham, 1789, p. 24.
} 
a racionalidade do agente teórico de Bentham, uma vez que este indivíduo é capaz de realizar cálculos intertemporais, como bem se demonstrou através do balanço que ele é capaz de realizar para julgar a justeza de uma ação, embora não esteja obrigado a considerar os outros na efetivação de suas ações.

Segundo referido, anteriormente, a racionalidade deste indivíduo teórico de Bentham é o principal instrumento capaz de conduzi-los à busca da felicidade. A partir de cálculos complexos eles podem não apenas avaliar a justeza de uma ação como identificar os meios necessários à maximização de seus prazeres e isto é feito em cada ação. Ora, esta conclusão é bastante plausível, afinal o que impediria o indivíduo teórico de Bentham de realizar um cálculo racional a cada ação?

Portanto, este método de mensuração dos prazeres e dores para avaliar a tendência geral de um ato é importante consideração acerca da natureza do indivíduo. $\mathrm{O}$ indivíduo governado pela capacidade de experimentar prazer e dor realiza cálculos em todas as ações para maximizar seu prazer e minimizar sua dor. A natureza do indivíduo teórico de Bentham corresponde ao que foi apresentado acima e no capítulo primeiro deste trabalho, este é o indivíduo racional do autor e esta racionalidade será empregada como principal instrumento a ser considerado nas decisões políticas e morais do sistema do autor. A moralidade de Bentham, assim como a moralidade de Mill, será derivada da natureza do indivíduo.

Tendo em vista a natureza humana do indivíduo teórico de Bentham descrita até aqui e a racionalidade calculadora deste indivíduo, derivada desta natureza. O princípio de utilidade, de Bentham, é construído como reconhecendo que este agente está sob o governo do prazer e da dor ou busca maximizar o prazer e minimizar as dores, e, portanto, se estabelece como uma regra ou uma norma ética que ressalta que é correto que os indivíduos busquem os prazeres e evitem as dores, bem como é errôneo evitar o prazer e buscar as dores. Esta seria, portanto, a norma de ação para um indivíduo, bem como serviria como guia de ação para o governo analisar as ações de todos os indivíduos afetados por um ato.

Apresenta-se a seguir o princípio de utilidade formulado por Bentham da mesma forma como foi apresentado no capítulo primeiro deste trabalho: 
“[...] Por princípio da utilidade entende-se aquele princípio que aprova ou desaprova qualquer ação, segundo a tendência que tem a aumentar ou a diminuir a felicidade da pessoa cujo interesse está em jogo, ou, o que é a mesma coisa em outros termos, segundo a tendência a promover ou a comprometer a referida felicidade. Digo qualquer ação, com o que tenciono dizer que isto vale não somente para qualquer ação de um indivíduo particular, mas também de qualquer ato ou medida de governo [...]”. Ou, em outros termos, o princípio da utilidade é explicado da seguinte forma: “[...] O princípio que estabelece a maior felicidade de todos aqueles cujo interesse está em jogo, como sendo a justa e adequada finalidade da ação humana, e até a única finalidade justa, adequada e universalmente desejável: da ação humana, digo, em qualquer situação ou estado de vida, sobretudo na condição de um funcionário ou grupo de funcionários que exercem os poderes do governo [...]”.(BENTHAM, 1789, p.10).

Este é o princípio que funda a moralidade de Bentham, bem como o princípio que reconhece que os únicos bens ou males em si são os prazeres e as dores, respectivamente, e as únicas finalidades justas a serem perseguidas pelos seres humanos, todos os motivos de ação, como a simpatia e a antipatia, por exemplo, poderiam ser traduzidos em prazeres e dores. Todos os meios para alcançar a felicidade não seriam senão outra coisa do que prazer e dor. Mill ressalta que esta seria uma confusão de Bentham, conforme foi exposto no capítulo terceiro e quarto deste trabalho, além de Bentham partir de uma natureza humana demasiado simplificada e, portanto, muito longe para explicar o ser humano real, o autor haveria confundido tudo aquilo que o ser humano busca e tem prazer com o próprio prazer, por isso ressalta Mill: “A felicidade não é uma idéia abstrata, mas um todo concreto, e essas são algumas de suas partes. E o padrão utilitarista sanciona e aprova que assim seja.”[Mill, 1861, p. 235]. 
Voltando à concepção de natureza humana do indivíduo teórico de Bentham e ao seu primeiro princípio que funda a moralidade: o princípio de utilidade, conclui-se que o correto é buscar o prazer e é errôneo buscar a dor, bem como os únicos bens em si são os prazer e os únicos males em si são as dores. Além disso, sabe-se que estes prazeres e dores não possuem qualquer distinção de qualificação, como possuem para Mill, portanto, são totalmente comparáveis quantitativamente, sendo distinguidos, conforme foi demonstrado através dos cálculos dos prazeres e dores, apenas de acordo com sua 1) intensidade, 2) duração, 3) certeza ou incerteza, 4) proximidade ou longinquidade, 5) fecundidade, 6) pureza, e 7) extensão (número de pessoas as quais se estende o respectivo prazer ou dor.

A partir destas considerações sobre a natureza humana do indivíduo teórico de Bentham e do primeiro princípio ou preceito moral denominado o princípio de utilidade de Bentham, segue a definição de ética para o autor:

O significado de ética, em sentido amplo, para o autor, é um princípio que deve conduzir os homens à felicidade ou a um balanço que produza mais prazer do que dor, em outras palavras a definição de ética visa ao maior benefício de todos e coincide com o próprio significado de princípio de utilidade, como não poderia deixar de ser. A seguir apresenta-se, novamente, o significado de ética, para o autor: “[...] Ética em geral pode ser definida como a arte de dirigir as ações humanas na produção da maior quantidade possível de felicidade da parte cujo interesse está em jogo [...]”. [Bentham, 1789, p. 69].

Considerando que a definição de ética coincide com a própria definição do princípio de utilidade, a pergunta que é colocada aqui tal como foi colocada o capítulo primeiro deste trabalho é: qual é o conteúdo que deve apresentar as normas do agir moral? De acordo com Bentham, o conteúdo das normas presentes na ética só pode ser aquele que esteja de acordo com o princípio de utilidade, uma vez que uma regra só pode ser dita correta caso leve à obtenção de mais prazer do que dor e só pode ser considerada errônea caso gere mais dor do que prazer, quando feito o balanço da tendência geral do ato.

Assim, a cada ação este indivíduo com esta razão calculadora efetuará uma revisão das regras dos costumes fazendo com que elas passem pelo crivo do princípio de 
utilidade, pois os sentimentos, para Bentham, não são válidos para julgar regras morais, mas apenas e tão somente a razão calculadora.

Segundo pode-se deduzir a respeito dessas afirmações sobre a ética, não existem ações boas ou más em si mesmas, motivos de ações bons ou maus em si, costumes ou tradições boas ou más em si mesmas. De acordo com a ontologia do autor, o que existe e deve ser levado em conta são os prazeres e dores derivados das conseqüências das ações. Somente as conseqüências das ações podem ser julgadas, uma vez que apenas elas geram prazeres ou dores nos indivíduos ${ }^{411}$.

Os vícios e virtudes são assim denominados conforme as conseqüências que produzem para a geração de prazer ou dor ou segundo a potencialidade que têm para ocasionar prazer ou dor ${ }^{412}$. Desta forma, o bem moral pode ser pensado ou dito existir conforme sirva de instrumento na produção de um prazer físico.

Em outras palavras, as normas que constam na moralidade de Bentham devem estar sempre de acordo com o princípio de utilidade, sempre de acordo com um balanço entre prazer e dor, porque este princípio é formulado com base na razão calculadora que consta na natureza humana deste indivíduo.

Se este indivíduo questiona a toda ação, as regras do costume, transformando-se em uma espécie de máquina de fazer cálculos a todo instante, onde fica o espaço das regras fixas a serem aplicadas com força coercitiva? A legislação é, propriamente, o espaço da aplicação de normas (que se estabelecem também por um cálculo), com força coercitiva, sendo que as regras que não constarem da legislação sobrarão para o campo da moral.

É interessante notar que a racionalidade calculadora do agente, a natureza do indivíduo teórico de Bentham está presente em todas as etapas do raciocínio que se faz para entender como o indivíduo é conduzido na sua busca à felicidade, seja através da ética, seja através de outros meios. Para entender como as regras repousarão sobre a ética ou sobre a legislação não será diferente, será o princípio de utilidade, respeitando a natureza calculadora do indivíduo que ditará o raio de ação de um campo e de outro.

\footnotetext{
${ }^{411}$ Bentham, 1789, p.69.

412 Bentham, 1814, p. 206.
} 
O papel da natureza humana, portanto, é fundamental para que se compreenda de que maneira o princípio da utilidade é construído, de que maneira o cálculo racional é efetuado na busca da felicidade (balanço entre prazer e dor) e de que forma este mesmo balanço é efetuado para manter as regras como regras da lei ou regras da moralidade e assim delimitar o espaço da moral de Bentham.

Tendo em vista que a racionalidade de Bentham e a maneira como a ética é identificada com a felicidade dos indivíduos, pode-se dizer que a legislação também tem por objetivo salvaguardar tal felicidade, em outras palavras, os pontos em comum de ambas são (conforme mencionado no primeiro capítulo e em minha Dissertação de Mestrado defendida em 2007): a) dizem respeito à felicidade e ações de cada um e b) as pessoas cuja felicidade devem ter em vista, bem como os indivíduos cuja conduta devem ocupar-se, são os mesmos.

Levando em conta as três áreas da ação humana: a) ação com ausência de interações (prudência quando maximiza prazer), b) interações positivas (beneficência quando gera felicidade, prazer no cômputo do balanço) e c) interações negativas (probidade quando a dor não é ocasionada), sabe-se que a legislação tem como objetivo garantir a probidade, ou a ausência do cometimento de injúrias, enquanto os grandes campos da ética são garantir a prudência e a beneficência.

Adiantando, de maneira breve, a solução que Bentham sugere para as regras que constam do campo da ética, tem-se que: a ética tangencia a probidade, ou o ramo em que os indivíduos podem gerar injúrias uns aos outros, somente nos casos em que não for benéfica a aplicação de leis, ou seja, apenas quando mais dor do que prazer for ocasionado a partir do emprego de normas formais, ou seja, isto é decido a partir de um balanço entre prazer e dor, utilizando o princípio de utilidade derivado da racionalidade calculadora do indivíduo. A legislação, de outra parte, não deve interferir nos casos relativos à prudência (casos em que não há interação entre indivíduos), por uma questão de eficiência (mais uma vez de cálculo), pois: a) o legislador não pode elaborar leis sobre a questão, dado que não pode entender mais sobre os interesses de um indivíduo do que ele próprio e b) a ação coercitiva do governo, neste caso, pode instaurar um sentimento de perseguição aos costumes sociais, reduzindo os motivos sociais (por exemplo, diminuição da benevolência e amor à amizade) nos indivíduos. No que diz respeito ao 
agir positivo, a área legal poderá intervir, somente, em casos específicos, como o salvamento de alguém, sem prejuízo próprio. Em outros casos do agir positivo, a aplicação da legislação não faz sentido, pois descaracteriza a natureza do termo beneficência que diz respeito a uma disposição livre do agir de forma a ocasionar $\operatorname{prazer}^{413}$.

Ao fim deste tópico será dada uma explicação mais detalhada sobre a separação entre os campos de abrangência da ética e da legislação, no que concerne aos três tipos de ações acima descritas. O guia desta separação da atuação de ambos os temas (ética e legislação) será, em todos os casos, o princípio de utilidade (balanço entre prazer e dor das consequiências das ações), utilizando a racionalidade calculadora pertencente ao agente teórico de Bentham, para provar que não há diferença de natureza entre o conteúdo da regras que constam na moral e na legislação, ou seja, a diferença reside em cálculo de custo benefício.

Considerando a breve explanação dada acima sobre as distinções entre a ética e a legislação, depreende-se que apresentam as seguintes distinções (segundo explicitado no capítulo primeiro e em minha Dissertação de Mestrado apresentada em 2007): a) os atos com os quais ambas devem ocupar-se, embora sejam convergentes, não são perfeitamente e inteiramente os mesmos, pois o balanço entre prazer e dor delimitará sua distribuição entre os campos de atuação da legislação e ética b) no que toca a legislação existem casos em que o legislador não deve tentar dirigir a conduta dos vários outros membros da comunidade (eventos relativos à prudência, beneficência e parte dos casos de probidade).

Tais diferenças entre ambos os temas ocorrem, pois o princípio de utilidade inscreve, a partir de um cálculo de custo benefício para a sociedade, o raio de atuação da ética e da legislação. Por ser mais benéfico à sociedade, a prudência e beneficência ficam sob o escopo da ética, enquanto que a probidade permanece sob o raio de ação da legislação, pelo mesmo motivo. Ora, isto é o mesmo que dizer que o princípio da utilidade determina, através de um cálculo de custo benefício, o raio de atuação de ambos os temas.

${ }^{413}$ Bentham, 1789, em An Introduction to the Principles of Moral and Legislation p.148. 
Contudo, no que diz respeito ao agir negativo (abster-se ou não de gerar dor) será mostrado, que, para Bentham, o legislador não pode impedir todos os atos prejudiciais (ofensas) praticados por uma pessoa contra a comunidade, pois os malefícios gerados podem ser maiores do que os benefícios resultantes.

Desta forma, além dos campos que são próprios da ética, como a prudência e beneficência, e assim, a partir de um cálculo da razão, no sistema de Bentham, cabe analisar quais são os casos de intervenção da ética que seriam próprios do setor legal. Em outras palavras, cabe analisar quais casos não se deve punir, mas apenas aplicar a ética, através de uma sanção moral ${ }^{414}$.

Antes de efetuar análise de tais casos, uma pergunta torna-se pertinente: qual o princípio que deve estar por traz do argumento de que um caso próprio da legislação não deve estar sob sua abrangência, mas antes sob o escopo da ética?

Do mesmo modo que o princípio da utilidade, através de um cálculo racional, fruto da natureza humana, decide que a prudência e beneficência devem ser matéria da ética e que a probidade deve ser mantida no escopo da legislação, é possível sustentar a hipótese de que será o princípio da utilidade (análise de custos e benefícios da punição, aplicada à sociedade, ou balanço entre prazer e dor) que determinará os limites aos quais o setor penal, legislativo pode atuar. Assim, os tipos de atos que podem causar mal não devem ser tocados pela lei, por aplicação do próprio princípio de utilidade, por aplicação de um cálculo racional, constituem o limite do campo da ética para com a legislação.

Levando em conta que é um cálculo racional que estabelece se uma regra, para Bentham, ficará restrita ao campo da ética ou da legislação e tendo em vista que a regra (que fica restrita ao campo da ética ou da legislação) não possui diferença de natureza, segue-se a condução da resposta sobre a distinção entre a ética e a legislação, no que concerne aos casos em que não cabe punir, com vistas a delimitar ambos os campos, a saber: a ética e a legislação.

\footnotetext{
${ }^{414}$ É interessante ter em vista que as regras da ética não possuem um instrumento de coerção como possuem as regras da lei, mas possuem um instrumento de coação de sanção moral capaz de produzir prazer ou dor, que se encontra nas mãos de pessoas que por acaso ocupem um lugar de destaque na comunidade.
} 
2. Casos em que não cabe punir legalmente no sistema de Bentham

O objeto geral no qual todas as leis têm em comum diz respeito ao aumento do montante total de felicidade da comunidade e, portanto, em primeiro lugar, excluir cada coisa que tende a diminuir a felicidade. Em outras palavras, eliminar o mal. Contudo, toda legislação e punição geram um mal. De acordo com o princípio da utilidade, de acordo com um cálculo racional, um mal é admitido somente para impedir ou excluir um mal ainda maior.

Tendo em vista esta consideração sobre o mal, Bentham cria um instrumento metodológico adicional para entender quais são os males que resultam da punição. O objetivo é subdividi-los, para que sejam analisados à luz dos casos em que não cabe punir, para, então, entender quais dos casos que seriam da jurisdição da legislação que cabem ficar restritos à ética.

De acordo com a classificação de Bentham (segundo foi explicado no capítulo primeiro desta tese e em minha Dissertação de Mestrado de 2007), o mal da punição pode dividir-se em quatro partes, por meio das quais diferentes conjuntos de pessoas são afetados: 1) o mal da coerção ou a dor causada em um homem por impedi-lo de realizar um ato, 2) o mal da apreensão, 3) o mal do sofrimento ou a dor que um homem sente em virtude da punição, a partir do momento em que começou a suportá-la e 4) a dor da antipatia ou outros males derivativos resultantes de pessoas que estão em conexão com as várias classes de sofrimentos acima mencionadas. Dentre estes quatro tipos de males: a) o primeiro será maior conforme a natureza do ato que o indivíduo é impedido de realizar e b) os três últimos serão maiores conforme a natureza da punição que acompanha a respectiva ofensa. De outra parte, o mal causado pela ofensa também será maior ou menor conforme a natureza dela. A proporção entre crime e punição variará conforme a ofensa efetuada. Tudo é resultado de um cálculo racional.

Considerando as dores causadas pela punição, torna-se interessante verificar quais casos não são passíveis de punição legal, para que estejam de acordo com o princípio da utilidade (balanço favorável ao prazer) e permaneçam como regra da ética. É importante ter em conta que a dor causada pela punição deve ser, em todos os casos, a menor possível, suficiente apenas para desestimular crimes, quando houver vantagem 
para a sociedade (quando o balanço entre prazer e dor apontar para o benefício da sociedade). Nos casos em que não houver benefício para a sociedade, não é eficiente a aplicação da lei ou de punições.

A verificação de que alguns casos não devem ser abrangidos pela lei ou pela punição fornece importantes respostas sobre a limitação da atuação de ação da legislação e sobre a abrangência da atuação da ética, no que diz respeito à interação entre indivíduos, de forma negativa. Em outros termos, questiona-se: quais casos não devem ser tocados pela lei? Dentre os casos que não devem ser tocados pela lei, quais constituem escopo da ética, para Bentham?

Levando em conta estas questões, é descrita, abaixo, a análise dos casos em que a punição legal não deve ser aplicada, segundo o princípio da utilidade (balanço favorável ao prazer ou à minimização de dor ${ }^{415}$ :

a) No caso em que a aplicação da pena é infundada (groundless): $\mathrm{a}_{1}$ ) não há mal a ser evitado e $\mathrm{a}_{2}$ ) o ato não causa mal ao todo.

b) No caso em que a punição é ineficaz (inefficacious), em outros termos, quando nenhuma punição pode evitar o mal a ser causado.

c) No caso em que a aplicação da pena não é proveitosa (unprofitable), ou muito onerosa, em outras palavras, quando o mal gerado pela punição seria maior do que o mal que se poderia prevenir, em termos financeiros.

d) Nos casos em que a punição é desnecessária (needless): quando o mal pode ser impedido ou cessar por si só, sem a punição, o que é o mesmo que dizer cessar a uma taxa mais barata.

a) Casos nos quais a aplicação da pena é infundada ${ }^{416}$

São casos em que nunca houve um mal, quando nenhum mal foi produzido a algum indivíduo pelo ato em questão. Em outras palavras, algumas vezes, um ato foi considerado danoso, mas na ocasião em que ocorre a pessoa afetada dá sua permissão

\footnotetext{
${ }^{415}$ Bentham, 1789, em An Introduction to the Principles of Moral and Legislation p. 83.

${ }^{416}$ Bentham, 1789, em An Introduction to the Principles of Moral and Legislation p. 83.
} 
para que ocorra, da forma como ocorreu. Contudo, se há consentimento a legislação ou punição não pode interferir em tal caso, pois ninguém é melhor juiz do que é melhor para si do que a própria pessoa afetada por um ato (ninguém melhor do que o próprio indivíduo para efetuar o cálculo daquilo que lhe ocasiona prazer) ${ }^{417}$.

Pode-se dizer que a pena é considerada infundada quando o mal gerado pela ação é superado por um prazer. Em outros termos, embora um mal tenha sido gerado por um ato, este se fazia necessário para a produção de um benefício de maior valor. Este é o caso em que um mal é efetuado no exercício de vários tipos de poderes necessários a serem estabelecidos em todas as comunidades, a saber: judicial, militar e supremo ${ }^{418}$. Ou seja, para implantação destes poderes custos (ou males) são impostos, sendo, contudo, superados por prazeres ou benefícios gerados.

Ademais, as penas serão consideradas infundadas caso haja a certeza de uma compensação adequada. Esta contrapartida pressupõe dois aspectos: 1) a ofensa é tal que admite adequada compensação e 2) tal compensação certamente virá em futuro próximo $^{419}$.

b) Casos em que a punição é ineficaz ${ }^{420}$

Os casos em que a punição é ineficaz referem-se aos casos em que um ato pernicioso foi cometido antes que constasse na legislação como ofensivo. $\mathrm{O}$ autor ressalta que o juiz não pode ao seu bel prazer condenar um ato, antes que conste na legislação. Outro caso em que a punição é avaliada como ineficaz diz respeito às situações em que a provisão penal, então estabelecida, não é conduzida ao conhecimento da pessoa à qual se pretende aplicar a pena.

A pena é também considerada ineficaz nos casos em que a provisão penal tenha sido conduzida ao conhecimento do indivíduo ao qual se pretende aplicar a pena, contudo, não surtirá efeito algum sobre ele, com respeito a impedi-lo de efetuar o ato que se quer impedir. Mostra-se a seguir alguns exemplos: 1) na infância, quando o homem

\footnotetext{
${ }^{417}$ Bentham, 1789 em An Introduction to the Principles of Moral and Legislation p. 84.

${ }^{418}$ Ibid.

${ }^{419}$ Bentham admite que esta última suposição não pode ser verificada de fato, mas apenas vislumbrada.

${ }^{420}$ Bentham, 1789, em An Introduction to the Principles of Moral and Legislation p. 83.
} 
ainda não atingiu o estado de disposição mental, o qual a lei possua alguma possibilidade de influenciar sua conduta, 2) no caso de insanidade, 3) no caso de intoxicação, como uso de drogas, em que o agente aja contrariamente à sua vontade.

A punição se faz ineficaz, também, quando o conjunto de penas não pode ter efeitos em relação ao indivíduo que está em vias de cometer o ato em questão, porque o indivíduo não sabe que o ato se relaciona ao número de penas previstas. Exemplos: 1) no caso da não intencionalidade, em que o indivíduo não pretende efetuar o ato, mas o fará sem intenção, 2) quando o indivíduo está inconsciente, quando o indivíduo sabe que cometerá o ato, porém não sabe quais as circunstâncias materiais que o envolvem, tornando a tendência de produzir mal oculta para ele e 3) no caso de suposições errôneas, em que a partir de certas circunstâncias consideradas, o indivíduo pensa que sua ação não produzirá dor ou gerará um bem maior do que o mal que possa ocasionar.

Mesmo nos casos em que há uma completa influência da lei sobre um agente, a influência de outra causa predominante que obrigue o indivíduo a praticar um determinado ato, faz com que a punição torne-se ineficaz. Como ilustração serve casos em que os males aos quais um indivíduo tenha que resistir sejam grandes. Isto pode aparecer: 1) nos casos de danos físicos causados pelos poderes da natureza e 2) no caso de um mal ameaçador causado por outro homem (como a partir da sanção moral e religiosa podendo ser maior do que qualquer pena que o legislador possa imprimir).

Finalmente, a pena é, ainda, considerada ineficaz, quando a cláusula penal exerce uma influência completa sobre a vontade do agente, porém suas faculdades físicas o impedem de agir de acordo com sua vontade. Em outras palavras, suas condições são involuntárias.

c) Casos em que a punição é não proveitosa (não lucrativa) ${ }^{421}$

Nos casos em que o mal que resulta da punição é maior do que o bem que se quer auferir dela, a punição torna-se não proveitosa (excessivamente custosa). O mal da punição, neste caso, é maior do que o mal da ofensa, somando-se a ela, sem que um benefício suficiente seja gerado, por influência de algumas circunstâncias. Por exemplo:

${ }^{421}$ Bentham, 1789, em An Introduction to the Principles of Moral and Legislation p. 83. 
a) nos casos em que os serviços penais se tornam extremamente onerosos, privando a comunidade de se beneficiar de outros serviços estatais, b) quando a sociedade não deseja punir determinado ofensor, em uma dada circunstância, da maneira corrente.

d) Casos em que a punição não se faz necessária ${ }^{422}$.

A punição não se faz necessária quando o propósito é colocar um fim a uma determina ação a uma taxa mais barata do que utilizando a punição legal, como, por exemplo, pela instrução, informando o entendimento ou pela influência direta na vontade. Estes são os casos em que indivíduos disseminam idéias perniciosas no que concerne a questões de dever, quaisquer que sejam os tipos de dever (políticos, morais ou religiosos). Bentham ressalta, que em casos como este, em havendo necessidade, o governante deve agir sempre com a caneta e não com punição ${ }^{423}$. Indicar que o governante aja com a caneta e não com a punição não impedirá que muitos autores escrevam teorias com consequiências maléficas à sociedade, mas evitará que os agentes tomem certas teorias como verdadeiras.

Tendo em vista os casos em que não cabe aplicação da legislação, perguntase, então, onde se encontra a delimitação entre a legislação e a ética, no que concerne aos casos de interação negativa entre indivíduos (abstenção ou não de gerar dor), para o indivíduo de Bentam? A resposta tem sido conduzida fundamentada em um balanço entre prazer e dor, com base em um cálculo racional derivado da natureza humana do indivíduo teórico de Bentham extraída a partir do método geométrico. O cálculo racional ditará em quais destes casos a legislação não deve atuar, mas apenas e tão somente as regras da ética. Em outras palavras, o cálculo racional dita quais as regras que permanecerão sob o escopo da legislação e quais permanecerão sob o escopo da ética, restando claro que não há diferença de natureza entre elas. ${ }^{424}$

\footnotetext{
${ }^{422}$ Bentham, 1789, em An Introduction to the Principles of Moral and Legislation p. 84.

${ }^{423}$ Bentham, 1789, em An Introduction to the Principles of Moral and Legislation p. 83.

${ }^{424}$ Bentham, 1789, em Uma Introdução aos Princípios da Moral e da Legislação p. 144.
} 
3. O estabelecimento da fronteira entre a ética e a legislação, para Bentham e uma Introdução à Ética de Mill

É necessário que se estabeleça a fronteira entre a ética e a legislação, para Bentham, para que se entenda, que uma vez dadas as relações sociais, quais os tipos de regras que ficarão restritas à ética. É interessante notar, também, que o guia desta delimitação, para o autor, é sempre o balaço entre o prazer e a dor, através da razão calculadora do indivíduo, pertencente ao indivíduo teórico de Bentham. Ou seja, um apelo ao primeiro princípio é sempre feito para que sejam estabelecidas as regras da ética.

A maneira como a legislação interfere nas vidas das pessoas é através da punição (ou recompensa em casos mais raros) ${ }^{425}$. Os casos em que a sanção política ou legislação não tem a necessidade de ser aplicada foram mencionados no tópico anterior e referem-se à quando a punição é infundada ou quando a punição é ineficaz, quando a punição é não proveitosa e quando não há necessidade de punição. Entretanto, em alguns destes casos, em que a legislação não deve interferir, a ética pode ser aplicada.

Conforme a visão de Bentham, será feita uma análise de todos estes eventos, para entender se ao mesmo tempo em que não há espaço para interferência da legislação há espaço para interferência das regras da ética. Quando a punição é infundada (casos em que nenhum mal foi cometido) fica claro que a interferência da ética também não é necessária. Isto acontece porque nenhum mal foi cometido, ou em outros termos, o ato não corresponde a uma ofensa ${ }^{426}$.

Os eventos em que a punição configura-se como ineficaz devem ser divididos em duas classes: ao momento da aplicação da punição, em outros termos, a pena imposta deveria ocorrer em outro instante que não o da denúncia, para que se tornasse eficaz. Estas ações devem ficar, portanto, tanto sob a abrangência da coerção legislativa (não no momento do ato, mas em outro instante), quanto serem vigiadas pela sanção moral (em outras palavras, podem compor regras da ética). No que concerne à outra classe de atos às quais a punição é ineficaz, é possível afirmar que tal classe também refere-se à estranheza das circunstâncias que a acompanham. Estas

\footnotetext{
${ }^{425}$ Bentham, 1789, em An Introduction to the Principles of Moral and Legislation p. 144 nota I.

${ }^{426}$ Bentham, 1789, em An Introduction to the Principles of Moral and Legislation p. 144.
} 
circunstâncias são de uma natureza tal que não deixam espaço para a aplicação de punição legal ou para a influência da ética. Tais casos referem-se a atos cometidos por crianças, loucos ou bêbados ou eventos em que a pessoa que cometeu o ato não tinha intenção, não tinha consciência, fez suposições errôneas ou casos em que existe impedimento físico ao exercício do ato de acordo com sua vontade. Nestas situações, nem os ditames da legislação ("thunders of law") (Bentham, 1789 p.145), nem os cochichos ("whispers of morality") (Bentham, 1789 p.145) da moralidade podem impedir o cometimento de algum mal ${ }^{427}$.

Os eventos em que as punições são não proveitosas ou não lucrativas (ou, em outros termos, extremamente custosas) representam a grande área de influência da ética, no que concerne ao agir negativo, para além do agir do indivíduo para consigo mesmo (ação que não envolve outros indivíduos) e do agir que gera benefícios para com outros. No caso em que uma punição é muito dispendiosa é porque o mal gerado pela punição excede o benefício auferido. $\mathrm{O}$ mal da punição se distingue de quatro maneiras: a) o mal da coerção, b) o mal da apreensão, c) o mal do sofrimento e d) os males derivados que atingem pessoas que estão em conexão com indivíduos que sofrem as penas. No que concerne aos três primeiros tipos de males, é possível afirmar que os indivíduos podem ser considerados em dois grupos: a) pessoas que realmente realizaram ou estiveram prontas a realizar o mal e necessitam ser impedidas de cometê-lo e b) agentes que podem ter efetuado ou ter estado prontos a efetuar outros atos perniciosos, por terem medo de ser envolvidos nos atos proibidos efetuados pelo primeiro conjunto.

De acordo com Bentham, somente o primeiro conjunto de pessoas constitui perigo à comunidade, e, portanto, deve ser objeto de interferência da ética (regras de ação que estejam de acordo com o princípio da utilidade, ou de acordo com a felicidade da maioria). O segundo conjunto de pessoas, por ser inofensivo, não deve ser objeto da ética, nem tão pouco da legislação.

Desta forma, a punição quando aplicada ao primeiro conjunto de pessoas pode ser dita não proveitosa ou lucrativa em dois sentidos: 1) pelos custos que pode ocasionar e 2) pelo risco de abranger inocentes na condenação ${ }^{428}$.

\footnotetext{
${ }^{427}$ Bentham, 1789, em An Introduction to the Principles of Moral and Legislation p. 145.

${ }^{428}$ Bentham, 1789, em An Introduction to the Principles of Moral and Legislation p. 145.
} 
O primeiro caso depende de uma proporção entre o mal da punição e o benefício gerado por ela. Neste caso a punição deve ser impedida, uma vez que os custos da punição superam os benefícios ocasionados por ela.

Ainda no que concerne aos eventos em que o mal causado pela punição supera o benefício gerado por ela, há ocasiões particulares em que a punição parece incerta ao infrator, quais sejam: 1) quando não há suficiente promulgação da lei, 2) devido a circunstâncias particulares em que atuam motivos sedutores que levam os indivíduos a cometerem crimes não importando os custos da punição e 3) pelo fato de as circunstâncias poderem influenciar a sensibilidade dos indivíduos expostos à ação criminosa.

A ofensa será cometida não importa qual a magnitude da pena nos eventos em que os motivos sedutores são fortes e a sensibilidade do agente é alterada conforme as circunstâncias. Esta infração poderá ser detectada e punida, mas para fins de exemplificação às outras pessoas pertencentes da comunidade (o que constitui o principal objetivo das penalidades) a punição não terá utilidade, dado que a utilidade de uma punição depende da diminuição futura dos mesmos casos de delinqüência. Desta forma, se a punição não parecer ameaçadora, especialmente, aos olhos daquele que é tomado pelos motivos sedutores, ela é inútil (constitui um custo desnecessário ao Estado).

A aplicação de penas a esses eventos seria inútil, pois dois males se somariam, a saber: o mal da ofensa ao mal da punição, não havendo nenhum proveito na aplicação da pena ${ }^{429}$.

Mais uma vez torna-se interessante ressaltar que o que está por trás do fato de se determinada ofensa deve ou não tornar-se matéria da legislação é um cálculo de custo benefício, um balanço entre prazer e dor, conforme a racionalidade calculadora, conforme o princípio de utilidade que enuncia que é correto buscar o prazer e errôneo fugir da dor. Ou seja, em todos os casos, aquilo que está conduzindo a solução, aquilo que está apontando para a linha divisória entre as normas que devem pertencer à legislação ou à ética é um apelo ao primeiro princípio moral condizente com a natureza do indivíduo teórico de Bentham.

\footnotetext{
${ }^{429}$ Bentham, 1789, em An Introduction to the Principles of Moral and Legislation p. 146.
} 
Em alguns casos a punição é considerada não proveitosa ou não lucrativa em virtude de um inocente ser envolvido. Isto pode ocorrer devido à dificuldade de se fixar a quem a culpa é devida. Este problema pode decorrer devido a dois fatores: o primeiro diz respeito à própria natureza da ação e o segundo concerne à qualidade dos homens colocados no governo, ou seja, diz respeito às capacidades que os homens possuem de imputar a culpa. No que concerne à última dificuldade, pode-se depreender que as capacidades dos homens do governo serão proporcionalmente limitadas à sua capacidade de lidar com a linguagem. Isto quer dizer, em outras palavras, que os atos de difícil imputação de culpa são difíceis de serem levados para o âmbito da legislação, sem uma complicação verbal ou uma situação que dê margem a interpretações errôneas da $1 \mathrm{ei}^{430}$.

Considerando o exposto, em quase todas as variantes do caso em que a punição não é proveitosa (com exceção do conjunto de indivíduos que podem cometer um crime devido ao conjunto de indivíduos criminosos, conjunto b, citado), a ética, compreendida como conjunto de regras de ação capaz de zelar pela felicidade da comunidade deve ser aplicado. Em outras palavras, uma negação dos tipos de atos acima descritos (ofensas) deve ser desestimulada por meio das regras da ética. Seja a partir do estímulo de motivos sociais ou a partir da força da sanção moral (funciona como se um ou mais membros da comunidade possuíssem destaque e tivessem poder para reprimir atos perniciosos), fazendo como que os membros de uma sociedade levem em conta o bem estar geral dela, como sendo de seu próprio interesse.

Em outras palavras, o princípio de utilidade, a racionalidade calculadora, o cálculo entre prazer e dor, o apelo ao primeiro princípio moral de Bentham aponta para que a ética seja aplicada nos casos da interação negativa entre indivíduos, apenas quando não for benéfico formular regras a partir da legislação. Ou seja, é o princípio de utilidade, através de um balanço de prazer e dor, ou custo benefício, que delimita a fronteira entre a ética e a legislação neste campo (relativo à probidade), no sistema de Bentham.

Desta forma, após a apreciação dos casos em que não cabe punir, mas apenas aplicar a ética, volta-se a apresentar os outros tipos de ações, a saber: ações que

\footnotetext{
${ }^{430}$ Conforme mencionado ao longo deste trabalho, Bentham insiste que os legisladores ou homens públicos tomem muito cuidado com a linguagem, pois esta constitui um importante instrumento através do qual muita dor pode ser gerada, quando mal aplicada.
} 
não envolvem interações e ações que envolvem interações positivas entre os indivíduos. Tais ações são relembradas para que se delimite (sempre com um apelo ao primeiro princípio) o espaço da ética no sistema de Bentham. Este espaço passa, contudo, pelos limites entre a ética e a legislação (quais regras ficarão no escopo da legislação e quais regras ficarão no escopo da ética).

Conforme mencionado, os tipos de ações possíveis entre os indivíduos são: a) ação de um indivíduo para consigo (denominada prudência quando ocasiona mais prazer do que dor), b) ação de um indivíduo para com os outros de maneira positiva (chamada beneficência ou benquerença quando gera mais prazer do que dor) e c) interação entre indivíduos de forma negativa ou abstenção de geração de dor para outros (probidade quando ocasiona mais prazer do que dor).

Tem-se mostrado que o grau em que a ética privada possui necessidade de intervenção da legislação é diferente no que concerne aos três tipos de ações, devido a um cálculo de prazer e dor (custo benefício) das conseqüências de se colocar o aparato legislativo em funcionamento. A questão toda, de se criar uma norma legal, de transportar uma norma moral para uma norma legal é sempre um apelo ao princípio de utilidade, um apelo ao primeiro princípio, uma questão de cálculo, de custo benefício, não há princípios intermediários ou princípios secundários para intermediar o espaço da ética, sem que se faça um apelo, a todo instante ao princípio primeiro, diferentemnte de como ocorre para Mill.

As regras da prudência ou aquelas que não envolvem interação entre indivíduos são as que menos necessitam de auxílio da legislação. Bentham diz que só pode ser por um defeito do entendimento que um indivíduo se descuidará das regras de prudência consigo. Caso o agente cometa estes erros, isto será devido, apenas, a ele e ninguém mais deve ser envolvido nisto. Ainda no que diz respeito a este assunto, o autor ressalta que alguns poderiam objetar que os homens conhecem pouco sobre si e por isso necessitariam de ajuda. A resposta de Bentham, a esta argumentação, ressalta que ninguém conhece mais sobre si do que o próprio indivíduo, em outros termos, os legisladores não possuem meios para saber mais sobre os interesses dos agentes do que eles próprios, no que diz respeito aos cuidados individuais tomados por eles (regras da prudência). 
De acordo com Bentham, é apenas com respeito às amplas linhas de conduta, referentes a interações negativas entre indivíduos, nas quais todas as pessoas ou ao menos alguns indivíduos encontram-se envolvidos que o Estado pode ter a pretensão de interferir ${ }^{431}$. Mesmo assim, em muitas dessas ocasiões, a interferência da legislação não é recomendada, conforme mostrado acima. Em muitos momentos o Estado não deve esperar submissão à sua simples força de sanção, pois o princípio de utilidade, o cálculo entre custo benefício aponta para a não intervenção do Estado. Em outras situações, tudo o que ele tem a fazer é aumentar a eficácia da ética privada dando força e direção à sanção moral, que, obviamente, esteja de acordo com a felicidade da maioria ${ }^{432}$. Bentham questiona: com qual chance de sucesso poderia o governo abolir o alcoolismo através do uso da punição legal? $\mathrm{O}$ autor expõe que nem todas as torturas que a engenhosidade humana pudesse criar seriam capazes de impedir este vício ${ }^{433}$. Uma massa muito superior de males seria gerada antes que qualquer progresso fosse feito.

A dificuldade em realizar este tipo de punição reside no fato de tentar obter evidência para esta ofensa sem espalhar desânimo nos vínculos de simpatia pelas famílias, removendo a influência dos motivos sociais em qualquer comunidade.

Segundo Bentham, tudo que os homens do governo podem fazer contra ofensas referentes à falta de prudência com algum êxito é sujeitar os agentes que cometem estes atos a uma fina censura, para mantê-los com uma certa sombra de má reputação.

Contudo, de acordo com Bentham, em sua época, os legisladores tinham o hábito de interferir o máximo que podiam neste ramo do dever (a prudência) ${ }^{434}$. O grande desafio seria, então, persuadir os governantes a ficarem limitados a um raio de ação em que a lei é eficiente ${ }^{435}$, para que a liberdade do sujeito não fosse limitada por paixões e preconceitos, imprimindo custos à sociedade, muito superiores ao benefício que podem ser auferidos. Note-se, mais uma vez, que a área da prudência fica restrita ao campo da

\footnotetext{
${ }^{431}$ Bentham, 1789, em An Introduction to the Principles of Moral and Legislation p. 146.

432 Ibid.

${ }^{433}$ Bentham, 1789, em An Introduction to the Principles of Moral and Legislation p. 147.

${ }^{434}$ Bentham, 1789, em An Introduction to the Principles of Moral and Legislation p. 147: "[...] It may be observed, that with regard to this branch of duty, legislators have, in general, been disposed to carry their interference full as far as is expedient. The great difficulty here is, to persuade them to confine themselves within bounds [...]".

${ }^{435}$ Bentham, 1789, em Uma Introdução aos Princípios da Moral e da Legislação pp. 72-73.
} 
ética, uma vez que os custos de transformar estas normas em normas da lei é muito alto, portanto, mais uma vez é o princípio de utilidade (que ressalta que é correto buscar o prazer e correto fugir da dor), é um apelo ao primeiro princípio que está norteando a delimitação do espaço da ética.

$\mathrm{O}$ autor comenta que é muito comum que se cometam graves erros em prol da religião, com interferência direta na vida das pessoas, quando interações não são praticadas (no que concerne à prudência). Uma analogia é feita, pelo autor, com a classe de legisladores. Bentham argumenta ${ }^{436}$ que os homens do governo empurram seu povo para o abismo quando tentam legislar sobre os assuntos privados dos indivíduos, sobre as regras da prudência.

Conforme discutido acima, as regras da probidade (integridade de caráter) são aquelas que mais necessitam de assistência do legislador. Na maioria dos casos em que alguém cause mal a outrem a lei deve interferir, enquanto que são poucos os casos em que a legislação deve estar presente quando alguém tenta ferir a si próprio. Mais uma vez, a decisão de aplicar a legislação ou não a estes casos é um apelo direto ao princípio de utilidade, à razão calculadora do indivíduo, derivada da natureza humana do agente teórico de Bentham.

No que concerne a todas as normas das quais se vem tratando, a respeito do sistema de Bentham, é possível concluir que a ética privada depende da existência da legislação, para este autor, pois primeiramente o legislador deve estabelecer quais coisas dirão respeito à propriedade do homem, antes que as regras gerais da ética tenham alguma aplicação. De acordo com Bentham, é necessário que se saibam quais são os ditames da legislação para que depois as regras da ética sejam, então, aplicadas ao campo da probidade. Mesmo nos casos em que não cabe punir, vistos acima, seria necessário um exame do legislador, baseado em um balanço de custo benefício das aplicações de normas da legislação, para que estes fossem assim nomeados e pudessem ser deixados sob o escopo da ética (como quando a punição é não proveitosa).

Assim, no que concerne à probidade, pode-se dizer que a legislação engloba a ética privada, no sentido que dá espaço para ela existir quando não compensa ser

\footnotetext{
${ }^{436}$ Bentham, 1789, em An Introduction to the Principles of Moral and Legislation p. 147.
} 
aplicada, quando o balanço entre custo benefício guiado pelo princípio de utilidade aponta para a não interferência da legislação.

De todas as afirmações aqui formuladas depreende-se que, o princípio de utilidade está na base da criação fictícia da legislação e a partir de vários casos em que a legislação não pode existir, devido aos ditames da utilidade, há espaço para a aplicação da ética, através da sanção moral, nos casos de ofensas.

Em outros termos, o princípio da utilidade, explicitado como o grande princípio da moral, como aquele princípio que decide, através de um cálculo entre prazer e dor quais normas ficarão restritas à moral e quais normas serão convertidas à legislação, no que diz respeito à interação negativa entre indivíduos (probidade quando gera mais prazer do que dor), é aplicado para a construção de uma legislação que apenas deixará espaço para ética quando os custos punição concorrerem com os prejuízos das ofensas, sem que benefícios maiores do que ambos os custos somados sejam auferidos (principalmente nos casos em que a punição é dita não proveitosa).

As regras de beneficência, diferentemente das regras de probidade, devem ser deixadas sob escopo da ética privada, também por uma questão de eficiência (de apelo ao princípio de utilidade). Isto deve ser feito desta forma, uma vez que a qualidade benéfica dos atos dependerá, principalmente, da disposição voluntária do agente que o faz gerar bem, isto é: sob o efeito de quais motivos o indivíduo encontra-se inclinado a agir, como no caso de motivos sociais como simpatia, amor à amizade ou amor à reputação.

As ações de benevolência são aquelas efetuadas de acordo com a livre vontade do indivíduo, não constrangido pelo governo. No entanto, o autor ressalta que a legislação pode abarcar esta área quando os indivíduos podem salvar alguém sem que haja risco para ele mesmo. Em outras palavras, os agentes deveriam estar moralmente e legalmente obrigados a salvar outros caso a situação não oferecesse risco a ele mesmo. Mais uma vez a situação é resolvida por um balanço entre prazer e dor ou custo de benefício do risco que a situação oferece e um apelo ao primeiro princípio é efetuado.

De todo o exposto, conclui-se que a ética privada ensina como cada homem persegue sua própria felicidade, pelos motivos que oferecem a si mesmos, afetando ou não outros indivíduos. No caso de afetar outros indivíduos, pode-se dizer que a ética atuará ou não com o auxílio da legislação, dependendo daquilo que o princípio da 
utilidade prescreve, em cada situação, conforme o balanço entre prazer e dor apontar para a interferência ou não da legislação. Nos casos em que o princípio da utilidade admite sua interferência, a arte da legislação ensina como um grande número de homens, compondo uma comunidade, pode estar disposto a perseguir o curso da felicidade de todos, por meio de motivos a serem aplicados pelo legislador.

Desta forma, o espaço da ética ou o campo do agir moral estará restrito, pela aplicação do próprio princípio de utilidade (balanço de prazer e dor) às ações de indivíduos que não envolvem interações (prudência), às ações com o outro que proporcionam prazer (beneficência) e às ações que salvaguardam a felicidade dos indivíduos (probidade) nos casos em que o balanço de prazer e dor aponta a não intervenção da lei ou a não punição.

Em outras palavras, parece haver bastante interferência para a ética no sistema de Bentham, pois a legislação não interfere em todos estes casos acima mencionados, contudo, a ética de Bentham, conforme tem-se mencionado, é composta de um único princípio, a saber: o princípio de utilidade. É ele que dita se determinadas normas serão transformadas em normas da legislação ou não, é ele que dita se determinadas normas permanecerão sob o escopo da ética.

Entretanto, mesmo as normas que permanecerão sob o escopo da ética, como normas de prudência, os cuidados que os indivíduos têm com si mesmo (como o apreciar a arte, por exemplo, estudar, etc), o fazer o bem ao outro (ser simpático, sempre que puder ajudar o próximo), e o não fazer o mal ao outro (não matar, não roubar), que podem ser consideradas como normas do costume, serão sempre revisadas a cada circunstância através de um cálculo racional guiadas pelo princípio de utilidade, ancorado na simples natureza do indivíduo teórico de Bentham sujeita à ontologia do prazer e da dor. Conforme foi colocado no início deste capítulo, o bem moral é dito existir de acordo com a ontologia do autor, conforme seja gerado um bem físico, mesmo os vícios e virtudes são ditos existir conforme gerem um bem físico. Desta forma, as regras do costume acima elencadas, serão revisadas a cada ação de acordo com um cálculo racional, transformando o indivíduo teórico de Bentham em uma espécie de robô dos cálculos, não admitindo segundos princípios para a ação, tão caros a John Stuart Mill. 
A partir do que foi explicitado, é possível concluir que não há diferença de natureza do conteúdo das regras que constam na ética e na legislação. É a análise de custo-benefício (prazer e dor) que separa os raios de ação de uma e de outra, sem que critérios adicionais ao princípio de utilidade precisem ser criados pelo autor, para que os limites entre a ética e a legislação sejam estabelecidos.

Além disso, é possível afirmar que a moralidade de Bentham é negativa no sentido de que o seu indivíduo revisa a toda ação as regras do costume postas a ele. Portanto, sua moral, é composta, basicamente, de um princípio, qual seja: o princípio de utilidade, que separou as normas da ética da legislação, que demonstrou que ambas não possuem diferença de natureza e que derruba todas as regras dos costumes ou quaisquer princípios secundários a cada ação, caso o balanço entre prazer e dor pesar para a dor. Isto tudo é derivado da natureza do indivíduo teórico de Bentham que derivou o modelo de indivíduo teórico de Bentham, que derivou o princípio de utilidade e o elaborado método de efetuar cálculos deste indivíduo.

Será possível verificar a seguir que a mais complexa natureza do indivíduo teórico de Mill derivará um princípio de utilidade mais complexo, que permitirá a elaboração de princípios secundários que inclusive são mais fáceis dos sentimentos humanos darem assentimento a eles quando se trata do campo da prática. Estes princípios secundários derivarão ou serão as próprias regras morais. Em outras palavras, a natureza mais complexa do indivíduo conceitual de Mill, conforme explanado por este autor, é uma natureza mais próxima daquilo que o homem de fato é e por isso deriva um princípio de utilidade que apesar de assumir que a única finalidade dos homens é a felicidade, reconhece que muito mais coisas precisam ser explicitadas para que a felicidade seja conquistada. Neste ponto insere-se a moralidade. Para Mill, não é necessário que um constante apelo ao princípio primeiro precise ser feito como para Bentham Assim como sua natureza humana é mais próxima do homem como ele de fato é (e isto é conseguido por seu método dedutivo concreto da física, por composição de causas e não pelo método geométrico utilizado por Bentham), seu princípio de utilidade irá recomendar que muitas outras coisas sejam aventadas para que se entenda a noção de prazer. O homem de Mill não vai para o mundo prático munido de apenas o princípio de utilidade, ele possui princípios secundários de ação que são regras morais pré-estabelecidas, decisões que 
foram tomadas no passado sobre quais ações tomar sob determinadas circunstâncias (é claro que assumindo que Mill é um utilitarista, essas decisões sobre estes princípios secundários foram tomadas com base no fato de que o princípio de utilidade recomenda a maximização da felicidade).

4. A Ética de Mill e uma comparação com a Ética e o indivíduo teórico de Bentham

Tendo isto em vista a Ética do o sistema de Bentham, relembra-se que no capítulo segundo foi feita uma breve descrição tanto dos autores que influenciaram Mill quanto de alguns elementos de sua vida para que ele se tornasse um utilitarista de tipo mais complexo, para que se entendesse o motivo pelo qual o homem de Mill seria constituído por uma natureza mais complexa. A breve leitura genética psicologista feita de sua vida justificou-se, pois o próprio autor relacionou sua vida à sua obra no livro Autobiografia e porque o próprio autor pode ser considerado um autor psicologista ao considerar que um dos componentes da natureza humana (os mais abstratos, pelos quais passam as leis menos abstratas; leis empíricas) constitui as leis da mente, como as leis de associação, lei esta que pode ser aplicada à própria análise da vida de Mill, dado que Mill é uma pessoa dotada de uma natureza humana. Em outras palavras, ao ser exposto a esta rígida educação intelectual seria impossível que não gerasse impressões e por fim suas próprias idéias associadas às leituras. Realizando a breve leitura genética da vida de Mill, a partir da análise do livro Autobiografia, pôde-se concluir que este autor recebeu uma vasta influência bibliográfica, especialmente de livros de história, de filosofia e de livros científicos (como o Sistema de Química do Dr.Thomson). Essas influências marcaram seu pensamento, algumas mais do que outras. Como pontos de inflexão em seu pensamento foram citados autores antigos como Aristóteles; Mill ressalta que a Retórica teria sido o primeiro tratado sobre moral ao qual havia sido exposto. Outros autores antigos como Epicuro e Platão também tiveram influência marcada, segundo ressaltado na Autobiografia. Dos livros de História, Mill agradecia a seu pai por ter colocado em suas mãos além do relato de história antiga, romana e moderna, leituras sobre homens enérgicos, exemplos a serem seguidos, daí a explicação de Mill sempre expor suas idéias a debates, como na Debating Society ou na Edinburgh Review. Mill havia lido alguma 
poesia antes de sua crise mental, como a Ilíada, a Odisséia, poesias de Campbell, de Dryden e Cowper, mas ressalta que o poema que mais tocou seus sentimentos foi o poema Gertrude de Wyoming. Sobre lógica o autor havia lido o Organon de Aristóteles até os Analíticos, bem como o Computatio Sive Lógica de Hobbes. Além de ter uma sólida formação empirista advinda de Condillac ( $O$ Tratado das Sensações), o autor leu escritores britânicos de filosofia da mente advindos de Berkeley, Hume (de onde, sem dúvida extraiu as leis da mente do indivíduo como a lei de associação de idéias de Hume das Investigações sobre o Entendimento Humano que enuncia que: "Quanto a mim, creio existirem apenas três princípios de conexão entre as idéias, a saber: a semelhança, a contiguidade de tempo ou lugar, e a causa e efeito") [Hume, 1974, p. 137.], Reid, Dugald Stewart ${ }^{437}$ e Brown. Contudo, antes da crise mental de Mill, o autor que constituiu um referencial que uniu todas as suas idéias e que parece ter colocado metas até então inatingíveis socialmente através de seu princípio de utilidade foi Jeremy Bentham com seu utilitarismo, especialmente no que concerne ao âmbito moral, escopo deste trabalho. Este foi o grande ponto de inflexão de tudo que Mill havia lido antes de sua crise mental. É relato da Autobiografia que seu pai, figura fundamental em sua vida servia mais de educador intelectual, do que de fonte de afeto paterno e isto, de acordo com o relato que o autor faz em seu livro, parece ter influenciado negativamente o desenvolvimento de seus sentimentos. Conforme afirma o autor, uma mente analítica havia sido formada antes que outros sentimentos (lembrando que não há diferença entre estados da mente e sentimentos) ou hábitos houvessem sido cultivados no autor: o hábito de análise tem uma tendência a corroer os sentimentos quando não se cultiva outro hábito mental [Mill, 1873, p. 127].

Após o contato com a filosofia de Bentham (através da leitura do Traité de Legislation como havia sido apresentado ao continente) e a união de todas as suas idéias através da filosofia utilitarista, após a empolgação que havia sentido através das conclusões que passou a enxergar com a aplicação da filosofia de Bentham, Mill relata que aquele momento se esvaeceu como um sonho e o autor passou a sentir a vida como um peso que não passava nem com uma noite de sono (soberano remédio para os

\footnotetext{
${ }^{437}$ Dugald Stewart afirma que todos os primeiros princípios das ciências pertencem à mente humana. John Mill será amplamente influenciado por Dugald Stewart, pois como está explícito no quarto parágrafo de seu texto On the Definition of Political Economy, Mill reafirma a afirmação de Stewart.
} 
pequenos males da vida), nem tão pouco com a imaginação de que todas as suas metas (que coincidiam com metas sociais) seriam cumpridas.

Mill viu-se, então, diante de uma crise mental que não o impedia de realizar suas tarefas corriqueiras, mas que tornava, de acordo com sua descrição, o mundo pesado. É tese deste trabalho que tal experiência de vida ${ }^{438}$ foi fundamental para que o autor repensasse e reelaborasse o utilitarismo de Bentham, caso contrário, caso não tivesse vivenciado o que vivenciou teria, provavelmente, adotado o utilitarismo de Bentham sem alterações.

Enfim, em meio à sua crise mental o autor percebeu que a busca da felicidade não era algo tão simples como um cálculo entre prazer e dor, conforme ressaltara Bentham. Em meio à sua crise, Mill percebera que o ser humano era algo bem mais complexo do que estar sujeito à elaboração de cálculos entre prazer e dor, o autor entendera que a felicidade possuía diversos e variados componentes e que tais componentes seriam resultados da composição de inúmeras causas que explicavam o caráter dos indivíduos. Não poderia ser apenas por um princípio (o princípio de utilidade) que o homem estaria reduzido e explicado e que nada mais precisaria ser dito à cerca da moralidade derivada deste homem dotado de uma razão calculadora.

Para sair de sua crise mental Mill buscou auxílio na poesia, não em qualquer poesia, mas na poesia romântica de Wordsworth que despertasse a contemplação serena que gerasse prazeres de qualidade superior e não em dores que agravassem seu estado, como foi o caso da leitura de Byron. Contudo, a primeira vez, durante sua crise mental, que ocorreu o despertar de seu phatos, que fez com que ele sentisse que estava vivo, que ainda era capaz de possuir sentimentos intensos ${ }^{439}$, foi quando ocorreu de comover-se com a leitura das Memórias de Marmotel, a passagem que havia comovido Mill referia-se ao fato da morte de um pai e o filho passaria, então, a constituir tudo para a família. A vívida representação da cena comoveu o autor, até levá-lo ao choro.

Além da leitura, Mill entregou-se à apreciação da música, à apreciação de Mozart e especialmente de Weber de sua ópera Oberon, conforme descreve. A partir do estímulo de seus sentimentos mais elevados, ou de seus prazeres mais elevados, a partir

\footnotetext{
${ }^{438}$ Capaldi, 1984.

${ }^{439}$ Lembrando que os sentimentos, para Mill, são estados mentais.
} 
do equilíbrio de suas faculdades, Mill foi, gradativamente, saindo de sua crise mental e convencendo-se que o indivíduo não era apenas um indivíduo frio, dotado apenas de uma razão calculadora e que essa razão calculadora seria o principal componente na busca da felicidade, como ocorre para o indivíduo teórico de Bentham. O indivíduo teórico de Mill seria, conforme ele verificava a partir de suas leituras e mesmo a partir de sua experiência de vida (fato que depois será corroborado pelo seu método dedutivo concreto da física) mais complexo do que o de Bentham, apesar de ainda buscar a felicidade, ele não buscaria um prazer sem qualquer qualificação, porque um prazer sem qualificação não satisfaz as concepções humanas de vida. Este indivíduo com uma natureza mais complexa, relativamente à natureza do indivíduo teórico de Bentham, conforme Mill iria desvendando, após sua crise mental, busca o prazer e foge da dor, isto é; busca a felicidade, mas nesta busca da felicidade ele se lança no mundo, no campo prático da ação com regras ou princípios secundários (não apenas dotado do princípio da utilidadeprincípio primeiro) que o tornam um agente moral. Neste momento de sua vida, Mill estaria percebendo que para preencher uma concepção humana de vida, a apreciação da arte era fundamental como componente da felicidade, uma vez que esta era capaz de tocar seus sentimentos, segundo afirma.

\footnotetext{
"A manutenção de um equilíbrio entre as faculdades pareciame agora de primeira importância. O cultivo dos sentimentos se converteu em um dos pontos primordiais de meu credo ético e filosófico”. [Mill, 1873, p. 131]
}

Coleridge, poeta e filósofo inglês, também foi fundamental para que Mill vislumbrasse a compreensão de seu estado mental e conseqüentemente a saída desse estado. Conforme cita-se um trecho de seus poemas a seguir [Mill,1873, p. 124]:

\footnotetext{
"A grief without a pang, void, dark and drear, A drowsy, stifled, unimpassioned grief, Which finds no natural outlet or relief In word, or sigh, or tear., 440
}

${ }^{440}$ Coleridge, "Work without Hope," in Poetical Works, 3 vols. (London: Pickering, 1828), Vol. II, p. 81. "Uma grande tristeza sem uma emoção aguda, inaceitável,escura, sem interesse, Um impassível, irrespirável, desapaixonado sentimento. 
Mill não apenas saía de sua crise mental com o auxílio das artes, especialmente a poesia e música, que o faziam perceber que o cultivo de prazeres elevados era parte fundamental da natureza humana, como expunha suas novas idéias na Debating Society ressaltando os méritos que havia na leitura da poesia de Wordsworth. O autor ressaltava que não agüentaria aquela dor por mais de um ano e parece que passado um ano, a o peso que sentia havia se extirpado. Contudo, tanto Mill, quanto suas idéias haviam se alterado, como pode ser confirmado na passagem seguinte.

"Descobri que o edifício de minhas velhas opiniões recebidas estava cedendo em muitos pontos, mas nunca deixei que ele se desfizesse em pedaços, ocupando-me incessantemente em reconstruí-lo com novos materiais" [Mill, 1873, p.141]

No que diz respeito à formação do método das ciências morais, Mill revisou o método da física (dinâmica) e química (através do Sistema de Química do Dr. Thomson). Mill encontrou na composição de forças o mais completo exemplo do processo lógico aplicável às ciências sociais. Ele investigou que quando a mente aplica o método da composição de forças, ela efetua um simples método de adição, em outras palavras, a mente adiciona uma força (no caso causa de um fenômeno social) à outra e coloca o efeito resultante das forças desses efeitos separados. Mill estava convencido que o método físico de composição de causas (abrangendo várias causas do fenômeno social) era o método correto a ser adotado em ciências sociais, por constituir uma boa explicação do complexo fenômeno social.

Além disso, foi ainda explicitado, no capítulo segundo, que após sua crise mental, Mill foi amplamente influenciado pela filosofia continental, especialmente pelos sansimonianos. Dentre eles um sansimoniano que lhe chamou bastante atenção foi Auguste Comte. Este autor parecia a Mill superior aos demais por colocar ênfase em certa progressão da história, mas para que a história pudesse progredir seria necessário 
que o indivíduo também pudesse progredir. Em outras palavras, tem-se assumido neste trabalho um modelo dinâmico de indivíduo, que o indivíduo tem a capacidade de se transformar ao longo do tempo e esta é uma característica advinda, especialmente dos escritos de Comte. De acordo com este autor, a história passa por períodos orgânicos que seriam períodos em que as pessoas possuem suas crenças firmes e períodos críticos em que a humanidade questiona suas crenças, sem ainda colocar nenhuma crença no lugar.

Ademais, Mill, a partir da leitura de escritos de psicologia analítica de Berkeley, Hume, Reid, Dugald Stewart, Brown e do livro de seu pai James Mill, Análise da Mente, formou sua concepção do indivíduo acerca das leis lógicas, leis da mente do indivíduo, denominadas: a) toda impressão mental tem sua idéia, b) as leis de associação e c) freqüência de conjunção. A primeira dessas leis enuncia que não importa qual seja a causa que tenha gerado um determinado estado de consciência, um outro estado de consciência de menor intensidade é passível de ser produzido nos seres humanos (que constitui, precisamente a idéia da impressão). A segunda lei mental, denominada lei de associação se divide em duas leis, a saber: a primeira lei enuncia que idéias similares tendem a se provocar umas às outras, a segunda enuncia que quando duas impressões foram experimentadas simultaneamente ou em sucessão imediata então sempre que a idéia de uma retorna, a idéia da outra tende a ser provocada. A terceira lei enuncia que a maior intensidade em uma ou nas duas impressões é equivalente para torná-las a se provocar umas às outras a uma maior freqüência de conjunção. Vale lembrar que estas leis mentais, apesar de possuírem o auxílio das leituras de psicologia analítica de Mill e uma percepção melhor da constituição humana após sua crise mental, são provadas a partir de seu método indutivo. Assim como os outros componentes do modelo de indivíduo que estão sendo aqui traçados, são formulados a partir das leituras de Mill (da história da filosofia), bem como a partir de sua mais ampla compreensão pós-crise mental de que a natureza humana do indivíduo não poderia ser reduzida a uma racionalidade calculadora. Contudo, todos estes componentes do modelo de indivíduo teórico de Mill poderão ser também provados a partir do método de Mill de formular ciências sociais (que constitui o método dedutivo-indutivo concreto da física, por composição de causas, ou dedutivo inverso). 
O último elemento, componente da natureza humana que Mill percebeu como um elemento fundamental, derivado da própria análise que fez de si mesmo, foi o hábito, que as ações são guiadas por hábito, que os seres humanos cultivam hábitos, como quando comenta que o hábito da análise quando cultivado separado do todo e qualquer outro hábito mental tinha a tendência de corroer os sentimentos, conforme o próprio autor afirma: "o hábito de análise tem uma tendência a corroer os sentimentos quando não se cultiva outro hábito mental" [Mill, 1873, p.127]. Inúmeras passagens corroboram o fato de que o indivíduo age por hábito, como é o caso de [Mill, 1861, p. 240], [Mill, 1838, p. 168], [Milll, (1863), 1999, p. 104] e quando diz marcadamente no utilitarismo que: A vontade é filha do desejo, e abandona a tutela de seus pais apenas para se alojar ao hábito [...]” [Mill, 1861, p. 240] e diversas outras passagens. Pensa-se que a afirmação de que as ações são guiadas por hábito tem origem em seus estudos antigos, embora esta afirmação não seja tese deste trabalho, dado que isto precisaria ser provado, com uma pesquisa e comparação às obras dos antigos com as obras de Mill.

Na primeira citação do parágrafo acima, para ilustrar que os indivíduos agem por hábito, comentou-se uma crítica à análise (à operação de encontrar defeitos em uma argumentação, de acordo com a lei de causalidade, silogismo, etc) que Mill efetuou por ter uma tendência a corroer os sentimentos quando não é cultivada em conjunto com outros hábitos mentais, como o afeto às pessoas (simpatia), o gosto pela arte, etc. De fato, Mill criticou a formação de uma mente analítica quando esta não fosse cultivada em conjunto com outras características da natureza humana, mas nunca deixou de apreciar seu valor, segundo o próprio autor afirma:

[...] pois devemos à análise o conhecimento mais seguro que possuímos a respeito das seqüências permanentes da natureza, das conexões reais entre as coisas, que independem de nossa vontade e de nossos sentimentos, e das leis naturais em virtude das quais uma coisa é, em muitos casos, de fato inseparável de outra [...]. [MILL, 1873,p.127].

Desta forma, após sua crise mental, Mill havia, intuitivamente, formando as bases para a construção de um novo modelo de indivíduo. Pois, apesar de não ter rejeitado, totalmente, a teoria de Bentham, a saber: que as pessoas buscam a felicidade e 
evitam a infelicidade (ou em outras palavras buscam o prazer e fogem da dor) e é tese deste trabalho que a tese hedonista se sustenta no utilitarismo de Mill, caso contrário ele não seria um utilitarista, o autor estava convencido que muitos outros elementos deveriam ser adicionados à natureza humana. Na Atutobiografia é possível verificar que um elemento crucial da existência humana constituirá o cultivo ao intelecto e será este mesmo cultivo ao intelecto que distinguirá a existência humana de uma existência animal, após a análise do livro Utilitarismo resta claro que as faculdades mais elevadas ${ }^{441}$ elencadas pelo autor que satisfazem prazeres mais elevados e, portanto, concepções de vida mais elevadas, suprem esse valor que Mill passa a dar a essa vida verdadeiramente humana (ligada ao cultivo intelectual, artístico). Além desta característica da natureza humana do indivíduo teórico de Mill, que sem dúvida está subordinada à tese hedonista, pois é um dos componentes da felicidade, a capacidade que o indivíduo tem de se transformar ao longo do tempo, será um constituinte fundamental da natureza humana, uma vez que se assume que a sociedade é composta por indivíduos e que a teoria da história de Mill é composta, assim como foi derivado de Comte, de períodos estáticos (quando as pessoas mantêm suas crenças e convicções- é o período orgânico de Comte) e períodos dinâmicos (quando as pessoas questionam as crenças passadas e por fim estabelecem novas crenças para então saltar para outros períodos estáticos). Contudo, conforme foi argumentado, é necessário que o indivíduo também seja capaz de se transformar ao longo do tempo, se há uma teoria da história como esta, para Mill. Assume-se e é tese deste trabalho que o modelo de indivíduo teórico de Mill é dinâmico.

Um fato que teria atormentado Mill quanto à questão do indivíduo talvez não poder modificar seu caráter, dizia respeito à doutrina da necessidade. $\mathrm{O}$ autor aceita essa doutrina no sentido de que é possível conhecer (se for possível) as causas que compõem o caráter de um indivíduo e, nesse caso, é possível prever suas ações. Contudo, isto não é um determinismo, uma vez que algumas circunstâncias são determinadas pelos arranjos sociais e outras estão na posse do próprio indivíduo controlar, como por

\footnotetext{
${ }^{441}$ Mill, 1861, p. 190. "É fato inquestionável que os igualmente familiarizados com ambos os prazeres e igualmente capazes de apreciar e desfrutar um e outro preferem de maneira mais acentuada o que dá vida a suas faculdades mais elevadas. Poucos seres humanos consentiriam em se transmutar em algum dos animais inferiores sob a promessa de gozar plenamente os prazeres animalescos; nenhum ser humano gostaria de ser um tolo, nenhuma pessoa instruída gostaria de ser um néscio”.
} 
exemplo, realizar certas escolhas e desta forma o indivíduo tem o poder, também de, em parte, influenciar sua transformação ao longo do tempo.

Além da tese hedonista, das faculdades mais elevadas, da capacidade que o indivíduo tem de se transformar ao longo do tempo seja através de suas próprias escolhas, seja através de melhorias institucionais que podem ocasionar circunstâncias favoráveis ao desenvolvimento de seu caráter, o fato de que o indivíduo pode, por natureza, agir por hábito também parece ser uma constante nas obras de Mill. Além disso, conforme adiantou-se, a natureza humana seria composta por leis lógicas: a) toda impressão mental tem sua idéia, b) as leis de associação e c) freqüência de conjunção. Mill, entretanto, com certeza, teve influência de autores que escreveram sobre psicologia analítica como Berkeley, Hume, Reid, Dugald Stewart, Brown, mas tais leis podem, perfeitamente, serem provadas, pelo seu método indutivo.

Assim, o modelo de indivíduo, a natureza humana que se tem argumentado do agente teórico de Mill, e que faz parte da tese deste trabalho, é composta das leis da mente, como a lei de associação, a tese hedonista que reside no fato do indivíduo ter a capacidade de sentir e buscar o prazer e fugir da dor, e subteses da tese hedonista, subteses porque são características da natureza humana associadas à busca do prazer como as faculdades mais elevadas que derivam prazeres de qualidade mais elevada, a capacidade que o indivíduo tem se de transformar ao longo do tempo e o agir por hábito que gera constância às ações escolhidas pelos agentes. Neste ponto, no que diz respeito ao agir por hábito poder-se-ia argumentar que os indivíduos podem ter hábitos viciosos, mas muitos agentes continuam a praticar tais ações, ainda que gerem dor a longo prazo e prazer a curto prazo, por uma dificuldade de reeducar seus hábitos, daí não se segue que o hábito não seja uma característica humana capaz de dar constância a ações que associam prazer a longo prazo.

Esse modelo de indivíduo que pôde ser extraído intuitivamente após a crise mental de Mill, mas ainda com o auxílio de outros livros como o Utilitarismo para que se entenda a tese hedonista, o que são as faculdades mais elevadas e para que se compreenda que o indivíduo age por hábito. Com o auxílio do livro VI do Sistema de Lógica foram entendidas as leis lógicas do indivíduo e que ele pode transformar-se ao longo do tempo. 
Contudo, todos esses elementos podem ser provados, a partir do método construído por Mill, conforme ficou demonstrado no capítulo terceiro.

O método utilizado para a construção e prova do modelo de indivíduo ou para a construção da natureza humana do homem de Mill é o método indutivo para a elaboração das leis mais altas como as leis da mente, segundo foi mencionado estas leis são: a) toda impressão mental tem sua idéia, b) as leis de associação e c) freqüência de conjunção. Para a construção das outras características do indivíduo teórico de Mill o método utilizado foi o dedutivo inverso, uma vez que é uma lei empírica o fato de que a finalidade e única finalidade na vida dos homens é a busca da felicidade (buscar o prazer e evitar a dor), todos os outros fins são desejáveis em função desta finalidade e é esta lei empírica obtida por observação que é remetida às leis mais altas (leis da mente) por indução, como à lei de associação, então, segundo argumentou-se, tendo em vista a lei de associação, ao realizar-se uma ação A pode ser gerado um prazer B e à idéia da ação A e do prazer B associa-se à noção de agradável, sucessivamente, ao ser realizada uma ação C um prazer D é gerado, a noção de agradável é gerada novamente e assim sucessivamente, tem-se que às idéias das ações $\mathrm{A}$ e $\mathrm{C}$, idéias de prazeres $\mathrm{B}$ e $\mathrm{D}$ são gerados e a idéia de agradável é gerada, portanto, por dedução compara-se o que foi obtido pela comparação da lei empírica com a lei da mente de associação à lei empírica novamente e verifica-se que de fato os agentes agem no sentido de buscar o prazer porque o prazer é agradável ou o bem em si, o contrário se aplicaria para a dor, o agente pararia de agir caso a ação se associasse à dor e desta forma prova-se que uma característica da natureza humana é a tese hedonista.

Associada à tese hedonista estão as faculdades mais elevadas que geram prazeres mais elevados, prazeres que distinguem os homens dos animais, de acordo com a argumentação que vem sendo elaborada. As faculdades mais elevadas também podem ser provadas da mesma forma que a tese hedonista, de uma maneira empírica, uma vez que é a existência das faculdades mais elevadas que propicia a existência de tipos de prazeres de qualidade superior. Assim, verifica-se pela observação que os homens sentem prazeres de qualidade superior, relativamente aos animais, disto infere-se que só pode ser pela existência de faculdades mais elevadas ou estados mentais superiores que estes prazeres de qualidade superior são sentidos. 
À questão do hábito é possível aplicar um raciocínio semelhante ao raciocínio aplicado à prova da tese hedonista, pois por observação extrai-se a lei empírica de que os indivíduos agem por hábito, elevando esta lei por indução às leis mais altas, como à lei de associação tem-se que um indivíduo ao realizar uma ação A gera um hábito B e normalmente associa um prazer de curto ou de longo prazo que nem sempre é consciente, uma vez que quando se age por hábito a ação é efetuada devido à sua constância, embora o fundamento dela seja um prazer (quando gera um prazer de curto prazo podem gerar uma dor a longo prazo e pode constituir o que se denomina vício, embora não necessariamente). De qualquer forma, os indivíduos adquirem hábitos por escolherem muitas vezes realizar determinada ação. Implicitamente consideram que é a melhor forma de agir, embora nem sempre estejam corretos. Enfim, uma vez associada a constância ao hábito e o próprio prazer inconsciente, a ação é repetida, por dedução compara-se esta ação com a lei empírica e prova-se que as pessoas de fato agem por hábito.

O último elemento da natureza humana relaciona-se ao fato dos homens poderem-se transformar-se ao longo do tempo, ora este fator é extremamente simples de ser provado, uma vez que Mill assume que existem períodos dinâmicos na história para que a história se mova é necessário que o indivíduo também possa mover-se, uma vez que a sociedade é composta de indivíduos, conforme afirma, Mill:

\footnotetext{
"De fato, é minha crença que a tendência geral é $e$ continuará a ser, salvo exceções ocasionais e temporárias, uma tendência ao aperfeiçoamento, a um estado melhor $e$ mais feliz”. [Mill, 1999, p. 114]
}

À capacidade que o indivíduo tem de se transformar ao longo do tempo, também poderia ser aplicada a mesma prova que foi aplicada à tese hedonista. Considerando que o indivíduo não se transforma a cada ação, mas de tempos em tempos, suponha um espaço de tempo X. Nesse espaço de tempo X, por indução às leis mais altas, como à lei de associação, suponha que no espaço de tempo $\mathrm{X}$ a pessoa transforme uma característica de seu caráter de v para z e suponha que seja para seu benefício (porque é crença de Mill que a transformação do caráter ocorre para melhor). Caso seja para melhor, nesse período crítico, em que os arranjos sociais propiciarem circunstâncias mais 
favoráveis ou o próprio agente puder escolher circunstâncias mais favoráveis à melhora de seu caráter, então, ele continuará transformando-se até o limite de suas possibilidades. Por dedução e comparação à lei empírica de que de fato o indivíduo sofre transformações de tempos em tempos, então, prova-se também esta característica da natureza humana do indivíduo.

Como pode-se verificar o agir por hábito, as faculdades mais elevadas e a capacidade de se transformar ao longo do tempo são características do indivíduo que estão associadas à capacidade de gerar benefício ao indivíduo, por isso são denominadas subteses da tese hedonista. Contudo, todas elas podem ser denominadas leis etológicas do indivíduo, porque são as leis do meio, estão entre as leis empíricas, ou leis da observação e as leis mais abstratas ou leis da mente (leis psicológicas), segundo argumentou-se no capítulo terceiro. De acordo com Mill:

"A sucessão de estados da mente e da sociedade humanas não pode ter uma lei própria independente, mas deve, necessariamente, depender das leis psicológicas e etológicas que governam a ação das circunstâncias sobre os homens $e$ dos homens sobre as circunstâncias". [Mill, (1843), 1999, p. 114].

Assim, os elementos de uma formação mais complexa da natureza humana relativamente à natureza do indivíduo teórico de Bentham que podiam ser intuitivamente compreendidos pela análise da Autobiografia podem também ser provados pelo método dedutivo-indutivo inverso de Mill (da composição de causas de Mill), ou seja, critica-se o modelo geométrico utilizado por Bentham para construir uma natureza humana, uma vez que apenas a partir de uma característica do indivíduo tenta-se extrair diversas conseqüências morais e políticas. Mill, ao contrário, utilizando o método dedutivo inverso da física e admitindo que diversas causas explicam a natureza humana e não apenas uma, como no caso de Bentham (a tese hedonista), gerou o seguinte modelo de indivíduo: com leis da mente, com a tese hedonista (de que o indivíduo busca prazer e foge da dor), com subteses à tese hedonista de que o indivíduo possui faculdades mais elevadas que geram prazeres de qualidade mais elevados relativamente a faculdades 
menos elevadas que geram prazeres de qualidade inferior (comparados aos prazeres animais), além disso o indivíduo possui a capacidade de se transformar conforme o tempo transcorre e pode agir por hábito, por natureza.

Isto é fazer ciência; o modelo de indivíduo corresponde à natureza humana e deve ser, portanto, a base de uma arte, como ressalta Mill. Toda moralidade (uma arte que dita preceitos) deve estar ancorada em uma ciência, deve estar ancorada na natureza humana.

Da diversa natureza humana do indivíduo teórico de Mill, relativamente ao indivíduo teórico de Bentham a ciência é convertida em preceito. A tese hedonista (da natureza humana) é convertida em preceito ${ }^{442}$. Da tese hedonista de que os homens buscam o prazer e evitam a dor extrai-se o principal substrato do princípio da utilidade, pois o princípio da utilidade é o primeiro preceito que funda a moralidade utilitarista. Ele prescreve que é correto buscar a felicidade (o prazer) e errôneo buscar a dor. Contudo, a natureza humana do indivíduo teórico de Mill não é apenas tese hedonista, portanto, mais elementos precisam ser enunciados no princípio de utilidade ou primeiro princípio.

Mill apenas apresenta uma indicação de que mais elementos necessitam ser enunciados no primeiro princípio para que se compreenda a doutrina da felicidade, mais propriamente. Estes elementos derivam da natureza mais complexa do indivíduo teórico de Mill e estarão expressos nas regras morais a serem formuladas por este indivíduo e não no princípio de utilidade e é por isso que sustenta-se, nesta tese, que os outros elementos da natureza do indivíduo teórico de Mill são subteses da tese hedonista, com exceção das leis da mente que não são convertidas em preceitos, uma vez que é por elas que passa a construção de toda a ciência social.

Desta forma, o princípio de utilidade é assim formulado por Mill, conforme elencou-se em outras ocasiões desta tese:

"O credo que aceita a utilidade ou o princípio da maior felicidade como a fundação da moral sustenta que as ações são corretas na medida em que tendem a promover a felicidade e erradas conforme tendam a produzir o contrário da felicidade. Por felicidade se entende prazer e a ausência

\footnotetext{
${ }^{442}$ Mill ressalta que os princípios da ciência podem ser convertidos em preceitos da moralidade, diz que poderia ser feito através de silogismo, mas não diz como, ao menos no livro VI do Sistema de Lógica.
} 
de dor; por infelicidade, dor e a privação do prazer. Para dar uma idéia clara do padrão moral estabelecido pela teoria, é preciso dizer muito mais; trata-se de saber, em particular, o que está incluído nas idéias de dor e prazer e em que medida esse debate é uma questão aberta. Mas essas explicações suplementares não afetam a teoria da vida sobre a qual se funda a teoria da moralidade, a saber, que o prazer e a imunidade à dor são as únicas coisas desejáveis como fins, e que todas as coisas desejáveis (as quais são tão numerosas no esquema utilitarista como em qualquer outro) são desejáveis quer pelo prazer inerente a elas mesmas, quer como meios para alcançar o prazer e evitar a dor" [Mill, 1861, p.187].

Desta forma, a formulação do princípio de utilidade de Mill deixa claro que a busca pelo prazer e fuga da dor são as finalidades humanas, embora muito possa ser dito para explicar o que os homens fazem nessa busca pela felicidade. É interessante ter em vista, contudo, que aquilo que os homens fazem com vistas a atingir sua felicidade, sempre tem uma associação consciente ou inconsciente com o prazer.

Contudo, uma pergunta poderia ser feita: por que Mill deixou em aberto na própria formulação do princípio de utilidade a possibilidade de que mais elementos precisam ser esclarecidos para que se entenda ou se atinja a própria felicidade? Por que está na própria definição de moralidade o fato de que ela deve gerar regras de conduta capazes de conduzir o ser humano à felicidade, conforme é afirmação de Mill em sua definição de moralidade:

Assim, é possível definir a moralidade como as regras e os preceitos de conduta humana, cuja observação permitiria que uma existência tal como a descrita fosse assegurada, na maior medida possível, a todos os homens ${ }^{443}$ [Mill, 1861, p. 194-195].

Tendo em vista esta definição de moralidade, as características adicionais às leis da mente e à tese hedonista do indivíduo teórico de Mill derivarão

\footnotetext{
${ }^{443}$ E Mill continua dizendo que esta existência feliz deveria ser assegurada a todos os seres sescientes de criação. "e não apenas a eles, mas também, na medida em que comporte a natureza das coisas, a todos os seres sencientes da criação”[Mill, 1861, p. 195].
} 
outras regras morais além do princípio de utilidade para que este indivíduo guie-se na busca da felicidade. O método de Mill de realizar ciência social que sempre ressalta que se deve estar o mais próximo possível dos fatos e, portanto, não é aconselhável que se utilize de guia apenas o princípio de utilidade, pois ao fazer isso seria estar demasiado longe das regras práticas de ação, adicionado às novas características do indivíduo teórico de Mill relativamente ao indivíduo teórico de Bentham, gerarão princípios secundários de acordo com os quais o indivíduo age no mundo prático. Em outras palavras, o indivíduo teórico de Mill sempre age provido de regras morais, princípios secundários, relativamente ao princípio primeiro, ao princípio de utilidade.

Do agir por hábito, característica da natureza humana do indivíduo teórico de Mill adquire-se constância nas regras morais e por isso é possível agir sem efetuar um balanço entre prazer e dor a toda ação, questionando as regras do costume, conforme concluiu-se que o indivíduo teórico de Bentham faz. Ao contrário, o hábito é capaz de fazer com que os princípios secundários pareçam mais naturais aos agentes do que o primeiro princípio (o princípio de utilidade):

"Pois a moralidade gerada pelo costume (a moralidade gerada pelo hábito ${ }^{444}$ ), a que se consagram a educação e a opinião, é a única que se apresenta ao espírito com o sentimento de ser em si mesma obrigatória" [1861, p. 217].

O hábito é uma característica da natureza humana do indivíduo teórico de Mill capaz de fornecer constância às ações morais. Esse mesmo indivíduo não irá ponderar, por um cálculo entre prazer e dor se deve ou não mentir, se deve ou não roubar, matar, etc, porque agora, ele possui uma característica presente em sua natureza que permite constância às regras morais. Contudo, tais regras têm origem em um balanço passado entre prazer e dor, que uma vez estabelecido, uma vez que as pessoas ajam de acordo com este balanço inúmeras vezes e fique provado que a ação é benéfica, a ação torna-se habitual, torna-se um princípio secundário, uma regra moral que tem seu fundamento no princípio de utilidade, mas que constituem regras positivas da moral ou a

\footnotetext{
${ }^{444}$ Parêntese nosso.
} 
moral dos costumes como não roubar, não matar, não mentir, não frustrar expectativas, não ser parcial, educar os filhos, etc.

Das faculdades mais elevadas que os indivíduos possuem derivam prazeres de qualidade superior relativamente aos prazeres de qualidade inferior, relativamente aos prazeres animais, desta característica da natureza humana são convertidos os preceitos que se cultive o intelecto através do estudo e da apreciação da arte.

Da capacidade do indivíduo transformar-se ao longo do tempo, surge a possibilidade tanto do indivíduo progredir intelectualmente quanto poder cultivar motivos sociais de ação (como a simpatia pelos demais). Ou seja, esta característica da natureza humana converte alguns preceitos que se cultive o intelecto, que se cultive os assuntos públicos, que se faça um esforço para que seus interesses pessoais convirjam com os interesses coletivos, em outras palavras que se pratique o bem.

Tendo em vista a natureza humana mais complexa do indivíduo teórico de Mill relativamente ao indivíduo teórico de Bentham, o princípio de utilidade que cada um converte, dado que o princípio de utilidade ou princípio fundador da moral utilitarista é ancorado na natureza humana derivada do sistema teórico de cada autor, prova-se que há mais espaço para a formulação de uma moral positiva, com regras morais ou princípios secundários no utilitarismo de Mill, quando comparado ao utilitarismo de Bentham, precisamente porque o indivíduo teórico de Mill não realiza um cálculo entre prazer e dor a toda ação como realiza o indivíduo teórico de Bentham. As consequiências do indivíduo teórico de Bentham efetuar este cálculo entre prazer e dor a toda ação são: a) que o indivíduo torna-se um agente frio dotado de uma razão calculadora e esta razão calculadora é o principal componente na busca pela felicidade do agente e b) que o agente pondera todo tipo de ação, não há fraqueza moral na consideração pela ponderação da ação, como por exemplo, no caso de um roubo ou assassinato, característica que existe, no caso do indivíduo teórico de Mill, pois seu indivíduo é dotado do hábito. Há que se lembrar, contudo, que para Mill, também, na base de todos os princípios secundários ou regras da moralidade há um cálculo racional derivado do princípio de utilidade, ainda que esse cálculo seja um cálculo passado e que tenha se estabelecido como princípio secundário por força do hábito. 
Entre todas as regras morais ou princípios secundários ou moralidade dos costumes citadas algumas são obrigatórias, pois determinam se o indivíduo pode viver em sociedade ou não e geram direitos e deveres e outras dizem respeito a um instrumento de condução do indivíduo à felicidade e não geram direitos, nem deveres e, portanto, não são obrigatórias.

As regras morais que geram direitos e que, portanto, estão associadas às condições essenciais do bem-estar humano, em outros termos, as regras morais que são mais rigorosamente obrigatórias do que outras regras de conduta da vida são as regras que proíbem os seres humanos a prejudicarem uns aos outros (quando ocorre uma interferência injusta na liberdade) e aqui se insere as duas máximas essenciais de ação do livro A Liberdade, ancoradas no princípio de utilidade: a) "o indivíduo não é responsável perante a sociedade por suas ações, enquanto estas não afetarem os interesses de nenhum outro além dele mesmo. Conselhos, instrução, persuasão e isolamento, caso julguem necessário recorrer a este último meio para seu próprio bem, são as únicas medidas pelas quais a sociedade pode com justiça exprimir seu desagrado” [Mill, 1859, p. 143]. Esta máxima demonstra que regras morais ou preceitos podem ser gerados quando não há interações entre indivíduos, como que se aprecie a arte, que se aprimore se intelecto, etc e pode gerar uma certa sanção moral (como o Isolamento), contudo, não são regras morais que geram direitos. As regras morais que geram direitos dizem respeito à segunda máxima do livro A Liberdade de Mill, qual seja: b) Segundo, o indivíduo é responsável pelas ações prejudiciais aos interesses de outros, sujeitando-se então quer à punição social, quer à legal, se a sociedade julgar que uma ou outra seja necessária à sua proteção [Mill, 1859, p. 144]. Desta forma, regras morais como que não se deve privar alguém de sua liberdade (esta regra pode, inclusive, transformar-se em uma norma legal, aquilo que decidirá se a norma será legal ou moral, em última instância será estes princípios ou máximas secundárias da liberdade, caso a norma não possa ser mantida sob a censura ou punição da moralidade, por se tratar de um mal de grande risco para a sociedade um apelo ao primeiro princípio deve ser feito, ou um cálculo entre custo benefício, conforme enuncia Mill).

Assim, há três conjuntos de regras morais, as três dizem respeito à condução dos homens à felicidade. O conjunto que diz respeito à segunda máxima da liberdade que 
(elenca que o indivíduo é responsável perante a sociedade pelas ações prejudiciais causadas a outrem). Esse conjunto que diz respeito à segunda máxima de ação obrigatória e é determinante para verificar se um indivíduo está apto a viver em sociedade. As regras morais que se enquadram neste conjunto são que não roube, não mate, não seja parcial, não viole a propriedade de outrem, não minta, não quebre uma promessa, não frustre expectativa, não gere à ninguém o direito de querer privar-se de sua própria liberdade, não viole a liberdade de ninguém a não ser que seja necessário para impedir um mal maior $^{445}$.

O segundo conjunto de regras morais, princípios secundários relacionados à primeira máxima de liberdade que não gera direitos, nem deveres, nem tão pouco obrigações diz respeito a ações que o indivíduo gera para consigo mesmo, para seu próprio desenvolvimento, para o aprimoramento de seu caráter. Este conjunto depende do primeiro, pois prescrições como que o intelecto seja cultivado, que a arte seja apreciada terão um efeito mais positivo no caráter do indivíduo caso ele não tenha a tendência a gerar mal a outros.

Há ainda um terceiro conjunto que diz respeito às interações positivas entre indivíduos. Em outros termos os indivíduos podem gerar regras ou princípios secundários para que o bem seja feito como que motivos sociais sejam fomentados como a simpatia, o amor ao próximo, como o interesse pelo bem público, como tentar fazer convergir os interesses individuais aos interesses coletivos, como praticar a beneficência. Contudo, este conjunto de regras morais ou princípios secundários também não é obrigatório, não gera dever. Conforme afirma Mill:

\footnotetext{
"o interesse que têm em inculcar em cada um o dever de beneficência positiva é incontestável, mas num grau muito menor, pois é possível que não necessitemos dos benefícios de outros. Mas sempre necessitamos que não nos causem prejuizo. Assim, as regras morais que protegem cada indivíduo dos prejuízos que os outros possam causar-lhe, seja diretamente, seja impedindo sua liberdade de procurar o seu próprio bem, são as que lhe são mais caras"[Mill, 1861, p. 270].
}

${ }^{445}$ Mill, 1861, p.244-246. 
Independentemente desta divisão entre as regras morais que geram direitos e deveres que são as regras de justiça e as regras que não geram direitos fica provado que devido à natureza humana mais complexa do indivíduo teórico de Mill, relativamente ao indivíduo teórico de Bentham, uma vez que a ciência da natureza humana, sempre embasa a arte, os preceitos morais, há mais espaço para a formulação de regras morais no utilitarismo de Mill do que no utilitarismo de Bentham, uma vez que há espaço, no utilitarismo de Mill, conforme o próprio princípio de utilidade de Mill enuncia, para que o indivíduo aja guiado por princípios secundários ou pela moralidade dos costumes que também se modificam, mas não a cada ação, mas de época para época.

Após restar provado que há mais espaço para a moralidade no utilitarismo de Mill quando comparado ao utilitarismo de Bentham a questão que se formula é quando as regras da moral, no utilitarismo de Mill devem sair do escopo da moral e tornar-se legais?

De acordo com a segunda máxima da liberdade o indivíduo só é responsável seja legalmente, seja moralmente perante a sociedade quando causa dano a outro indivíduo, Mill não é tão assertivo quanto aos casos em que o Estado deveria ou não intervir, mas deixa claro, em A liberdade que o Estado deveria intervir o mínimo possível na liberdade dos indivíduos. Os casos em que o governo deve transformar regras morais em regras legais quando se trata de zelar para que ninguém tenha sua liberdade (de seu corpo de ir e vir a não ser que cause dano a outrem) ou propriedade violada. De acordo com Mill, o Estado deve intervir em questões como coerção à venda de bebidas em locais públicos, pois é em locais públicos que se originam crimes. O Estado deveria intervir na questão da educação de crianças, fazendo com que esta fosse estabelecida por leis, caso a criança se mostrasse incapaz de ler em determinada idade, o pai deveria pagar uma multa moderada ${ }^{446}$ e fazer com que a criança freqüentasse a escola às expensas dele. Mill apóia que o Estado possa apoiar no controle de natalidade ${ }^{447}$, quando um país estiver superpovoado. O Estado também deveria interferir em jogos de cassino tributando sua receita.

\footnotetext{
${ }^{446}$ Mill, 1859, p. 161.

447 Ibid, 163.
} 
Desta breve análise de quais seriam as regras morais que poderiam ser transformadas em legais e assim delimitar mais o escopo da moral, conclui-se que é a máxima da liberdade ou o princípio secundário da liberdade que determina se uma regra será legal ou moral. Apenas as regras morais que geram direitos e deveres, que podem gerar malefícios a outros podem tender ao campo legal, contudo, mesmo dentre estas regras, a máxima da liberdade sempre aponta para que o Estado interfira o mínimo possível na liberdade do agente. Conforme ressalta Mill:

\begin{abstract}
"Determinar o ponto em que esses males tão terríveis para a liberdade e o progresso humano começam, ou o ponto em que começam a dominar os benefícios resultantes de se aplicar coletivamente, sob chefes reconhecidos, a força da sociedade para remover obstáculos que impedem o caminho de seu bem-estar; assegurar as vantagens da centralização política e intelectual tanto quanto se possa, sem canalizar para as vias oficiais uma porção excessivamente grande da atividade geral, é uma das mais difíceis e complexas questões da arte de governar. É, em grande medida, uma questão de detalhe, na qual se devem levar em conta muitas $e$ variadas considerações, sem estabelecer nenhuma regra geral absoluta." [Mill,1861,p. 171-172]
\end{abstract}

Contudo, reconhece-se que se exista um caso em que as máximas da liberdade não possam decidir claramente sobre se a regra será moral ou legal, um apelo ao primeiro princípio, ao princípio de utilidade é perfeitamente plausível, um cálculo entre custo e benefício pode ser efetuado.

Desta forma, relembrando a ética de Bentham, ficou provado que as regras pertencentes à ética do utilitarismo de Bentham seriam àquelas que dizem respeito às ações dos indivíduos que não envolvem interações, às ações dos indivíduos que envolvem interações positivas e às ações dos indivíduos que envolvem interações negativas quando são extremamente custosas de serem transformadas em regras legais.

Contudo, viu-se que estas regras não possuíam muito significado na moralidade de Bentham, uma vez que esta moralidade era basicamente composta de um princípio, a saber: do princípio de utilidade. O indivíduo teórico de Bentham realiza uma 
avaliação das regras vigentes, da moralidade dos costumes a cada ação, devido à sua natureza, porque ele dotado de uma racionalidade calculadora como principal meio para atingir sua felicidade. Sendo assim, ele realiza um cálculo, um balanço entre prazer e dor, de acordo com o método de Bentham, a cada ação, derrubando ou mantendo as regras postas. Desta forma, é mais próprio ressaltar que há uma moralidade negativa, no sentido de que o indivíduo age no mundo prático dotado de um preceito, de uma regra, do princípio de utilidade.

De outra parte, o indivíduo teórico de Mill, por possuir uma natureza humana mais complexa, deriva um princípio de utilidade mais complexo (que ressalta como fundamento que é correto buscar o prazer e errôneo buscar a dor, mas que abre espaço para que muito mais seja dito a respeito das idéias que se faz do que é prazer e dor, para que princípios secundários sejam elaborados, ainda que não violem o preceito de busca da felicidade). Ao derivar esse princípio de utilidade mais complexo e por possuir essa natureza humana mais complexa (derivada de seu método de fazer ciências sociais), o indivíduo teórico de Mill pode agir, no mundo, dotado de princípios secundários, da moralidade dos costumes que são regras morais que em algum momento do tempo foram fundamentadas no princípio da utilidade. Há, portanto, no utilitarismo de Mill, mais espaço para a elaboração de regras morais, do que no utilitarismo de Bentham, há, propriamente, uma moral positiva, com regras morais que não são questionadas a toda ação. 


\section{Conclusão}

De acordo com tudo que foi expresso nessa tese é possível concluir que as concepções de natureza humana, tanto de Bentham quanto de Mill derivam o princípio de utilidade ou primeiro preceito da moral utilitarista e este preceito é o princípio fundador da moral utilitarista. Em outras palavras, este preceito dá origem a outras regras da moralidade.

No caso do sistema filosófico de Bentham, foi exposto que a natureza humana de seu indivíduo é uma natureza humana composta de uma razão calculadora, pois ontologicamente o que existia, para Bentham era o indivíduo, prazer e dor e este indivíduo buscava o prazer e fugia da dor. Tendo em vista a ontologia de Bentham, o modelo de indivíduo deste autor era o seguinte: a) este indivíduo busca o prazer e foge da dor, ou seja, é auto-interessado e b) o indivíduo possui a faculdade intelectual de uma razão que calcula, ele é capaz de fazer cálculos intertemporais, inclusive no que diz respeito às conseqüências das ações.

Dotado desta racionalidade calculadora o indivíduo sempre realiza complexos cálculos ao agir e é esta mesma razão o principal elemento capaz de conduzir o indivíduo à felicidade. A complexidade dos cálculos que os indivíduos efetuam ao agir (a partir de um balanço entre prazer e dor) foi mostrada no capítulo primeiro e último desta tese. Tal complexidade leva em conta a intensidade dos prazeres e dores, proximidade ou longinquidade de tais prazeres e dores e assim por diante.

A definição de ética de Bentham, a saber: Ética em geral pode ser definida como a arte de dirigir as ações humanas na produção da maior quantidade possível de felicidade da parte cujo interesse está em jogo (...)”[Bentham, 1789, p. 69] coincide com o próprio princípio de utilidade, sendo assim, ficou esclarecido, ao longo da argumentação desta tese que as normas da ética devem coincidir com o próprio princípio de utilidade, para este autor.

Portanto, a cada ação o indivíduo teórico de Bentham efetua um cálculo entre prazer e dor para verificar se as normas da moralidade, a moralidade dos costumes, estão de acordo com o princípio da utilidade, se estas normas maximizam prazer. 
Virtudes ou o bem moral existem, para este autor, conforme gerem mais prazer dor que dor, o mesmo raciocínio pode ser aplicado para os vícios. Para que a área da moralidade possa ser mais especificamente delimitada, no sistema de Bentham, as ações possíveis de serem efetuadas pelos indivíduos foram divididas em três grupos: a) o primeiro grupo diz respeito às ações que não envolvem interações entre indivíduos e quando bem efetuadas são denominadas prudência, b) o segundo grupo envolve interações que podem gerar danos entre os indivíduos e quando os agentes abstêm-se de efetuar ofensas tais atos são denominados probidade e c) o terceiro grupo envolve interações positivas entre os indivíduos, isto é, quando os indivíduos agem para ocasionar bens entre eles (é denominado beneficência).

No que diz respeito ao primeiro grupo de ações ficou decidido, por uma aplicação direta do princípio de utilidade (um cálculo entre custo benefício), que tal grupo deve ficar restrito ao âmbito da ética. Em outras palavras, são as normas da ética que devem regular as ações que não envolvem interações entre indivíduos, para Bentham. Isto ocorre, porque a tentativa de efetuar uma legislação ou punição a ações que concernem às regras da prudência podem instaurar um sentimento de perseguição dos motivos sociais como a simpatia ou amor à amizade nos membros de uma comunidade.

No que tange às ações em que indivíduos podem ocasionar mal uns aos outros, Bentham assume que este é o grande campo de atuação da legislação. Contudo, não são todos os casos que são passíveis de formulação da legislação. Em alguns casos em que a punição é dita ser não proveitosa ou não lucrativa, quando o mal da punição concorre com o mal da ofensa sem que um benefício suficiente seja auferido, um cálculo entre prazer e dor prescreve que as regras da ética sejam aplicadas (um desses casos ocorre quando motivos sedutores atuam sobre indivíduos que são extremamente sensíveis a eles. Tais indivíduos são levados a cometer o crime não importando a legislação referente ao caso). Portanto, mesmo para alguns casos em que danos podem ser causados, as regras da ética são aplicadas e não se recomenda a aplicação das regras da legislação.

Quanto à beneficência ou às regras de ação que envolvem interações positivas entre indivíduos ressalta-se que este conjunto de ações deve ficar restrito às regras da ética, uma vez que as regras de beneficência são caracterizadas pela livre disposição do agente. Em outras palavras, formular regras da legislação sobre as ações 
que envolvem interações positivas entre os agentes descaracterizaria as ações denominadas beneficentes, podendo demover a livre vontade dos indivíduos de realizar tais ações. Portanto, é um balanço entre prazer e dor que mais uma vez aponta para a não intervenção das regras da lei e atuação das regras da ética. É a razão calculadora, sob um apelo do primeiro princípio, que decide, mais uma vez, sobre a intervenção das normas da legislação ou sobre o raio de ação da ética.

Tendo estas considerações em vista, é posição de Bentham que o raio de atuação da ética é restrito ao campo da prudência, da beneficência e da probidade quando o princípio de utilidade decide ser não lucrativo ou não proveitoso formular regras da legislação.

Não obstante, resta claro que a interferência da ética é sempre feita de acordo com um apelo ao princípio de utilidade, sem o auxílio de princípios secundários, o indivíduo teórico de Bentham age no mundo prático, dotado de uma racionalidade calculadora, realizando cálculos complexos entre prazer e dor a toda ação (que leva em conta a intensidade, longinquidade, proximidade do prazer e da dor, etc). Ao realizar cálculos complexos entre prazer e dor a cada ato o indivíduo teórico de Bentham questiona toda moralidade dos costumes posta. Portanto, não há segundos princípios de acordo com os quais este indivíduo age. Este indivíduo, a cada ato, sempre realizará questionamentos, derrubando as regras dos costumes de acordo com o princípio da moralidade, reduzindo este espaço, no limite, a um princípio, a saber: ao princípio de utilidade.

A moralidade do sistema de Bentham, derivada da simples natureza humana deste indivíduo, a saber: que este indivíduo está sob o domínio de dois senhores soberanos; o prazer e a dor e busca em todos os casos maximizar o prazer e minimizar a dor, é também reduzida a um princípio, qual seja: o princípio de utilidade.

Ao contrário, o indivíduo teórico de Mill é considerado mais complexo do que o indivíduo teórico de Bentham, conforme ficou comprovado por seu método indutivo e dedutivo inverso. O modelo de indivíduo teórico de Mill possui as seguintes características, a saber: leis da mente (1. que toda impressão mental tem sua idéia, 2. leis de associação e 3. frequencia de conjunção), além disso o indivíduo possui em sua natureza a tese hedonista, ou seja, busca o prazer e evita a dor, e subteses da tese 
hedonista, como que ele possui faculdades elevadas, que ele age por hábito e que tem a capacidade de se transformar ao longo do tempo, o modelo de indivíduo teórico de Mill é dinâmico).

O fato do indivíduo possuir leis psicológicas como as leis da mente e serem extraídas por indução, é importante para provar as outras características da natureza do indivíduo teórico de Mill, especialmente a tese hedonista. Desta prova, constrói-se uma ciência da natureza humana de onde podem ser retirados ou convertidos os preceitos da arte, da moralidade.

A partir da natureza humana do indivíduo teórico de Mill, mais complexa do que a de Bentham, um princípio de utilidade também mais complexo do que o do indivíduo teórico de Bentham será construído e uma moralidade mais complexa, com a possibilidade de elaboração de mais regras, também será derivada.

O princípio de utilidade que consta no sistema de Mill trará como principal elemento a tese hedonista convertida em preceito, ou em outras palavras o fato de que se recomenda que um indivíduo deve buscar o prazer e evitar a dor, mas abre espaço para o fato de que muitas coisas precisam ser explicitadas para que se entenda o que é a busca do prazer e a fuga da dor.

É nestas muitas coisas que precisam ser expressas para explicar o prazer e dor que constam no princípio de utilidade de Mill, derivadas da natureza mais complexa deste indivíduo que se insere a possibilidade de uma moralidade com um maior número de regras. Embora todos os outros elementos da natureza humana do indivíduo teórico de Mill sejam características associadas à busca da felicidade dos indivíduos, estes elementos permitem que os agentes, no sistema de Mill, ajam no mundo prático dotados de princípios secundários. Inclusive os sentimentos dariam assentimento mais facilmente aos princípios secundários do que ao princípio primeiro, como o princípio de utilidade.

O fato do indivíduo teórico de Mill possuir em sua natureza a capacidade de agir por hábito, possibilita a não realização de cálculos a cada ação. É claro que pelo fato de Mill ser um utilitarista na base das primeiras ações está um cálculo, mas assim que o agente compreende que ações de determinado tipo são benéficas, elas tornam-se habituais e passam a figurar regras morais secundárias, embora fundamentadas no primeiro princípio. Esses princípios secundários podem ser podem ser princípios tais como: que as 
pessoas não mintam, não quebrem expectativas, não sejam parciais, não violem a liberdade de outrem (não roubem, não matem) e assim por diante.

A questão do indivíduo teórico de Mill possuir faculdades mais elevadas gera prazeres de qualidades mais elevadas, prazeres propriamente humanos que atendem concepções de vidas humanas. Essas faculdades, características da natureza humana convertem as seguintes regras ou preceitos morais: que o intelecto seja cultivado, que a arte seja apreciada, etc.

O fato do indivíduo, por natureza, poder se transformar ao longo do tempo, converte alguns preceitos morais como: que o intelecto seja cultivado, que se tome interesse nos assuntos públicos, que se faça um esforço para que seus interesses pessoais convirjam com os interesses coletivos, em outras palavras que se pratique o bem.

Dessas regras conforme argumentou-se, algumas geram direitos morais e deveres e outras são regras morais que ajudam os indivíduos na condução de sua própria felicidade e não geram deveres, nem direitos.

As regras que geram direitos dizem respeito às regras que estão de acordo com a segunda máxima de liberdade, a saber: que os indivíduos quando são capazes de gerar danos aos outros estão sujeitos à punição legal ou social (moral). Estas regras envolvem interações e podem ser comparadas às regras do agir negativo de Bentham. Contudo, no caso de Mill elas operam por meio de princípios secundários, por meio da moralidade costumeira. Então, estas regras são as regras que dizem respeito à segurança dos indivíduos, pois como atesta Mill ninguém pode passar sem segurança (que a vida de alguém não seja violada, que a propriedade de alguém não seja violada, ou em outras palavras, não roube, não mate), não seja parcial, não quebre expectativas, não minta, não quebre promessas.

O segundo conjunto de regras diz respeito à primeira máxima da liberdade que não envolve interações entre indivíduos e poderia ser comparada às regras de prudência entre os indivíduos (de Bentham). A diferença para Bentham é que estas regras derivam de características da natureza humana do indivíduo teórico de Mill (como as faculdades elevadas e a capacidade que ele tem de se transformar ao longo do tempo). A primeira máxima de liberdade diz que os indivíduos não são responsáveis perante a sociedade no que tange a padrões de seu comportamento que não envolvem outros 
indivíduos, o máximo que se pode fazer é aconselhar e até mesmo isolar tais agentes. Essas regras elencam que o intelecto seja desenvolvido, que os indivíduos apreciem a arte, que os indivíduos interessem-se pelos estudos.

O terceiro conjunto de regras envolve interações positivas entre os indivíduos e também não geram direitos nem deveres. São regras como: que os indivíduos ajudem os outros sempre que possam, sem ferir os seus interesses, ou em outras palavras, que os indivíduos façam convergir seus interesses com os interesses coletivos, que os agentes pratiquem o bem, sempre que puderem.

De todas essas regras algumas podem ser transformadas em regras legais. Foi o primeiro conjunto de regras aqui definido, no qual as pessoas podem ocasionar danos uns aos outros que representa o conjunto de onde podem ser extraídas regras legais. A segunda máxima da liberdade que apontará para o mínimo de intervenção legal possível. Somente em casos em que a moralidade não der conta do caso em questão é que se deve converter uma regra moral a uma regra da legislação. Neste caso, um apelo ao primeiro princípio pode ser necessário. Contudo, é interessante notar que a natureza humana do indivíduo teórico de Mill permite que apenas em último caso, um apelo ao primeiro princípio seja necessário como norma de ação ou de legislação. Não obstante, ser necessário ter em mente que o princípio de utilidade é o fundamento dos princípios secundários.

De todo o exposto, é possível concluir que o raciocínio de que a natureza humana (uma ciência) é a base, o fundamento de uma arte ou da moralidade que prescreve preceitos. Este modelo serve tanto para Bentham, quanto para Mill. A diferença reside no fato de que Bentham utiliza um método errôneo, na opinião de Mill para extrair a natureza humana e, portanto, embasar a arte ou o preceito da moral que é o método geométrico que não permite a composição de causas, para explicação da natureza humana. Mill ao contrário utiliza um método mais apropriado para fazer ciência, o método indutivo, dedutivo inverso concreto da física, capaz de captar outros elementos da natureza humana, como as leis da mente, faculdades elevadas, a capacidade de agir por hábito e a capacidade que o indivíduo tem de se transformar ao longo do tempo, uma ciência da natureza humana mais complexa relativamente ao indivíduo teórico de 
Bentham, capaz de embasar uma arte da moralidade também mais complexa, com mais espaço para a elaboração de regras moral conforme ficou provado. 


\section{$\underline{\text { Bibliografia }}$}

As obras de John Stuart Mill (referentes à edição da University of Toronto foram extraídas do site Liberty Fund, por isso faço menção às obras do site Liberty Fund no corpo do texto, tal referência diz respeito à edição da Universidade de Toronto):

Mill J. S (1843) A System of Logic. Edited by John M. Robson (in the University of Toronto), in 1985.

Mill J. S (1873) Autobiografia. Editado por Alexandre Braga Massella. São Paulo (Iluminuras), em 2007.

Mill J. S (1873) Autobiography. Edited by John M. Robson (in the University of Toronto), in 1985.

Mill J. S. (1824) On the Definition of Political Economy; and on the Method of Investigation proper to it. Edited by John M. Robson (in the University of Toronto), in 1985.

Mill J. S. (1835) Rationale of Representation. Edited by John M. Robson (in the University of Toronto), in 1985.

Mill J. S. (1835) Sedgwick's Discourse. Edited by John M. Robson (in the University of Toronto), in 1985.

Mill J. S. (1840) Coleridge. Edited by John M. Robson (in the University of Toronto), in 1985.

Mill J. S. (1840) Essays On Government. Edited by John M. Robson (in the University of Toronto), in 1985. 
Mill J. S. (1843) A Lógica das Ciências Morais. Iluminuras. São Paulo, 1999.

Mill J. S. (1845) An Examination on William Hamilton's Philosophy. Edited by John M. Robson (in the University of Toronto), in 1985.

Mill J. S. (1848) Principles of Political Economy. Edited by John M. Robson (in the University of Toronto), in 1985.

Mill J. S. (1850) Chapters on Socialism. Edited by John M. Robson (in the University of Toronto), in 1985.

Mill J. S. (1852) Whewell on Moral Philosophy. Edited by John M. Robson (in the University of Toronto), in 1985.

Mill J. S. (1861) Utilitarianism and On Liberty. Oxford; Ed.by Mary Warnock, 2003.

Mill J. S. (1861) Utilitarianism. Edited by John M. Robson (in the University of Toronto), in 1985.

Mill J. S. (1861) Utilitarianism. Edited by Roger Crisp. Oxford University Press. New York, 1998.

Mill J. S. (1865) Auguste Comte and Positivism. Edited by John M. Robson (in the University of Toronto), in 1985.

Mill J. S. Liberdade. Trad. de Eunice Ostrensky. Martins Fontes. São Paulo, 1999.

Mill J. S. Three Essays on Religion. Edited by John M. Robson (in the University of Toronto), in 1985.

Mill J. S. Utilitarismo. Trad. de Eunice Ostrensky. Martins Fontes. São Paulo, 1999. 
Mll J. S (1838) Bentham. Edited by John M. Robson (in the University of Toronto), in 1985. 


\section{Comentadores de John Stuart Mill:}

B. A. Balassa - Karl Marx and John Stuart Mill -John Stuart Mill Critical AssessmentsEdited by John Cunningham Wood, data.

Brown D. G. "What is Mill's Principle of Utility? Canadian Journal of Philosphy 3, 1$12,1973$.

Burtt E.-The English Philosophers From Bacon to Mill. The Modern Library. New York, $\underline{\text { data. }}$.

Capaldi N. A Biography. Cambridge University Press. Cambridge, 2004.

Chiappin J.R.N. - Racionalidade, Decisão, Solução de Problemas e o Programa de Pesquisa Racionalista. Ciência e Filosofia nº 5 p. 155-219, 1996.

Clor M. Harry Mill and Millians on Liberty and Moral Character. The Review of Politics, Vol. 47 N. 1, Jan., 1985.

Cooper, Neil , Mill's “proof” of the principle of utility. Mind 78, 278-9, 1969.

Cowling M. Mill and Liberalism. Cambridge University Press. Cambridge, 1963.

Crisp R. Routledge Philosophy Guidebook to Mill on Utilitarianism; London and New York. 1997.

Donner W. The Liberal Self. New York; Cornell University Press, 1991. 
Fagian Susan L. - Mill and Edwards on the Higher Pleasures. Cambridge University Press, Vol.58, N. 224, pp. 244-252, Apr, 1983.

Gianotti J. A. John Stuart Mill: O Psicologismo e a Fundamentação da Lógica. São Paulo, 1960.

Gibbs B. Higher and Lower Pleasures. Cambridge University Press. Vol 61, N. 235, pp. 31-59, Jan.,1986.

Hare, R. M. Moral Thinking: Its Methods, Levels, and Point; Oxford, 1981.

Heans S. J -Was Mill a Moral Scientist? . Cambridge University Press. Vol.67, N 259 pp 81-101, Jan., 1992.

Leavis F. R.: Mill on Bentham and Coleridge. Melbourne; Cambridge University Press, 1950.

Lyons, David, 'Mill's theory of morality'. Nous 10, 101-20, 1976.

Mattos V. de L. Economia política e mudança social: a filosofia econômica de John Stuart Mill, Edusp. São Paulo, 1998.

McCloskey, H, J., John Stuart Mill: A Critical Study. London and Basingstoke: Macmillan, 1971.

Millgram E., Mill's Proof of the Principle of Utility, Ethics, 282-310, CX 2000.

Paulani L. John Stuart Mill e o Estatuto do Homem Econômico. Facultad de Ciencias Económicas. Buenos Aires p. 27-32, 1999.

Raphael D.D., J.S. Mill's Proof of the Principle of Utility, Utilitas, VI p.55-63, 1994. 
Riley J. Mill's Qualitative Hedonism. The Philosophical Quartely, Vol 53, N. 212 pp. 410-418, Jul., 2003.

Robson J. M. The Improvement of Mankind: the Social and Political Thought of John Stuart Mill, University of Toronto Press. Toronto, 1968.

Rosen F. Classical Utilitarianism From Hume to Mill. Routledge, 2003.

Ryan A., The Philosophy of John Stuart Mill. Routledge Author Guides. London, 1974.

Ryberg J. Higher and Lower Pleasures: Doubts on Justification. Ethical Theory and Moral Practice. Springer. Vol. 5, N. 4 pp. 415-429, Dec. 2002.

Sen A. - Plural Utility. Blackwell Publishing, Vol. 81, N. 81 (1980 - 1981), pp. 193 215 .

Skorupski J. John Stuart Mill. London and New York. Routledge, 1989.

Skorupski J. Why Read Mill Today? London and New York. Routledge, 2006.

Ten C.L. -The Nineteenth Century. Routledge History of Philosophy. London and New York, 1994.

Urmson. The Interpretation of Moral Philosophy of John Stuart Mill. The Philosophical Quaterly, Vol 10, n 3 pp. 33-39, Jan, 1953.

West R. H. Mill's Utilitarianism. Continuum. London, 2007. 


\section{Obras de Bentham in the Works of Jeremy Bentham}

A Fragment on Government. Edinburgh: Thomess Press, 1843.

A Table of the Springs of Action. Edinburgh: Thomess Press, 1843.

An Introduction to the Principles of Moral and Legislation. Edinburgh: Thomess Press, 1843.

Anarchical Fallacies. Edinburgh: Thomess Press, 1843

Constitutional Code. Edinburgh: Thomess Press, 1843

Essay on Language. Edinburgh: Thomess Press, 1843

Essay on Logic. Edinburgh: Thomess Press, 1843

On the Liberty of the Press, and Public Discussion. Edinburgh: Thomess Press, 1843

Plan of Parliamentary Reform Bill. Edinburgh: Thomess Press, 1843

Principles of Civil Code. Edinburgh: Thomess Press, 1843

Principles of Penal Law. Edinburgh: Thomess Press, 1843

Principles of the Civil Law. Edinburgh: Thomess Press, 1843

The Books of fallacies, From Unfinished Papers. Edinburgh: Thomess Press, 1843

The Promulgation of Laws. Edinburgh: Thomess Press, 1843 
The Rationale of Reward. Edinburgh: Thomess Press, 1843

Tracts on Poor Laws and Pauper Management. Edinburgh: Thomess Press, 1843

\section{Obras de Bentham em outras edições}

Bentham's Theory of Fictions. In Ck Ogdeon. Londres: Routledge, 2000.

Déontologie, ou Science de la morale, 1834. Disponível em: http://classiques.uqac.ca/classiques/bentham_jeremy/deontologie_tome_1/deontologi e_t1.html.

Uma Introdução aos Princípios da Moral e da Legislação. São Paulo: Abril Cultural, 1974. 


\section{Comentadores de Bentham}

Bendit M. T. - The Public Interest. In Philosophy and Public Affairs, Vol. 2, No 3. (Spring, 1973), p. 291-311.

Benn A. W. - The History of English Rationalism in The Nineteenth Century. Vol I. Longmans, Greeen, And Co., 1906.

Bhikhu Parekh - Critical Assesment. "Dinwiddy J.R." - Bentham on Private Ethics and the Principle of Utility, 1993.

Broome, J. - Utility, in Economics and Philosophy, 7, 1991.Deontology and Economics, in Economics and Philosophy, 8, 1992.

Burne P.-Bentham and The Utilitarian Principle. In Mind, New Series, Vol. 58, No. 231, (Jul., 1949), p. 367-368.

Collard D. - Research on Well Being: Some Advice from Jeremy Bentham. In Wed Working 02.

Daves A. - Jeremy Bentham (1748-1832): The Utilitarian Foundations of Collectivism. Libertarian Heritage $\mathrm{n}^{\circ} 15,1995$.

Dias M. C. L. C. - Dissertação de Mestrado. São Paulo, 2007.

Drapne T. - An Introduction to Jeremy's Bentham Theory of Punishment. Journal of Bentham Studies, n5, 2002.

Fuller C. - Primeiro e mais Antigo Constitucional da Europa: Bentham's Contact with portuguese liberarls 1820-23. Journal of Bentham Studies, $\mathrm{n}^{\circ} 3$. 
Goldworth A. - Bentham's Concept of Pleasure: Its Relation to Fictitious Terms. In Ethics, Vol. 82 No 4 (Jul., 1972), 334-343.

Guidi M. E. L. - Pain and Human Action: Locke to Bentham. Journal of Bentham Studies, $n^{\circ} 3$.

James M. - Public Interest and Majority Rule in Bentham's Democratic Theory. In Political Theory, Vol 9, No 1 (Feb., 1981), p. 49-64.

Hart H.L.A. -Essays on Bentham: Studies in Jurisprudence and Political Theory. Oxford University Press, 1982.

Harworth L.- Autonomy and Utility. In Ethics, Vol. 95, No 1. (Oct., 1984), p. 5-19.

Hazlitt H. -The Foundations of Morality. Disponível em: e-text: www. hazlitt.org

Henry H. - Pleasure as the End. In The Foundations of Morality, 1964.

Hoogensen G. - Bentham's International Manuscripts Versus The Published “Works". In Journal of Bentham Studies, No 2 (2001).

McNaughton R. - A Metrical Concept of Happiness. In Philosophy and Phenomenological Research, Vol. 14, No 2. (Dec., 1953), p. 172-183.

Milo D. R. - Bentham's Principles. In Ethics Vol. 84. No 2. (Jan. 1974), p. 128-139.

Mogin P. \& Sigot N. - Halévy’s Bentham is Bentham. In Philosophy ,74 (1999).

Sidgwick H. - Bentham and Benthamism in Politics and Ethics. The Fortnightly Review, 21, January - June1877, p. 627-652. 
Singer G. M. - Actual Consequences of Utilitarianism. In Mind, New Series, Vol. 86, No. 341 (Jan., 1977), p. 67-77.

Wilson, T. - Sympathy and Self-interest, in Skinner \& Wilson (eds) The Market and the State, Oxford University Press, 1976.

Warke T. - A Reconstruction of Classical Utilitarianism. Journal of Bentham Studies, $\mathrm{n}^{\circ} 3,2000$.

Watikin P. C. - Jeremy and Samuel Bentham - The Private and the Public. Journal of Bentham Studies, n5, 2002. 


\section{Bibliografia Geral}

Aristófanes - As Nuvens. Nova Cultural. São Paulo, 1991.

Aristóteles - Arte Retórica, Arte Poética. Difusão Européia do Livro.São Paulo, 1964.

Aristotle Nicomachean Ethics. Translated and Edited by Roger Crisp. Cambridge University Press. Cambridge, 2000.

Bacon F. Novum Organum. Abril Cultural .São Paulo, 1973.

Beaver P., Africa Memoranda. Published London, 1805.

Bishop Burnet, History of my Own my Time. Oxford University Press. Oxford. 1893.

Campbell T. Poems, in Two Volumes containing Gertrude of Wyoming. London. Printed for Longman, 1810.

Cervantes S. M. de Dom Quixote de la Mancha. Revan. Rio de Janeiro, 2002.

Coleridge S. Poetical Works. Princeton University Press. Princeton, 2001.

Comte A. - Curso de Filosofia Positiva.Abril Cultural. São Paulo, 1973.

Condillac E.de Tratado das Sensações. Campinas: Editora da Universidade Estadual de Campinas, 1993.

Comte A. Discurso sobre o Espírito Positivo. Abril Cultural. 1974, São Paulo. 
Cowper W. Poems. London. Printed for Baldwin, Cradock and Joy, 1825.

Defoe D., Robson Crusoe. Penguin. London, 1965.

Demóstenes Tra.Ísis Borges da Fonseca Filípicas e a Oração sobre as questões da Queroneso.Martins Fontes. São Paulo, 2001.

Dryden-Poems. Poems by John Dryden Selected with an Introduction by Bonamy Dobrée. J. M.Dent \& Sons Limited. London, 1934.

Edgeworth M., Popular Tales. Published for J. Johnson and Cc St Paul's, 1811.

Esopo. Fábulas de Esopo. Guatemala C. A: Cholsamaj, local e data.

Falco,Vittorio de; Coimbra, Aluizio F. Os elegíacos gregos de Calino a Crates. São Paulo, 1941.

Fedro. Fábulas, Átomo. São Paulo, 2001.

Ferguson A. An Essay on the History of Civil Society. Cambridge University Press. New York, 2003.

Gibbon E. History of the Decline and Fall of the Roman Empire. Ed. David Womersley. Penguin Books. New York, 2005.

Hartley D. Observations on Man his Frame his Duty and his Expectations. London, 1834.

Homero. Ilíada. Ediouro. Rio de Janeiro, 2005. 
Homero. Odisséia III:Ítaca. Trad. Donaldo Schuler. Porto Alegre: L\&PM, 2007.

Hume D.Investigação acerca do Entendimento Humano. Abril Cultural. São Paulo, 1973.

Jarouche M. M. Livro das Mil e uma Noites. Ed. Globo. São Paulo, 2009.

Joyce J. Scientific Dialogues. London. Printed for J. Johnson, 1809.

Locke J. Ensaio acerca do Entendimento Humano. São Paulo: Abril Cultural; 1973.

M'Crie, The Life of John Knox. Ed. William Blackwood and Sons, Edinburgh 1850.

Millar, J., An Historical View of the English Government from the Settlement of the Saxon in Britain to The Revolution in 1688. Printed for J. Mawman, $\mathrm{n}^{\circ} 22$ in the Poultry. London, 1803.

Milton J. Paradise Lost. London, Methuen, 1968.

Mosheim L. J. Eclesiastical History. Published by Evert Dyckinck, Collins e Hannay, 1824

Ovidio, P. N. Metamorfoses, Cotovia. Lisboa, 2007.

Plato, Dialogues, Yale University Press, Connecticut, 1984.

Políbio. História. Ed. Universidade de Brasília, Brasília, 1985.

Reid T. An Inquiry into the Human mind on the Principles of common Sense. London, 1861. 
Robertson W. The History of America. Vol I. Principal of University of Edinburgh. Dublin.

Salústio C. C. Works. Heinemann. London, 1955.

Shakespeare W. Macbeth. Cosac Naify, São Paulo, 2009.

Sófocles. Antígona. Fundação Calouste Gulbenkian. Lisboa, 2008.

Stewart D. Philosophical Essays. First American Edition. New York, 1811.

Teócrito de S.. Antologia Bucólica. Ed. Universitária UFPB/Zarinha Centro de Cultura, João Pessoa, 2007.

Teócrito disponível em: www.Theoi.com/Text/TheocritusIdylls1.html

Thomson T. A System of Chemistry. Printed for Bell and Bradfute (etc). Edinburgh, 1804.

Tito Lucrécio Caro. Antologia de Textos de Epicuro, da Natureza. Abril Cultural. São Paulo, 1973.

Tucídides. A História da Guerra do Peloponeso: Livro I. 2. ed. Martins Fontes. São Paulo, 2008.

Virgílio. Eneida. Trad. José Victorino Barreto Feio e José Maria da Costa e Silva, Martins Fontes. São Paulo, 2004.

Virgílio. Las Bucólicas. Typographia Real. Rio de Janeiro, 1818. 
Wordsworth W. Selected Poems. Penguin. London, 1996.

Xenofonte, Cyropaedia: The Education of Cyrus, ed. Henry Graham Dakyns, Londres, 1914. 